Fvervthing

Alles

verandert altijd

Perspectieven

op literair vertalen

Lieven D'hulst en Chris Van de Poel (red.)

i.s.m. het Expertisecentrum Literair Vertalen 
ALLES VERANDERT ALTIJD 



\title{
Alles verandert altijd
}

\section{Perspectieven op literair vertalen}

\author{
Onder redactie van \\ Lieven D'hulst \& Chris Van de Poel
}


Uitgegeven met de steun van

KU Leuven Fonds voor Fair Open Access

en

Expertisecentrum Literair Vertalen (ELV), een partnerschap van de Taalunie, de KU Leuven en de Universiteit Utrecht, in samenwerking met het Nederlands Letterenfonds en het Vlaams Fonds voor de Letteren

2019 Universitaire Pers Leuven / Leuven University Press / Presses Universitaires de Louvain.

Minderbroedersstraat 4, B-300o Leuven (Belgium).

Selectie en redactie (C) Lieven D'hulst \& Chris Van de Poel, 2019.

Individuele bijdragen (C) de respectievelijke auteurs, 2019.

Dit boek is uitgegeven met de Creative Commons Attribution-NonCommercial-NoDerivatives 4.o International Public License.

\section{(c) $(1) \Theta \Theta$}

Meer details over Creative Commons licenties op http://creativecommons.org/licenses/

De referentie naar het boek moet de volgende informatie bevatten:

Lieven D'hulst en Chris Van de Poel (red.). Alles verandert altijd. Perspectieven op literair vertalen.

Leuven, Universitaire Pers Leuven. (CC BY-NC-ND 4.o International Public License)

ISBN 9789462701939 (Paperback)

ISBN 9789461662989 (e-PDF)

ISBN 9789461662996 (e-PUB)

https://doi.org/10.11116/9789461662989

$\mathrm{WD} / 2019 / 1869 / 32$

NUR: 624

Boekverzorging: Crius Group

Ontwerp omslag: Dogma 


\section{Inhoudstafel}

Woord vooraf - Lieven D’hulst \& Chris Van de Poel

\section{Deel I - Het werk in goede banen}

1.1. Literair vertaler word je, woord na woord ... - Carlo Van Baelen 11

1.2. Basiskennis en -vaardigheden - Chris Van de Poel 19

1.3. Naslag - Chris Van de Poel 29

1.4. Hoe bronteksten lezen? - Philippe Noble 39

1.5. Relatie tussen auteur en vertaler - Nicolette Hoekmeijer 47

1.6. Vertolking 2.0 - Over het opnieuw vertalen van klassiekers - Barber van de Pol $\quad 55$

1.7. Duovertalen - Niek Miedema \& Harm Damsma 63

\section{Deel II - Belangrijke begrippen}

2.1. Equivalentie in de vertaalpraktijk en de vertaalstudie - Henri Bloemen 73

2.2. Verre culturen en het vertalen van realia - Luk Van Haute 87

2.3. Vertaaltransformaties - Stella Linn 97

2.4. Creatief vertalen - Harm Damsma 105

2.5. De vertaling van meerstemmigheid en meertaligheid - Désirée Schyns 121

2.6. Humor - Jeroen Vandaele 131

2.7. Vertalen als intertekstuele praktijk - Paul Claes 143 


\section{Deel III - Een focus op genres}

3.1. Het vertalen van narratief proza - Franco Paris 153

3.2. De regels voorbij: het vertalen van poëzie - Onno Kosters 169

3.3. Enige hardop uitgesproken gedachten over het vertalen van theater - Erik Bindervoet

3.4. Denken in veelvoud: het vertalen van filosofische teksten - Jeanne Holierhoek 199

3.5. Non-fictie vertalen - Jelle Noorman 211

3.6. Vertalen van kinder- en jeugdliteratuur - Goedele De Sterck 221

\section{Deel IV - Na het vertalen}

4.1. (Zelf)revisie - Laura van Campenhout \& Ine Willems

4.2. Omgaan met promotie, prijzen en recensies - Janny MiddelbeekOortgiesen

4.3. De beoordeling van de vertaling - Fedde van Santen 


\section{Woord vooraf}

\section{Lieven D'hulst \& Chris Van de Poel}

In Alles verandert altijd. Perspectieven op literair vertalen ${ }^{1}$ worden de belangrijkste aspecten van het literair vertalen samengebracht: de zakelijke en financiële, de basiskennis en -vaardigheden die bij literair vertalen komen kijken, algemene kernbegrippen en uitdagingen, het vertalen van diverse literaire genres maar ook literaire non-fictie en filosofie, en de 'nazorg' in de vorm van revisie, marketing en promotie. Het boek is bedoeld voor zowel vertalers in opleiding als beginnende en (ver)gevorderde vertalers: kennis en de vaardigheid deze toe te passen is nooit af of volmaakt, drempels en uitdagingen die vaak tot onzekerheid en twijfel leiden, worden helder besproken. De auteurs zijn vertalers, onderzoekers en opleiders met jarenlange ervaring en uitgebreide kennis, waarmee Alles verandert altijd een uniek en veelzijdig instrument is voor iedereen die zich in de praktijk, in het vertaalonderwijs, of uit interesse bezighoudt met literair vertalen.

Kennis over vertalen, kennis van vertalen en kennis door vertalen zijn met elkaar vervlochten en complementair, zonder dat iemand zomaar over de hele variatie aan kennis beschikt. Juist die drie elementen vormen de leidraad in dit boek, waaruit vele stemmen opklinken. Die stemmen zijn ondergebracht in vier delen. Het eerste gaat over wat je moet weten en doen om je werk in goede banen te leiden: hoe zit het met contracten, subsidieregelingen, vertaalrechten? Maar ook: welke basisvaardigheden zijn het belangrijkst en hoe kun je die verder ontwikkelen? Voorts krijgt de lezer praktische adviezen aangereikt om bronteksten juist met het oog op de vertaling ervan te lezen, en gaan vertaalexperts in op de relatie met de auteur, de voor- en nadelen van duovertalingen en de omgang met reeds bestaande (al dan niet gecanoniseerde) vertalingen van de tekst. In het tweede deel wordt een begrippenapparaat besproken

1 Cf. Cees Koster, “Alles verandert altijd (en blijft ook hetzelfde): Vertaling en stijl.” Filter, 18:4 (2011), p. 3-13. 
dat belangrijke algemene kenmerken van het vertalen beschrijft (bijvoorbeeld equivalentie, realia en creativiteit). Daarnaast wordt uitvoerig ingegaan op een waaier aan procedés om gelaagde, intertekstuele en meertalige teksten om te zetten. Het derde deel focust op de drie traditionele literaire genres narratief proza, poëzie en theater, maar er zijn ook essays gewijd aan filosofische teksten, non-fictie en jeugd- en kinderliteratuur, genres die vandaag de dag nadrukkelijk aanwezig zijn in het literaire aanbod. Het laatste deel gaat in op de stadia van revisie en zelfrevisie, mogelijke bijdragen aan de promotie van de publicatie door de vertaler zelf, en aan de beoordeling van de vertaalkwaliteit door de letterenfondsen.

De bijdragen zijn van de hand van een team van deskundigen die ieder hun eigen invalshoek hanteren bij het behandelen van de gekozen topic. De bundel weerspiegelt de spreekwoordelijk geworden 'bloeiende' vertaalcultuur zoals die vandaag tot uitdrukking komt, en beoogt een dialoog tussen beginnende en door de wol geverfde vertaler tot stand te brengen. Die dialoog zal, mede in de hand gewerkt door niet te voorspellen ontwikkelingen in de literatuur, leiden tot nieuwe vertalerservaringen, voortschrijdende inzichten, aangescherpte visies. Alles verandert altijd.

Perspectieven op literair vertalen zal een bijzondere meerwaarde krijgen door het in combinatie met andere kennisinstrumenten te lezen en te gebruiken. Op de digitale kennisbank van het Expertisecentrum Literair Vertalen zijn bijvoorbeeld vele aanvullingen, verrijkingen en verdiepingen van de in de bundel besproken onderwerpen te vinden. Maar het boek is tevens het ideale naslagwerk bij cursussen, mentoraten, lezingen, vertaaldagen en andere publieksactiviteiten met hetzelfde doel: bij te dragen tot de deskundigheid van de vertaler.

De bundel is een initiatief van het Expertisecentrum Literair Vertalen (ELV; www. literairvertalen.org), dat zich ten doel stelt een impuls te geven aan de kwaliteit van het literair vertalen in en uit het Nederlands door middel van opleiding en deskundigheidsbevordering. Alles verandert altijd. Perspectieven op literair vertalen is samengesteld door Lieven D'hulst en Chris Van de Poel, beiden lid van het Wetenschappelijk Comité van het ELV. Dank is verschuldigd aan de partners van het ELV - de Taalunie, het Nederlands Letterenfonds, het Vlaams Fonds voor de Letteren, de KU Leuven en de Universiteit Utrecht - voor hun niet-aflatende interesse en steun. De samenstellers danken de Universitaire Pers Leuven voor de uitstekende begeleiding. 


\section{neal I \\ Het werk in \\ goede banen}





\section{1. \\ Literair vertaler word je, \\ woord na woord ...}

Carlo Van Baelen

De weg naar een (succesrijke) carrière als voltijds literaire vertaler is geen evidentie. Willem Elsschot wist het reeds, weliswaar in een totaal andere context: '(...) tussen droom en daad staan wetten in de weg en praktische bezwaren (...)'. Over die bindende wetten, zakelijke drempels, onverwachte kansen en institutionele realiteiten gaat deze praktijkgerichte bijdrage.

\section{Sociaal statuut}

Als literair vertaler kun je niet aan de slag in loondienst bij een uitgeverij. Het gaat om afzonderlijke opdrachten voor een specifiek vertaalwerk en wordt forfaitair en/ of proportioneel vergoed (zie verder). Je zult het statuut van zelfstandige (zzp'er) moeten aannemen. In combinatie met een andere activiteit (onderwijsopdracht, technisch vertaalwerk, loondienst, ambtenaar ...) of (mits voldoende opdrachten en zicht op continuiteit) als hoofdberoep. Dat betekent terugkerende kosten voor sociale zekerheid/volksverzekeringen, administratieve verplichtingen als ondernemer, onzekere en wisselende inkomsten, beperkte sociaalrechtelijke bescherming, noodzaak van aanvullende persoonlijke verzekeringen.

In België betaal je sociale bijdragen op basis van het bruto-inkomen. In Nederland betaal je de premie voor ziektekostenverzekering en een inkomensafhankelijke bijdrage zorgverzekering. Voor bijkomende pensioenrechten moet je je aanvullend verzekeren.

Je kunt je vertaalactiviteiten onderbrengen in een vennootschap, wat gezien de beperkte investeringen en het lage kapitaals- en debiteurenrisico geen prioriteit is. De verplichte boekhouding, uitgebreide juridische procedures en extra kosten zijn 
overgedimensioneerd voor de zelfstandige activiteit van een vertaler. Informeer je grondig van bij de start en vermijd boetes, overmoed en rechtsonzekerheid. ${ }^{2}$

\section{Je bent auteur}

Juridisch is je vertaling een 'auteurswerk'. Voorwaarden daarvoor zijn: originele creatie - met persoonlijke stempel - in een concrete vorm. Het auteursrecht ontstaat van rechtswege, vereist geen formaliteiten en geldt tot zeventig jaar na overlijden van de auteur. Dat betekent dat jij alleen kunt beschikken over de morele (bekendmaking, erkenning als auteur, integriteit) en zakelijke rechten (reproductierecht, publieke mededeling) van je werk. Die laatste rechten zijn overdraagbaar, enkel mits een geschreven overeenkomst waarin de rechten en plichten van beide partijen - vertaler en opdrachtgever/uitgever - bepaald worden.

Een Modelcontract Literaire Vertalingen opgemaakt door de Nederlandse Auteursbond ${ }^{3}$ en de GAU (Groep Algemene Uitgeverijen) biedt een evenwichtig kader daarvoor. Een gelijkaardige standaardovereenkomst is in Vlaanderen in voorbereiding. De financiële voorwaarden maken deel uit van een onderhandeling; een redelijk en gangbaar (minimaal) woordtarief ${ }^{4}$ geldt als sectorgebruik en wordt als subsidievoorwaarde gesteld door de beide Letterenfondsen.

Wat hoort wel/niet in een uitgavecontract?

WEL:

- contracterende partijen: uitgeverij (wie tekent namens de uitgeverij?), vertaler

- $\quad$ auteur en oorspronkelijke titel; Nederlandstalige (werk)titel

- verloning: woordtarief, royaltyregeling

- geschatte omvang (woorden of standaardpagina's)

- oplage eerste druk

2 In Vlaanderen kun je terecht bij het Cultuurloket: www.cultuurloket.be: brochures kunstenaarsstatuut / zelfstandige in bijberoep. FOD Economie: www.economie.fgov.be: brochure Zelfstandige worden. Voor Nederland: www.ikwordzzper.nl.

3 Auteursbond: https://literairvertalers.auteursbond.nl

4 Voor 2019: 6,6 cent per woord voor proza en non-fictie, voor poëzie 2,29 euro per regel met een minimum van 40,19 euro per gedicht. Vanaf 2500/500o verkochte exemplaren, voor pockets, speciale edities, enz. geldt een aanvullend royaltypercentage variërend van 2 tot 5 procent. 
- inleverdatum, inlevervorm

- afspraak betreffende drukproef: aflevering - timing voor correcties - wat kan niet?

- naamsvermelding vertaler in colofon, op titelpagina, in aanbiedingsfolder, op advertenties en promotiemateriaal

- aantal gratis auteursexemplaren, ook bij herdruk en speciale uitgaven

- tijdige informatie over prijsopheffing en verramsjen

- jaarlijkse opgave van verkochte aantallen en stock

- exploitatievoorwaarden als e-boek, luisterboek, streamingabonnement

- afspraken over naburige rechten (bewerking, opnemen in bloemlezing, uitgebreide citaten ...)

NIET:

- participatie in redactie-, productie- of promotiekosten

- verplichte afname

- ontbreken van een publicatiedatum

- gratis lezingen

- overdracht van leenrecht, reprografierecht

- eenzijdig schrappen of te ruime redactionele ingrepen zonder overleg

\section{Inkomstenbronnen en belastingen}

In principe vormen de forfaitaire vertaalvergoedingen en eventuele royalty's de basis van jouw inkomen. Die inkomsten vormen de basis voor je sociale bijdragen/volksverzekeringen en voor je belasting op inkomsten uit vertaalwerk. Berekeningsbasis zijn de bruto-inkomsten na aftrek van beroepskosten.

In Nederland wordt de winst uit onderneming (= omzet minus bedrijfskosten) na aftrek van relevante aftrekposten (zelfstandigenaftrek, startersaftrek, oudedagreserve ...) belast volgens progressieve schijven. Aanvullend kunnen dividendinkomsten en vermogen belast worden. Gezien de omvangrijke belastingwetgeving is de samenwerking met een accountant of fiscaal adviseur aangewezen.

In België geldt een specifieke regeling voor ingezetenen met inkomsten uit auteursrechten die uitbetaald worden aan natuurlijke personen; die worden belast als roerende inkomsten na forfaitaire kostenaftrek. De Belgische betalingsplichtige (de uitgever meestal) dient de inhouding en doorstorting van de roerende voorheffing 
te doen. Voor een buitenlandse betalingsplichtige - bijvoorbeeld een Nederlandse uitgeverij - geldt dit niet, het is aan de vertaler om dit in zijn belastingaangifte correct op te nemen. In de praktijk wordt een deel van de vertaalvergoeding gekwalificeerd als prestatievergoeding (beroepsinkomsten), een deel als auteursrechtenvergoeding. ${ }^{5}$

Inkomsten uit aanvullende activiteiten als literair vertaler ${ }^{6}$ - lezingen, workshops, redactiewerk, recensies ... - worden beschouwd als beroepsinkomsten en als zodanig belast. Voor bepaalde prestaties is de BTW van toepassing.

Je literair statuut als auteur biedt mogelijkheden als aanbieder van lezingen over vertalen als volwaardige literaire activiteit, over vertaalde werken en auteurs, over de cultuur en het literaire leven in het taalgebied van jouw brontaal, over valkuilen en keuzes bij het vertalen. Daarnaast kun je je schrijf- en taalcompetenties inzetten voor redactiewerk, ghostwriting, journalistieke opdrachten, vertaalwerk voor media ... Deze inkomsten worden gekwalificeerd als beroepsinkomsten en als zodanig belast.

Als vertaler heb je ook recht op een reprografievergoeding voor gekopieerde teksten en leenrechtvergoeding voor via de openbare bibliotheken geleende werken. Deze collectieve rechten worden uitgekeerd via de beheersvennootschap Reprobel (België) $)^{7}$ en Lira (Nederland) ${ }^{8}$. Voor Belgische ingezetenen is aansluiting bij een beheersvennootschap als lid noodzakelijk: de Belgische rechten worden niet automatisch uitbetaald aan de rechthebbenden; in Nederland verworven rechten worden rechtstreeks aan Vlaamse vertalers uitbetaald door Lira. Nederlandse vertalers ontvangen hun in België verworven rechten via Lira.

\section{Subsidies Nederlands als doeltaal}

Het grote aandeel van vertalingen in het Nederlands in de Nederlandse en Vlaamse boekenmarkt, de openheid voor culturele import en de waardering voor kwaliteitsvol vertaalwerk vertalen zich in gerichte subsidieregelingen voor literaire vertalers en vertalingen. Het arbeidsintensieve vertaalwerk biedt immers aan de gangbare woordvergoeding onvoldoende inkomsten om te (over)leven. Wegens de culturele en literaire meerwaarde van vertalingen bieden de Vlaamse en Nederlandse overheden

5 Meer informatie op de website van de Vlaamse Auteursvereniging (VAV): https://www.auteursvereniging.be/. Voor Nederland: https://www.belastingdienst.nl/, handboek ondernemen.

6 Zie ook hoofdstuk 4.2.

7 Zie op de website van Reprobel: https://www.reprobel.be/.

8 Zie website Lira: www.lira.nl. 
via de Letterenfondsen subsidies om kwaliteitsvol vertaalwerk ${ }^{9}$ mogelijk te maken en te stimuleren. Voorwaarden zijn positief beoordeelde, als boek verschenen eerdere literaire vertalingen, een concreet literair vertaalproject op basis van een vertaalcontract dat de gangbare woordvergoeding garandeert, een proefvertaling en uittreksels uit de literaire brontekst.

Om de carrièrestart van beginnende vertalers te ondersteunen zijn er voor hen specifieke regelingen. De stimuleringssubsidie moet de vertaler de financiële slagkracht en extra motivatie geven om zich verder te bekwamen in het vak van het literair vertalen en zo zijn positie op de literaire uitgeversmarkt te versterken. ${ }^{10}$

Specifiek voor startende literaire vertalers biedt het ELV ontwikkelingsbeurzen aan veelbelovende literair vertalers om onder begeleiding van een ervaren collega verder te professionaliseren. De regeling is bestemd voor beginnende literair vertalers die een cursus bij het ELV of een vergelijkbare opleiding hebben gevolgd.

Sommige buitenlandse Fondsen of overheidsorganisaties ${ }^{11}$ stimuleren vertalingen van literair werk van eigen bodem door vertaal- en/of productiesubsidies toe te kennen. Die zijn bedoeld voor Nederlandse en Vlaamse uitgevers om de financiële drempel voor een vertaling (een risicovolle vaste kost) te verlagen. Dit is geen subsidie voor de vertaler rechtstreeks, maar maakt wel een positieve uitgavebeslissing mee mogelijk en kan dus tot een vertaalopdracht leiden. Buitenlandse uitgevers zijn op de hoogte van deze regelingen en meer informatie over deze subsidieregelingen is ook terug te vinden op de websites van de Letterenfondsen.

\section{Subsidies Nederlands als brontaal}

Op hun beurt kennen de Letterenfondsen in Vlaanderen en Nederland vertaal- en productiesubsidies toe voor vertalingen van gepubliceerd oorspronkelijk Nederlandstalig werk. Ook hier gelden kwaliteitsoordelen, zowel betreffende het oorspronkelijk werk, betreffende de buitenlandse uitgever als omtrent de vertaler. Op de websites

9 Zie ook hoofdstuk 4.3.

10 Zie voor details de website van het VFL: http://www.fondsvoordeletteren.be/ (subsidies, vertalers) - voor Nederland http://www.letterenfonds.nl/nl/ (literaire vertalingen).

11

ENLIT: European Network for Literary Translation is een samenwerkingsverband van Europese culturele instellingen voor de promotie van literatuur en vertalingen bij uitgevers, auteurs, vertalers en literaire organisaties. Voor deelnemende landen en organisaties zie https://publishingperspectives. com/2016/11/enlit-european-network-literary-translation-launched-frankfurt/. 
kun je toekenningen uit het verleden terugvinden, een actueel overzicht van de aan het buitenland gepresenteerde werken voor vertaling en de data van de buitenlandse rechtenbeurzen waar de Fondsen aanwezig zijn. Voor de buitenlandse uitgever kunnen deze subsidieregelingen extra elementen voor een positieve uitgavebeslissing vormen.

\section{Literair vertaler word je}

Ervaren vertalers hebben het graag over (vertaal)kilometers maken. Niet als uithoudingsproef, maar als noodzakelijke ervaringsopbouw. Aanbevolen instap zijn korte deelvertalingen voor literaire tijdschriften, duovertalingen met een ervaren collega, niet te complexe teksten om ondersteund door workshops en bijscholingen het moeilijkere werk aan te pakken.

Vertaalopdrachten vallen zelden uit de lucht. Een kwaliteitsvol vertalerscurriculum is nodig voor wie bij een uitgever wil solliciteren, waarbij een introductie door een ervaren vertaler een extra opstap biedt. Uitgevers staan open voor suggesties voor vertalingen van buitenlandse titels, ${ }^{12}$ maar realiseer je dat hun eerste criterium verkoopbaarheid is - welk uniek verhaal dat potentiële lezers kan aanspreken, zit er achter jouw voorstel? Verkoopcijfers, positieve recensies in relevante buitenlandse media, reeds beschikbare vertalingen in andere talen, referenties naar theater-, film- en tv-bewerkingen, sociale mediaverwijzingen kunnen belangrijke argumenten vormen. Met een synopsis en een proeve van een fragment van jouw vertaling als overtuigende onderlegger.

Solliciteer gericht: analyseer de uitgaven van een uitgeefhuis of imprint om te beoordelen of jouw voorstel aansluit bij het profiel van het literaire fonds: literair niveau, specifiek poëzie of essay, vergelijkbare auteurs en titels, taal- of landenaccenten, boekverzorging, redactionele begeleiding, lezersprofielen en aangesproken leeftijdsgroepen, meer gericht op klassiekers, gevestigde waarden of experimentele werken ... 


\section{De economische realiteit}

De boekenmarkt wordt gestuurd vanuit een economische logica: uitgeverijen en boekhandels zijn ondernemingen die een minimaal rendement moeten realiseren om te blijven bestaan. Literaire en culturele overwegingen spelen zeker mee in de selectie van titels door de uitgever en de boekhandel - dat is immers de aantrekkingskracht en motivatie voor velen die werken in de boekensector - maar steeds in het zorgvuldig zoeken naar een noodzakelijk evenwicht met economische overwegingen die de investeringsruimte beperken. Literaire pareltjes die wellicht slechts een klein publiek zullen aanspreken worden niet uitgebracht of komen niet op de boekhandelsplanken terecht. Uiteindelijk is het de lezer/koper die bepaalt of experiment mogelijk blijft.

De boekenmarkt staat in beide landen onder druk door een dalende vraag. Jaarlijks verschijnen er ruim 25.000 nieuwe titels ${ }^{13}$ in Vlaanderen en Nederland, bijna elke twintig minuten een nieuw boek, 24/7. Het totale aanbod aan Nederlandstalige titels is ruim 100.00o. Fictie voor volwassenen is in Vlaanderen met een marktaandeel van ruim 26 procent het belangrijkste segment, in Nederland is het aandeel van fictie 40 procent. Er verschijnen meer nieuwe vertaalde fictietitels dan oorspronkelijk Nederlandse fictie. Voor thrillers en spannende boeken is dit zelfs 1 op 2 nieuwe titels. Poëzie wordt amper vertaald: slechts 2,5 procent vertalingen op het totale nieuwe aanbod aan dichtbundels. Engels is de dominante brontaal van waaruit vertaald wordt (ruim 6o procent), gevolgd door Frans (ca. 15 procent) en Duits (ruim 1o procent). Meest vertaald zijn strips, gevolgd door fictie en literaire non-fictie, en minder dan gemiddeld non-fictie vrije tijd en kinderboeken.

De 100 bestverkochte titels maken ruim een kwart uit van de totale boekenmarkt van publieksboeken. Het aandeel van deze top 100-titels blijft stijgen, wat wijst op een versterking van het bestsellereffect. Ongeveer 13.500 auteurs hebben in de voorbije vijf jaar een boek op de markt gebracht. In diezelfde periode realiseerden 1880 vertalers een nieuwe titel in het literair-culturele segment. 


\section{Structurele ondersteuning}

In het Nederlandstalige taalgebied zijn vertalingen in het Nederlands goed voor 20 procent van het nieuwe titelaanbod en is 1 op 2 van de top 50 een vertaald boek. Ter vergelijking: in het Angelsaksisch taalgebied is slechts 2 procent van de nieuwe titelproductie een vertaling.

Deze belangrijke marktfactor vertaalt zich in een sterke positie van vertalingen en vertalers in de gezamenlijke boekensector: in de auteursverenigingen waarin de secties vertalers een gelijkwaardige plaats innemen; in de breed uitgebouwde subsidieregelingen van de Letterenfondsen voor pre-starters tot gevestigde vertalers; in het gezamenlijk Modelcontract van vertalers en uitgevers; een ruim aanbod aan vorming en bijscholing: een binationale masteropleiding, Vertalersvakschool, workshops en mentoraten; het Expertisecentrum Literair Vertalen; het actieve vertaalbeleid door de Letterenfondsen met het Nederlands als brontaal op buitenlandse vakbeurzen, bij uitgevers, in samenwerking met buitenlandse vertalers; faciliteiten voor buitenlandse vertalers in de Vertalershuizen in Amsterdam en Antwerpen; topseminaries en intensieve workshops voor vertalers uit het Nederlands; uitgevers met oog voor wat er bij buitenlandse collega's verschijnt ...

Een bevoorrechte positie voor vertalers in vergelijking met het buitenland. Wat niet betekent dat er geen strijdpunten meer zijn. Als vertaler moet je alert blijven en blijven groeien ... 


\title{
1.2. \\ Basiskennis en -vaardigheden
}

\author{
Chris Van de Poel
}

Over welke basiskennis en -vaardigheden moet de beginnende vertaler beschikken? Sinds de publicatie van het Petra-E Framework, het Europees referentiekader voor de opleiding en deskundigheidsbevordering van literair vertalers (Petra-E Network 2016-2017), beschikken we over een model dat een overzicht biedt van de 'kennis, vaardigheden en attitudes' die van een literair vertaler verwacht kunnen worden, die hem in hun samenhang tot een 'competent' literair vertaler maken.' Het competentiegerichte model, een analytisch model, onderscheidt en definieert daarbij acht deelcompetenties die de competentie van de vertaler (mede) bepalen, zonder onderlinge hiërarchie: transfercompetentie; talige competentie; tekstuele competentie; heuristische competentie; literair-culturele competentie; professionele competentie; evaluatieve competentie; onderzoekscompetentie. Die deelcompetenties worden ieder afzonderlijk beschreven aan de hand van descriptoren, die samen een zo volledig mogelijke definitie van de deelcompetentie vormen. Het competentiemodel omvat bovendien een leerlijn, met vijf competentieniveaus: beginner, gevorderde, beginnend professional, professional en expert. De descriptoren per niveau (waar relevant) drukken uit wat een vertaler op een bepaald niveau zou moeten kennen en kunnen en geven dus, lineair, de voortschrijdende competentieverwerving weer.

In het onderhavige hoofdstuk wordt het referentiekader 'oriënterend' gehanteerd, namelijk ter bespreking van wat een literair vertaler in opleiding (beginner en gevorderde) moet kennen en kunnen. Wat moet hij als beginnend professional verworven hebben om tegen zijn taak opgewassen te zijn, om zich te kunnen handhaven te midden van andere professionals en om zich verder te kunnen ontwikkelen? Daarbij wordt uitgegaan van de enigszins kunstmatige lineaire voorstelling van het proces

$1 \quad$ Zie ook hoofdstuk 1.3. 
dat loopt van vertaalopdracht tot de aflevering van de vertaling, hoewel dat proces evenzeer gekenmerkt wordt door circulariteit en gelijktijdige toepassing van kennis en vaardigheden.

\section{De vertaler: een meervoudig lezer en kenner van brontaal, -literatuur en -cultuur}

Geen goed vertaler zonder een goed lezer te zijn. Het mag dan al een open deur heten, in de huidige tijd, waarin snelheid alom en niet het minst in de boekensector steeds meer een doorslaggevende factor is, kan de tijd die de vertaler wijdt aan (of 'investeert in', want ja, 'het betaalt zich terug') het lezen en doorgronden van de tekst niet voldoende benadrukt worden als voorwaarde voor een deugdelijke vertaling. De literair vertaler is daarbij onvermijdelijk een meervoudig lezer, mogelijk zelfs in de hierna gehanteerde volgorde: hij stelt zich zo goed mogelijk in de positie van de gewone lezer, de brontaallezer, op zoek naar de leeservaring van de door de auteur beoogde lezer en de effecten van de tekst op die lezer, emotioneel, zintuiglijk, mentaal, psychologisch (spanning) et cetera; ook leest hij als een literair geoefend en gevormd lezer, als een 'letterkundige' in de ruime zin van het woord (geleerd maar ook belezen); hij leest bovendien als een vertaalkundige en intercultureel deskundige, vanuit het besef dat hij de tekst moet overbrengen in de taal van de nieuwe lezer, dat de tekst zijn lezers moet vinden en zijn plaats moet verwerven in de doelcultuur; ten slotte, maar in een veel later stadium, zal hij de rol van eerste lezer van de eigen vertaling op zich nemen, een wijze van lezen waarop aan het eind van dit hoofdstuk nader ingegaan wordt.

Om te komen tot een goed begrip van de brontekst zijn verschillende competenties vereist, te beginnen met de talige competentie. De vertaler moet een behoorlijk gevorderde (al is het dan deels passieve) kennis van de brontaal - grammaticaal, stilistisch en pragmatisch - hebben en geoefend zijn in het lezen van teksten in die taal. Hij moet voldoende vertrouwd zijn met haar (al dan niet periodegebonden) idiomatische uitdrukkingsvormen, haar taalvariatie (regionale of sociale varianten, vaktalen, registers etc.), haar literaire taal en stijlen. Een literaire tekst staat immers open voor alles. Bij het analyseren van de brontekst wordt ook de tekstuele competentie belangrijk: de kennis van taal- en stijlmiddelen, van taal- en stijlvariatie in de brontaal dient in verband te worden gebracht met de kennis van de literaire genres, stijlen, bijbehorende technieken en repertoire. Zo kunnen de betekenis, 
functie, relevantie van het opvoeren van een bepaald personage, van bepaalde omgevingsbeelden, van een specifiek registergebruik, van een specifieke toon, van zekere sfeer- of stemmingselementen et cetera heel anders zijn binnen de context van poëtische, dramatische of narratieve teksten, van een gedicht of een roman, van een hedendaagse of een negentiende-eeuwse tekst, van een romantische of postmoderne tekst. Hiermee wordt ook de literair-culturele competentie van de vertaler aangesproken: ${ }^{2}$ zijn kennis van literaire en culturele verschijnselen, verschijningsvormen, tradities en hun plaats binnen de broncultuur; zijn vertrouwdheid met broncultuur-specifieke elementen en verwijzingen zoals aanduidingen voor realia, maar evengoed de verschillen in associatieve werking of effect van bepaalde wél gemeenschappelijke elementen (bijvoorbeeld koude, zuinigheid, dinsdag de dertiende, een 'laat avondmaal' in een Spaanse versus een Nederlandse context), verwijzingen naar of allusies op het (cultuurhistorische, talige, literaire ...) erfgoed of de buitentekstuele context.

\section{Het zoeken en kritisch gebruiken van (analoog en digitaal) referentiemateriaal}

Het mag intussen duidelijk zijn dat bij elke nieuwe vertaalopdracht de kennis en vaardigheden van de vertaler op de proef worden gesteld en dat die vaker niet dan wel geheel toereikend zullen blijken. Om het inzicht in de brontekst te vergroten moet hij dus in staat zijn strategisch op zoek te gaan naar en kritisch gebruik te maken van al dan niet digitale informatiebronnen, naslagwerken en ander documentatiemateriaal, talig en thematisch. ${ }^{3}$ Ook niet-digitale informatiebronnen zijn vandaag vaak het snelst op het spoor te komen door te zoeken op het internet: met gebruikmaking van zoekmotoren, portaalsites, databanken, elektronische catalogi et cetera. Digitale zoekvaardigheid (tot op heden menig literair vertaler in het Nederlandse taalgebied bijgebracht door taalhistoricus en -journalist Ewoud Sanders), de kritische omgang met zoekresultaten en de juiste balans tussen online en traditioneel zoeken vallen, naast andere digitale vaardigheden (zoals het goede beheer en het efficiënte gebruik van data en bronnen), onder de digitale geletterdheid, die stilaan een vast onderdeel vormt van de studieprogramma's voor studenten letteren en studenten vertalen.

2 Zie ook 2.2.

3 Zie ook 1.3. 
Tot dezelfde heuristische competentie behoort het oordeelkundig hanteren van verschillende edities van een tekst en het benutten van het kritisch apparaat. Bij overlevering van oudere teksten op basis van onbetrouwbare of niet-geautoriseerde uitgaven (maar evengoed voor de poëzie van Richard Minne, voor de Max Havelaar van Multatuli of voor Het Achterhuis van Anne Frank), komt het erop aan om - indien voorhanden - kritische of wetenschappelijk ondersteunde edities te lokaliseren.

\section{Blijken van professionaliteit}

$\mathrm{Bij}$ al dat zoeken en raadplegen van naslagwerken en documentatiemateriaal, het virtueel of reëel bezoeken van musea, archieven, monumenten, geografische plekken of alles wat enige relevantie heeft voor het beter begrip van de tekst, mag de vertaler, hoe vormend of verrijkend dat proces ook mag zijn, uiteraard de beschikbare tijd niet uit het oog verliezen: de deadlines voor literaire opdrachten mogen zich dan algauw in maanden of ook weleens jaren laten uitdrukken, efficiëntie bij het plannen van de werkzaamheden is daarom niet minder cruciaal. Het respecteren van de deadlines behoort tot de professionele basisvaardigheden en -attitude van de literair vertaler, die beter dan wie ook weet dat uitgevers en redacteuren werken op basis van strakke productieschema's. Dat neemt niet weg dat de inschatting van de tijd die de vertaling vergt een enkele keer verkeerd kan blijken. In dat geval is het belangrijk zich professioneel te betonen door hierover tijdig op open wijze te communiceren en zich bij het zoeken naar een oplossing coöperatief op te stellen - een kwestie van professionaliteit maar ook van beroepsethiek.

\section{Deskundigheid in het identificeren en oplossen van vertaalproblemen}

Wanneer een ervaren vertaler zich documenteert, weet hij zich te beperken, niet alleen omdat hij een waakzaam oog houdt op zijn planning, maar ook omdat hij erin geoefend is om zich reeds in de voorbereidende fase van tekstbegrip en analyse te richten op elementen of aspecten van de tekst die een belemmerende factor zullen vormen bij de overgang naar de andere taal en cultuur. Relevantie voor de vertaling vormt de maatstaf om die problemen te identificeren en uit te diepen. Christiane Nord hanteert daarbij vier categorieën (Nord 2010: 147): buitentekstueel bepaalde 
pragmatische vertaalproblemen, voortkomende uit de verandering van communicatieve situatie (zoals de andere plaats, tijd, voorkennis van de doeltaallezer), en cultuurgebonden problemen (andere normen en conventies, zoals genreconventies, beleefdheidsconventies, maateenheden); voorts binnentekstuele problemen die specifiek zijn voor de overgang van de bron- naar de doeltaal (bijv. de vertaling van het Spaanse gerundium in het Nederlands), voortkomende uit de structuurverschillen tussen de twee talen, en tekstspecifieke problemen (kenmerken of elementen eigen aan een individuele tekst).

Die vroegtijdige aandacht voor vertaalproblemen maakt de vertaler tot de professional tussen twee talen en culturen, die als kernactiviteit en belangrijkste zorg heeft de afstand, tegenstellingen en verschillen tussen de twee te overbruggen, niet op zich, maar altijd in rechtstreeks verband met of dienstbaar aan de literaire tekst. ${ }^{4}$ In gevallen waarin het hem ontbreekt aan vertaalkundige kennis van of ervaring met een bepaalde vertaalproblematiek zal hij - andermaal - zoekkanalen of bronnen moeten benutten zodat hij een beeld kan krijgen van beproefde strategieën en procedés. Legio voorbeelden zijn er te noemen van problemen die zich bij de overgang van de ene taal naar de andere, de ene cultuur naar de andere kunnen voordoen en die de volle aandacht van de vertaler verdienen: de beleefdheidsvorm waarin Franse geliefden elkaar zelfs op de meest intieme momenten aanspreken; de kortaffe imperatiefvorm die in het Spaans in de dagelijkse (ook vriendelijke) omgang wordt gebruikt; specifieke plekken (wijken, straten, restaurants) die in de brontekst genoemd worden tot nadere karakterisering van een personage; beeldspraak of symboliek uit een semantisch veld dat niet of niet even uitgebreid voorkomt in de doeltaal of -cultuur of niet met hetzelfde effect (op basis van associaties of connotaties) in te zetten is in de doeltaal; topoi die de hedendaagse doeltaallezer niet meer vertrouwd zijn; de achterbuurtentaal uit een negentiende-eeuwse realistische of naturalistische roman; meertaligheid in een hedendaagse Amerikaanse migrantenroman, met een voor de doeltekst onmogelijke combinatie van talen et cetera. In deze fase van de transfer kijkt de vertaler dus reeds vooruit in de richting van de nieuwe literaire tekst, lezer, cultuur en context. Met kennis van verschillende vertaalopvattingen, -strategieën en procedés aangaande specifieke problemen en in staat om de implicaties voor de te vertalen tekst te overzien, gaat hij over tot gepaste en weloverwogen oplossingen. Hoe vaardiger en meer ervaren, des te gemakkelijker zal hij, buiten de verworven technieken en procedés om, vindingrijkheid en creativiteit aan de dag weten te leggen bij het zoeken van oplossingen. 


\section{Goed thuis in de doeltaal, -literatuur, -cultuur}

Ten slotte moet de doeltekst tot stand gebracht of geschreven worden - voor zover de vertaler daarmee niet al een begin heeft gemaakt in de vorige stadia. Dat vereist een beheersingsniveau in de doeltaal dat overeenstemt met het hoogste niveau uit het Europese Referentiekader (ERK) (Nederlandse Taalunie 2008), niveau C2: op dat niveau is men bij het schrijven in het algemeen (bij het creatief schrijven in het bijzonder) in staat heldere, soepele, complexe teksten (creatief schrijven: ten volle boeiende verhalen en beschrijvingen van ervaringen) te schrijven, in een gepaste en doelmatige stijl (creatief schrijven: afgestemd op het gekozen genre) en met een doeltreffende logische structuur. Hoewel precisering voor het bemiddelende schrijven dat het literair vertalen is, kennelijk nog ontbreekt in het ERK, mag men aannemen dat voor die vorm van schrijven op zijn minst dezelfde eisen gelden met betrekking tot de doeltaal: een brede lexicale kennis, met inbegrip van idiomatische, spreektalige uitdrukkingen en connotaties; trefzekerheid in de woordkeuze en het vermogen ideeën op uiteenlopende wijzen te formuleren om betekenisnuances of nadruk aan te brengen en dubbelzinnigheid te vermijden; de bekwaamheid om, ook met een zekere graad van complexiteit, grammaticaal correct en samenhangend te schrijven, met kennis van de spelling- en interpunctieregels; het besef van sociolinguïstische (situatie- en groepsgebonden variatie) en sociaal-culturele implicaties van het taalgebruik in de doeltaal; tot slot, de kennis en vaardigheid om gebruik te maken van digitale of andere naslagwerken ter ondersteuning van het schrijven.

Bij het literair vertalen wordt in de regel in de moedertaal vertaald, vanwege het vereiste taalniveau in combinatie met al die andere voorwaarden verbonden met doeltaal en -literatuur: de beheersing van de literaire taal en van een veelheid aan taalvarianten en literaire stijlen; de uitgebreide kennis van de literaire genres en genretradities, teksttypen, literaire technieken; het vermogen tot trefzekere creatieve oplossingen en keuzes. Ook een verregaande vertrouwdheid met de doelcultuur is cruciaal, niet het minst om het effect van bepaalde keuzes op de nieuwe lezer in te kunnen schatten: over welke kennis beschikt hij, welke normen en waarden hanteert hij, welke gevoeligheden vertoont hij, welke literaire bagage heeft hij, welke procedés zijn hem, in welke mate, vertrouwd, in hoeverre staat hij open voor vernieuwende of creatieve procedés of inhouden et cetera? Ook in dit stadium wordt de literair-culturele competentie van de vertaler dus op de proef gesteld, zodra een cultuurspecifiek element, een intertekstuele verwijzing, contextgebonden verschijnselen of gewoonten in een tekst opduiken, maar ditmaal doelpoolgericht. 


\section{Vertaaltechnische vorming}

Een ander aspect dat het bemiddelend schrijven onderscheidt van het autonome schrijven bleef nog onbesproken, hoewel het een van de grootste uitdagingen vormt bij het vertalen: de vertaler moet zich zien te onttrekken aan de inwerking van de brontaal op de doeltaal (interferentie). Is hij daartoe niet in staat, dan zal zijn taalgebruik morfologisch, syntactisch, lexicaal of stilistisch sporen van de vreemde taal vertonen en buiten de conventies en regels van de doeltaal vallen. Het gevolg daarvan is dat de aandacht van de lezer, buiten de bedoeling van de schrijver om, gevestigd wordt op de talige kant van de tekst. Hoewel zelfs de meest ervaren vertaler hiervoor op zijn hoede moet blijven, is een vroege vertaaltechnische vorming, bij voorkeur voor de specifieke talen en vertaalrichting waarin de vertaler zich specialiseert, de manier bij uitstek om aan interferentie te leren ontkomen en verkeerde gewoontes te vermijden. Helaas zijn vertaalkundige werken op dat gebied niet voor alle talenparen voorhanden en moet men in sommige gevallen zijn toevlucht nemen tot vertaalvademecums voor verwante talen of zich laten onderrichten door ervaren vertalers of vertaaldocenten. Vaak ook wordt het interferentieprobleem behandeld binnen een ruimer kader van talenpaargebonden vertaaltechnieken. Vertaalkundige werken en comparatieve studies voor specifieke talenparen zijn terug te vinden in de Kennisbank.

\section{Stilistisch vermogen en creativiteit}

Wat op het $\mathrm{C}_{2}$-niveau gold voor de autonome vorm van creatief schrijven, geldt niet minder voor de bemiddelende activiteit: de literair vertaler moet in de doeltaal geoefend zijn in verschillende stijlen, afgestemd op het genre van de tekst. Bovendien moet hij, bij specifieke uitdagingen, een literair-technische creativiteit aan de dag weten te leggen. Volleerde vertalers hebben deze vaardigheden niet zelden verworven door oefeningen in het imiteren, pasticheren, parodiëren, om verschillende stijlen in de vingers te krijgen en zichzelf te dwingen tot creatieve oplossingen. Stijloefeningen (1978), Rudy Kousbroeks vertaling van de Excercises de style (1947) van Raymond Queneau, is sinds lang het schoolvoorbeeld van stilistische vingeroefeningen. Battus' rijke Opperlans! $\left(2 \mathrm{OO}^{2}\right)$ blijft, als illustratie van bijzondere taalverschijnselen en -procedés, een van de meest stimulerende werken om de creatieve motor te laten aanslaan - onafhankelijk van de vertaalrichting. 


\section{Het gebruik van digitale tools}

De mate waarin de vertaaltechnologie (vertaalgeheugen, terminologiebeheer, vertaalmachine, vertaalbeheersystemen, kwaliteitscontroleprogramma's) de literair vertaler bij het vervaardigen van zijn literaire tekst van nut kan zijn, lijkt vandaag nog beperkt. Bovendien zijn die instrumenten vaak tijdrovend (bijv. zelf op te bouwen), duur (in aankoop en technische vereisten) en is wat ze aanleveren, niet zomaar inpasbaar (en vraagt het nog heel wat nabewerking) (Michiels 2018). Zulke tools - alsook online computervertaaldiensten - mogen dan bruikbaar zijn voor aspecten die bepaalde literaire teksten met technische, zakelijke, juridische ... teksten delen, een belangrijk bezwaar blijft toch dat eerstgenoemde teksten zich van die andere teksttypen op een aantal punten onderscheiden, zoals hun doel, hun literaire karakter, hun relatie tot de taal en de werkelijkheid, bepalend voor het leesproces en voor de criteria bij het vertalen.

Wat een literair vertaler vandaag vermoedelijk het meest van nut is, zijn digitale corpora (bijv. van de te vertalen of een verwante auteur; of van generisch, thematisch of stilistisch verwante teksten in bron- of doeltaal) om die syntactisch, lexicaal, stilistisch te peilen of op zoek te gaan naar intertekstualiteit, terugkerende motieven of andere verbanden. Men kan daarbij gebruikmaken van bestaande corpora (in de mate waarin die voorhanden zijn) of ze zelf naar behoefte samenstellen. Het samenstellen van parallelcorpora, waarbij vertalingen naast bronteksten worden geplaatst, is vanaf een zekere omvang nogal bewerkelijk, maar kan in het kader van grotere vertaalopdrachten of -projecten (zoals hervertalingen van hoogwaardige literaire teksten, 'oeuvrevertalingen') zeker de moeite lonen.

\section{De vertaler als eerste lezer en redacteur}

In het laatste stadium - misschien ook eerder al, op gezette tijden - verplaatst de vertaler zich in de toekomstige lezer en in de redacteur, beiden lezers die de vertaling meestal als autonome tekst zullen lezen. De vertaler wordt lezer van zijn eigen tekst, voor onervaren vertalers soms een lastige oefening. ${ }^{5}$ Ten behoeve van de doeltaallezer wordt per tekstdeel een laatste maal ingeschat of de leeservaring in de doeltaal wel de gewenste of nagestreefde zal zijn, of de tekst stilistisch deugt, of zinsverbindingen

$5 \quad$ Zie ook 4.1. 
en zinsbouw het goede verloop van de tekst garanderen, of de aandacht van de lezer niet van de tekst afgeleid zal worden op de plekken waar de vertaler hobbels te nemen kreeg et cetera. Voor de redacteur wordt scrupuleus gecheckt of de tekst vrij is van taaltechnische of literair-technische fouten of gebreken en wordt gestreefd naar een schone kopij, waarvan typografie en opmaak beantwoorden aan de huisregels en/ of aan de algemene regels en conventies in het taalgebied. Het is nuttig om daarbij gebruik te maken van een deels persoonlijk opgebouwde (eerdere onhandigheden of uitglijders), deels algemene checklist met aandachtspunten, te controleren aspecten, specifieke fouten, geregeld te vinden in professionele of vertaalkundige literatuur. Ook stijlboeken en redactiewijzers in de doeltaal, eveneens terug te vinden in de Kennisbank, zijn in dit verband doeltreffend. Ten slotte dient nog opgemerkt dat het nalezen van vertalingen van vakgenoten of het vergelijken van bestaande vertalingen niet alleen de vertaalvaardigheid, maar ook het zelfrevisievermogen vergroot.

\section{Bibliografie}

Battus. Opperlans!: taal- \& letterkunde. Amsterdam: Querido, $2002^{2}$.

Michiels, Shana. "Lost in translation technology: vertaaltechnologie, een overzicht." Ad rem 2 (2018), p. 11-14.

Nederlandse Taalunie. Gemeenschappelijk Europees referentiekader voor moderne vreemde talen: leren, onderwijzen, beoordelen (ERK). Den Haag: Nederlandse Taalunie, 2008. Te raadplegen via: http://taalunieversum.org/publicaties/gemeenschappelijk-europees-referentiekader-voor-moderne-vreemde-talen-leren-onderwijzen. Geraadpleegd 12 maart 2019.

Nord, Christiane. "Tekstanalyse en de moeilijkheidsgraad van een vertaling." In Ton Naaijkens, Cees Koster, Henri Bloemen \& Caroline Meijer (red.), Denken over vertalen: tekstboek vertaalwetenschap. Nijmegen: Vantilt, $2010^{2}$, p. 145-152.

Petra-E Network. Petra-E Europees referentiekader voor de opleiding \& deskundigheidsbevordering van literaire vertalers, 2016-2017. Te raadplegen via: https://petra-educationframework.eu/nl/. Geraadpleegd 12 maart 2019.

Queneau, Raymond. Stijloefeningen. Vertaald door R. Kousbroek. Amsterdam: De Bezige Bij, 1978 (oorspronkelijk werk gepubliceerd in 1947).

Sanders, Ewoud. Slimmer zoeken op internet. Amsterdam: Xander Uitgevers, 2015.

Willaert, Tom, Dirk Speelman en Fred Truyen. Digitale geletterdheid: dataverwerking in de geesteswetenschappen. Leuven: Universitaire Pers, 2018. 



\title{
1.3. \\ Naslag
}

\section{Chris Van de Poel}

\begin{abstract}
Alvorens ons aan vèr voerende interpretaties te wagen, moeten we misschien eerst nederig kijken naar wat er staat. Dat kan paradoxaal genoeg alleen door de woorden van de tekst te betrekken op en te vergelijken met woorden uit andere teksten: woordenboeken, lexica, idiotica, encyclopedieën, grammatica's, parallelteksten, grondteksten. (P. Claes, Gezelle gelezen, 1993)
\end{abstract}

De in het motto beschreven werkwijze werd reeds door de Alexandrijnse filologen ontwikkeld, wordt ook vandaag nog door Paul Claes bepleit. Naslag is cruciaal, in dit geval voor het begrip van de brontekst: de tekst verbindt zich generisch, tekstueel, lexicaal met de taal en haar literaire, culturele en maatschappelijke traditie en omgeving; de tekst bevat per definitie echo's en de beginnende noch de ervaren vertaler kan ervan uitgaan dat zijn kennis van brontaal, -cultuur en teksttraditie toereikend is.

Maar de vertaler maakt, zoals hierna wordt geschetst, nog een ruimer gebruik van naslagwerken. In het algemeen zoekt een vertaler ontzettend veel op. Dat is in meer stadia bevorderlijk voor de kwaliteit en de snelheid van zijn werk. Als vakman dient hij zijn instrumentarium te kennen en heeft hij het binnen handbereik. Ongeacht het medium (gedrukt of digitaal) neemt hij vooraf de toelichtingen van de makers en de gebruiksaanwijzing door, om het volle nut uit het werk te kunnen halen. Ook eigen ondervinding of die van vakgenoten, formeel of informeel gedeeld (via publicaties, professionele platformen, sociale contacten, al dan niet online), dragen bij tot de voortdurende uitbreiding van zijn kennis en vaardigheid op dit punt. In dit hoofdstuk over het gebruik van naslagwerken wordt opnieuw gemakshalve de lineaire voorstelling van het vertaalproces gehanteerd, van de eerste lectuur van de brontekst tot het afronden van de vertaling. Ook ditmaal geldt dat die voorstelling 
enigszins kunstmatig is, aangezien de vertaler die steeds verder probeert door te dringen in de tekst, evengoed circulair te werk gaat (in verschillende lees-, vertaal-, redactierondes) of uiteenlopende hulpmiddelen gelijktijdig inzet.

De Kennisbank van het ELV, voor vertalers in en uit het Nederlands, bevat een rubriek die een kijk biedt op veelgebruikte naslagwerken. In wat volgt, zal gefocust worden op soorten naslagwerken, terwijl concrete titels per taal te vinden zijn in de Kennisbank.

\section{Het verklarende woordenboek als sleutel ...}

Bij het lezen van de brontekst moet de vertaler geregeld op zoek naar de betekenis of het specifieke gebruik van woorden en uitdrukkingen. ${ }^{1}$ Daarbij grijpt hij in de eerste plaats naar (de meest volledige uitgave van) het eentalige of verklarende woordenboek: dat bevat in principe (indien geregeld bijgewerkt) het ruimste aanbod aan woorden en uitdrukkingen en de meest uitgebreide betekenisbeschrijvingen. Wie daarentegen de brontekst wil doorgronden op basis van het vertalende woordenboek, met minder betekenissen per lemma en trager in de opname van recente woorden en betekenissen, begaat gemakkelijker interpretatiefouten. Hetzelfde bezwaar treft overigens de 'encyclopedische woordenboeken', die zich aandienen als encyclopedie én als woordenboek maar met hun dubbele focus al te vaak op beide vlakken tekortschieten.

Het verklarende woordenboek helpt de vertaler niet alleen de betekenis bloot te leggen, maar kan ook de overgang naar de doeltaal - de transfer - als het ware op gang brengen: bij het lezen van de betekenisomschrijvingen en het voorbeeldmateriaal komt de vertaler alvast los van de specifieke verwoording in de brontaal, waardoor een al te letterlijke vertaling kan worden vermeden. Ook kan (literair) voorbeeldmateriaal uit het (groot) verklarend woordenboek de vertaler weleens op het spoor zetten van intra- of intertekstuele verbanden. Het kan de beginnende vertaler aanvankelijk zwaar vallen om met voldoende regelmaat het woordenboek in de brontaal te raadplegen, maar het is een vaardigheid die zich snel laat opbouwen en die van meet af aan loont.

1 Zie ook 1.4. 


\section{Welk verklarend woordenboek te kiezen?}

Het ene woordenboek is het andere niet. Bij de keuze voor een specifiek woordenboek laat de vertaler zich leiden door de volledigheid ervan en het gezag dat het (de makers, het lexicografische instituut) binnen het vak (volgens vakbladen, vakliteratuur, ervaringskennis) in zijn geheel of op bepaalde punten geniet. Hoe dan ook beperkt de ervaren vertaler zich zelden tot één verklarend woordenboek, maar combineert hij waar mogelijk de verschillende standaardwerken in de brontaal. Factoren die zijn keuze verder kunnen bepalen zijn de ontstaansperiode en aard van de brontekst enerzijds en specifieke troeven van het naslagwerk anderzijds: de specificiteit en nuanceringsgraad van de betekenisomschrijvingen; de aandacht voor connotaties, fraseologie en gebruik van taaluitingen in context, register en stilistische variatie, taalvariatie (geografisch, sociaal, professioneel), de kwaliteit van het voorbeeldmateriaal (authentiek versus maakwerk) et cetera.

In de reeds genoemde rubriek van de ELV-Kennisbank attendeert een korte annotatie op relevante kenmerken van de opgenomen werken of wordt kritisch advies gegeven.

\section{3. ... een onmisbare dienaar, maar geen meester}

Telkens als het begrip van de tekst tijdens het lees- en vertaalproces voor de vertaler twijfelachtig wordt, maar evengoed op momenten dat hij de betekenis wel denkt te zien, is het gebruik van het verklarende woordenboek zinvol. De kunst is de eigen brontaalkennis juist in te schatten en aan te voelen wanneer begripsfouten of andere blinde vlekken dreigen. Uit de aard van zijn bezigheid is de vertaler zich meer dan wie ook bewust van het opduiken van nieuwe woorden, onbekende betekenissen of zeldzame betekenisaspecten in tekst en taal, niet het minst in de 'creatieve' tekstsoort waartoe literaire tekstsoorten behoren.

Bij een nog prille brontaalkennis is het openslaan van het verklarende woordenboek vrijwel de enige manier om te ontkomen aan misleiding door 'valse vrienden' (vooral de meer subtiele gevallen dan die uit de vaste lijstjes). Ook een geringe idiomatische kennis moet aanzetten tot woordenboekgebruik, al kan het verklarende woordenboek, niet specifiek bedoeld voor de vreemdetaalgebruiker, op dat punt nooit

2 Zie ook 2.3. 
voldoende ondersteuning bieden. Het taalbad en het contact met native speakers (of geoefende 'native readers') blijven dus onmisbaar. In het geval van individueel bepaalde taaleigenaardigheden ('idiosyncrasieën') kan de vertaler zich dan weer gedwongen zien om contact op te nemen met de auteur ${ }^{3}$ of kritische studies te raadplegen.

Toch is het belangrijk het woordenboek, dat ook het resultaat van mensenwerk is en onnauwkeurigheden of fouten kan bevatten, altijd met een kritische blik te hanteren. Bovendien vereist het juiste begrip van de tekst dat de vertaler pendelt tussen de beschreven betekenissen (het werk van lexicografen) en de zins- en hogere tekstverbanden waarin het item in de te vertalen tekst verschijnt (het werk van de auteur). De vertaler verliest de omringende tekst en het geheel van de tekst nooit uit het oog. Die zijn vrijwel altijd indicatief of sturend voor de interpretatie, of deze nu semantisch, stilistisch, of pragmatisch is.

\section{Een efficiënt gebruik van het verklarende woordenboek}

Behalve het raadplegen van het naslagwerk op zich, is de manier waarop men dat doet belangrijk. Het komt erop aan zich vertrouwd te maken met de zoekmogelijkheden - die digitaal veelal uitgebreider zijn dan in gedrukte werken - en te weten welke (altijd meervoudige, grammaticale, lexicale en andere) informatie het werk en de artikelen bevatten (zoals woordgeslacht, meervoudsvorm, verkleinwoord, trappen van vergelijking, woordvormen, connotaties, register etc.). Ook bekendheid met het concept aan de basis of de organisatie van het werk op diverse niveaus kan bepalend zijn voor het gebruik.

Wie zich niet bewust is van de chronologische opbouw van de betekenisbeschrijvingen in het Groot woordenboek van de Nederlandse taal (tabblad 'Dikke Van Dale') over de periode vanaf 1880 , zal zich verkijken op het effect van zijn - mogelijk al in onbruik blijkende - woordkeuze. Evenmin is dan de verhouding in te schatten tussen de 'Dikke Van Dale' en Van Dale Hedendaags Nederlands (tabblad 'Nederlands'). Dat laatste woordenboek heeft een focus op de vandaag (nog) actieve betekenissen. In het licht van het voorgaande is te begrijpen waarom het artikel 'lezen' in het eerste woordenboek begint met de betekenis 'verzamelen', in het tweede woordenboek met 'kennisnemen van de inhoud van'. Of nog, wie niet weet dat hij het digitale

3 Zie ook 1.5. 
woordenboek kan laten doorzoeken op basis van de labels (bijv. 'vulgair' of 'formeel'), mist de kans om de volledige lijst van identiek gelabelde items te zien te krijgen ('binnen artikelen').

Ten slotte zijn een taalkundige vorming (terminologisch en inzichtelijk) en een voldoende zuiver en verfijnd taalgevoel (reeds ontwikkeld vanuit de moedertaal) vereisten voor een efficiënt en juist gebruik van het woordenboek: wie het verschil tussen de aanduidingen 'voegwoord' en 'bijwoord' niet begrijpt of wie geen aandacht heeft voor de door de lexicografen aangebrachte nuances (het verschil tussen 'kosten' en 'onkosten', 'inwoner' en 'bewoner', 'geheim' en 'mysterieus'), begaat vroeg of laat fouten.

\section{Meer naslagwerken}

Naast het verklarende woordenboek gebruikt de vertaler, ter ontsluiting van de brontekst of ter duiding van buiten- en intertekstuele elementen of codes in het semantische universum van de tekst, nog vele andere, al dan niet periodegebonden naslagwerken (daterend uit of gericht op een specifieke periode). Men kan daarbij denken aan algemene of gespecialiseerde encyclopedieën; woordenboeken met biografische informatie, pseudoniemen, heteroniemen, of initialen; adelboeken; historische en etymologische woordenboeken; vakwoordenboeken of lexica; beeldwoordenboeken; woordenboeken met specifiek etnolect, sociolect, groepstaal (het Afro-Amerikaans, het Italiaans-Nederlands, homo-erotische taal, zeemanstaal, argot, jeugdtaal etc.); idiotica of dialectwoordenboeken; naslagwerken voor afkortingen, letter(greep)woorden, sms-taal, neologismen, eufemismen, taboewoorden, scheldwoorden en schimpnamen; voor spreekwoorden, anagrammen, woordspelingen, populaire uitdrukkingen en clichés. Verder raadpleegt de vertaler uitgesproken letterkundige, culturele, historische naslagwerken: concordanties, motievenindexen; woordenboeken met symbolen, personages, citaten en gevleugelde woorden, liederen en rijmpjes et cetera. Het mag dan haast een rabelaisiaanse opsomming lijken, ze is wel kenschetsend voor de grondigheid waarmee men in het vak bij voorkeur te werk gaat.

Het aanbod is zeer rijk, maar de vertaler kiest, behalve de meest betrouwbaar geachte, ook graag de meest handzame werken: ze moeten meer zijn dan een lijst met taalweetjes of -curiosa en beschikken over een thematisch register of een systematische ordening die het professioneel zoeken (bijv. in beide richtingen: van algemeen 
naar specifiek, van hyperoniem naar hyponiem en vice versa) mogelijk maakt. Voor grasduinen is er in de werkkamer van de vertaler weinig tijd, voor investering in gebruiksonvriendelijke naslagwerken is zijn vaak beperkte budget niet bedoeld.

\section{Het vertaalwoordenboek}

Zodra de tekst als geheel en in delen voldoende begrepen is om over te gaan tot weergave in de doeltaal, kan de vertaler gebruikmaken van de tweetalige (of meertalige) woordenboeken en zich laten inspireren door de vertaalsuggesties die hij daarin aantreft. Aangezien hij in die fase niet meer afhankelijk is van het woordenboek om de tekst te begrijpen, valt het hem snel op als een voor de brontekst relevante betekenisweergave ontbreekt of als de gesuggereerde vertalingen niet geschikt zijn. Omgekeerd zal hij de meest toepasselijke vertaling binnen het rijtje vertaalsuggesties met gemak weten te 'herkennen', als die voorkomt. Geruststellend is dat, als het vertalende naslagwerk niet voldoet, het begrip van de brontekst niet meer in gevaar kan komen; de vertaler zal in dat geval een andere vertalende bron raadplegen, indien voorhanden.

Vertaalsuggesties in het vertalende woordenboek vormen niet meer dan een aanloop tot het schrijven van de doeltekst. Dit woordenboek maakt de vertaler immers zelden wijzer aangaande het gebruik van het woord of de uitdrukking in de doeltaal, connotatie, register, frequentie, contexten waarin het verschijnt, mogelijke associaties ... Daarvoor moet hij zijn toevlucht nemen tot de verklarende woordenboeken in de doeltaal. Ook zijn 'vertalingen' voor cultuurspecifieke elementen in vertalende woordenboeken geregeld niet meer dan parafrasen (in Van Dale S-N voor mesa camilla: 'rond tafeltje met vuurpothouder' of 'ronde tafel (gewoonlijk met een afhangend kleed)') en dient de vertaalslag nog gemaakt. Daarbij komt dat de doeltekst in wording op verschillende tekstuele niveaus (zinsdeel, zin, alinea, hoofdstuk, hele werk - d.i. van micro- tot macroniveau) en op verschillende punten keuzes zal vereisen die afgestemd zijn op en voortkomen uit het geheel van het werk. Het is daarom te begrijpen dat de vertaler, ook in het geval van het vertaalwoordenboek, altijd met een zeker voorbehoud en met een kritisch oog kijkt naar wat het woordenboek aanreikt. 


\section{Meer doeltaalspecifieke naslagwerken}

Bij het schrijven in de doeltaal richt de vertaler zijn volle aandacht op de kwaliteit van de tekst als zelfstandige tekst in de doelcultuur en voor de doeltaallezer. De doeltekst op zich is vaak het enige facet van de vertaalarbeid dat de lezer te zien krijgt en het eerste waarop de vertaler wordt beoordeeld. Van de vertaler, die in de regel in de moedertaal vertaalt, wordt een veelomvattende, grondige en verfijnde kennis van de doeltaal verwacht. Alle middelen die de professionele taalgebruiker, tekstschrijver en redacteur ondersteuning kunnen bieden, worden dan ook door hem benut: spelling- en leestekengids, grammatica, voorzetselwoordenboek, combinatiewoordenboek, thesaurus of synoniemenwoordenboek, stijlboek, titulatuurgids, spreekwoordenboek, retrograde en rijmwoordenboek, handboek revisie- en redactie et cetera. Ook van de eerder beschreven waaier van naslagwerken ter ontsluiting van de brontekst zal hij gebruikmaken, maar ditmaal in de doeltaal.

\section{Digitaal naslaan}

Veel naslagwerken zijn vandaag de dag online of digitaal op het spoor te komen en, gratis of tegen betaling, te raadplegen (waarmee overigens veel waardevols dat niet digitaal aangeboden wordt, aan de blik onttrokken dreigt te raken). In de reeds genoemde rubriek van de ELV-Kennisbank wordt ernaar, per taal, verwezen. Hieronder schetsen we summier enkele, door vertalers graag gehanteerde vormen van online naslag.

Dankzij zoekmachines, portaalsites, (van lokale tot internationale) online catalogi, bibliografieën, databanken, verzamelpagina’s, (ver)taalsites zijn naslagwerken (relatief) gemakkelijk te lokaliseren en volstaan soms enkele kliks om ze te kunnen raadplegen. Om autonoom op een efficiënte wijze naslagwerken te lokaliseren is al wat meer digitale vaardigheid nodig. Digitale bibliotheken en databanken bieden eigen geavanceerde zoekmogelijkheden, maar laten zich geregeld ook rechtstreeks vanuit het zoekvenster van de zoekmotor (bijv. Google, Bing, Yahoo) doorzoeken.

Het aantal verklarende en twee- of meertalige online woordenboeken is groot. Voor het Nederlands zijn de lexicografische en terminologische activiteiten en het online aanbod van het Instituut voor de Nederlandse Taal cruciaal. Voorts nemen de verklarende en meertalige woordenboeken met spiltaal Nederlands van Van Dale Uitgevers een prominente plaats in. Ook het online encyclopedische 
aanbod is groot, waarvan Wikipedia - zelf vandaag de alomtegenwoordige online encyclopedie - voor verscheidene talen een (niet noodzakelijk volledig) overzicht biedt ('internetencyclopedieën').

Niet alle online naslagwerken laten zich even gemakkelijk raadplegen of bieden uitgebreide zoekmogelijkheden. Toch kan een vertaler ook geregeld zijn voordeel doen met het minder gebruiksvriendelijke aanbod van oudere gedrukte naslagwerken in (niet altijd doorzoekbare) pdf's, vaak aangeboden via de digitale bibliotheek van de grote (nationale of wetenschappelijke) bibliotheken of als particulier al dan niet tegen betaling aan te vragen.

Wetenschappelijke of academische onderzoeksresultaten en publicaties zijn in toenemende mate toegankelijk dankzij open access. Met de zoekmachine Google Scholar zijn tal van wetenschappelijke artikelen en documenten doorzoekbaar, waarvan vele eveneens integraal toegankelijk zijn. Op die manier hebben vertalers letterkundige, literair- en vertaalwetenschappelijke bevindingen en inzichten binnen handbereik.

Zoals reeds aangegeven in het vorige hoofdstuk gaan vertalers ook graag zelf met digitale tekstcorpora aan de slag om teksten in bron- of doeltaal syntactisch, lexicaal, stilistisch te peilen of te verkennen. Ze maken gebruik van bestaande (eentalige of meertalige) corpora of stellen ze zelf naar behoefte samen. Project Gutenberg, Wikisource, Google Books zijn enkele van de vrij beschikbare tekstverzamelingen, maar ook wetenschappelijke instellingen stellen in toenemende mate corpora ter beschikking via hun digitale bibliotheek. In de omvangrijke verzameling van Google Books kan, al dan niet in een meer specifiek corpus, met de Ngram Viewer nagegaan worden hoe vaak een woord of zinsnede in een af te bakenen periode voorkomt. Diezelfde functie wordt thans ook door de DBNL aangeboden om de door haar gedigitaliseerde teksten op woorden of frases, met of zonder genrespecificering, te doorzoeken.

Het aantal online naslagwerken mag dan groot zijn en online hulpmiddelen mogen al geregeld geüpdatet worden, toch mag de kritische aandacht voor de wetenschappelijke, letter- of taalkundige kwaliteit, de volledigheid en precisie van het aangebodene niet verslappen. Termenbanken, etymologiebanken, liederenbanken et cetera zijn een luxe voor de literair vertaler indien ze meer zijn dan een oneindige verzameling van items en op voorwaarde dat ze als kennisbron de toets der kritiek kunnen doorstaan. In dat verband is het belangrijk na te gaan wie verantwoordelijk is voor de website of de aangeboden bron en welk gezag er door deskundigen aan wordt toegekend. 


\section{Het web als één grote documentatiebron en een veelzijdig communicatiekanaal}

De komst van het web heeft niet alleen met betrekking tot kennisbronnen en relevant tekstmateriaal de omstandigheden voor de literair vertaler - en dus zijn werkomgeving - sterk veranderd. Ook vormt het web het middel bij uitstek om snel te reizen en zich - met een beperkte investering van geld en tijd - te begeven naar het land, het taalgebied, de cultuur van oorsprong en zich te bewegen in met klank en beeld ondersteunde (zij het virtuele) omgevingen. Stadswijken, musea, tentoonstellingen, monumenten, bibliotheken, begraafplaatsen enzovoort laten zich steeds vaker online bezoeken. De diensten van Google (Google Maps, Google Images, Google Arts \& Culture) zijn daarbij voor menig vertaler onmisbaar geworden, maar ook andere zoekmachines (Bing, Yahoo) hebben een verwant aanbod. Google Videos en YouTube (al dan niet YouTube Edu, voor educatieve video's) zijn voor vertalers dan weer geregeld van nut om beschrijvingen van of allusies op onbekende situaties, praktijken, handelingen, bewegingen et cetera te verhelderen: door de beschreven werkelijkheid achter de bewoordingen te zien, komt men tot een juister begrip van de brontekst en tot een rakere verwoording in de vertaling. Waar neemt de verdediging precies plaats tijdens een Braziliaanse strafzitting? Hoe wordt kurk geoogst? Op welk klein element uit de lokale klederdracht wordt in de brontekst gezinspeeld? Met welke lichaamshouding of welke bewegingen gaat het bespelen van bepaalde muziekinstrumenten gepaard?

Ten slotte staat het web de vertaler vandaag de dag ook ter beschikking als onvervangbaar hulpmiddel voor netwerken, communicatie, het delen van expertise, documenten en inhouden, via e-mail, blogs, fora et cetera.

\section{Bibliografie}

Brosens, Koenraad, De Wachter, Lieve, \& D'Hertefelt, Margot. Van blokdruk tot blog: omgaan met informatie en tekstgenres in de geesteswetenschappen. Leuven: Universitaire Pers Leuven, 2018.

Claes, Paul. Gezelle gelezen. Leiden: Dimensie, 1993.

Sanders, Ewoud. Slimmer zoeken op internet. Amsterdam: Xander Uitgevers, 2015.

Willaert, Tom, Speelman, Dirk, \& Truyen, Fred. Digitale geletterdheid: dataverwerking in de geesteswetenschappen. Leuven: Universitaire Pers Leuven, 2018. 



\title{
1.4. \\ Hoe bronteksten lezen?
}

\author{
Philippe Noble
}

Heel ruw gezegd zou je de vertalende activiteit als volgt kunnen omschrijven: iemand leest zo zorgvuldig mogelijk een tekst in een bepaalde taal en brengt naderhand schriftelijk verslag uit van zijn lectuur, maar dan wel in een andere taal. Dat heeft me weleens ertoe gebracht om te beweren dat een vertaling - qua soort tekst, niet qua inhoud - verwant is aan een commentaar. Of, om het in de woorden van Ton Naaijkens te zeggen: vertalen is "een drievoudige combinatie van goed lezen, goed schrijven, en goed lezen goed omzetten in goed schrijven" (Naaijkens 2002: 34).

Alles begint dus bij lezen, en van vertalers wordt verwacht dat ze 'ideale lezers' zijn. Maar wat houdt dat in? Welke voor vertalers relevante vaardigheden zijn daarbij vereist? Een algemeen antwoord op deze vraag is te vinden in het Europees Referentiekader voor de opleiding en deskundigheidsbevordering van literair vertalers dat in 2016 op initiatief van het Petra-E Network tot stand is gekomen (Petra-E Network 2016-2017). Van de acht in het document genoemde competenties die vertalers zouden moeten bezitten, zijn er vier die op verschillende manieren verband houden met lezen:

- Talige competentie (2): (...) grammaticale, stilistische en pragmatische beheersing van de brontaal en de doeltaal in het bijzonder op het gebied van lezen en schrijven.

- Tekstuele competentie (3): De kennis van literaire genres en stijlen en het vermogen om die kennis toe te passen bij de analyse van bronteksten en de productie van doelteksten.

- Heuristische competentie (4): Het vermogen om op efficiënte manier de talige en thematische kennis te verzamelen die nodig is om een brontekst te begrijpen en een doeltekst te produceren (...).

- Literair-culturele competentie (5): Het vermogen om kennis van de bron- en doelcultuur in te zetten bij het maken van literaire vertalingen. 
Achter die abstracte formuleringen schuilen zeer concrete problemen, die ik nu zal trachten te illustreren aan de hand van een paar voorbeelden. Ik beperk me daarbij tot het talenpaar Frans/Nederlands, de voornaamste werktalen in mijn vertaalpraktijk. Daarbij komt een auteur als Marcel Proust veelvuldig aan bod omdat ik me nu eenmaal recentelijk met hem heb beziggehouden.

\section{Polysemie}

Beheersing van de brontaal (competentie 2) lijkt als vereiste zo vanzelfsprekend dat die nauwelijks commentaar behoeft. Toch wil ik eerst stilstaan bij verborgen moeilijkheden die zich al op woordniveau bij betekenistoekenning voordoen. $\mathrm{Ze}$ houden in het bijzonder verband met de bekende polysemie van Franse woorden. Ik begin met twee zelfstandige naamwoorden die iedere Nederlandstalige denkt te kennen, ook als hij of zij geen Frans geleerd heeft: cabaret en supplément. Los van de associatie met kleinkunst die het woord 'cabaret' in het Nederlands oproept verwijst het woord in het Frans meestal naar een café. Maar wat te denken van deze context: in À l'ombre des jeunes filles en fleurs van Marcel Proust dineert de oude diplomaat Norpois bij de ouders van de verteller. Om de gastvrouw te complimenteren over de kwaliteit van de gerechten zegt hij: "Zoiets kun je niet krijgen in een cabaret." Een vreemd compliment: uiteraard worden in een kroeg zulke verfijnde gerechten niet geserveerd. Maar rond 1900 kon het woord nog slaan op een deftig restaurant, al hoorde het toen al onmiskenbaar bij oubollig taalgebruik, waarop het personage Norpois in de roman patent heeft. Nog duidelijker is het voorbeeld van supplément, Vandaag de dag betekent het 'toevoegsel, toeslag'. Maar tweehonderd jaar geleden droeg het woord nog sporen van zijn Latijnse oorsprong en betekende het naast 'aanvulling' ook 'vervanging', 'surrogaat'. Juist in die laatste betekenis komt het nog veel voor bij auteurs als Rousseau, Chateaubriand of Lamartine.

Beide voorbeelden hebben betrekking op de geschiedenis van de Franse taal, de semantische ontwikkeling van woorden. Houdt dat in dat een (beginnende) vertaler naast gangbare, ook oude, verdwenen betekenissen van woorden per se moet kennen (zie competenties 2 en 3)? Nee, maar hij moet in staat zijn om in digitale of papieren naslagwerken de juiste betekenis op te sporen (heuristische competentie, 4). En dat laatste veronderstelt - dat is hier mijn punt - een bijzondere lezershouding. Je moet als (vertalende) lezer alert zijn op alle signalen die een tekst uitzendt: bijvoorbeeld als een vertrouwde, voorspelbare betekenis van een woord of uitdrukking vreemd 
aandoet in een bepaalde context. En dan moet je ook bereid zijn om de oorzaak van die vreemdheid tot op de bodem uit te spitten. En ook accepteren dat je af en toe moeilijk voor één betekenis kunt kiezen. Het doodgewone Franse voorzetsel de is op zich al een berucht geval van polysemie. Het betekent 'van', maar naargelang de context ook 'aan', 'in', 'op', 'uit' enzovoort. En soms correspondeert het met twee voorzetsels tegelijk: de polyglotte Franz Liszt gaf aan een van zijn composities de Franse titel Pensées des morts mee. En daarmee kunnen niet alleen de 'gedachten van', maar ook de 'gedachten aan' de doden worden bedoeld. Zulke dubbelzinnigheden bestaan ook in het Nederlands, vooral bij poëzie, zoals in de beroemde versregels uit 'O Engeitado' van Slauerhoff (1947: 202):

Nu weet ik waaraan ik zal sterven:

aan de oevers van den Taag.

\section{De lezer werkt mee aan het verhaal}

In werkelijkheid lezen we niet op het niveau van afzonderlijke woorden, maar van hele zinnen of zelfs van alinea's en al lezende construeren we hypotheses over de betekenis ervan. Dat is in het bijzonder het geval bij verhalend proza, zoals literatuurwetenschappers en semiotici als Tzvetan Todorov of Umberto Eco, Gérard Genette of Roland Barthes al in de jaren 70 van de vorige eeuw hebben laten zien. De manier waarop we een verhaal lezen is altijd een mentale, dus subjectieve (re)constructie, ook al is die verankerd in tekstelementen die een objectieve werkelijkheid vormen. De tekst zendt signalen uit, roept bij de lezer verwachtingen op, laat hem elementen invullen die niet met zoveel woorden vermeld staan enzovoort. Met andere woorden: lezen en interpreteren zijn onafscheidelijk met elkaar verbonden. Dat verklaart dat er - vergissingen daargelaten - vrijwel altijd meerdere vertalingen mogelijk zijn van één zin in een literaire tekst.

Bovengenoemde theoretici hebben ons in het bijzonder vertrouwd gemaakt met het begrip vertelperspectief. In de klassieke vormen van de roman is er een auctoriële stem, een alwetende verteller, die zich rechtstreeks tot de lezer richt, of een personage die in de eerste persoon zijn (of haar) eigen verhaal vertelt. In de loop van de vorige eeuw zijn complexere vormen opgekomen, waarbij een verhaal vanuit het standpunt van wisselende personages verteld kan worden, zonder dat deze figuren expliciet aan het woord zijn. Het is vandaag de dag misschien zelfs de meest voorkomende 
vorm van vertelling. In romans van Arnon Grunberg - ik denk bijvoorbeeld aan Tirza (2008) of Huid en haar (2010) - staat er vrijwel niets dat niet door de ogen van de protagonisten wordt gezien, terwijl de vertelling bedrieglijk neutraal en objectief oogt. Van een indringende lezer mag worden verwacht dat hij oog heeft voor dergelijke nuances, die soms ook voor vertaalproblemen kunnen zorgen. Aan de lijst vaardigheden die in het Europees Referentiekader worden genoemd zou ik daarom graag de narratologische vaardigheid expliciet toegevoegd zien.

Onder deze noemer valt mijns inziens ook aandacht voor syntactische aspecten van een tekst. Als we een roman of verhaal in hedendaags Nederlands lezen - bijvoorbeeld Bonita Avenue van Peter Buwalda (2010) - worden we doorgaans geconfronteerd met een overvloed aan werkwoorden in de o.v.t. die niet per se naar een homogene reeks handelingen verwijzen. Er kunnen daarbij flashbacks zijn, maar onder het lezen reconstrueren we spontaan de juiste chronologische volgorde. Ook begrijpen we spontaan of een handeling zich herhaalt, onbepaalde tijd voortduurt, of eenmalig is. Als we een dergelijke tekst in het Frans moeten vertalen, dat wil zeggen in een taal met een uitgebreider, gecompliceerder stelsel van (verleden) tijden, dan worden we opeens gedwongen onze spontane aannames zichtbaar te maken door te kiezen tussen tijden als imparfait, passé simple, passé composé of plus-que-parfait (zie bijvoorbeeld Buwalda 2013). Dezelfde noodzaak om te kiezen dringt zich ook op bij het vertalen van een werkwoordvorm als hij had kunnen komen, waarbij meestal wél - maar lang niet altijd - uit de context blijkt of we te maken hebben met een eerdere handeling in het verleden of een irrealis. Maar in alle gevallen moeten we er ons bewust van zijn dat onze vertaling geen intrinsieke eigenschap van een handeling reflecteert, maar in de eerste plaats onze interpretatie daarvan, en dat er misschien een andere visie op de tekst mogelijk is. Dat is de essentie van het lezen.

Belangrijk voor de coherentie van een tekst is het gebruik van voornaamwoorden. In het Frans kennen persoonlijke voornaamwoorden (en de bijbehorende bezittelijke voornaamwoorden) een veel bredere toepassing dan in het Nederlands. Vormen als il/elle/le/la/lui kunnen net zo goed naar stoffelijke of onstoffelijke zaken verwijzen als naar personen of levende wezens. Door een oud stilistisch taboe op het herhalen van een zelfstandig naamwoord binnen een zin of een korte alinea, een taboe dat zeker tot in hedendaags proza doorwerkt, is dit gebruik in het Frans enorm uitgedijd en bij complexe zinnen is het soms ook voor Franstalige lezers even puzzelen om het juiste antecedent te vinden. Verder spelen in Franse of Engelse zinnen voltooide en (nog meer) onvoltooide deelwoorden een veel grotere rol dan in modern Nederlands; daarmee kunnen zeer uiteenlopende verbanden uitgedrukt worden zoals oorzaak, 
tegenwerping, voorwaarde en dergelijke. Het gaat hier om banale syntactische feiten, maar ze dwingen de lezer wel degelijk tot het maken van hypotheses, die pas expliciet worden als hij zulke zinnen moet gaan vertalen.

\section{Een (halve) zin van Proust}

Terug naar Proust en naar zijn roman À l'ombre des jeunes filles en fleurs. Aan het voorbeeld van een - voor het doen van deze auteur - toch betrekkelijk korte zin zullen we zien dat bij het lezen, of beter gezegd het ontcijferen van een dergelijk tekstfragment alle hierboven beschreven competenties tegelijk en door elkaar ingezet moeten worden.

In deze passage is de ik-persoon, de jonge Marcel, ongeveer vijftien jaar oud; hij heeft een paar weken eerder een optreden meegemaakt van de beroemde actrice La Berma (die gemodelleerd is naar Sarah Bernhardt) en tijdens een slapeloze nacht denkt hij terug aan haar, waarbij hij zich voorstelt dat zij op hetzelfde moment de liefde bedrijft met een van haar minnaars, die naar hij veronderstelt talrijk zullen zijn. Deze typische seksuele fantasie (hoewel Proust de term niet gebruikt) roept bij de jongeman de volgende gevoelens op:

(...) j'éprouvais un émoi plus cruel qu'il n'était voluptueux, une nostalgie que vint aggraver le son du cor, comme on l'entend la nuit de la Mi-Carême, et souvent des autres fêtes, et qui, parce qu'il est alors sans poésie, est plus triste, sortant d'un mastroquet, que "le soir au fond des bois". (Proust 1954: 488-489)

Op het eerste gezicht is het zinsdeel niet moeilijk te begrijpen: de ik-persoon voelde 'een opwinding die eerder bitter dan wellustig was, een weemoed die opeens werd aangewakkerd door...' - ja, waardoor eigenlijk? Door de klank van een jachthoorn (le son $d u$ cor). Dat is vreemd, want zo'n klank verwacht je, zoals het einde van de zin trouwens aangeeft, 'diep in het bos' en niet in het hartje van Parijs, waar deze scène zich afspeelt. Waarom is er dan sprake van een bos? Omdat Proust een regel citeert uit een in Frankrijk beroemd gedicht van Alfred de Vigny ('De hoorn'): "God, wat klinkt de jachthoorn triest zo diep in het bos!" Uiteraard moet de lezer hier zijn intertekstuele competentie inzetten. ${ }^{1}$ Maar dit citaat dient enkel als

1 Voor het vertalen als intertekstuele praktijk, zie hoofdstuk 2.7. 
referentiepunt voor een door de schrijver niet helemaal geëxpliciteerde metafoor: hier komt de hoornklank dus niet uit een bos, maar uit een mastroquet, een ouderwets spreektaalwoord voor 'kroeg' (diachronische taalcompetentie). Nu hoort men dat hoorngeschal in kroegen niet altijd, lezen we verder, maar op 'Halfvastenavond' - in Frankrijk was dat een datum waarop men vroeger carnaval vierde - 'en op andere feestdagen', zoals in deze passage, want de scène speelt op 1 januari. (Om dit allemaal juist te taxeren moet de lezer al over een vrij diepgaande kennis van de Franse cultuur beschikken.) In het voorbijgaan heeft de lezer ook het onvoltooid deelwoord sortant als causaal verband geïnterpreteerd (syntactische competentie). Maar nog begrijpt men de zin niet helemaal: hoezo speelt men hoorn in kroegen? Hierin ligt juist de metafoor, die Proust ons laat raden. Het gaat dan ook niet om een echte hoorn, maar om een feestartikel, een 'carnavalsfluit' en de vergelijking is eerder malicieus of grappig bedoeld. Om de zin correct te duiden moest de lezer dus voldoende taalkennis bezitten en goed onderlegd zijn in de literatuurgeschiedenis, maar ook en vooral culturele elementen juist kunnen interpreteren. Het is dan aan de vertaler om te beslissen of hij in zijn weergave van de zin de vergelijking wil verduidelijken of niet. Een enigszins expliciterende vertaling van het einde van deze zin zou als volgt kunnen luiden:

(...) en hoornklank zoals je die op Halfvastenavond of op andere feestdagen hoort en die, aangezien hij dan geen poëtische bijklank heeft, droeviger is omdat het geluid door een carnavalsfluitje wordt voortgebracht en uit een kroeg opstijgt, en niet "s avonds diep in het bos'. (Proust 2018: 99)

\section{Besluit}

Er is geen onfeilbare methode voor het lezen van een te vertalen tekst. Alleen één ding is zeker: goed lezen berust op een grote hoeveelheid al vergaarde kennis en op de capaciteit die onder het leesproces met scherpe aandacht te mobiliseren. Of, zoals Ton Naaijkens het formuleert: "Het is een edel doel als de vertaler probeert de ideale lezer te zijn, maar het is geen sinecure alles uit een tekst te halen wat erin te lezen valt, alle mogelijke verwijzingen op te sporen en vervolgens weer te geven (...)" (Naaijkens 2002: 51). Het resultaat zou dan een total translation mogen heten. "Tot op heden", voegt hij eraan toe, "is het bestaan daarvan echter niet bewezen" (ibid.). 


\section{Bibliografie}

Buwalda, Peter. Bonita Avenue. Vertaald door Arlette Ounanian. Arles: Actes Sud, 2013.

Naaijkens, Ton. De slag om Shelley. Nijmegen: Vantilt, 2002.

Petra-E Network. (2016-2017). Petra-E Europees referentiekader voor de opleiding \& deskundigheidsbevordering van literaire vertalers. Te raadplegen via: https://petra-educationframework. $\mathrm{eu} / \mathrm{nl} /$

Proust, Marcel. À l'ombre des jeunes filles en fleurs. Édition de Pierre Clarac. Paris: Gallimard, Bibliothèque de la Pléiade, 1954.

Proust, Marcel. In de schaduw van meisjes in bloei. Vertaald door Philippe Noble en Désirée Schyns. Amsterdam: De Bezige Bij, 2018.

Slauerhoff, J.J. Verzamelde gedichten 2. Den Haag: Stols, 1947. 



\title{
1.5. \\ Relatie tussen auteur en vertaler
}

\author{
Nicolette Hoekmeijer
}

Over de relatie tussen oorspronkelijk werk en vertaling, en daar direct aan gekoppeld de relatie tussen auteur en vertaler, is veel gezegd en geschreven, ook door auteurs zelf. Bij de uitreiking van de Europese Literatuurprijs 2017, aan auteur Max Porter en vertaler Saskia van der Lingen voor Verdriet is het ding met veren (2017), spraken beiden een dankwoord uit, dat is te lezen op de website van het Nederlands Letterenfonds. "Vertalen is een omhelzing", zei Saskia van der Lingen. Max Porter beaamde dat en vervolgde:

Vertalen is een vorm van en een stilzwijgend geloof in vriendschap (...). Een persoonlijk wiegelied onder handen nemen (...) en die tekst laten werken in een andere taal, laten zingen in een nieuwe context, dat is het radicaalste en tegelijk het basaalste, het meest vruchtbare, vakkundige, bezielde en wezenlijke wat iemand kan doen. ${ }^{1}$

David Mitchell liet zich in soortgelijke bewoordingen uit toen hij vertalers Harm Damsma en Niek Miedema - die onder meer werk van Mitchell hebben vertaald toesprak toen ze de Nederlands Letterenfonds Vertaalprijs in 2016 in ontvangst namen.

[Vertalen] is ook een vreemd soort intimiteit ... Er zijn maar weinig dingen zo hartstochtelijk als je relatie met je eigen taal, en jullie kennen mijn relatie met taal beter dan ikzelf, dat meen ik echt. Jullie doorzien hoe ik schrijf, jullie kennen mijn favoriete woorden, zien dingen die mij niet opvallen. (...) ik kan me geen

1 http://www.letterenfonds.nl/nl/entry/1838/vertaling-is-een-omhelzing, vertaling Saskia van der Lingen. Gezien 22-1-2019. 
twee Nederlandse heren indenken die ik liever door de krochten van mijn brein laat dwalen dan jullie. ${ }^{2}$

Ali Smith, over wie straks meer, zegt in een interview op de website Authors \& Translators ${ }^{3}$ " "Translators pretty much have to write the book anew and find a way to make it work in each language. I have huge faith in translators."

Deze schrijvers formuleren het allemaal anders, maar alle drie realiseren ze zich terdege dat ze het lot van hun geesteskind in handen leggen van hun vertaler, dat wij door de krochten van hun brein moeten dwalen om ons werk goed te doen.

\section{1.}

Als vertaler schep je een evenbeeld van de originele tekst, opgebouwd uit de materialen van je eigen taal en cultuur. Je zou brontekst en vertaling dan ook kunnen zien als twee zusterschepen: identiek maar niet hetzelfde. Dat beeld kun je doortrekken: ook auteur en vertaler zijn in zekere zin gelijkwaardig - ze scheppen elk een versie van dezelfde tekst - maar ze zijn niet identiek. De verbeelding waaraan de tekst is ontsproten, zowel op inhoudelijk als stilistisch niveau, is die van de auteur. De vertaler maakt zijn eigen taal, maar qua inhoud en stijl volgt hij de auteur. Daarbij verlaat hij zich op de tekst, de context, de taal, het oeuvre en de cultuur om de weg te vinden in eerdergenoemde krochten van het auteursbrein. Om de vertaling te kunnen 'schrijven' moet je dus weten, kunnen herleiden, begrijpen, achterhalen wat er in het origineel staat. Dat is je vakmanschap.

Maar soms zijn de aanwijzingen niet eenduidig, is de taal niet eenduidig, biedt de tekst onvoldoende houvast. Dan komt het aan op de verbeelding, op inleving, interpretatie, om erachter te komen wat de auteur voor ogen heeft gehad, wat precies de verbeeldingswereld is waaruit de beelden, en vervolgens de woorden, zijn ontsproten. Alleen dan kun je in je eigen taal de overeenkomstige beelden en woorden vinden. Ook dát is je vakmanschap.

Echter niet in alle gevallen zullen tekst, context, (culturele) kennis, kennis van de taal, wellicht kennis van het oeuvre of zelfs kennis van de persoonlijke

2 https://www.tijdschrift-filter.nl/webfilter/vrijdag-vertaaldag/2017/week-17-david-mitchell/, vertaling Marije Kok, gezien 22-1-2019.

3 http://authors-translators.blogspot.com/2014/11/ali-smith-and-her-translators.html, gezien 22-1-2019. 
omstandigheden van een auteur, in combinatie met je intuïtie, voldoende houvast bieden. Soms blijf je twijfelen of je de tekst, de bedoeling van de auteur, juist interpreteert.

Wie een dode auteur vertaalt heeft die luxe niet, maar wie een levende auteur vertaalt, heeft dan de mogelijkheid bij hem of haar te rade te gaan.

\section{2.}

Voor Paula Stevens \& Edith Koenders, die samen met auteur Johan Harstad de Europese Literatuurprijs 2018 hebben gewonnen met Max, Mischa \& het Tet-offensief (2017), namen de krochten een vrij concrete vorm aan. Zij hebben hun auteur letterlijk om een plattegrond gevraagd, vertellen ze in hun lezing voor de Vertalersgeluktournee $2018^{4}$ :

Ondanks alle mooie plaatjes kregen we maar geen beeld van het appartement waar het om ging - in de tekst was bijvoorbeeld sprake van een verwarrende hoeveelheid halletjes en een zuilengalerij - hoe zag dat eruit? Pas toen Harstad de plattegrond stuurde die hij zelf had gebruikt, vielen de dingen op hun plaats en konden we tot een goede beschrijving komen.

Algemene richtlijnen zijn moeilijk te geven, maar als je echt lijkt te verdwalen, als je onvoldoende wegwijzers weet te vinden voor een zogeheten educated guess, ga dan niet op hoop van zegen gokken en hineininterpretieren. Neem contact op met je auteur - de enige die echt uitsluitsel kan geven. Over het algemeen zal een auteur graag willen helpen, hij is er alleen maar bij gebaat dat zijn stem zo goed mogelijk wordt verwoord.

Maar denk wel goed na over wát je vraagt. Op 18 februari 2014 gaf Margaret Atwood in de British Library in Londen de jaarlijkse Sebald-lezing, 'Atwood in Translationland', waarin ze onder meer vertelde hoe het is om vertaald te worden. ${ }^{5}$ Ook Atwood is vol lof over haar vertalers, maar ze laat zich ook kritisch uit over

4 http://www.letterenfonds.nl/images/2018-o9/lezing-edith-koenders--paula-stevens.pdf, gezien 22-1-2019.

5 https://www.youtube.com/watch?v=D4_K3EkPHr4, gezien 22-1-2019. 
vertalers die domme vragen stellen - uit luiheid, een gebrekkig gevoel voor de tekst, onvoldoende besef van de context:

Ik heb in de loop der jaren heel wat avonturen met vertalers beleefd. "Is dit grappig, of is het niet grappig?" is me gevraagd. 'Allebei' valt moeilijk uit te leggen. "Ah, Angelsaksische humor!" heb ik ze dan wel horen zeggen; waarmee ze "macabere humor' bedoelden, denk ik. "Wat is granola?" vroeg mijn eerste Chinese vertaler. "Wat is een Smile Button?" En als ze niet wisten wat granola was, wat wisten ze dan misschien nog meer niet, zonder te weten dat ze het niet wisten?

De boodschap lijkt duidelijk: vraag je schrijver alleen om hulp, raad, advies, nadere toelichting als je er echt met geen mogelijkheid (lees: woordenboeken (meervoud!), internet, collega's, native speakers, vrienden, specialisten, leken, vraagbakens, naslagwerken, mailinglisten, lang en diep nadenken etc.') zelf achter kunt komen wat er staat of wordt bedoeld. Je auteur is nadrukkelijk niet je co-vertaler, met wie je over van alles en nog wat kunt sparren.

\section{3.}

Dat het contact met vertalers ook heel anders kan lopen dan in de voorbeelden die Atwood geeft, bewijst de eerdergenoemde Ali Smith. In The New Yorker van 29 januari 2018 schrijft James Wood:

The Scottish writer Ali Smith is surely the most pun-besotted of contemporary novelists, edging out even Thomas Pynchon. It's not simply that she loves puns; it's that she thinks through and with them; her narratives move forward, develop and expand, by mobilizing them. ${ }^{8}$

6 Vertaling Peter Bergsma, voor de Groene Amsterdammer, april 2014, \#14.

7 Zie ook 1.4.

8 "Er is geen hedendaagse schrijver die zo dol is op woordspelingen als de Schotse Ali Smith - ze steekt zelfs Thomas Pynchon naar de kroon. Het is meer dan alleen een voorliefde - Smiths hele denken voltrekt zich in en via woordspelingen, ze gebruikt ze om haar verhaal vaart te geven, uit te bouwen en diepte te verlenen" (mijn vertaling). 
In het geval van Smith volstaat het dan ook niet om de woordspelingen enkel in talige zin overeind te houden - ook de inhoudelijke verwijzingen moet recht worden gedaan. In de meeste gevallen zul je daarvoor als vertaler behoorlijk wat vrijheid moeten nemen. ${ }^{9}$ Smith-vertalers Karina van Santen en Martine Vosmaer hebben Smith al in een vrij vroeg stadium van hun vertaling van Autumn (2017) benaderd met de vraag of ze zich, waar nodig, enige vrijheid mochten permitteren. Geen enkel probleem. Smith begrijpt heel goed wat vertalen behelst, zoals ook blijkt uit het eerdergenoemde interview op Authors \& Translators, waar zij over vertalers zegt:

They have a hard job with my books, which are all about language texture, are full of word play and are only about plot in the last instance - I think they pretty much have to write the book anew and find a way to make it work in each language. (...) I feel in safe hands with translators generally! $!^{10}$

Toch leek er een grens te zijn aan de inschikkelijkheid van Smith. Een van de hoofdpersonen in haar roman heet Elisabeth Demand - een achternaam die naast de Engelse betekenis ('eisen', 'verlangen' of 'nodig hebben') puur vanwege de klank ook wordt gekoppeld aan het Franse de/du monde. Maar die wereldse klankassociatie gaat alleen op als Demand op z'n Engels wordt uitgesproken. Van Santen en Vosmaer mailden Smith in de zomer van 2017 met de vraag of ze de naam mochten veranderen:

We've encountered a rather unsurmountable problem with Elisabeths surname. "Demand" has no meaning in Dutch and does not sound like "de/du monde" at all. Although we realise it would be a big intervention in such a carefully composed book, we would like you to consider allowing us to change the name throughout the whole book to "Demond". In Dutch, "Demond" means "the mouth" which would make it useable both for the scene at the post office $[. .$.$] as for Daniels remarks. { }^{11}$

9 Zie ook 2.4 en 2.6.

10 "Ik maak het ze niet makkelijk met mijn boeken, die gaan over de structuur van taal, die wemelen van de woordspelingen en waarin de plot vaak op de laatste plaats komt - ik denk dat ze het boek min of meer opnieuw moeten schrijven en een manier moeten zien te vinden waarop het werkt in elke afzonderlijke taal (...). Over het algemeen heb ik het gevoel dat ik bij vertalers in goede handen ben!” (mijn vertaling).

"We zijn op een vrijwel onoverkomelijk probleem gestuit met Elizabeths achternaam. Demand heeft geen betekenis in het Nederlands en klinkt heel anders dan de/du monde. We begrijpen dat het een grote ingreep is in een zo zorgvuldig gecomponeerd boek, maar willen toch vragen of we de naam in het hele boek mogen veranderen in Demond. In het Nederlands betekent dat 'de mond' en daarmee 
Een redelijk, respectvol, concreet en goed onderbouwd verzoek. Het was voor Smith echter een brug te ver, liet zij in een al even vriendelijke en respectvolle mail weten. "I'm going to suggest in this instance that you keep the name Demand and simply refer, like Daniel does, to it via French." ${ }^{12}$ Zo geschiede.

Toen Ali Smith in maart 2018 in de Amstelkerk in Amsterdam werd geïnterviewd door Liddie Austin, op een avond die door boekhandel Athenaeum was georganiseerd naar aanleiding van de verschijning van Winter (2018), kwam Smith zelf op dit voorbeeld terug. Tijdens Smiths bezoek aan Amsterdam hebben Vosmaer en Van Santen haar uitvoerig gesproken en ook de Demand-kwestie nog eens nader toegelicht. Het resultaat was dat de vertaalsters naar huis gingen met een gesigneerd exemplaar van Herfst (2018) met daarin een persoonlijke opdracht van Ali Smith, die haar grote waardering uitsprak voor de vertalers en hun carte blanche gaf om bij de vertaling van de volgende delen geheel naar eigen goeddunken te handelen.

Hier hebben de vertalers duidelijk vertrouwen gekweekt met een professionele instelling: door te laten merken dat ze hun vak verstaan en door constructieve en goed onderbouwde vragen te stellen, vanuit een begrip van, en respect voor, de tekst. Naarmate het vertrouwen groeit, neemt de speelruimte toe die de auteur hun gunt. Dit proces is diametraal tegengesteld aan de voorbeelden die Atwood gaf, waar de vertalers haar al bij het eerste contact tegen de haren instreken door luiheid, onbegrip of onkunde, met een afbrokkelend vertrouwen als gevolg.

\section{4.}

Het is altijd zoeken naar de juiste vorm, en die zal per auteur verschillen, maar mogelijk zijn er toch enkele algemene richtlijnen te destilleren. Neem om te beginnen zowel je auteur als jezelf serieus, realiseer je goed dat je auteur niet je co-vertaler is, dus vraag geen dingen die je ook zelf had kunnen bedenken/opzoeken/navragen, bouw een band op met je auteur zoals je dat ook in het gewone leven met mensen doet, stapsgewijs, door niet alleen te vragen maar vooral ook te luisteren, en van daaruit verder te gaan. Doseer je vragen ook enigszins - niet iedere auteur zal blij zijn

is die naam zowel bruikbaar voor de scène in het postkantoor (...) als voor Daniels opmerkingen" (mijn vertaling).

12 "Ik zou toch willen voorstellen dat jullie in dit geval vasthouden aan de naam Demand en, net als Daniel, de verwijzing gewoon via het Frans laten lopen” (mijn vertaling). 
met een dagelijkse waslijst aan vragen. Te overwegen valt om je auteur te benaderen zodra je aan de vertaling begint, met de vraag of je in de loop van het project wellicht wat dingen mag voorleggen. Het kan zinvol zijn om dan meteen te vragen wat de auteur het liefst heeft: mailen zodra je met een vraag zit, of alles opsparen tot het einde? Mijn voorkeur is zonder meer de laatste optie, aangezien de ervaring heeft geleerd dat veel vragen gaandeweg beantwoord worden, dat veel puzzelstukken als vanzelf in elkaar vallen.

Overigens zul je vaak via de Nederlandse uitgever aan het mailadres moeten zien te komen. Het komt de laatste jaren steeds vaker voor dat uitgevers het contact via henzelf en de agent van de auteur willen laten lopen. Naar ik begrijp heeft dat twee redenen: het is een methode om al te overdadig mailende vertalers enigszins af te remmen; en mocht de vertaler een 'fout' uit de tekst halen, dan is meteen de agent op de hoogte.

Al helemaal in dat laatste geval verdient ook de toon aandacht. Mocht je bijvoorbeeld je auteur op een vergissing 'betrappen', ga dan niet triomfantelijk van de toren blazen, maar vraag eerst (jezelf af) of er misschien een bedoeling achter zit, of er misschien een bepaald effect wordt beoogd, of de lezer misschien bewust op het verkeerde been wordt gezet. Druk je auteur niet in een hoek maar laat een respectvolle ruimte in je formulering. Op mijn vraag aan een schrijfster of er echt een jaguar in Afrika rondliep, of dat dit een luipaard moest zijn, kreeg ik een eenregelig antwoord: "Not everyone understands my Natasha-isms." Kennelijk had ik hier een verkeerde snaar geraakt.

Maar vaker heb ik leuke, nuttige, warme en informatieve reacties gekregen. Op zo'n manier kan er een band groeien met je auteur, een band die misschien zelfs weer op indirecte wijze kan bijdragen aan een beter begrip van de wereld die de auteur schetst, en daarmee misschien aan een betere vertaling. Ik heb een week met Nathaniel Rich opgetrokken en zijn hele manier van praten - snel, springerig, associatief, vernieuwend - maakte me duidelijk in welke richting ik het moest zoeken bij de vele opmerkelijke woordcombinaties in zijn tekst. Edward St Aubyn, met wie ik ook een persoonlijke band heb opgebouwd, uit zich volkomen anders: bedachtzaam, precies, dodelijk trefzeker, vilein, licht archaïsch. Op grond van onze ontmoetingen weet ik dat St Aubyn geen gelegenheid voorbij zal laten gaan om 'twee dingen tegelijk te verwoorden'. Waar zijn Melrose novels ruimte laten voor een keuze tussen een neutrale of een meer ironische vertaling, durf ik zonder scrupule de ironische stem in mij de vrije loop te laten. 
Door het contact met je auteur, in welke vorm ook, krijg je misschien niet meteen een handzame plattegrond à la Harstad aangereikt, maar op zijn minst zal er wat licht naar binnen kieren in de krochten waar wij als vertalers, soms op de tast, onze weg moeten vinden.

\section{Bibliografie}

Harstad, Johan. Max, Mischa en het Tet-offensief. Vertaald door Edith Koenders en Paula Stevens. Amsterdam: Podium, 2017.

Porter, Max. Verdriet is het ding met veren. Vertaald door Saskia van der Lingen. Amsterdam: Bezige $\mathrm{Bij}, 2017$.

Smith, Ali. Herfst. Vertaald door Karina van Santen en Martine Vosmaer. Amsterdam: Prometheus, 2018.

Smith, Ali. Winter. Vertaald door Karina van Santen en Martine Vosmaer. Amsterdam: Prometheus, 2018. 


\title{
1.6. \\ Vertolking 2.0 - Over het opnieuw vertalen van klassiekers
}

\author{
Barber van de Pol
}

1.

"Hoe ga je 'the watery part of the world' vertalen?"

Maarten Biesheuvel kijkt me bezorgd en beslist ook argwanend aan en dat is niet voor het eerst. Hij is een man van winterharde stokpaardjes en Moby Dick (1851), vindplaats van die 'watery part', is er één van. Sinds hij weet dat ik actieve bemoeienis met dat boek heb, zit hij me op de huid. Hij leerde het kennen in de vertaling van Emy Giphart (Melville [1961]) en die laat hij zich niet afpakken omdat ik zo nodig een nieuwe moet maken. Het is 2007. Begin volgend jaar komt mijn vertaling uit, er is nog tijd.

"Het waterige deel van de wereld", antwoord ik. Hoe anders?

Hij lijkt even opgelucht, maar dan schiet hem alweer iets te binnen.

"En 'Call me Ishmael'?"

Blijft een goede vraag, dat. Die drie eerste woorden zijn wel degelijk een probleem bij het vertalen van Melville's klassieker. In het Engels zijn ze gevleugeld en ik wil mijn Nederlands net zo'n vliegende start geven. De mogelijkheden spoken door mijn hoofd. Lang overwoog ik "Heet mij Ismaël”, dan heb je de passende oudtestamentische toon en Neeltje Maria Mins beroemde dichtregel resoneert gratis mee. Ik vertelde het mijn redacteur Jan Kuijper, die andere kritische vriend, die vaak "Vooruit dan maar" zegt, maar nu bedenkelijk had gekeken.

Het klinkt te literair. Misschien is te literair geen goed visitekaartje.

Wat te doen? "Zeg maar Ismaël" is tof, "Ismaël is de naam" is stijf en slaat nergens op. Ik meen het boek goed te kennen: de verteller is een profeet maar ook, net als de hoofdpersoon, de wraakzuchtige kapitein Achab, een geplaagde. Hij zal als enige opvarende van de Pequod overleven. Kijk de Bijbel en het boek er maar op na.

"Noem me Ismaël", zeg ik. 
Vriend knikt. Ja, dat heeft Emy Giphart ook (1961: 5), maar dat is precies waarom ik me bij voorbaat ongelukkig voel bij die oplossing. Hij denkt toch niet dat ik die van haar heb overgenomen? Dat taaluitingen een definitieve status hebben? Taal is altijd vertaling, wat je ook pretendeert weer te geven. Taal is interpretatie en parafrase; ze heeft intrinsieke waarde, geen absolute. Daar schreef Carry van Bruggen (1925) al over voordat Derrida het deed. Maar het klinkt ingewikkeld, dus ik houd mijn mond.

Ach Maarten, zal ik denken als ik 's avonds naar huis rijd, het levende boek waar ik voor ga moet overtuigen, niet storen. Je vragen beschuldigen me: ik zit niet alleen met mijn tengels aan andermans werk, zoals iedere vertolker, maar lijk ook nog eens de aanrander van mijn voorgangster, die ik juist mijd, maar dat terzijde. Nieuwe vertolkingen bij muziek of theater zijn gewoon, in de literatuur ligt dat anders.

Eigenlijk ben je net als bijna iedereen bij een vertaling belust op fouten, op vondsten eventueel, terwijl ik jou niet hoef te vertellen dat het daar bij zoiets complex en organisch als schrijven of herschrijven niet om gaat. In plaats van argwanend te zijn zou je je kunnen afvragen hoe de vertolker (ík, Maarten) zich tot het oorspronkelijke werk verhoudt. Wat heb ik geprobeerd, hoe komt het over? Dat telt bij oorspronkelijk werk en net zo goed bij een eerste, tweede, derde vertolking.

Angst voor fouten is dom. Leve de betrekkelijke argeloosheid waaruit iets onverwachts kan bloeien, om met Dick Hillenius (1996) te spreken.

Een vertaler breekt een boek af en bouwt met eigen materiaal een nieuw boek: hetzelfde anders. In die fase lijkt hij op de oorspronkelijke schrijver die ook uit een wirwar voornemens, sensaties en vermoedens eenheid creëerde. Door dichters worden vertalingen vaak opgenomen als eigen poëzie, zie recentelijk Joost Baars (2017) met zijn vertalingen van Gerald Manley Hopkins. Bij poëzie is de nood aan vrijmoedigheid om 'in de geest van' iets goeds te maken nog evidenter.

'Verzielen' noemt Hans Boland, eerste of zoveelste vertolker van Russische klassiekers, vertalen. De ene taal is de andere niet, vandaar ver-talen. De ene mens is de andere niet, vandaar ver-zielen. Uit de keus van zo'n woord blijkt Bolands hekel aan modellen. Hij is zijn eigen model. Vertalen kun je net zo min als schrijven leren, en ook moed of drang is niet te leren. Wel leer je van het voorbeeld van anderen, die sympathie of aversie wekken. Je leert je allergieën profileren en je eigenaardigheden koesteren. Dat houd ik mijn studenten creative writing als het hoogst haalbare voor. 


\section{2.}

In Mobydickiana (2009), Slibreeks nr. 128, vertel ik wat er zoal door mijn hoofd ging terwijl ik zocht naar de juiste woorden voor mijn Moby Dick (Melville 2008, 60o p.), en ook naar de juiste muzikale ondertoon en filosofische impact. Een boek is geen opstel dat op betekenis drijft.

Een fijne fase is dat, wikken en wegen, omarmen en verwerpen, proberen en op drift raken, maar ooit is die tijd van onschuld voorbij. Er moeten knopen doorgehakt en darlings vermoord, waarna het boek van de lezer en de literatuur is, zoals Borges het zei, en ik het loslaat, want anders dan een kind moet een geesteskind meteen op eigen benen staan. Vervolgens is het wat de gek ervoor geeft. Wordt het een publiekslieveling, een winkeldochter? Totdat de tijd z'n minder vluchtige oordeel velt. Moby Dick bleef een halve eeuw een flop en zit nu stevig in de canon.

Intussen begrijp ik mijn vriend best. In het vragenkwartier na een van de vele lezingen die ik sinds 1997 over mijn Don Quichot (Cervantes Saavedra 1997) heb gegeven, vroeg een vrouw of $i k$ het niet erg vond dat ze de eerdere vertaling van de hispanist Van Dam en de dichter Werumeus Buning (Cervantes Saavedra 1941-1943) mooi bleef vinden. "We hebben er zo van genoten, mijn man zaliger en ik."

Alsof ik daar in kan of wil treden! Wat een misverstand! Ik vertaal niet uit competitie, ik wil míjn vertolking van een innig geliefd boek geven, met alles wat daar aan emotie en ervaring bij komt. Laat ik het samenvatten: Werumeus Buning kón niet kleurloos zijn, hij is bewonderenswaardig flamboyant, maar ik ben hem niet. Ik ben loyaal aan míjn lezing. Een vertaling of vertolking sluit trouwens nooit andere uit, al was het maar omdat het origineel ligt te wachten op iedereen die de krachtmeting wil aangaan.

Het ontroerendst was dat de vragenstelster later langs mijn tafeltje kwam voor een handtekening.

\section{3.}

Je voelde de publieke verwarring en opwinding toen in 2004 de Nieuwe Bijbelvertaling van het NBG uitkwam. Ik was als een van de meelezers door het Genootschap gevraagd lezingen over de literaire kant te geven, terwijl een deskundige/vertaler zíjn verhaal deed. Het ging om een drietrapsproject: door theologen en andere wetenschappers was graaf- en speurwerk verricht, waarna de vertalers aan de slag 
gingen; tot slot mocht een leger schrijvers amenderen. De vertaling was direct uit de drie bronteksten gemaakt, geen sprake van een hervertaling of bewerking. Resultaat: verbetering van duizenden fouten of onduidelijkheden en de omverwerping van evenzovele heilige huisjes. Er was klare taal gebezigd in plaats van een mix van oud en gedragen, want dat zou berusten op misplaatste trouw.

Sommige gelovigen noemden het blasfemie dat er met kritische zin aan Gods Woord was gezeten. Voor hen gold de Statenvertaling of een afgeleide als het woord van God, alsof Hij/hij over pen en papier of een secretaresse beschikte. Alsof Hij/hij Aramees, Oudgrieks en Hebreeuws sprak of, als eigen vertolker in het Nederlands, een soort Vondeliaans. "In den beginne was het Woord." "Het geschiedde in die dagen." Zo hoorde het! Maar zo was het niet meer. De kribbe was nu een voederbak.

In het ontstaansverhaal van de Bijbel was niet iedereen geïnteresseerd. Geloof is blind en kennis tast het aan, wist ook Don Quichot als hem werd gevraagd naar een bewijs voor het bestaan van zijn aanbeden Dulcinea.

Natuurlijk waren er ook die 'voederbak' domweg lelijker vonden dan 'kribbe' en verheven nu eenmaal beter vonden passen bij het Woord dan gewoon. De onttovering was te groot. Overigens is de vertaling ongelijk van kwaliteit. Boeken als Job en Prediker hadden misschien betere meelezers, maar de ongelijkheid zit al in het origineel. Iets heel goeds daagt uit tot iets heel goeds, een zes zal niet snel een tien worden.

Het signaal is in al dit soort gevallen hetzelfde: aan verandering geen boodschap. Ook toen Gerard Koolschijn Oudgriekse lievelingen van hun negentiende-eeuwse projecties ontdeed en gangbare taal boven mooischrijverij verkoos, was er naast gejuich verontwaardiging. Onze bakermat van de beschaving leek ineens wel oosters!

Móét een nieuwe vertaling bij klassiekers om de zoveel tijd, zeg om de vijftig jaar? Nee. Waarom zou een oorspronkelijke tekst minder snel verouderen dan een oorspronkelijke vertaling? De Duitse Don Quichot-vertaling (Cervantes Saavedra 1799-1801) van Ludwig Tieck was tot voor kort de enige leverbare. Omdat hij goed was. Omdat Tieck goed is. Omdat er geen betere voorhanden was. Hoe ook: verschillende vertalingen kunnen naast elkaar bestaan, al zal er altijd eentje bovendrijven. Het is weelde. Klassiekers zijn vrij van auteursrechten. Hou je niet in als je de kriebels krijgt.

Het is behoudzucht om bij een nieuwe vertaling van een boek te spreken van 'hertaling'. Een 'hertaling' is aan de orde als iets in dezelfde taal is aangepast, en dan dus niet alleen qua spelling of interpunctie. In alle andere gevallen is gewoon sprake van een vertaling, een nieuwe vertaling van iets wat eerder was vertaald. Je mag immers hopen dat die niet leunt op de oude, laat staan er een aftreksel van 
is. Een interessant geval is Martinus Nijhoff, die, mogelijk uit schroom, koos voor een wonderlijk hybride vorm om Hoofts Historiën toegankelijker te maken: hij wisselende samenvatting af met stukken oorspronkelijke tekst (Hooft 1947). Later, in 1960, kwam er toch een hertaling, van A.C. Niemeyer en F.J. Schmit (Hooft 1960).

Hertalen is een schone zaak, zie hoe Jan Kuijper liederen van Hadewijch 'herdichtte' (Hadewijch 2010), maar op het hertalen van redelijk recent erfgoed valt wel wat af te dingen. Was het nodig Max Havelaar nu al onder handen te nemen, zoals Gijsbert van Es (Multatuli 2010) deed? En dan die verouderd geachte kinderboeken. Je kunt de stoof uit Pinkeltje halen omdat kinderen van nu niet meer weten wat een stoof is, maar kinderen weten zoveel niet. Hier speelt net zoiets als bij het gebruik van voetnoten omdat de lezer iets niet zou weten. De lezer weet zoveel niet, de context biedt meestal uitkomst en een roman is geen leerboek. Een voetnoot in een literaire tekst is akelig willekeurig en belerend.

In De autonauten van de kosmosnelweg zette Julio Cortázar één wijsneuzige voetnoot. Hij schreef er tussen haken bij: "Noot van de vertaler, een kei in vogels" (Cortázar 1986: 272). Ik kan de grap waarderen, maar zouden er lezers zijn die echt denken dat hij van mij is?

\section{4.}

Don Quichot (1605/1615) is een van die oorspronkelijke boeken die zich als vertaling voordoen. Het zou gaan om een document dat in hoofdstuk 8, dat iconische over het gevecht met de windmolens, ineens stopt. Gelukkig hoort de bezorger op een markt iemand lachen en zijn vermoeden blijkt juist: het gelach betreft de rest van het document, op naam van de Arabische historicus Sidi Hamid Benengeli. Tegen betaling van een baal rozijnen komt er een Spaanse versie en die, aangevuld met kanttekeningen van de schimmige bezorger, vormt het boek. Al die ongein hoort bij Cervantes' spel met de waarheid of liever de goedgelovigheid van zijn lezers (en personages). Het boek is zo relativerend en modern, dat het onder je ogen in wording lijkt.

In Cervantes \& co, in plaats van voetnoten (200o) doe ik verslag van de specifieke problemen waar ik als vertaler van deze anti-roman op stuitte. Een van de lastigste: hoe eer je je voorgangers? Sommige oplossingen hebben Van Dale gehaald, wat doe je met die erfenis? Zonder rücksichtslos te willen zijn: was iets verkeerd geïnterpreteerd 
of foutief overgenomen uit een andere vertaling, dan sneuvelde het. En zo ging de titel, de beroemde eerste zin en het bekendste epitheton van de Don op de schop.

Bijna iedereen heeft het geslikt, maar niet altijd bewust. Zo prees een recensent mijn vertaling met vermelding van het epitheton 'de ridder van de Droevige Figuur', een taaie fout. Ik bloosde haast toen ik in de ondertiteling bij The Man Who Killed Don Quixote (2018) mijn 'Droeve Gelaat' tegenkwam, zoveel juister, maar minder mooi. U ziet dat niet; u ondergaat de kracht van het origineel; dat krijgt niemand stuk.

\section{5.}

Ik ben kennelijk een typische tweede (of derde of vierde) vertaler, of misschien ben ik gewoon dol op bepaalde klassiekers. Ook van Borges heb ik werk vertaald dat eerder was vertaald, bijvoorbeeld, samen met Maarten Steenmeijer, al zijn gedichten, from scratch natuurlijk. Een deel was al eens door Robert Lemm vertaald en wat niet kon uitblijven gebeurde: onze vertalingen werden vergeleken. In NRC oordeelde Marjoleine de Vos (23 september 2011) dat beide goed waren; ze hield van de vorige, aan de nieuwe zou ze wennen.

Wat ze niet opmerkte was het enorme verschil. Bij ons is Borges een vormvaste speler of scepticus; bij Lemm rijmt hij niet en lijkt hij steeds uit op waarheid.

De meeste mensen lezen wat ze willen zien, maar dat zal ons, diehard close-readers, niet zo makkelijk meer lukken. Wat dat betreft zijn we de argeloosheid voorbij.

\section{Bibliografie}

Baars, Joost. Binnenplaats. Amsterdam: Van Oorschot, 2017.

Boland, Hans. Hij kan me de bout hachelen met zijn vorstendommetje, over Anna Karenina en de kunst van het vertalen. Amsterdam: Pegasus, 2017.

Borges, Jorge Luis. Alle gedichten. Vertaald (met verantwoording) door Maarten Steenmeijer en Barber van de Pol. Amsterdam: De Bezige Bij, 2015.

Cervantes Saavedra, Miguel de. Don Quichot. Vertaald (met verantwoording) door Barber van de Pol. Amsterdam: Athenaeum Polak \& Van Gennep, 1997.

Cervantes Saavedra, Miguel de. De geestrijke ridder Don Quichot van de Mancha. Vertaald door Johan Willem Frederik Werumeus Buning en Cornelis Frans Adolf van Dam. Amsterdam: Querido, 1941-1943. 
Cervantes Saavedra, Miguel de. Leben und Thaten des scharfsinnigen Edlen Don Quixote von la Mancha. Übersetzt von Ludwig Tieck. Berlin: Johann Friedrich Unger, 1799-1801.

Cortázar, Julio \& Carol Dunlop. De autonauten van de kosmosnelweg: of een tijdloze reis Parijs-Marseille. Vertaald door Barber van de Pol. Amsterdam: Meulenhoff, 1986.

Hadewijch, Liefdesliederen. Vertaald door Jan Kuijper. Amsterdam: Athenaeum-Polak \& Van Gennep, 2010.

Hillenius, Dick. De hand van de slordige tuinman. Amsterdam: Van Oorschot, 1996.

Hooft, P.C. Nederlandse historiën in het kort. Samengesteld door Martinus Nijhoff. Amsterdam/ Brussel: Elsevier, 1947

Hooft, P.C. Uit de Nederlandse Historiën van P.C. Hooft. Bijeengebracht en bewerkt door A.C. Niemeyer en F.J. Schmit. Amsterdam: Meulenhoff, 1960.

Melville, Herman. Moby Dick. Vertaald door Emy Giphart. Amsterdam: L.J. Veen's Uitgeversmij N.V., [1961].

Melville, Herman. Moby Dick. Vertaling (met verantwoording) door Barber van de Pol. Amsterdam: Athenaeum Polak \& Van Gennep, 2008.

Multatuli. Max Havelaar: of de koffieveilingen van de Nederlandse Handelmaatschappij. Hertaald en bewerkt door Gijsbert van Es. [Rotterdam]: NRC Boeken, 2010.

Van Bruggen, Carry. Hedendaagsch fetischisme. Amsterdam: Querido, 1925. Tweede druk 1948, met een voorwoord van Annie Romein-Verschoor. Derde druk 1980, met hetzelfde voorwoord, maar nu onder de titel Hedendaags fetisjisme.

Van de Pol, Barber. Cervantes \& co, in plaats van voetnoten. Amsterdam: Querido, 20oo. Aangevulde herdruk Amsterdam: Vertalers Vakschool, 2015.

Van de Pol, Barber. Mobydickiana, Slibreeks nr. 128. Middelburg: Stichting CBK Zeeland, 2009.

Vos, Marjolein de. "Wij zijn de tijd.” NRC (23 september 2011). Te raadplegen via https://www.nrc. nl/nieuws/2011/o9/23/wij-zijn-de-tijd-12036753-a960287. 



\section{7. \\ Duovertalen}

\section{Niek Miedema \& Harm Damsma}

Dit hoofdstukje gaat over duo-vertalen. Dat wil zeggen vertalen met zijn tweeën. Laten we beginnen met het uit de wereld helpen van een zelfs onder uitgevers volop levend misverstand, namelijk dat als je twee personen op een vertaling zet, het werk dan sneller af zal zijn. Dat geldt alleen maar als beide vertalers de helft van het boek voor hun rekening nemen en zich verder niet met elkaars werk bemoeien. Dan doen ze gewoon allebei een half boek en is er eigenlijk helemaal geen sprake van een duo-vertaling.

In principe zou een uitgever die haast heeft dan net zo goed drie vertalers kunnen nemen en die alle drie een derde van het boek laten doen, of vier die alle vier een kwart voor hun rekening nemen. Of tien vertalers, die allemaal een hoofdstuk doen, dan is een boek van achthonderd pagina's in een maand gepiept. En het treurige is dat dat soms nog gebeurt ook. Volkomen terecht verstrekken de Nederlandse en Vlaamse Letterenfondsen dan ook geen werkbeurzen voor dit soort projecten. Tientallen, viertallen of trio's komen niet in aanmerking. En duo's alleen wanneer er sprake is van een zinvolle samenwerking, die bij de aanvraag moet worden toegelicht. Gelegenheidsduo's hebben daarbij meer uit te leggen dan vaste koppels. Een aantal bekende vaste vertaalduo's zijn bijvoorbeeld Patty Krone en Yond Boeke, Karina van Santen en Martine Vosmaer, Robbert-Jan Henkes en Erik Bindervoet.

Er zijn ook mensen die het juist leuk vinden om telkens met een andere partner een verbintenis aan te gaan en per boek een vers duo te vormen, al naar gelang wat de tekst vraagt. Een voorbeeld hiervan is Gerda Baardman, die op deze manier al heel wat beginnende vertalers aan een eerste publicatie heeft geholpen.

We willen niet beweren dat met zijn tweeën vertalen altijd een beter eindresultaat oplevert dan wanneer je het alleen doet. Er zijn aan duo-vertalen allerlei voordelen en nadelen verbonden. Daarover later meer. 
Om te beginnen willen we een voorbeeld geven van de typische werkwijze van een duo. Stel, je hebt een roman gekregen van gemiddelde moeilijkheidsgraad, die 120.000 woorden lang is. Die lezen de vertalers eerst allebei en dan schrijven ze vast wat dingetjes op die door het hele boek terugkomen. Bijvoorbeeld sociaal-cultureel bepaalde realia. ${ }^{1}$ Verder kun je je gedachten laten gaan over de vraag hoe je frequent voorkomende zaken of begrippen gaat noemen, of je bepaalde mensen $\mathrm{u}$ of jij tegen elkaar laat zeggen, of de Acting Director Plaatsvervangend Directeur of Waarnemend Directeur moet heten, of je de namen van pubs die een duidelijke betekenis hebben wilt vertalen of in de brontaal (in dit geval van pubs natuurlijk het Engels) wilt laten staan enzovoort.

Dit soort beslissingen zijn technisch van aard, maar het is ook beslist zinvol om tevoren je persoonlijke perspectief op boek en personages met elkaar te bespreken, als in een soort tweepersoons boekenclub. Daarbij geef je je gezamenlijk rekenschap van wat de auteur volgens jou beoogt, en welke stijl- of andere middelen hij of zij daartoe inzet. En laten we eerlijk zijn: doorgaans is niet alles wat een auteur doet voor de volle honderd procent geslaagd. Wat te doen met al te wilde beeldspraak of particuliere eigenaardigheden? Uiteraard is de brontekst heilig in die zin dat de vertalers niets mogen herschrijven en niet redactioneel mogen ingrijpen. In 2015 was het thema van de jaarlijkse Literaire Vertaaldagen 'Verzinnen wat er staat'. Dat was een opzettelijk prikkelende noemer. Maar in de praktijk blijkt telkens weer dat het in feite vaak neerkomt op zo 'verzinnigen wat er staat'. En dat is, als het goed is, de vrucht van een heldere, eensgezinde kijk op het werk, die tevoren is doorgesproken. Neem hier een week voor, ofwel vijf werkdagen. Dat is dan Fase 1.

Vervolgens hakken we het boek doormidden. Het telt 120.000 woorden, dus ieder krijgt 60.000 woorden te vertalen. Reken op gemiddeld 1500 woorden per dag. Dat is dan ieder veertig werkdagen. Het vertalen van de eerste versie kost in dit voorbeeld dus acht weken fulltime. Dit is Fase 2.

Daarna volgt Fase 3 en dat is het bekijken van elkaars werk. ${ }^{2}$ Dit komt er, als het goed is, op neer dat de vertalers elkaars werk tot op de grond toe proberen af te breken. Dit klinkt onheilspellend, en is soms voor de ontvanger van de correcties niet per definitie een feestje, maar het is een noodzakelijk kwaad. Elke zin van de toegezonden vertaling wordt met de brontekst vergeleken. Correcties worden voorgesteld,

1 Zie ook hoofdstuk 2.2.

$2 \quad$ Zie ook 4.1. 
suggesties worden gedaan, fouten worden verbeterd. Een frisse, onbevooroordeelde corrector (je vertaalpartner) haalt er toch altijd weer heel veel uit waar je zelf een blinde vlek voor bleek te hebben. Voor Fase 3, het bekijken van elkaars werk, heb je bij een boek van gemiddelde moeilijkheidsgraad, waarbij ieder 60.000 vertaalde woorden van de ander moet bekijken, ongeveer twintig werkdagen nodig. Ongeveer de helft dus van de tijd die voor het vertalen ervan nodig is geweest. We rekenen op vier weken. Dat was Fase 3.

Fase 4 is het uitwisselen van de wederzijdse correcties. Beide vertalers bekijken deze, en registeren wat de ander aan fouten heeft gevonden en aan suggesties heeft gedaan. Enkele aperte fouten vind je natuurlijk zelfs bij een ervaren vertaler altijd wel, maar negentig procent van de verbeteringen zal toch, als het goed is, van cosmetische aard blijken. Dat wil zeggen: zinnen zijn mooier gemaakt, of lopen in de geopperde versie soepeler, en er zijn op allerlei plaatsen passender synoniemen gevonden. Het aardige is dat je juist door de vertaling van de ander als basis te nemen op iets beters kunt komen dat in dezelfde lijn ligt. Dat gaat vreemd genoeg gemakkelijker dan wanneer je je eigen vertaling nog eens doorloopt. Dan beland je vaak onbewust toch weer in hetzelfde spoor.

Maar in sommige gevallen zal de duo-vertaler ook merken dat zijn of haar compagnon de vinger op een zere plek heeft gelegd, zonder zelf meteen een elegante oplossing voor het probleem paraat te hebben. Dan kan het gaan om de vraag wat er precies staat in de brontekst, wat er mogelijk geïmpliceerd wordt, of de brontekst wel helemaal zuiver op de grammaticale graat is enzovoort.

Eigenlijk zou een persklaarmaker bij een uitgeverij dit moeten doen, en die let ook wel goed op het Nederlands, maar een groot voordeel van de kritische blik van de medevertaler ten opzichte van de persklaarmaker is dat de vertaler de brontaal doorgaans beter beheerst en dus ook echt de vertaling kan controleren, en niet alleen het Nederlands. De persklaarmaker (uiteindelijk ook beslist niet te versmaden) komt in een later stadium natuurlijk sowieso nog aan de beurt. ${ }^{3}$ Naast het verbeteren van duidelijke fouten en het aanbrengen van allerlei cosmetische verbeteringen, komt er bij het bekijken van het werk van de ander altijd nog een derde soort opmerkingen bovendrijven. Dat zijn de dingen waar je het omineuze woordje: BESPREKEN! bij zou kunnen zetten. Voor het bekijken van het commentaar op de 60.000 vertaalde woorden rekenen we twee werkdagen. Fase 4 vergt dus o, 4 week.

3 Zie ook 4.1. 
$\mathrm{Nu}$ komt de al met al leukste fase: Fase 5. Daarin gaan de duo-vertalers bij elkaar zitten en lopen ze alle knelpunten en bespreekpunten langs. Dat gaat dan om de dingen die in Fase 4 zijn aangegeven als bespreekgevallen en om de suggesties van de collega die de oorspronkelijke vertaler van dat deel liever niet wenst over te nemen. De discussies die hieruit voortvloeien duren voor een tekst van 120.000 woorden al gauw acht sessies ofwel acht werkdagen. Dan werk je per zitting iets van 15.000 woorden ofwel 50 boekbladzijden door. Dat is veel, maar het kan wel. Als er wordt uitgelopen op het schema, is het bijna altijd in deze fase.

Tijdens de discussies kom je ook altijd achter enkele zaken die je ook samen niet kunt oplossen. Dat wil zeggen: dingen die je niet zeker weet, dus waarvoor extra speurwerk moet worden gedaan, of waar mensen voor moeten worden geraadpleegd. Bij dit soort speurwerk moet je denken aan bijvoorbeeld dichtregels of liedjes die al eens vertaald zijn en die je moet opzoeken, of titels, of allerlei detailkennis, of heel specifiek jargon. Dan ga je bellen met bijvoorbeeld een wapenhandelaar over bepaalde vuurwapens uit de Amerikaanse Burgeroorlog, of met een cipier. ("Hoe zeggen jullie dat daar in de bajes nou precies?"). Die mensen vinden dat trouwens vrijwel altijd ontzettend leuk, en je krijgt ze soms niet meer stil als ze eenmaal zijn begonnen met hun uitleg. Dit soort naspeuringen is te beschouwen als huiswerk en wordt verdeeld over de vertalers.

Naast een lijstje met 'nazoeken' en 'navragen' zal in Fase 5, de bespreekfase, ook altijd een lijstje ontstaan met dingen in de tekst die het duo ondanks alle dappere beschouwingen niet helemaal snapt, of over de betekenis waarvan de twee het niet eens kunnen worden. Dat leidt tot een aantal vragen voor de auteur. ${ }^{4}$ Die reageert, uiteraard mits nog in leven en compos mentis, meestal heel behulpzaam en begripvol. De verdenking is zelfs gerechtvaardigd dat auteurs het prettig vinden erbij te worden betrokken, omdat ze voor de buitenlandse edities nu eenmaal overgeleverd zijn aan hun vertalers en ze op geen enkele manier kunnen controleren of de Noorse, Portugese of Japanse vertaling van hun werk een beetje deugt. Uit de vragen die aan hen gesteld worden zal dan hopelijk blijken dat de vertalers zorgvuldig te werk gaan en hart voor het boek hebben. Fase 5 vergt in ons voorbeeld 1,6 week.

Tot slot komt Fase 6, waarin ieder het bovengenoemde huiswerk doet, de auteur een lijstje met vragen krijgt en ieder voor het eigen deel van de tekst de correcties van de compagnon invoert, plus alle formuleringen waarover het duo het tijdens 
de onderlinge bespreking eens is geworden. Dat vergt tien werkdagen, ofwel twee weken. Daarna kan de tekst ingeleverd worden bij de opdrachtgever.

We kunnen de optelsom nu gaan maken.

$\begin{array}{ll}\text { Fase 1 (lezen en vooroverleg): } & 1 \text { week } \\ \text { Fase 2: (vertalen): } & 8 \text { weken } \\ \text { Fase 3: (wederzijds corrigeren): } & 4 \text { weken } \\ \text { Fase 4: (bekijken voorstellen): } & 0,4 \text { week } \\ \text { Fase 5: (besprekingen): } & \text { 1,6 week } \\ \text { Fase 6: (doorvoeren wijzigingen): } & 2 \text { weken }\end{array}$

In totaal komen we op $\mathbf{1 7}$ weken fulltime, ofwel een kleine vier maanden. Dat is dan een redelijk krap schema. Er moet niets tussen komen. Op de kalender beslaan die 17 weken wellicht meer dan vier maanden, want van literair vertalen alleen kun je niet altijd leven, dus menigeen doet er ook andere dingen bij.

Als je het boek alleen zou vertalen, in hetzelfde tempo van 1500 woorden per dag, zou je voor 120.000 woorden 80 werkdagen nodig hebben, of wel 16 werkweken. Maar je wilt ook dan het boek van tevoren lezen, al hoef je er niet over te overleggen om een strategie te bepalen en afspraken te maken. En je moet misschien ook de auteur aanschrijven of externe bronnen raadplegen. Dus tel er maar rustig een week bij op. En dan kom je ook uit op 17 weken.

Het bovenstaande is geen verplichte blauwdruk voor de werkmethode van een vertalersduo. Elk koppel zal er een eigen invulling aan geven. Sommige duo's hebben bijvoorbeeld de gewoonte elkaar de gehele tekst hardop voor te lezen, wat zeker een toegevoegde waarde kan hebben, maar ook weer tijd kost.

Er zijn een aantal duidelijke voordelen van duo-vertalen te onderscheiden:

1. Je hebt een groter fonds aan kennis. Twee weten meer dan één.

2. Je hebt een vangnet. Iemand kijkt naar je werk en haalt er dingen uit die je er zelf niet uitgehaald zou hebben. Iedereen heeft blinde vlekken.

3. Compensatie van je zwakkere kanten. Als het goed is, vul je elkaar aan.

4. Gezelligheid. Vertalen is in principe een eenzame bezigheid. Het spreken over je werk met iemand die met dezelfde kwesties worstelt is heel prettig. 
Er kleven ook onmiskenbare nadelen aan duo-vertalen:

1. Financiële. Je moet alle inkomsten delen, want het honorarium voor een vertaling wordt per woord berekend, en het aantal woorden van de brontekst staat vast, of je die nu alleen of met zijn tweeën vertaalt. Ook projectsubsidies van het Nederlands Letterenfonds en projectbeurzen van het Vlaams Fonds voor de Letteren worden op basis van het aantal woorden berekend en moeten worden gedeeld.

2. Mogelijke stijlbreuk. Elke vertaler heeft particuliere voorkeuren die vanzelfsprekend en ongemerkt in de vertaling terechtkomen. Het eindresultaat moet echter wel een eenheid zijn.

3. Afhankelijkheid van de ander. Als een van beide partners ziek wordt of om een andere reden in gebreke blijft, is het halen van de deadline in gevaar. Je zou kunnen zeggen dat het risico dat er iets misgaat bij twee vertalers dubbel zo groot is, maar je zou ook kunnen zeggen dat de vertaalpartner in geval van nood kan bijspringen.

Bovengenoemde voor- en nadelen zijn algemeen. Voor een succesvolle samenwerking moet echter ook nog aan een aantal voorwaarden worden voldaan. De eerste en misschien wel belangrijkste daarvan is dat je eenzelfde taalgevoel moet hebben. Als je merkt dat je niet dezelfde inschatting hebt van bijvoorbeeld het register van een woord, of de gebruiksfrequentie, of de gevoelswaarde, dan zul je niet gemakkelijk tot overeenstemming komen. De tweede is dat je tegen kritiek moet kunnen. De partner moet de volledige vrijheid hebben om jouw werk te becommentariëren en bekritiseren. Anders werkt het niet. De derde is dat je te allen tijde het belang van het eindresultaat groter moet vinden dan je eigen belang. De vierde is dat je afspraken moet nakomen. De ander moet van je op aan kunnen en wordt anders gedupeerd.

Ten slotte dit: de duo-vertaling is een product waar je beiden volledig achter moet staan. Eigenlijk moet je net zo lang doorgaan tot je het eens bent. Als je namelijk niet volledig achter het eindproduct staat, houd je er een onbevredigend gevoel aan over. Wederzijds compenseren in de geest van 'ach, de vorige keer heb ik mijn zin gekregen, nu ben jij aan de beurt' is uit den boze. Als je erin slaagt geheel of grotendeels aan deze voorwaarden te voldoen, heeft een duovertaling beslist meerwaarde en mag

$5 \quad$ Zie 1.1. 
je zelfs de droom koesteren dat je samen een betere vertaling hebt opgeleverd dan je ieder afzonderlijk zou hebben gedaan. En daar gaat het uiteindelijk om.

Tot slot volgen hier enkele namen van duo-vertalers: Erik Bindervoet en RobbertJan Henkes (J. Joyce 2016), Yond Boeke en Patty Krone (Cognetti 2017), Harm Damsma en Niek Miedema (Saunders 2017), Iannis Goerlandt en Daniël Rovers (Foster Wallace 2013), Edith Koenders en Paula Stevens (Harstad 2017) en Karina van Santen en Martine Vosmaer (Blas de Roblès 2011).

\section{Bibliografie}

Blas de Roblès, Jean-Marie. Middernachtsberg. Vertaald door Karina van Santen en Martine Vosmaer. Amsterdam: Ailantus, 2011.

Cognetti, Paolo. De acht bergen. Vertaald door Yond Boeke en Patty Krone. Amsterdam: De Bezige $\mathrm{Bij}, 2017$.

Harstad, Johan. Max, Mischa en het Tet-offensief. Vertaald door Edith Koenders en Paula Stevens. Amsterdam: Podium, 2017.

Joyce, James. Dublinezen. Vertaald door Erik Bindervoet en Robbert-Jan Henkes. Amsterdam: Athenaeum, 2016.

Saunders, George. Lincoln in de bardo. Vertaald door Harm Damsma en Niek Miedema. Amsterdam: De Geus, 2017.

Wallace, David Foster. De bleke koning. Vertaald door Iannis Goerlandt en Daniël Rovers. Amsterdam: Meulenhoff, 2013. 



\section{npol II}

Belangrijke

begrippen 



\title{
2.1. \\ Equivalentie in de vertaalpraktijk en de vertaalstudie
}

\author{
Henri Bloemen
}

\section{Norm en begrip}

De term equivalentie is zonder twijfel een van de meest centrale, maar tegelijkertijd ook een van de meest gecontesteerde termen in het spreken over vertalen. Om die dubbelzinnige situatie goed te begrijpen is het zinvol om binnen de term een onderscheid te maken tussen equivalentie als norm voor de vertaalpraktijk en equivalentie als vertaalwetenschappelijke begrip. Op beide velden - de vertaalpraktijk en het vertaalonderzoek - doorloopt de term een parcours van acceptatie en vervolgens problematisering, maar dat parcours kent in beide gevallen een ander verloop.

Vanaf de eerste vormen van het spreken over vertalen tot op de dag van vandaag geldt 'equivalentie' als een norm die de vertaalpraktijk stuurt: vanaf de eerste vertalingen die ertoe doen (de facto waren dat Bijbelvertalingen) werd van een vertaling verwacht dat ze op de een of de andere manier een gelijkwaardige weergave van het origineel was; en ook vandaag is de eerste reflex van vertalers het zoeken naar een zo equivalent mogelijke weergave van 'wat er staat'. Tegelijkertijd ervaart elke vertaler dat een volledig gelijkwaardige weergave een quasi onmogelijke opgave is. In de vertaalpraktijk mag men daarom spreken van een spanningsvolle verhouding ten aanzien van de norm 'equivalentie': men houdt eraan vast ondanks zijn praktische onrealiseerbaarheid.

In de beginperiode van het wetenschappelijk vertaalonderzoek - eind jaren vijftig van de twintigste eeuw - was het begrip 'equivalentie' nog min of meer vanzelfsprekend. De eigenlijke begripsgeschiedenis van 'equivalentie' begint pas rond die tijd, al bestond de idee van gelijkwaardigheid al veel langer. In de linguïstisch georiënteerde vertaalwetenschap diende 'equivalentie' als begrip 
om de relatie tussen origineel en vertaling te beschrijven, waarbij de 'waarde' van het origineel als maatstaf gold voor de 'waarde' van de vertaling. Vond in de vertaalpraktijk de problematisering van 'equivalentie' zijn oorsprong in de ervaren onmogelijkheid ervan, zo werd in het vertaalonderzoek eigenlijk vanaf de introductie van het begrip het problematische karakter ervan mee ingevoerd. Roman Jakobson, een van de grondleggers van het linguïstisch vertaalonderzoek, besluit in zijn "On Linguistic Aspects of Translation" (2004/1959) dat de equivalente weergave van een tekst problematisch, ja onmogelijk wordt zodra de talige vorm van de mededeling poëtische eigenschappen krijgt. Poëzie is volgens Jakobson onvertaalbaar - in de zin van vertaling als (betekenis-)equivalente weergave. Vanaf de jaren 70, in het descriptieve vertaalonderzoek, werd 'equivalentie' uit zijn centrale theoretische positie verdrongen en vervangen door het begrip 'verschuiving' of shift, dat geschikter geacht werd om de relatie origineel-vertaling te beschrijven. Die belangrijke paradigmawisseling betekent in feite de erkenning van de andersheid van een vertaling. Het afscheid van 'equivalentie' als begrip in de vertaalwetenschap heeft zich vooral voltrokken in het onderzoek naar de vertaling van niet-literaire teksten. In het literaire vertaaldiscours of in het spreken over de vertaling van zogenaamde 'gevoelige teksten' (Simms 1997) vindt het begrip tot op de dag van vandaag wel nog voorspraak, zij het vaak impliciet of onder andere benamingen.

In het Petra-E-referentiekader voor de opleiding van literair vertalers komt het begrip 'equivalentie' niet meer voor, maar dat betekent niet dat 'equivalentie' als norm bij het 'produceren van een doeltekst' (PETRA-E) uitgediend heeft. In het modelcontract voor literaire vertalingen, dat door de literaire fondsen in Nederland en Vlaanderen gehanteerd wordt, is wel nog sprake van een 'adequate weergave' van een brontekst - een van de synoniemen van 'equivalentie'.

In wat volgt willen we ingaan op 'equivalentie' als norm voor de vertaalpraktijk: waarom wordt van een vertaling verwacht dat ze equivalent is aan haar origineel en welke vormen van equivalentie hebben zich daarbij (ook historisch) ontwikkeld? In een tweede deel behandelen we het begrip 'equivalentie' in het vertaalonderzoek. We eindigen met een overzicht van de overlevingsvormen van 'equivalentie' op het snijvlak tussen norm en begrip. 


\section{Funderingen en vormen van equivalentie}

\section{Identiteit en formele equivalentie}

De idee dat een vertaling een precieze weergave van een anderstalige tekst dient te zijn is dus zo oud als het vertalen zelf. In het historisch vertaaldiscours figureert 'equivalentie' in hoofdzaak onder het synoniem 'trouw', maar ook onder termen als 'weergave', 'gelijkenis', 'nabootsing', 'kopie', 'overeenkomst' e.a. Het metadiscours dat het praktische vertalen al meer dan 2400 jaar begeleidt, legt daar getuigenis van af. Vanuit een historisch perspectief is het zo goed als onmogelijk om over het vertalen iets zinvols te zeggen zonder daarbij terug te grijpen naar de idee van een vertaling als een tekst die 'hetzelfde' zegt in een andere taal. De norm 'equivalentie' is daarmee een centraal bestanddeel van het op identiteit gebaseerde spreken over vertalen dat eist dat een afbeelding, een kopie, een representatie of een nabootsing identiek dienen te zijn of verregaande gelijkenis dienen te vertonen met het origineel. Die eis ligt aan de oorsprong van de zogenaamde formele equivalentie, waarbij een vertaling zoveel mogelijk de formele eigenschappen van de brontekst overneemt: de volgorde van de zinsdelen, de woordsoorten, zelfs de interpunctie. De meest radicale vorm van formele equivalentie is de interlineaire vertaling of, in mildere vorm, de woord-voor-woord-vertaling. Nauw verwant aan de formele equivalentie is de linguïstische equivalentie, die zich op eenheden onder het zinsniveau richt: woorden, zinsdelen, woordgroepen en collocaties, idiomatische uitdrukkingen, hoofd- en bijzinnen. Omdat woorden meerdere betekenissen kunnen hebben en collocaties en idiomatische uitdrukkingen in verschillende talen ander linguïstisch materiaal gebruiken, heeft men hier nog verdere onderscheidingen ingevoerd, zoals de totale equivalentie (een woord voor een woord), de overrepresentatie (één woord dat door meerdere andere equivalent weergegeven wordt), de nul-vertaling (geen equivalent) en andere.

\section{Equivalentie als basiseis - referentiële, functionele en communicatieve equivalentie}

Equivalentie vindt mede zijn grond in de pragmatische situatie waarin vertalen zich voordoet: een lezer die de taal van het origineel niet verstaat is aangewezen op een vertaling en mag als het ware van rechtswege verwachten dat de vertaling 'hetzelfde zegt' als het origineel. Een vertaler zal daarom steeds proberen om aan dat 
vermeende recht van de lezer tegemoet te komen. Die norm ligt aan de oorsprong van de zogenaamde referentiële of denotatieve equivalentie, waarbij in brontaal en doeltaal naar dezelfde referent in de werkelijkheid verwezen wordt. Maar hij vormt evenzeer het uitgangspunt voor enkele hedendaagse equivalentie-opvattingen zoals de functionele equivalentie en de communicatieve equivalentie. Bij de functionele equivalentie wordt eerst de functie van een brontekst of een passage bepaald en vervolgens wordt in de doeltaal, desgevallend met heel ander taalmateriaal, een tekst met dezelfde functie opgesteld. Communicatieve equivalentie is gericht op de transfer van de inhoudelijke betekenis van een boodschap. Dat is uiteraard een basisnorm van het vertalen, maar tegenwoordig spelen daarin ook culturele en ideologische factoren een belangrijke rol: een linguïstisch equivalente boodschap hoeft nog lang geen communicatief equivalente boodschap te zijn. Zowel de functionele als de communicatieve equivalentie verwijderen zich van het puur talige en grijpen naar 'afwijkende' formuleringen wanneer dat de functie of de communicatie ten goede komt. Hiervoor wordt tegenwoordig ook wel de term 'transcreatie' gebruikt.

\section{Equivalentie en de status van de tekst - formele vs. dynamische equivalentie}

Een derde fundering van 'equivalentie' is te vinden in de status van het origineel: hoe hoger de status van een brontekst, hoe absoluter de eis van equivalentie die aan een vertaling gesteld wordt. Dit is met name het geval bij de vertaling van zogenaamde 'heilige teksten'. De geschiedenis van de Bijbelvertaling bewijst dat: als de Bijbel 'Gods woord' is, dan kunnen aan de vertaling daarvan alleen maar de allerhoogste eisen gesteld worden. Wil een vertaling eveneens 'Gods woord' zijn, dan kan dat alleen als ze de perfecte afbeelding ervan is. Het christendom is die vertaaluitdaging aangegaan. Dat heeft aan de ene kant geleid tot heel strikte vormen van vertaling, waarbij woordvolgorde en concordantie in hoge mate gerespecteerd dienden te worden. Equivalentie werd hier gegarandeerd door verregaande letterlijkheid, wat de verstaanbaarheid niet zonder meer ten goede kwam. Aan de andere kant ontsnapte ook de Bijbelvertaling niet aan de vertalerservaring dat absolute equivalentie niet te bewerkstelligen is; die ervaring werd lange tijd geëscamoteerd doordat aan vertalingen de status van origineel verleend werd. De zogenaamde 'Vulgaat', de Latijnse vertaling van de Bijbel door Hiëronymus, diende katholieke bijbelvertalers tot in de twintigste eeuw als brontekst, want op het Concilie van Trente in 1546 was die tot origineel, dus tot totaal equivalente tekst, verklaard. In de protestantse wereld 
gold de Statenvertaling (1637) als 'Gods woord in het Nederlands' dat niet door een andere vertaling vervangen kon worden.

Er zijn heel wat parallellen tussen Bijbelvertalen en literair vertalen; in beide gevallen gaat het om de vertaling van 'gevoelige teksten' (Simms 1997), en dan speelt de zorgvuldigheid in de realisatie van equivalentie een belangrijke rol. De belangrijkste bijdrage van de Bijbelvertaling in de equivalentiediscussie is de verschuiving van de formele equivalentie naar de zogenaamde dynamische equivalentie (Nida 1964), waarbij het erom ging in de doeltaal 'het meest natuurlijke equivalent' te realiseren.

\section{Historische varianten van de equivalentienorm}

De eis dat er een relatie van equivalentie tussen brontekst en vertaling dient te zijn is een constante in de geschiedenis van het vertalen. Niettemin heeft die eis in de loop van de geschiedenis verschillende gedaantes aangenomen. Zo wordt over de Septuagint, de Griekse vertaling van de eerste vijf Bijbelboeken uit de derde eeuw voor Christus, de mythe verteld dat 72 vertalers elk apart aan de vertaling gewerkt zouden hebben en dat ze na 72 dagen allemaal dezelfde vertaling afleverden, die vanwege de klaarblijkelijke goddelijke inspiratie gelijkwaardig was aan de Aramees-Hebreeuwse brontekst. Dit is een mooi voorbeeld van aangenomen equivalentie, zoals we die vandaag ook kennen in landen met tweetalige wetgevingen, waar vertalingen van wetten per decreet voor equivalent verklaard worden.

De klassieke formulering van de equivalentienorm is te vinden bij Cicero in zijn De optimo genere oratorum ( $46 \mathrm{v}$. Chr.). Over zijn vertaling van de Griekse redenaars zegt hij:

Welnu ik heb deze teksten vertaald niet zoals een gewone vertaler ('ut interpres'), maar zoals een redenaar ('ut orator'), met behoud van zowel de oorspronkelijke gedachten als de redekunstige figuren en de beelden, maar dan met woorden die bij ons idioom passen. Ik vond het dus niet nodig om ieder afzonderlijk woord met een eigen woord weer te geven, maar wel heb ik de stijl van alle woorden en hun betekenis behouden. Waar het voor de lezer immers op aankomt is, dacht ik, dat ik hem van de woorden niet hetzelfde aantal, maar om zo te zeggen, hetzelfde gewicht bezorg. (Vertaling: R. Van den Broeck 2010: 13)

Cicero's 'non verbum pro verbo' zal het vertaaldiscours eeuwenlang beïnvloeden. Niet het weergeven ('reddere') van het aantal woorden, maar het behoud ('servavi') 
van de stijl ('genus') en de betekenis ('vim', dus veeleer uitdrukkingskracht) in 'woorden die bij ons idioom passen' zorgen voor 'hetzelfde gewicht'. Equivalentie wordt volgens Cicero niet bereikt door de woorden te tellen ('adnumerare'), maar door het gewicht van de woorden te wegen ('appendere'). Maar welke maat bij dat afwegen gehanteerd dient te worden, heeft de traditionele normatieve vertaaltheorie nooit weten te zeggen.

In het spoor van Cicero licht Hiëronymus, de vertaler van de Vulgaat, in een brief aan zijn vriend Pammachius (Litterae ad Pammachium de optimo genere interpretandi) uit het jaar 395 zijn manier van vertalen toe. Hij citeert Cicero, maar brengt tegelijk een belangrijk verschil aan:

Ik geef het immers niet alleen toe, maar kom er ook rond en openlijk voor uit: bij het vertalen van de Griekse teksten - met uitzondering van de Heilige Schrift, waar ook de volgorde der woorden een mysterie is - geef ik niet een woord met een woord, maar een gedachte met een gedachte weer (non verbum e verbo sed sensum exprimere de sensu). (Vertaling R. Van den Broeck 2010: 13, lichtjes gewijzigd)

Want, zo vervolgt hij:

Een woord-voor-woordvertaling verhult de betekenis, zoals welig tierend onkruid de gezaaide gewassen verstikt. (...) Om een dergelijk euvel te vermijden heb ik (...) mijn heilige Antonius zo vertaald dat, al vallen de bewoordingen anders uit, de gedachten geheel tot hun recht komen. Laat anderen op lettergrepen en letters jagen; let gij echter op de gedachten. (Vertaling R. Van den Broeck 2010: 14)

De dubbele onderscheiding tussen aan de ene kant de 'Heilige tekst' (die een letterlijk vertalen zou verlangen) en andere teksten, en aan de andere kant die tussen woorden en gedachten (of betekenissen) brengt Hieronymus in een ambivalente theoretische verhouding tot het vertalen, die bekend geworden is als de 'paradox van de vertaler'. Hij geeft mooi aan op welke wijze de equivalentie-eis de vertaler in zijn ban houdt: "Vertaal ik woord voor woord, dan klinkt het absurd; verander ik, noodgedwongen, ook maar iets in de constructie of de formulering, dan geef ik de indruk dat ik in mijn taak als vertaler tekortschiet" (vertaling R. Van den Broeck 2010: 14).

Vanaf de renaissance wordt een nieuw element aan de equivalentiegedachte toegevoegd: de vertaler als imitator van de kunstenaar. Een vertaler maakt niet zomaar een kopie van een werk, hij treedt in de voetsporen van de kunstenaar en 
imiteert in zijn eigen taal de schrijfhouding van de auteur. Dat die imitatie tegelijk een transformatie inhoudt wordt niet als nadeel, maar als bewijs van eigen kunstenaarschap gezien. Equivalentie krijgt de vorm van een geslaagde imitatie. Vanaf dan ontwikkelen zich eigen nationale vertaalstijlen, het meest uitgesproken in Frankrijk, waar onder invloed van theoretici als Etienne Dolet (1546: La manière de bien traduire d'une langue en aultre) en Joachim du Bellay (1549: Deffence et illustration de la langue françoyse) de gedachte van vertaling als imitatie tot in het extreem doorgetrokken wordt. Een vertaling is een vrije imitatie die volledig schatplichtig is aan de stijl en de eigenschappen van de doeltaal. De vertalingen die op grond van deze vertaalstijl tot stand kwamen zijn bekend geworden als 'les belles infidèles': vertalingen waren ofwel mooi en ontrouw of trouw en lelijk. Dat zulke vertalingen in belangrijke mate afweken van het origineel betekent echter niet dat ze de idee van equivalentie opgegeven hadden, integendeel, er werd een nieuw aspect aan de idee van equivalentie toegevoegd: de gelijkheid van effect. Vertalingen moesten op hun doelpubliek hetzelfde effect uitoefenen, dezelfde betekenissen teweegbrengen als het origineel. De Wirkungsgleichheit is ook vandaag nog een vaak gehoorde stelregel. Sinds de renaissance wordt aangenomen dat equivalentie wordt gerealiseerd wanneer een vertaler erin slaagt dezelfde taal te hanteren die de auteur gesproken zou hebben als hij in de tijd van de vertaler geleefd zou hebben en de doeltaal gesproken zou hebben. De opvatting dat een vertaling als een origineel in de eigen taal te lezen moet zijn is een variant daarvan.

Het is pas rond 1800 bij enkele theoretici van de Duitse romantiek dat er een sterke correctie op de renaissancistische en vroegmoderne aannames omtrent vertaalequivalentie doorgevoerd wordt. In 1813 zal Friedrich Schleiermacher in zijn invloedrijke lezing Über die verschiedenen Methoden des Übersetzens een belangrijke stap zetten om het vertalen aan de dominante, op identiteit gebaseerde equivalentienorm te onttrekken. Uitgaande van de taalrelativistische aanname dat talen bepalend zijn voor het denken en de waarneming van de wereld, zal Schleiermacher poneren dat de vreemdheid van de talen nooit volledig overwonnen kan worden:

Als het erop aankomt dat zijn lezers hem (de vertaler en zijn tekst, H.B.) begrijpen, dan moeten ze de geest van de taal opnemen die in de schrijver thuis was en ze moeten zijn individuele denkwijze en manier van waarnemen kunnen volgen. Om deze beide dingen te bewerkstelligen heeft de vertaler hen niets anders te bieden dan aan de ene kant hun eigen taal, die met de andere taal nergens echt overeenkomt, en aan de andere kant zichzelf in de manier waarop hij zijn auteur nu 
eens meer dan weer minder duidelijk herkend heeft, hem nu eens meer dan weer minder bewondert en goedkeurt. Lijkt vertalen, wanneer men het zo beschouwt, geen waanzinnige onderneming? (Schleiermacher 2004: 45-46)

Schleiermacher ziet voor het vertalen maar één oplossing: in een vertaling moet de vreemdheid van de andere taal en het unieke taalgebruik van de originele auteur door middel van een 'mit Kunst und Maß' toegepaste vreemdheid verschijnen. Schleiermacher introduceert een ander paradigma in het vertalen: het gaat niet meer om equivalentie of identiteit, maar om een vreemde gelijkenis (2004: 49). Met dat oxymoron installeert Schleiermacher het principe van de differentie in de vertaling: een vertaling kan niet anders dan verschillen van het origineel. Dit is de eerste ernstige kritiek op de equivalentienorm: het principe van de identiteit wordt vervangen door dat van de alteriteit. Schleiermachers denken over vertalen zal in de twintigste eeuw door invloedrijke vertalers en theoretici weer opgenomen worden, onder anderen door Walter Benjamin, Ortega y Gasset, Antoine Berman en Lawrence Venuti. De zogenaamde 'ethical turn' in de vertaalwetenschap beroept zich eveneens op hem.

\section{Equivalentie in het vertaalonderzoek}

Het begin van de begripsgeschiedenis van de term 'equivalentie' is, zoals gezegd, te situeren in het linguïstisch vertaalonderzoek van de jaren 50 en 60 van de vorige eeuw. Auteurs als R. Jakobson (1959), G. Mounin (1963) en J. C. Catford (1965) benaderden het vertalen als een puur linguïstisch fenomeen: het ging om het vervangen van taalmateriaal door ander taalmateriaal. Daarbij stelde zich uiteraard de vraag naar de mogelijkheid van linguïstische equivalentie tout court: kan er identiteit bestaan tussen talig verschillende items?

In "On Linguistic Aspects of Translation" (1959) brengt Roman Jakobson het linguïstisch uitgangspunt zo onder woorden: "Bij vertaling is dus sprake van twee equivalente boodschappen in twee verschillende codes. Equivalentie in verschil is het kernprobleem van de taal en de zaak waar het in de linguïstiek om draait" (2004: 130). Dat uitgangspunt gaf aanleiding tot het ontstaan van allerlei tweetalige lijsten met zogenaamde equivalente of liever 'corresponderende' paren op woordof collocatieniveau. De Stylistique comparée du français et de l'anglais. Méthode de traduction (1958) van Vinay en Darbelnet is daar een goed voorbeeld van. Jakobson 
geeft toe dat "op het niveau van de interlinguale vertaling doorgaans geen volledige equivalentie bestaat" (2004: 130), maar niettemin kan er dankzij de metalinguale functie van de taal - we kunnen altijd over de taal en dus ook over het verschil tussen twee verschillende items spreken - toch een hoge mate van equivalentie bereikt worden, tenminste wat het cognitieve gehalte van taaluitingen betreft: "Alle cognitieve ervaring en de classificatie ervan zijn over te brengen in iedere willekeurige bestaande taal" (2004: 131). Zelfs als de ene taal niet over de grammaticale of lexicale middelen van een andere taal beschikt, kunnen inhouden equivalent weergegeven worden. Jakobson geeft verschillende voorbeelden daarvan. Maar hij maakt één belangrijke uitzondering: teksten met een dominante poëtische functie - teksten die de aandacht vestigen op hun eigen talige karakter, op hun materialiteit, m.a.w. poëzie - zijn onvertaalbaar. Alleen 'creatieve transpositie' (2004: 134) houdt hij voor mogelijk. De vraag is of hij die uitspraak ook laat gelden voor de vertaling van literair proza: ook al zal de poëtische functie in prozateksten minder intens zijn, ze blijft wel bepalend. Een literaire vertaling kan bovendien niet volstaan met de vertaling van het cognitieve gehalte van de zinnen. Jakobsons voorbeeld is sprekend: het Italiaanse 'traduttore, traditore' is onvertaalbaar omdat het paronomastische taalspel ( $\operatorname{tr}-\operatorname{tr}, \mathrm{du}-\mathrm{di}$, ore - ore), dat aan de uitdrukking haar kracht geeft, in vertaling verdwijnt. Een omschrijvende vertaling van de cognitieve inhoud: 'de vertaler is een verrader' is eigenlijk niet meer equivalent te noemen. Het belangrijkste kenmerk - de literariteit - blijft onvertaald.

Een andere belangwekkende bijdrage tot de linguïstische vertaaltheorie was het beknopte, maar nog altijd erg interessante werkje van J.C. Catford A Linguistic Theory of Translation uit 1965. Catford geeft aan equivalentie een centrale plaats in de definitie van vertalen: "Translation may be defined as follows: the replacement of textual material in one language (SL) by equivalent textual material in another language (TL)" (1965: 20, cursivering van de auteur). Catford maakt een onderscheid tussen total translation, die equivalentie op alle niveaus (i.c. grammaticaal en lexicaal) realiseert en restricted translation, die equivalentie op slechts één niveau realiseert. Catford geeft een interessant voorbeeld dat illustreert dat hij als linguïst vooral geïnteresseerd is in de mogelijkheid van equivalentie. De Engelse uitdrukking 'it's raining cats and dogs' kan volgens hem op drie manieren equivalent vertaald worden:

- Het is regenend katten en honden (woord-voor-woord-vertaling)

- Het regent katten en honden (letterlijke vertaling)

- Het regent pijpenstelen / Het regent oude wijven (vrije vertaling) 
Vervolgens maakt Catford een beweging die de hele discussie omtrent equivalentie tot op de dag van vandaag problematisch maakt: de vaststelling of twee taaluitingen equivalent zijn wordt afhankelijk gemaakt van de beoordeling ervan door menselijke subjecten. Hij schrijft:

A textual translation equivalent (...) is any TL form (text or portion of text) which is observed to be the equivalent of a given SL form (text or portion of text). The discovery of textual equivalents is based on the authority of a competent bilingual informant or translator. (1965: 27)

Equivalentie wordt dus in de handen gegeven van subjecten, terwijl de sterkte van de linguïstische benadering juist lag in de mogelijkheid van een objectieve benadering van verschillen en overeenkomsten tussen talen.

Catford introduceert daarnaast nog een ander interessant element. Omdat de betekenis van twee termen uit verschillende talen nagenoeg nooit dezelfde is, komt het in de vertaling van teksten of tekstelementen aan op hun 'uitwisselbaarheid in een gegeven situatie': "SL and TL texts or items are translation equivalents when they are interchangeable in a given situation" (1965: 49). Hij gaat verder:

The TL text must be relatable to at least some of the situational features to which the SL text is relatable. Presumably, the greater the number of situational features common to the contextual meanings of both SL and TL text, the 'better' the translation. The aim in total translation must therefore be to select TL equivalents not with "the same meaning" as the SL items, but with the greatest possible overlap of situational range. (1965:49)

Deze passage anticipeert op de latere functionele en communicatieve benadering van vertalen: een uiting is equivalent wanneer ze in dezelfde situatie functioneert.

Een derde belangrijke bijdrage tot de equivalentie-discussie, zeker voor literair vertalen, is die van Eugene Nida. Hij is de eerste die linguïstische inzichten op een normatieve manier in het praktische vertalen binnenbrengt, wat de zaak vanuit onderzoeksstandpunt uiteraard problematiseert. Nida was een Bijbelvertaler met evangeliserende intenties en stoorde zich aan de formeel-corresponderende manieren van vertalen van de Bijbelteksten - een erfenis sinds Hiëronymus - die de teksten onverstaanbaar maakten. Die formele correspondentie wilde hij vervangen door een dynamische equivalentie. Overeenkomsten op lexicaal en grammaticaal vlak 
moesten plaatsmaken voor equivalenten die nauwer aansloten bij het 'natuurlijke' taalgebruik van de doelcultuur. Nida doet een beroep op het renaissancistische vertaalprincipe dat een vertaling bij haar lezers dezelfde reacties moet teweegbrengen als het origineel bij zijn lezers. Om dat te bereiken moet een vertaler streven naar de 'closest natural equivalent of the source-language message' (Nida 1964: 166). Om die boodschap te achterhalen greep Nida terug naar de transformationeel-generatieve grammatica van Chomsky: hij herleidde de essentiële betekenis tot zogenaamde kernzinnen - Chomsky's dieptestructuren - en transformeerde die vervolgens in natuurlijk klinkende doeltaalzinnen.

Uiteraard zijn hier veel vragen bij te stellen: hoe stel je vast hoe het doelpubliek van het origineel reageerde? Wie bepaalt wat een 'natuurlijk' equivalent in de doeltaal is? Welke overwegingen spelen er in de transfer van dieptestructuren naar oppervlaktestructuren?

Met de zogenaamde 'descriptive turn' in de vertaalwetenschap, en versterkt nog in de 'cultural turn', veranderde ook de benadering van het begrip 'equivalentie'. Omdat aan het begrip toch een geur van normativiteit kleefde en omdat de verschillende linguïstische benaderingen, ondanks alle verzekeringen dat equivalentie nooit volledig mogelijk is en altijd slechts gradueel gerealiseerd kan worden, de verdenking niet van zich konden afschudden dat equivalentie stoelt op de aanname dat er zoiets zou bestaan als talige invariantie die aan geen enkele historische verandering onderhevig is, ontstond vooral in de zogenaamde functionele vertaalbenadering de wens om komaf te maken met het begrip 'equivalentie' tout court (het duidelijkst bij Snell-Hornby 1988). Voor de functionele vertaalbenadering was equivalentie alleen maar een hinderlijke term, hinderlijk bij het vertalen zelf en ongeschikt om het te beschrijven. Dat is begrijpelijk, want in het functionalisme worden bron- en doelteksten volledig ondergeschikt gemaakt aan de bedoelingen die de menselijke subjecten (opdrachtgevers, vertalers) ermee hebben. Omdat dat voor literatuur niet opgaat, lijkt functionele equivalentie (en varianten zoals tekstuele equivalentie en communicatieve equivalentie) voor het literair vertaalonderzoek ongeschikt.

De descriptieve vertaalwetenschap kan het begrip 'equivalentie' alleen al hierom niet eenvoudig overboord zetten omdat het, zoals gezegd, een begrip blijft dat door vertalers impliciet of expliciet gebruikt wordt. Als vertalers van een vertaling equivalentie met de brontekst eisen, dan is equivalentie een legitiem onderzoeksobject van de vertaalwetenschap. Een van de grondleggers van de descriptieve vertaalwetenschap, Gideon Toury, neemt daarom een veel genuanceerder standpunt in. Volgens hem zijn het de telkens wisselende normen die bepalen wat equivalentie is 
en wat niet. Er bestaat niet zoiets als een aan alle historie onttrokken invariant. Toury herdefinieert 'equivalentie' op een manier die het begrip redt van de uitschakeling en tegelijk hanteerbaar maakt voor het vertaalonderzoek:

In plaats van een ahistorisch, voornamelijk prescriptief begrip, moet het een historisch begrip worden. In plaats van naar één enkele relatie, die een telkens terugkerend type invariant aanduidt, moet het verwijzen naar elke mogelijke relatie die men karakteristiek heeft geacht voor vertaling onder een gespecificeerde reeks omstandigheden. (Toury, 2004/1995: 169)

Vertaalonderzoek is bij Toury onderzoek naar de normen die het vertalen sturen. Ook daar kan men zich natuurlijk vragen bij stellen: normenonderzoek mondt in de regel uit in de beschrijving van de omstandigheden waarin vertalingen plaatsvinden en van de instanties die het vertalen beïnvloeden (vertaalpolitiek, uitgeversbeleid, culturele factoren, literaire bewegingen ...). Maar ook dat kan voor vertalers uiteraard nuttige informatie zijn.

\section{Op het snijpunt tussen norm en begrip}

In de geschiedenis van het vertalen heeft de spanning die inherent is aan de equivalentienorm - een vertaling moet equivalent zijn, maar equivalentie is nooit (volledig) mogelijk - tot pogingen geleid om hem zo al niet af te schaffen dan toch uit het centrum van het spreken over vertalen te verwijderen. Omdat equivalentie echter zo nauw verbonden is met het identiteitsdenken zal een steekhoudende kritiek op equivalentie zich op andere dan de gebruikelijke aannames moeten baseren. Schleiermacher was wellicht de eerste om te eisen dat een vertaling niet zozeer aandacht moet hebben voor 'hetzelfde nog een keer' als veeleer voor de niet te overwinnen alteriteit van bron- en doeltaal. Hij probeerde in het vertalen ruimte te scheppen voor die alteriteit. Maar ook hij bleef gevangen in de dualistische aannames van het identiteitsdenken (brontaal - doeltaal, hetzelfde - het andere, het vreemde - het eigene enz.).

De meest radicale ondergraving van het equivalentieprincipe is te vinden in Walter Benjamins De opgave van de vertaler (1923). Voor Benjamin kan de opgave van een vertaling er niet langer in bestaan "hetzelfde' herhaald" (Benjamin 2004/1923: 59) te zeggen. Vertaling staat niet in dienst van de lezer die het origineel niet verstaat, 
veeleer hebben vertalingen de vinger aan de pols van de historische taalbeweging, die voor betekenisveranderingen in de taal en voor veranderende tendensen in de literaire werken zorgt. Die taalbeweging is volkomen autonoom en onttrekt zich aan de invloed van menselijke subjecten (schrijvers, vertalers, uitgevers, opdrachtgevers ...). De opgave van de vertaler bestaat erin getuigenis van die taalbeweging af te leggen. Daarom kan een vertaling niet langer bestaan in de 'nauwkeurige weergave' van een origineel, want eigenlijk kan niemand zeggen, zo Benjamin, wat een nauwkeurige weergave eigenlijk is: niemand kan de maat ervan aangeven. Daarom kan de equivalente betekenisweergave niet langer de norm voor een geslaagde vertaling zijn (Benjamin 2004/1923: 64). In het spoor van Schleiermacher en Benjamin hebben zich in de twintigste eeuw heel wat vertaaltheorieën ontwikkeld die kritisch staan tegenover vertaling als equivalente weergave van een origineel.

Deze kritiek onderscheidt zich van de kritiek die van functionalistische benaderingen uitgaat, die het vertalen in de handen geven van die andere hoeksteen van het identiteitsdenken: het beschikkende menselijke subject. In de 'ethical turn' (met vertalers als Antoine Berman en Lawrence Venuti) krijgt de vreemdheid van de andere tekst meer aandacht en wordt equivalentie als norm naar de rand verdrongen. In feministische vertaaltheorieën worden 'ingrepen' toegestaan in naam van de subversie van eeuwenoude genderpatronen; in postkoloniale vertaaltheorieën gebeurt hetzelfde in naam van de subversie van vanzelfsprekend geachte culturele hiërarchieën en patronen. De geldigheid van equivalentie als norm staat in de hedendaagse vertaalprakrijk en in het vertaalonderzoek zwaar onder druk. In hoeverre die nieuwe benaderingen aan de equivalentie ontsnappen en een vertaling buiten de equivalentie om mogelijk maken, zal moeten blijken.

\section{Bibliografie}

Benjamin, Walter. “De opgave van de vertaler.” In Naaijkens, Ton, Cees Koster, Henri Bloemen en Caroline Meijer (red.), 2004/1923, p. 59-67.

Berman, Antoine. La traduction et la lettre ou l'auberge du lointain. Paris: Seuil, 1985.

Catford, J.C. A Linguistic Theory of Translation. Oxford: Oxford University Press, 1965.

Hermans, Theo. "Vertalen als navelstaren.” In Filter. Tijdschrift over vertalen 11:2 (2004), p. 3-18.

Jakobson, Roman. "On the Linguistic Aspects of Translation." In Reuben Brower (ed.), On Translation.

Cambridge, Mass.: Harvard University Press, 1959, p. 232-239.

Jakobson, Roman. "Enkele linguïstische aspecten van het vertalen.” In Naaijkens, Ton, Cees Koster, Henri Bloemen en Caroline Meijer (red.), 2004/1959, p. 129-134. 
Kenny, Dorothy. “Equivalence.” In Baker, Mona (red.). Routledge Encyclopedia of Translation Studies. London/New York: Routledge. 2009, p. 96-99.

Leal, Alice. "Equivalence." In Gambier, Yves and Luc Van Doorslaer (red.). Handbook of Translation Studies. Vol. 3. Amsterdam/Philadelphia: John Benjamins, 2012, p. 39-46.

Mounin, Georges. Les problèmes théoriques de la traduction. Paris: Gallimard, 1963.

Munday, Jeremy. Introducing Translation Studies. Theories and Applications. London/New York: Routledge, 2008.

Naaijkens Ton, Cees Koster, Henri Bloemen en Caroline Meijer (red.). Denken over vertalen. Tekstboek vertaalwetenschap. Nijmegen: Van Tilt, 2004.

Neubert, Albrecht. “Equivalence in Translation.” In Kittel, Harald, Armin Paul Frank, Norbert Greiner et. al. (red.). Übersetzung - Translation - Traduction. Ein internationales Handbuch zur Übersetzungsforschung / An International Encyclopedia of Translation Studies / Encyclopédie internationale de la recherche sur la traduction. Berlin: De Gruyter. 1. Teilband, 2008, p. 329-342.

Newmark, Peter. Approaches to Translation. Oxford: Pergamon, 1981.

Nida, Eugene. Towards a Science of Translating. With Special Reference to Principles and Procedures involved in Bible Translating. Leiden: Brill 1964.

Sánchez, María T. The Problems of Literary Translation. A Study of the Theory and Practice of Translation from English into Spanish. Oxford: Lang, 2008.

Schleiermacher, Friedrich. "Over de verschillende methoden van het vertalen." In Naaijkens, Ton, Cees Koster, Henri Bloemen en Caroline Meijer (red.), 2004/1813, p. 41-53.

Simms, Karl (red.). Translating Sensitive Texts: Linguistic Aspects. Amsterdam/Atlanta: Rodopi, 1997. Snell-Hornby, Mary. Translation Studies. An Integrated Approach. Amsterdam/Philadelphia: Benjamins, 1998.

Toury, Gideon. "De aard en de rol van normen in vertaling." In Naaijkens, Ton, Cees Koster, Henri Bloemen en Caroline Meijer (red.), 2004/1995, p. 163-173.

Van den Broeck, Raymond. De vertaling als evidentie en paradox. Antwerpen: Fantom, 1999.

Venuti, Lawrence. The Scandals of Translation. Towards an Ethics of Difference. London/New York: Routledge, 1998.

Vinay, Jean-Paul en Jean Darbelnet. Stylistique comparée du français et de l'anglais. Paris: Didier, 1958. 


\title{
2.2. \\ Verre culturen en het vertalen van realia
}

\author{
Luk Van Haute
}

Een en ander maakt vertalen uit talen van verre landen (het Japans in mijn geval) net dat tikje anders dan uit die van onze buurlanden. Niet alleen de linguïstische en geografische afstand is groter, ook cultureel zijn er aanzienlijke verschillen. Verschijnselen en begrippen die specifiek zijn voor een bepaalde cultuur, en de woorden of termen die ernaar verwijzen, noemen we in de vertaalwetenschap "realia" (Grit 1997: 42). En hoewel we tegenwoordig (bijna) allemaal sushi eten, blijft bij veel van die realia het Verre Oosten echt nog wel 'ver'.

Voor de vertaler is de centrale vraag hierbij: hoeveel voorkennis mag je van je lezerspubliek verwachten? Wat kennis van pakweg de Franse cultuur betreft, is de gemene deler ongetwijfeld groter dan bij verre culturen. Een literaire vertaling maak je in principe niet uitsluitend voor kenners van die cultuur. Je moet ook rekening houden met de leken. Het is dus voortdurend afwegen wat je als '(min of meer) algemeen geweten' mag beschouwen. Culinaire termen zijn hierbij een voor de hand liggend voorbeeld. Sushi kent iedereen, dus daar is de keus niet moeilijk. Maar wat met yakitori of edamame? Die lekkernijen zijn bekend bij wie weleens een Japans restaurant bezoekt, maar dat geldt zeker niet voor alle lezers. Er zijn ook historische evoluties in deze problematiek, door onder meer de invloed van het internet en de groeiende globale verspreiding van populaire cultuurvormen als manga (strips) en anime (animatiefilms).

Diederik Grit zet in zijn artikel "De vertaling van realia” acht mogelijke strategieën op een rij: handhaving, leenvertaling, benadering, omschrijving of definiëring, kernvertaling, adaptatie, weglating, en een combinatie van deze. Ik voeg er ook nog 'voetnoten' en 'verklarende woordenlijst' aan toe. Geen van deze strategieën is alleenzaligmakend en overal toepasbaar. Het is bij ieder apart geval weer wikken en wegen wat het beste is. Grit geeft voorbeelden uit het Nederlands, maar laten we even kijken naar het Japans. 
Een algemene regel bij veel uitgeverijen is dat je een woord mag laten staan (handhaving dus) als het in Van Dale is opgenomen. Het hoeft in dat geval ook niet cursief. Toch is die aanpak niet altijd evident. De afgelopen jaren zijn Japanse woorden in Van Dale beland als 'karoshi' en 'hikikomori', maar aannemen dat de betekenis ervan ook algemeen bekend is, zou voorbarig zijn. Ga je dus voor 'hikikomori' (handhaving), 'sociale kluizenaar' (omschrijving), 'teruggetrokkene' (leenvertaling) of nog een andere strategie? Een bijkomend probleem bij handhaving is trouwens dat dezelfde Japanse klank in het Nederlands bij relatief recent opgenomen woorden (zoals 'futon' of 'no') soms anders wordt gespeld dan bij oudere (zoals 'samoerai' of 'butoh'). Volg je Van Dale of blijf je consequent binnen je eigen tekst?

Een argument pro handhaving is dan weer dat het in deze tijden van Google en Wikipedia voor lezers vrij eenvoudig is om een woord op te zoeken als ze het niet kennen. Maar overdreven handhaving zou de redactie (en het niet-deskundige lezerspubliek) tot wanhoop drijven. Dus geen zinnen als: 'Ik kocht aan de midori no madoguchi naast de kaisatsuguchi een teiki voor de shinkansen.'

Zo kan elk van de strategieën werken in het ene geval en problematisch zijn in een ander. De 'honderdyenshop' kan als leenvertaling van 'hyakuenshoppu' werken, als lezers tenminste weten dat honderd yen ongeveer een euro (weinig geld dus) is. Bij 'nieuwe stamlijn' (shinkansen) kunnen ze zich waarschijnlijk niet veel voorstellen.

Benadering kan verdedigbaar zijn bij 'hst' voor 'shinkansen' of bij 'IC-trein' voor 'kyūkō', maar bij 'klompen' of 'slippers' voor 'geta' of 'kippenspiesjes' voor 'yakitori' loop je toch het gevaar een verkeerde indruk te wekken. In Nederland doemt bij dat laatste pindasaus op, kan ik me voorstellen.

Omschrijving of definiëring werd vroeger vaker toegepast, heb ik de indruk. Het kan handig zijn, zeker in combinatie met handhaving. Je behoudt bijvoorbeeld het woord bij de eerste vermelding ('Ik bestelde yakisoba'), om het dan in de volgende zin te omschrijven: ('De serveerster zette het bord gebakken noedels voor me neer.'). Maar het is niet altijd even doeltreffend. Is 'gefermenteerde sojabonen' bijvoorbeeld zo veel duidelijker dan 'natto'?

Het mag ook niet te opzichtig of onnatuurlijk overkomen: 'manga, de typische Japanse strip'. Bij uitbreiding geldt dit ook voor persoons- en plaatsnamen (die ik ook onder de ruime paraplu van realia stop). Een Japanner weet automatisch wie of wat wordt bedoeld, of maakt een specifieke associatie, een buitenlander niet noodzakelijk. Zo kan 'Isuzu Yamada' in de vertaling ter verduidelijking 'de actrice Isuzu Yamada’ worden. Maar hier is voorzichtigheid geboden. Tenslotte voeg je aan 
de brontekst extra tekst toe, in wezen een soort verwerkte voetnoot. Je lezer kan ook gaan denken: waarom doet deze auteur zo uitleggerig?

In de Engelse vertaling van Takashi Hiraide's De kat trof ik een paar van die extreme voorbeelden aan in verband met plaatsnamen. In mijn vertaling staat: "Net toen we het thuis niet langer uithielden, werd ik toevallig gebeld door een vriend die in een bar in Shinjuku zat te drinken" (2015: 92). Dat is in het Engels: "Right at the point where it had become unbearable a friend called up from a bar in $\underline{S h i n j u k u}$, one of the major entertainment districts in the city, its narrow labyrinthine alleys lined with numerous little drinking spots" (2014: 75-76). Belangrijke afweging hier is ook: is de extra uitleg nodig voor het (contextuele) begrip van de tekst, of is het alleen een leuk weetje?

Ook kernvertaling werd vroeger veel gebruikt, maar vaak uit gemakzucht. Een ' $k \bar{u} k a n$ junkyō' (op de Engelstalige infoborden in Tokio een 'section semi-express' genoemd), wordt dan gewoonweg een 'trein'. En een 'yukata' is eenvoudig een 'kimono'. Probleem hiermee is dat je kunt raken aan de stijlkenmerken van een auteur. Voor iemand als Haruki Murakami zijn specifieke merknamen en dergelijke juist een belangrijk stilistisch element. Zijn personages rijden niet met 'de auto' of drinken niet zomaar 'een glas whisky'. Zo ook was Jun' ichiro Tanizaki heel precies in zijn beschrijvingen van kleding. Het verdient aanbeveling dat te respecteren.

Nog minder wenselijk is adaptatie. Personages drinken dan geen Kirin maar Jupiler of Heineken (kernvertaling zou zijn: 'een biertje'). De redenering daarachter is exotiek vermijden en de leeservaring even 'natuurlijk' maken als voor de lezer van de brontekst. Een frappant voorbeeld van hoe zoiets fout kan lopen, vond ik in de Engelse vertaling van het kortverhaal 'Downtown' van Fumiko Hayashi uit 1948. In zijn vertaling van 1956 verandert Ivan Morris zalm in kabeljauw, omdat hij die vis beter vindt passen bij arme mensen (zalm was midden jaren vijftig in het Westen dure vis, in tegenstelling tot in Tokio vlak na de oorlog). Helaas is de prijs van beide vissen inmiddels weer in omgekeerde richting gefluctueerd. Met dat soort ingrepen kun je dus maar beter uitkijken.

En dan rest ons nog weglating. Je zou geneigd zijn te denken dat deze strategie laakbaar is en respectloos tegenover de auteur van de brontekst, maar ze wordt, vooral in de VS, toch nog verbazend vaak toegepast, heb ik mogen vaststellen. En in bepaalde gevallen gaat het om wat Will Slocombe 'ethisch vertalen' noemt (2004: 2).

In 2008 vertaalde ik Murakami's roman Dans dans dans. Toen ik de brontekst vergeleek met de Engelse vertaling, viel me meteen een verschil in dikte op. Ik merkte gaandeweg dan ook dat er nogal wat tekst was verdwenen, zowat een vierde 
van het boek zelfs. Een opmerkelijk voorbeeld was deze passage (een dertiger, een typische Murakami-protagonist, zit met een meisje van dertien in de bar van een hotel op Hawaii):

Ik dronk opnieuw een pina colada en zij nam een vruchtensap. "Mag ik daar nog een slokje van?" zei Yuki, naar mijn pina colada wijzend. "Ja hoor," zei ik, en ik verwisselde onze glazen. Met een rietje slurpte Yuki een tweetal centimeter pina colada naar binnen. "Lekker," zei ze. "Het smaakt een beetje anders dan in de bar van gisteren."

Ik riep de ober en bestelde nog een pina colada. Die gaf ik helemaal aan Yuki. "Drink maar op," zei ik. "Als je me elke avond gezelschap houdt, kun je binnen een week de beste pina colada-kenner van alle Japanse scholieren worden."

Bij het zwembad speelde een heus dansorkest "Frenesi". (2008: 302)

In de Engelse vertaling staat:

I had a pina colada again and Yuki her usual fruit punch. A dance band was playing "Frenesi". (1994: 256)

Naast drank voor minderjarigen is om 'ethische' redenen ook een Playboy en nogal wat seks, drugs en rock-'n-roll verdwenen, en dat voor een boek dat Dans dans dans heet.

Het is geen alleenstaand geval. In het verhaal 'Gifkruid' van Ranpo Edogawa uit 1927 staat: "Bovendien had ze alweer een vijf maanden oude foetus in haar buik"(2014: 115). De vrouw drijft die vrucht af door een speciaal kruid te eten. In het Engels wordt dat iets vager: "Her stomach was swollen with yet another on the way" (1962: 37). Abortus ligt gevoelig in Amerika, en al helemaal bij een foetus van vijf maanden.

Tussen haakjes: je krijgt daardoor weleens vervelende opmerkingen van de persklaarmaker, die zich baseert op de Engelse vertaling en discrepanties met de Nederlandse ziet. En Engelse vertalingen als tussenvertaling gebruiken (wat helaas nog weleens gebeurt) is ook om die reden al helemaal geen goed idee.

Het is me echter ook al overkomen, bijvoorbeeld bij romans van een eeuw of meer oud, dat het aantal realia zo groot is, dat ik opteer voor het achteraan toevoegen van een verklarende woordenlijst (met daarin de in cursief gehandhaafde woorden). Het voordeel ten opzichte van voetnoten is dat zo'n lijst minder storend werkt. Wie het begrip of de term begrijpt, kan gewoon doorlezen. 
In het Japans heb je verder ook het verschijnsel dat er Engelse woorden worden 'uitgevonden'. Op het eerste gezicht lijken het dus leenwoorden, maar eigenlijk zijn het neologismen. ${ }^{1}$ Een bekend voorbeeld is 'walkman'. Dat woord bestond niet in het Engels. Toen Sony zijn draagbare cassettespeler op de markt bracht, gaf het bedrijf hem die naam mee. De walkman veroverde de wereld en zo kwam het woord ook het Engels en het Nederlands binnen, zodat het voor vertalers geen probleem meer vormt. Maar dat ligt anders bij bijvoorbeeld 'konbini', de afkorting van het Engelse 'convenience store'. Deze winkels zijn in het Japanse straatbeeld zo alomtegenwoordig en maken zo'n centraal deel uit van het dagelijks leven dat niemand nog stilstaat bij de etymologie van het woord 'konbini'. Bij ons zijn mogelijke vertalingen/equivalenten als 'gemakswinkel', 'nachtwinkel' of 'buurtsuper' echter lang niet zo ingeburgerd en/of ze dekken niet helemaal de lading.

Bij talen als het Chinees, Japans, Koreaans, Arabisch, Russisch en Thais is er bovendien een ander schriftsysteem. Dit heeft op zich niet direct met realia te maken, maar het kan wel voor extra complicatie zorgen. Het Japanse schrift combineert 'karakters' of 'kanji' (bijna tweeduizend jaar geleden 'geleend' van de Chinezen) met twee fonetische systemen op basis van syllaben: hiragana en katakana.

Een voorbeeld van het complexe spel met die systemen trof ik aan in de openingszinnen van de roman Sensei no kaban (2001) van Hiromi Kawakami, die als Nederlandse titel De tas van de leraar heeft. Zowel over 'kaban' (tas) als 'sensei' (leraar) was enige discussie met de uitgever (over een titel heeft een vertaler nu eenmaal doorgaans niet het laatste woord). Het woord 'sensei' zorgde ook elders voor problemen. Dit zijn de twee openingszinnen (mijn onderlijning):

$$
\begin{aligned}
& \text { 正式には松本春綱先生であるが、センセイ、とわたしは呼ぶ。「先生」でもな } \\
& \text { く、「せんせい」でもなくカタカナで「センセイ」だ。 }
\end{aligned}
$$

Aan het woord is een vrouw van middelbare leeftijd, die in een kroeg haar oud-leraar van op de middelbare school tegen het lijf loopt. Omgezet naar ons alfabet wordt dit:

Seishiki ni wa Matsumoto Harutsuna-sensei dearu ga, sensei, to watashi wa yobu.

'Sensei' de mo naku, 'sensei' de mo naku, katakana de 'sensei' da.

1 Zie ook 2.4. 
Wat meteen opvalt: de onderlijnde woorden in het Japanse schrift zien er telkens duidelijk anders uit, maar in het alfabet staat drie keer hetzelfde: 'sensei'. Het eerste is kanji, het schrift dat normaal wordt gebruikt voor dit woord. Het tweede is hiragana, het schrift voor voornamelijk partikels, voorzetsels, uitgangen en dergelijke. Dit zou echter ook nog een aanvaardbare manier zijn om het woord 'sensei' te schrijven. De derde versie is katakana, dat hiervoor normaal nooit zou worden gebruikt, want het dient in principe voor vreemde woorden, of voor onomatopeeën.

Letterlijk staat er: "Officieel is het Haratsuna Matsumoto-sensei, maar ik noem hem 'sensei'. Het is niet 'sensei', het is ook niet 'sensei', het is 'sensei' in katakana." Simpel dus, maar niet een vertaling die je naar een redacteur kunt sturen. Je moet er dus iets anders op vinden.

Wat is het in het Duits geworden?

Offiziell müsste ich meinen alten Lehrer bei seinem vollen Namen nennen: Harutsuna Matsumoto-sensei - Herr Lehrer Harutsuna Matsumoto -, aber für mich bleibt er einfah der «Sensei». (Ursula Gräfe \& Kimiko Nakayama-Ziegler, 2008: 5)

We zien hier definiëring/omschrijving van het woord 'sensei', en ook wat contextuele toevoeging. De drie schriftvariaties (en daarmee in feite de hele tweede zin) worden weggelaten.

Het Frans:

En bonne et due forme, c'est le professeur Matsumoto Harutsuna, mais je l'appelle seulement «le maître $»$. Et encore sans majuscule, le maître, tout simplement. (Elisabeth Suetsugu, 2005: 3)

Hier is sensei (geen handhaving) eerst 'professeur' dan 'maître' (met toevoeging van het lidwoord 'le'). En er staat: 'zonder hoofdletter'.

Het Engels:

His full name was $\underline{\mathrm{Mr}}$. Haratsuna Matsumoto, but I called him 'Sensei.' Not ' $\underline{\mathrm{Mr}}$,' or 'Sir,' just 'Sensei.' (Allison Markin Powell, 2012: 1)

In deze kortste en eenvoudigste vertaling hebben we eerst 'Mr.' en verder 'Sir' en 'Sensei'. Eigenlijk is dit een wat rare oplossing. Alsof in een vertaling van een Engelse roman zou staan: "Ik noemde hem niet 'meneer' of 'de heer' maar 'sir." 
Tot slot het Nederlands:

Officieel had ik hem bij zijn volledige naam en titel moeten aanspreken, met Harutsuna Matsumoto-sensei dus, maar ik noemde hem gewoonweg Sensei. Niet 'sensei', maar 'Sensei' met een hoofdletter. (Luk Van Haute, 2010: 3)

Hiermee behield ik de nuance dat het ongebruikelijk is, want 'sensei' is een zelfstandig naamwoord, dus normaal niet met een hoofdletter, maar hier wel, omdat het voor de vrouw fungeert als zijn (eigen)naam. Ook het spelen met het schriftsysteem blijft hierdoor (enigszins) bewaard. Het gaat niet alleen om het woord 'sensei' op zich, maar ook om de schrijfwijze.

Een lezer merkte trouwens per mail op: hoe kun je nu iemand 'noemen' met een hoofdletter? Maar dat is nu eenmaal de betekenis van het Japanse werkwoord ' $y o b u$ ', en je kunt iemand evenmin 'in katakana' noemen. Het is precies de bedoeling van de auteur dat het ongewoon klinkt.

Met het Japanse schrift wordt dus gespeeld. Boven minder frequent gebruikte kanji (of ernaast bij verticaal gedrukte teksten) wordt fonetisch de uitspraak geschreven (want ook Japanners kunnen tegenwoordig niet al die tekens zomaar lezen). Soms nemen ze echter de uitspraak van een ander kanji. Bijvoorbeeld 'nusumu' (stelen) boven 'toru' (pakken) in De kat. Welk van beide kies je dan? In een mail aan de uitgever stoorde een lezeres zich overigens aan 'jatten' (mijn keus), want volgens haar 'paste dat niet bij de Japanse cultuur'. Ze wilde, uit onwetendheid, ook al ethisch vertalen.

Ook met het visuele aspect van het schrift wordt gespeeld. 川 is het kanji voor 'rivier' (let op het middelste streepje, dat iets korter is). Dan lees je een zin als: 'De ouders en hun kind sliepen in de vorm van rivier.' Mogelijke vertaling is: 'Ze sliepen met het kind tussen hen in.' De betekenis klopt, maar het taalspelletje is weg. Tegenwoordig hebben zetters geen technische problemen meer met het Japanse schrift. Ik heb het karakter dus al overgenomen in de vertaling ('in de vorm van het kanji 川'). Maar bij collega Geert van Bremen zag ik een andere, ingenieuze oplossing: 'slapen in de jij-vorm' (Takuji Ichikawa 2011: 77). Ook hier speelt dus de keus in strategie: handhaving, leenvertaling, adaptatie ...?

Er zijn meer zulke dingen. 八 is het karakter voor 'acht' en wordt weleens gebruikt om aan te geven dat iemand zijn wenkbrauwen fronst. Je wenkbrauwen optrekken 'in de vorm van het cijfer acht' ligt enigszins moeilijk. Een mogelijkheid is 'tot omgekeerde v's'. Iets soortgelijks heb je met: 'zijn mond vertrekken in de vorm van 
(het fonetische teken) $\uparrow($ he)'. Het wil zeggen: een mondhoek optrekken. Hiervoor heb ik nog geen pasklare 'taaloplossing' gevonden of gezien.

Nog een bijzonder geval: in Japan gebruiken ze tegenwoordig onze jaarrekening, maar ze hebben ook een eigen systeem, dat werkt met regeerperiodes van de keizers. Zo is 2018 in Japan ook het jaar Heisei 30, omdat keizer Akihito in 1989 de troon besteeg en zijn regeerperiode de naam Heisei kreeg. Maar laat je dat staan of pas je het aan? De voor de hand liggende keus hier is omzetten naar onze tijdrekening, omdat de lezer anders niet begrijpt over welk jaar het gaat. Maar ik heb er ook al voor gekozen om het Japanse systeem te behouden in vertaling. Met name in het verhaal 'Kroniek van de overtocht naar Fudaraku' van Yasushi Inoue (1961). Dat verhaal speelt zich af in de zestiende eeuw, wat ook uit de context duidelijk wordt. Ik heb hier de Japanse jaartelling behouden, omdat het bij de gemiddelde hedendaagse Japanse lezer evenmin parate kennis is dat 'het achtste jaar van Eiroku' overeenkomt met 1565. In dit concrete geval achtte ik het precieze jaar minder belangrijk dan het historische trekje.

Ook leeftijden werden traditioneel anders geteld. In het systeem van kazoedoshi ben je een jaar oud bij de geboorte en word je twee op 1 januari. Een baby van een paar maanden oud kan dus al 'twee jaar' zijn. Een interessant dilemma had ik bij de vertaling van Yasunari Kawabata's roman Schoonheid en verdriet (1965), waarin een vrouw van veertig en een meisje van zeventien (dat een relatie heeft met een oudere man) voorkomen, maar dan wel in kazoedoshi. Eigenlijk waren ze volgens onze telling dus negenendertig en zestien respectievelijk. Ik heb toch de kazoedoshi behouden, omdat de leeftijd van 'veertig' ook symbolisch belang heeft, en een seksuele relatie van een oudere man met een meisje van zestien toch nog net iets anders is dan met een van zeventien volgens onze eigentijdse moraal (de enige keer dat ik 'ethisch vertalen' in overweging nam).

Zoals ze zo mooi zeggen in het Japans: keesu bai keesu. 


\section{Bibliografie}

Edogawa, Ranpo. “Gifkruid.” (1927). Vert. Luk Van Haute in Liefdesdood in Kamara (2014), p. 114-118. / Vert. Seth Jacobowitz in The Edogawa Rampo Reader. Kurodahan Press, 2008, p. 35-41.

Grit Diederik, "De vertaling van realia." Filter 4:4 (1997), p. 42-48. Geactualiseerde versie in Naaijkens, Ton, Cees Koster, Henri Bloemen en Caroline Meijer (red.). Denken over vertalen. Tekstboek vertaalwetenschap. Nijmegen: Van Tilt, 2010, p. 189-196. Online op https://vertaalverhaal.nl/ project/de-vertaling-van-realia/.

Hayashi, Fumiko. "Downtown.” (1948). Vert. Luk Van Haute in Liefdesdood in Kamara (2014), p. 170-184. / Vert. Ivan Morris in Modern Japanese Stories. Charles E. Tuttle, 1962, p. 349-364.

Hiraide, Takashi. De kat (2001). Vert. Luk Van Haute. Amsterdam: Meulenhoff, 2015. / The Guest Cat. Vert. Eric Selland. New Directions, 2014.

Ichikawa, Takuji. Bij jou zijn (2003). Vert. Geert van Bremen. Amsterdam: Contact, 2011.

Inoue, Yasushi. "Kroniek van de overtocht naar Fudaraku." (1961). Vert. Luk Van Haute in Liefdesdood in Kamara (2014), p. 205-226.

Kawabata, Yasunari. Schoonheid en verdriet (1965). Vert. Luk Van Haute. Amsterdam: Meulenhoff, 2005. Kawakami, Hiromi. De tas van de leraar (2001). Vert. Luk Van Haute. Amsterdam: Atlas, 2010. / Der Himmel ist blau, die Erde ist weiß. Vert. Ursula Gräfe \& Kimiko Nakayama-Ziegler. Carl Hanser Verlag, 2008. / Les années douces. Vert. Elisabeth Suetsugu, Picquier 2005. / The Briefcase. Vert. Allison Markin Powell. Counterpoint, 2012.

Murakami Haruki. Dans dans dans (1988). Vert. Luk Van Haute. Amsterdam: Atlas, 2008. / Dance Dance Dance. Vert. Alfred Birnbaum. Kodansha International, 1994.

Slocombe, Will. "Haruki Murakami and the Ethics of Translation." CLCWeb: Comparative Literature and Culture 6.2 (2004), https://doi.org/10.7771/1481-4374.1232. Geraadpleegd 12 februari 2019.

Van Haute, Luk (samenstelling en vertaling), Liefdesdood in Kamara en andere Japanse verhalen. Amsterdam: Atlas Contact, 2014. 



\title{
2.3. \\ Vertaaltransformaties
}

\author{
Stella Linn
}

\section{Preliminaire overwegingen}

Voordat je als vertaler specifieke procedés gaat toepassen is het zinvol eerst na te denken over een globale vertaalstrategie aan de hand van vragen als: welk publiek staat je voor ogen, welk kennisniveau kun je verwachten, in hoeverre wil je een specifieke socioculturele context behouden? Dit speelt in het bijzonder bij kinder- en jeugdboeken, waarin soms een complete setting wordt overgeheveld naar de doelcultuur: een naturaliserende strategie. ${ }^{1}$ Ook intertekstuele verwijzingen kunnen voor keuzestress zorgen. ${ }^{2}$ Deze komen niet alleen voor in 'hoge' literatuur; zo worden in Franse jeugdromans waarin personages straattaal spreken geregeld ook gecanoniseerde dichters als Victor Hugo en Verlaine geciteerd (Linn 2014a: 68). Is het in zo'n geval goed om de verwijzingen via voetnoten of in een voorwoord te verklaren? Dat hangt onder meer af van je inschatting van het lezerspubliek en de wensen van de uitgever. Ook andere tekstoverstijgende eisen kunnen je vertaalstrategie sturen. Wordt de vertaling bijvoorbeeld gepubliceerd in een bepaalde reeks? Voor een educatieve uitgave zal op een aantal punten een andere keuze gewenst zijn dan wanneer de doeltekst voor een serie als 'Russische pareltjes uit de romantiek' bestemd is.

Macrotekstuele vertaalproblemen hebben vaak te maken met sociale normen, zoals verschillen in tolerantie ten opzichte van een taalfenomeen. Zo zijn schrijvers in Romaanse talen, en dat geldt ook wel voor het Engels, gewend om zich met meer retoriek en op een abstracter niveau uit te drukken dan Nederlanders (Linn \& Molendijk 2010: 15-25, Claes 2017: 67). Een bepaalde mate van formele vereenvoudiging of concretisering van elementen uit de brontekst kan dan ook

1 Zie ook hoofdstuk 3.6.

2 Zie ook 2.7 . 
relevant of zelfs nodig zijn. (Vlamingen zijn wellicht wat meer gewend aan de Franse stilistische conventies; voor vertalers uit Vlaanderen geldt dit dan alleen als zij hun werk in Nederland willen publiceren.) Reproductie van alle retorische middelen zou namelijk een schijnbaar equivalente, maar verhoudingsgewijs topzware doeltekst opleveren. Een voorbeeld hiervan in het klein zien we in de 'Romance de la Guardia Civil española' van de Spaanse dichter Federico García Lorca. Hierin wordt een dreigend beeld opgeroepen van de militaire politie die 's nachts te paard langsrijdt: (...) y ocultan en la cabeza / una vaga astronomía / de pistolas inconcretas (García Lorca 1996: 441). Bedoeld wordt niet dat de politieagenten in hun hoofd een theoretische studie van de sterren verbergen, maar een sterrenconstellatie aan schimmige pistolen, een niveau concreter dus. Andersom kan een Franse, Spaanse of Italiaanse versie van een Nederlandse brontekst vaak wat retorische aankleding gebruiken om te voorkomen dat deze al te simpel overkomt. Een apart probleem doet zich voor in het geval van contraintes, formele eisen die je opties in de hele doeltekst kunnen inperken of bepalen. Denk bijvoorbeeld aan een gedicht waarin slechts één klinker voorkomt (de 'o' in Vitalski's 'Hotdogoorlog'), of een graphic novel die maar beperkte tekstruimte biedt.

Reflectie op de initiële strategie is dan ook zinvol voordat je vertaalprocedés op een lager niveau gaat selecteren. Hieronder bespreken we een aantal frequente procedés die van microniveau (term, zinsdeel) naar macroniveau (de tekst als geheel) gaan. Houd er rekening mee dat een bepaald verschijnsel dat zich op lokaal niveau manifesteert verder reikende consequenties kan hebben.

\section{Woordniveau}

Op lokaal niveau moet je je allereerst bewust zijn van valse vrienden, woorden die bedrieglijk veel op elkaar lijken maar een geheel of gedeeltelijk andere betekenis hebben. Zo is de Duitse See in het Nederlands een meer en slaat das Meer juist op de zee. Het Spaanse colegio is in onderwijsland geen college van universitair niveau maar een basisschool (of lagere school), terwijl het Franse collège min of meer overeenkomt met de onderbouw van de Nederlandse middelbare school (in België zit het onderwijs iets anders in elkaar). Het vervolg hierop is het lycée, opnieuw een faux ami want dit heeft niet per se een vwo-niveau zoals het lyceum. Verder is het hierbij handig te weten dat in het Franse schoolsysteem van achteren naar voren wordt geteld. Als Wikipedia over de film Stella (Sylvie Verheyde 2008) vermeldt dat 
de elfjarige hoofdpersoon 'een nieuw schooljaar in de zesde klas op een chic lyceum [begint]' moet er dan ook een belletje gaan rinkelen: we hebben hier niet te maken met een genie maar met een doorsnee leerling die naar de brugklas (sixième) gaat.

Hiermee zijn we aangeland bij de realia, cultuurspecifieke begrippen die een beroep doen op impliciete kennis en daarom vaak een vertaalprobleem vormen. ${ }^{3}$ De meest voorkomende vertaalopties hiervoor zijn: handhaving van het begrip, al dan niet met een toelichting in de lopende tekst of eventueel een voetnoot, gebruik van een hyperoniem of algemener begrip, vervanging door een concept met een vergelijkbare functie in de doelcultuur of - als het niet anders kan - weglating. Soms is een aanpassing in de schrijfwijze nodig: Den Haag wordt in het Italiaans L'Aia, het Frans La Haye en in het Engels The Hague genoemd. Voor het omgaan met realia zijn goede zoekvaardigheden en een brede kennis van de broncultuur noodzakelijk. Zo kun je de lezer van een uit het Spaans vertaalde roman er subtiel op attenderen dat de namen Paco, Curro en Francisco alle drie naar hetzelfde personage verwijzen (de eerste twee zijn informele varianten), of je kunt met een kleine explicitering duidelijk maken dat Number 10 voor de ambtswoning van de Britse premier staat, informatie die bij vrijwel elke lezer uit de broncultuur bekend is. Een goede richtlijn is doorgaans de vraag welke vertaalstrategie in de doelcultuur het gewenste effect sorteert. Wanneer er in een Spaanse brontekst sprake is van de Reyes Magos kan het zijn dat de datum van deze feestdag relevant is: Driekoningen valt op 6 januari. Het kan er echter ook om gaan dat kinderen op die dag cadeautjes krijgen. Voor een kinderboek kan dit dan misschien adequater weergegeven worden met Sinterklaas of, in Vlaanderen, eventueel de Kerstman. Naast de denotatie, die naar een element in de buitenwereld verwijst, is hier dus de connotatie relevant, de associaties die met een begrip verbonden zijn (Grit 2010). De denotatie is meestal zonder probleem te achterhalen. Vooral bij connotaties kan het nuttig zijn navraag te doen op een taalforum met native speakers zoals Wordreference.com.

\section{Zinsdeel en zin}

Op het niveau van de zin kunnen we onder meer denken aan toepassing van transpositie, herschikking van zinsdelen, het splitsen van zinnen en aanpassing van de interpunctie. Transpositie ofwel omzetting van grammaticale categorie doet

3 Zie ook 2.2. 
zich bijvoorbeeld voor bij de vervanging van een actieve constructie, populair in Romaanse talen, door een lijdende vorm, zoals in Tout à coup, une vague énorme la projeta sur le pont: "Opeens werd ze door een enorme golf op het dek geslingerd." Zulke constructies met een onbezield onderwerp worden in het Nederlands ook regelmatig omzeild met behulp van een voorzetsel: Our study shows that ...: 'Uit ons onderzoek blijkt dat ...'. Verder worden Romaanse nominale constructies nogal eens omgezet naar werkwoorden. Nous considérons l'achat [de koop] d'un yacht wordt dan "We denken erover een jacht te kopen." De hiervoor genoemde omzetting van actief naar passief zou ook gerangschikt kunnen worden onder het begrip perspectiefwisseling, ook wel aangeduid als modulatie of antonymische vertaling. Dit houdt in dat een situatie of gebeurtenis in de brontaal bij voorkeur vanuit het ene gezichtspunt wordt gepresenteerd, terwijl in de doeltaal een andere invalshoek dominant is. Zo zeggen Spanjaarden eerder Me pagan por ello [ze betalen mij ervoor], waar Nederlandstaligen de handeling meestal vanuit het perspectief van de ontvanger belichten: 'Ik krijg ervoor betaald' (Linn \& Slager 2007: 192). Ook voor de volgorde van zinsdelen geldt dat je als vertaler de vrijheid hebt deze te herschikken als een andere syntaxis in de doeltaal gebruikelijker is. Vergelijk bijvoorbeeld de standaardpositie van plaats- en tijdsbepaling in respectievelijk het Frans en Nederlands: Champollion naquit à Figeac le 23 décembre 1790 / "Champollion werd op 23 december 1790 in Figeac geboren."

Over de zinslengte is bekend dat Romaanse taalgebruikers relatief lange zinnen produceren, mede door het gebruik van deelwoordconstructies. Ook het Engels kent die mogelijkheid: Sitting on the yellow carpet, drinking coffee, they wondered ... In het Nederlands, waar dit gebruik beperkt is, komt een letterlijke weergave vaak onhandig of omslachtig over. Het kan dan een goed idee zijn om de zinsstructuur te vereenvoudigen en lange zinnen af en toe te splitsen. Dit ligt natuurlijk minder voor de hand als een afwijkende zinslengte typerend is voor de stijl van een schrijver, zoals de voortmeanderende, soms paginalange zinnen van Thomas Mann of Carlo Emilio Gadda. In andere gevallen is het juist gewenst of noodzakelijk een elliptische structuur aan te vullen. In informeel Spaans kan een spreker zijn verhaal kernachtig afronden met Bueno, pues nada $\left[{ }^{*} \mathrm{Goed}\right.$, nou niks]. In onze taal is toevoeging van een werkwoordsvorm noodzakelijk: "Oké, dat was het." Let bij de weergave van gesproken taal ook op aanpassing aan formele conventies, zoals gebruik van leestekens; zo worden de aanhalingstekens in Nederlandse citaten in Franse en Spaanse teksten meestal omgezet naar een liggend streepje: "Je weet het nog niet," zei ze verbaasd. - No estás enterado, dijo sorprendida. 


\section{Tekstniveau}

Bij fenomenen die zich op tekstueel vlak manifesteren valt te denken aan stilistische variatie en de interpretatiemogelijkheden die de tekst biedt. De identiteit van literaire personages wordt mede geconstrueerd door de manier waarop ze zich uitdrukken. Deze kan variëren van formeel of archaïsch tot hippe straattaal. In feite hoef je niet exact te weten hoe iemand zich in de werkelijkheid uitdrukt, het gaat erom dat het taalgebruik van een verteller of personage bij het publiek geloofwaardig overkomt, dus passend bij zijn of haar fictionele identiteit. Relevante factoren hierbij zijn onder meer leeftijd en gender, geografische herkomst en sociaal milieu, bijvoorbeeld een vocabulaire dat past bij een laaggeschoold dan wel een erudiet personage. Vooral het vertalen van sociolect en dialect is lastig: enerzijds treedt er vervlakking of zelfs neutralisatie op wanneer je opvallende kenmerken telkens gladstrijkt, anderzijds kunnen doeltaallezers door al te gemarkeerde of exotiserende keuzes in de war raken. Vertalers kunnen hierdoor zelfs beschuldigd worden van culturele toe-eigening of ideologische manipulatie (Linn 2014b: 21). Vervanging door een herkenbaar dialect is dan ook een weinig toegepaste naturaliserende strategie. Meestal wordt geopteerd voor uitdrukkingen die een zekere afwijking van de standaardtaal suggereren, soms met een expliciete toevoeging als '... zei ze met een Provençaals accent'. Wees opnieuw alert op connotaties, ook met betrekking tot een bepaalde ideologie of religie; een streng islamitisch personage kun je beter niet een uitroep als 'allejezus!' in de mond leggen.

Geeft een tekst aanleiding tot meerdere interpretaties, probeer de ambiguiteit dan voor zover mogelijk ook in de doeltekst over te brengen. Symbolen kunnen bijvoorbeeld een bepaalde evocatieve waarde hebben die verloren gaat als je ze 'invult' door een expliciterende vertaling. In een gedicht van Herman de Coninck werd het vers "Trots. Marmer. Verdriet." voor Amerikaanse lezers vertaald als "Pride. Stubbornness. Sorrow." (Albers 2007: 53). Zo'n concretisering ontneemt de doeltaallezer de mogelijkheid zich zelfstandig een associatie bij het begrip 'marmer' te vormen. Anderzijds kan juist een verandering een meervoudige interpretatie veiligstellen en equivalentie op dat vlak waarborgen. Rutger Kopland richtte in $A l$ die mooie beloften een aantal gedichten, de 'G-cyclus' genoemd, aan een mysterieuze $\mathrm{G}$, over wie veel gespeculeerd is. Zou het om Gerda gaan, Gerard, God? We weten het niet. Vermoedelijk om die laatste optie in elk geval open te houden hanteerde de vertaler in het Frans de aanspreekvorm D, voor bijvoorbeeld Daniel, Dorothée - of Dieu (Kopland 1986). 
Wanneer een bijzonder effect noodgedwongen wegvalt, passen ervaren vertalers vaak compensatie toe. Daarbij wordt een verlies op een bepaald punt als het ware goedgemaakt door een element met een vergelijkbare waarde elders in de vertaling te integreren, zodat het effect in de tekst als geheel ongeveer gelijk blijft. Een voorbeeld: in het Nederlands of Duits kun je door iemand te tutoyeren een verschil in hiërarchie of mate van vertrouwelijkheid uitdrukken. Dit gaat niet op dezelfde manier in het Engels, waar you zowel 'u' als 'jij' kan betekenen. Een vertaler zou dan iemands voornaam kunnen invoegen of een informele taalvariant als you're in plaats van you are gebruiken (Delisle et al. 1999: 126). Ook bij het reproduceren van een functionele fout (Linn \& Molendijk 2010: 23) kan compensatie van pas komen. Zo kan een laaggeletterd personage gekenmerkt worden door onbeholpen of incorrect taalgebruik. In onze taal kun je bijvoorbeeld 'heb' voor de derde persoon gebruiken of dt-fouten invoegen: "Ze schreef in haar brief: 'hij heb het zelf gezegt'."

Om de stilistische vervlakking die in vertalingen kan optreden tegen te gaan kun je ook -gedoseerd - strooien met taalgebonden idiomatische kenmerken, die doorgaans dus niet gemotiveerd worden door de brontekst. Denk voor het Nederlands bijvoorbeeld aan het gebruik van 'er' ter aankondiging van het onderwerp: 'Er komt iemand aan', modale partikels zoals 'wel' of 'even' en, vooral in een informeel register, verkleinwoorden ('lekker weertje!'). Een voorbeeld: de gebiedende wijs heeft in Romaanse talen een ruimere gebruiksmogelijkheid dan in onze taal, waar deze vorm al gauw autoritair overkomt. Je kunt dan prettig nuanceren met een of meer modale partikels: "Loopt u maar even mee." Ook formuleren Nederlandstaligen in zo'n situatie vaak een vraagzin: "Wilt u even meelopen?"

Kortom, we kunnen zowel op micro- als op macroniveau concluderen dat vertalen een voortdurende zoektocht is naar de ideale balans tussen verlies en verrijking. 


\section{Bibliografie}

Albers, Frank. "Herman de Coninck in Amerika." Filter, tijdschrift over vertalen 14:4 (2007), p. 51-56.

Claes, Paul. Gouden vertaalregels. Nijmegen: Vantilt, 2018.

Delisle, Jean, Hannelore Lee-Jahnke en Monique Cormier. Terminologie de la traduction / Translation Terminology / Terminología de la Traducción / Terminologie der Übersetzung. Amsterdam/ Philadelphia: John Benjamins, 1999.

Dorst, Aletta G., Bert Weltens en Mike Hannay. Van tekst naar text. Taal-en vertaalvaardigheid Engels. Muiderberg: Coutinho, 2014.

García Lorca, Federico. Obras completas I: Poesía. Ed. Miguel García-Posada. Barcelona: Galaxia Gutenberg \& Círculo de Lectores, 1996.

Grit, Diederik. “De vertaling van realia.” In Naaijkens, Ton et al. (red.), Denken over vertalen, tekstboek vertaalwetenschap. Nijmegen: Vantilt, 2010/2004, p. 189-196.

Kopland, Rutger, 1986. Songer à partir (vert. Paul Gellings). Paris, Gallimard.

Lemmens, Marcel en Tony Parr. Handboek voor de vertaler Nederlands-Engels. Groningen: Wolters-Noordhoff, 1995.

Linn, Stella. "Het vertalen van straattaal (I)." Filter, tijdschrift over vertalen 21:3 (2014a), p. 63-70.

Linn, Stella. "Het vertalen van straattaal (II)." Filter, tijdschrift over vertalen 21:4 (2014b), p. 21-36.

Linn, Stella en Miel Slager. Vertalen uit het Spaans, tekst en uitleg. Muiderberg: Coutinho, 2007.

Linn, Stella en Arie Molendijk. Vertalen uit het Frans, tekst en uitleg. Muiderberg: Coutinho, 2010. 



\title{
2.4 . \\ Creatief vertalen
}

\author{
Harm Damsma
}

In december 2015 werden de Literaire Vertaaldagen in Amsterdam gehouden onder het motto 'Verzinnen wat er staat' en het jaar daarop werd het evenement gehouden met als thema 'De vertaler als schrijver'. Beide slogans suggereerden een grotere creatieve inbreng van de vertaler in het vertaalproces en meer artisticiteit en zelfstandig kunstenaarschap dan de praktijk doorgaans rechtvaardigt. Het leek wel alsof de te vertalen tekst enkel werd gezien als een inspiratiebron voor gemankeerde schrijvers die om een plot verlegen zitten, een aangrijpingspunt om de persoonlijke schrijfdrift naar eigen stilistische inzichten te kunnen botvieren.

Natuurlijk, van kreten als 'Kopiëren wat er staat' of 'De vertaler als afschrijver' zou weinig wervends zijn uitgegaan, maar toch is dat waar vertalen in de praktijk op neerkomt: nauwgezet in de eigen taal weergeven wat er in de vreemde taal wordt beweerd. En wie in zijn vertaling aankomt met zinnen als 'Verkoudheid is een gek zinnebeeld voor een onvergolden liefde', of een personage bepaalde leugens 'haakje, snoer en dobber' ('hook, line and sinker', oftewel: van A tot Z) laat slikken, ontbreekt het niet zozeer aan creativiteit als wel aan kennis, inzicht en vakmanschap. ${ }^{1}$

Want laten we de zaak niet romantischer voorstellen dan ze is: vertalen is in de eerste plaats een vak als de meeste andere, waarvoor een ruime aanleg is vereist, waarvoor je over allerlei praktische, aan te leren vaardigheden moet beschikken en dat meer met geconcentreerde routine dan met bevlogen kunstenaarschap wordt uitgeoefend. Popartkunstenaar Andy Warhol, die zijn studio in New York The Factory noemde, zei het al: "It's work."

Maar net als een loodgieter, een accountant of een hersenchirurg wordt ook een vertaler op gezette tijden geconfronteerd met onverwachte situaties en onvoorziene

1 Beide voorbeelden zijn, naast talloze andere, niet minder curieuze te vinden in de vertaling van The Wives of Bath (1993) van Susan Swan: Genadeloze meisjes (1996). 
problemen die met het gewone, alledaagse vakmanschap niet kunnen worden opgelost en waarvoor een inventieve aanpak is vereist. En over die momenten handelt dit hoofdstuk.

Helaas is creativiteit een aangeboren eigenschap, niet iets wat je kunt leren, en het zal hier dan ook niet gaan over de vraag: hoe word ik creatief? Wel wordt in de komende bladzijden geschetst waardoor die 'problemen' die een beroep doen op het improvisatietalent van de vertaler meestal worden gecreëerd, hoe je dergelijke problemen analytisch kunt benaderen en in welke richtingen je soms kunt zoeken naar een oplossing die recht doet aan in elk geval de belangrijkste aspecten. Maar voor de rest is creatief vertalen vooral een kwestie van kaarsen branden en hopen op een geniale inval.

Tot slot een algemeen advies: ga, om je talent aan te scherpen, vooral te rade bij de meesters op hun gebied. Vandaar dat je in dit hoofdstuk veel voorbeelden zult tegenkomen van gevallen waarbij een creatieve benadering gevraagd wordt. Dat die voorbeelden hoofdzakelijk ontleend zijn aan de Engelstalige literatuur, komt simpelweg doordat ik daar het beste in thuis ben.

\section{Vormproblematiek}

Goed, vertalen is zo nauwgezet mogelijk in de eigen taal weergeven wat in de vreemde taal wordt beweerd, schreef ik daarnet weinig wetenschappelijk, en als dat de enige bedoeling van de vertaalhandeling was zou dat in principe altijd mogelijk moeten zijn. Immers, desnoods kan een alinea van 8 regels worden weergeven in 16 pagina's dichtbedrukte tekst, voorzien van 26 verklarende voetnoten. ${ }^{2}$ Maar het overbrengen van de inhoud alleen is vrijwel nooit genoeg.

Want impliciet stellen wij als eis aan een vertaling dat de mededeling niet alleen inhoudelijk correct wordt overgebracht naar onze taal, maar dat dat ook gebeurt 'op de manier waarop wij dat zouden zeggen'. ${ }^{3}$ Met andere woorden: de inhoud van een vertaalde tekst moet corresponderen met die van de brontekst maar de vorm met

2 De vraag wat de exacte inhoud van een taaluiting nou precies ís (met alle bijkomende nuances en connotaties van dien) laat ik hier gemakshalve onbesproken.

3 Trouwens, zo impliciet is die eis helemaal niet. Het zogeheten modelcontract vraagt immers van de vertaler dat hij/zij "een naar inhoud en stijl getrouwe en onberispelijke vertaling” moet leveren. Zie ook hoofdstuk 1.1. 
die van de doeltaal. En het is de vórm die ons, literair vertalers, op gezette tijden de nodige creatieve hoofdbrekens bezorgt.

Het literaire gehalte van een tekst wordt immers in belangrijke mate medebepaald door de vorm, de stijl of stijlen waarin die is verpakt. Om te beginnen moet de vertaler dus een scherp oog hebben voor stijlkenmerken en een goed oor hebben voor zinsritmiek.

\section{Zinsritmiek}

Om met dat laatste te beginnen: niet alleen in poëzie, maar ook in proza kom je soms passages tegen waarvan de zinnen een sterk ritmische inslag hebben. Een fraai staaltje vind je bijvoorbeeld in het eerste hoofdstuk van de roman Purple America (1997) van Rick Moody. Na een korte, plechtige openingszin - "Whosoever knows the folds and complexities of his mother's body, he shall never die" - volgt een lange, litanische zin die in totaal maar liefst vijf dichtbedrukte bladzijden beslaat:

Whosoever knows the latitudes of his mother's body, whosoever has taken her into his arms and immersed her baptismally in the first-floor tub, lifting one of her alabaster legs and then the other over its lips, whosoever bathes her with Woolworth's soaps in sample sizes, whosoever twists the creaky taps and tests the water on the inside of his wrists, etc.

om daarna te worden afgerond met twee korte zinnetjes van samen amper twee regels.

De onmiskenbaar bezwerende cadans van de ellenlange zin, waarvan Moody later in een interview bekende dat hij die had geschreven bij steeds dezelfde repetitieve muziek, wordt hier en daar nog versterkt door allerlei klankovereenkomsten en alliteraties, zoals hier bijvoorbeeld met "lifting one of her alabaster legs and the other over its lips", "soaps in sample sizes" en "twists the creaky taps and tests the water". De vertaler moet daarop gespitst zijn en in het Nederlands een vergelijkbaar ritme zien te vinden, en lukt het hem niet de gewenste klankondersteuning ter plekke aan te brengen, dan doet zich misschien elders in de passage een compensatoire kans voor. 


\section{Stijlfiguren}

Over stijlfiguren ${ }^{4}$ kunnen we in principe kort zijn: die corresponderen (wat het gros van de West-Europese talen betreft) grotendeels met wat wij in onze taal in de literatuur gewend zijn en leveren in principe weinig problemen op. Alleen bij beeldspraak moet de vertaler zich afvragen of het beeld een cliché is of een oorspronkelijke, door de auteur verzonnen metafoor. In het eerste geval zal hij een overeenkomstige gemeenplaats moeten zoeken ("Chi di gallina nasce convien che razzoli" - "De appel valt niet ver van de stam"), in het tweede kan hij de auteur gewoon navolgen, zelfs als diens beelden in zijn ogen wat al te baldadig zijn of zelfs niet kloppen.

Eén bijzonder geval verdient in dezen nog vermelding. In bepaalde Brits-Engelse teksten kun je worden geconfronteerd met zogeheten rhyming slang, een typisch Britse, grootstedelijke stijlfiguur, waarbij het bedoelde woord wordt vervangen door een woord dat erop rijmt maar er qua betekenis vaak weinig mee uitstaande heeft. Adam and Eve staat dan bijvoorbeeld voor believe, He was Brahms and Liszt voor $\mathrm{He}$ was pissed (d.w.z. dronken), baked bean voor queen en aunt Joanna voor piano.

Zo wordt in de roman Trainspotting (1993) van de Schotse schrijver Irvine Welsh, waarvan het verhaal zich afspeelt in de drugsscene van Edinburgh, de felbegeerde speed aangeduid met de term Lou Reed (hier is de link tussen de gebezigde term (de eigennaam van een bekende popmuzikant) en het woord waar die voor staat overigens allesbehalve obscuur). En in Anthony Burgess' roman A Clockwork Orange (1962), waarover later meer, dragen vier vrienden, wanneer zij de stad in trekken om zich te buiten te gaan aan wat zij ultra-violence noemen, ter bescherming van hun edele delen een toque (door hen aangeduid als jelly mould oftewel puddingvorm), en hoofdpersoon/verteller Alex vindt die van de ietwat sullige Dim 'very hound-and-horny'. Dat laatste staat (rijmend) voor corny, wat zoiets als banaal of afgezaagd betekent.

Het is duidelijk dat deze stijlfiguur in het Nederlands geen pendant kent en dus niet letterlijk kan worden nagevolgd. Dat houdt in dat een vertaler steeds van geval tot geval moet bekijken welke spitsvondige draai hij aan het voorkomende rhyming slang kan geven, het liefst natuurlijk zoveel mogelijk aansluitend bij contextuele aspecten. In het geval van 'hound-and-horny' bedachten de vertalers (met het oog op de functie die de toque moet vervullen) het adjectief 'ouballig', dat qua betekenis dicht bij 'afgezaagd' staat en ook aansluit bij andere woordvormingsprincipes die Burgess verder toepast (ook daarover straks meer). 
Doordat rhyming slang in onze taal een onbekend fenomeen is zijn Nederlandse vertalers over het algemeen niet zo ingesteld op (het herkennen van) het verschijnsel. Het verdient dan ook aanbeveling om, als je in een Britse grote-stadsroman op een woord(combinatie) stuit die volkomen out of context lijkt, na te gaan of het misschien om een geval van rhyming slang gaat en in dat geval proberen te achterhalen waar de term voor staat. Voor de daaropvolgende inventieve verwerking zijn dan, zoals gezegd, geen verdere richtlijnen te geven.

\section{Neologismen}

Ook neologismen ${ }^{5}$, door een auteur zelf verzonnen woorden, doen een enkele keer een beroep op de creativiteit van de vertaler. Een kras voorbeeld levert opnieuw $A$ Clockwork Orange. Hoofdpersoon Alex doet zijn relaas namelijk in een zelfgebrouwen taaltje dat een ietwat infantiele mengeling is van rhyming slang (zie boven), jongerentaal uit de jaren vijftig, meer dan tweehonderd van oorsprong Russische woorden en termen die door het personage zelf zijn bedacht of geconstrueerd. Het gaat om kinderlijk aandoende brabbelwoordjes (zoals baddiwad, van bad (slecht), of guttiwuts, van guts (ingewanden), die zich gemakkelijk laten vernederlandsen tot bijvoorbeeld rottemetot en buikepuik. Het principe is geënt op een in de Engelse kinderkamer (maar ook bij ons) gangbare praktijk. Zo lezen wij in de roman Wish You Were Here van Graham Swift over een stel Britse militairen in Irak die na een patrouille onderweg zijn naar hun basis, 'dog-tired, to do beddy-byes', om slapies te gaan doen dus.

Verder vind je in het Nadsat (want zo wordt Alex' taaltje genoemd) allerlei associatieve neologismen als barry place (voor gevangenis, dus zeg maar traliehok; bars zijn tralies) en onomatopeïsche werkwoorden, zoals to boohoohoo voor huilen, wat in het Nederlands vrijwel automatisch boehoehoeën wordt.

Een aparte categorie vormen de prachtige, uiteraard in geen enkel woordenboek te vinden, vlechtwoordconstructies die Burgess Alex laat creëren. Het zijn woorden als to chumble (een vervlechting van to chatter en to mumble) en to crark (van to crow en to bark). Dat zouden respectievelijk klompelen (van kletsen en mompelen) en (kraffen van kraaien en blaffen) kunnen worden.

$5 \quad$ Zie ook 2.2., 2.6., 3.1. 


\section{Woordspelingen}

Wat steeds weer een beroep doet op de creativiteit van een vertaler is humor, met name als het gaat om woordspelingen ${ }^{6}$. Een simpel voorbeeldje. In de Britse cult classic A Kestrel for a Knave (1968) van Barry Hines wordt de sadistische schooldirecteur Gryce, die zijn leerlingen nog lijfelijk straft met een Spaans rietje, achter zijn rug om 'Gryce pudding' genoemd (niet op grond van's mans zwaarlijvigheid maar vanwege de klankovereenkomst met rice pudding). Wat doen wij? Hetzelfde principe toepassen gaat niet, vanwege het ontbreken van de Engelse ai-klank in het Nederlands. Welke andere manieren om tot een bijnaam te komen hebben wij? Allitereren wij? 'Griezel Gryce' of 'Gryce Graftak'? (En is dat eigenlijk geen optisch bedrog, gezien het klankverschil tussen de Engelse en de Nederlandse 'g'?) Of doen wij iets met het sadistisch karakter van de man? Laat je gedachten er eens over gaan.

In zijn roman The Thousand Autumns of Jacob de Zoet (2010) speelt auteur David Mitchell met het feit dat sommige Aziaten het verschil niet horen tussen de Europese letters 'r' en ' 'l'; voor hen zijn het varianten van hetzelfde foneem. In het verhaal, dat zich afspeelt in 1799 op het eilandje Deshima bij Nagasaki, waar de VOC als enige westerse handelsonderneming toegang had tot het verder geïsoleerde Japan, verontschuldigt het titelpersonage zich op zeker moment tegenover een Japanse vrouw voor eerder lomp gedrag. Hij had namelijk in de veronderstelling verkeerd dat ze een concubine was - andere vrouwen werden niet op het eiland toegelaten - en haar als zodanig behandeld. Inmiddels weet hij dat zij een hoogopgeleide vroedvrouw is en hij zegt: "Please forgive me my rudeness, miss." Waarop de vrouw antwoordt: "I sorry. Excuse my lewdness?" 'Lewd' betekent in het Engels 'wulps', 'wellustig.?

Beroemd en berucht om de vele woordspelingen die erin voorkomen is het boek Alice's Adventures in Wonderland (kortweg bekend als Alice in Wonderland, 1865) van Lewis Carroll (pseudoniem van Charles Dodgson). Velen hebben daarin een uitdaging gezien en het is dus geen wonder dat er in de loop van de tijd ettelijke Nederlandse vertalingen van zijn verschenen. De laatste mij bekende is die van Nicolaas Matsier, die over de schrijver, het werk en het vertalen ervan (uiteraard ook van alle puns) een inzichtrijk boek(je) schreef onder de titel Alice in Verbazië.

6 Zie ook 2.6., 3.2., 3.6.

7 Wie wil weten tot welke 'oplossing' de vertalers van het boek zijn gekomen kan dat nagaan in De niet verhoorde gebeden van Jacob de Zoet (2010). 
Bekijk zelf maar eens, met Matsiers boekje bij de hand, de begripsverwarring rond de woorden 'tale' en 'tail', en bedenk daarbij dat een vertaler hoe dan ook vastzit aan de betekenissen 'verhaal' en 'staart' omdat de geschiedenis van de muis typografisch wordt weergegeven in de vorm van een kronkelende staart.

En wat te denken van wat de Mock Turtle (wiens naam alleen al om een creatieve benadering vraagt) vertelt over alle vakken die hij op school heeft gevolgd? De kracht van de opeenstapeling van woordgrappen in die passage is gelegen in de grote natuurlijkheid ('Seaography' verschilt ook qua klank nauwelijks van 'Geography', 'Laughing and Grief' nauwelijks van 'Latin and Greek') waarmee ze worden gedebiteerd. Dat het niet altijd meevalt in de vertaling een vergelijkbare vanzelfsprekende nonchalance te vinden bewijzen de verschillende Nederlandse versies van Alice.

Dat taalgevoelige kinderen als Alice Liddell, de jonge muze van Dodgson, genieten van dit soort woordspelletjes hebben meer jeugdboekenschrijvers begrepen. In Winnie-the-Pooh (1926) van A.A. Milne neemt het jongetje Christopher Robin (Janneman Robinson) op zeker moment zijn speelgoedvriendjes mee op ontdekkingstocht 'to discover the North Pole'. Maar ja, wat ís die North Pole eigenlijk? 'Just a thing to discover,' zegt Christopher Robin achteloos; hij weet het ook niet precies. Het is ten slotte beer Winnie - hij kent het woord 'pole' naar blijkt alleen in de betekenis van 'paal' - die het vermaledijde ding vindt, waarna hij passend met een plaquette voor zijn ontdekking wordt geëerd: "North Pole. Discovered by Pooh. Pooh Found It."

Voor het hier gecreëerde woordgrapje, waar kinderen die het doorhebben vergenoegd om kunnen gniffelen, is bij mijn weten in een Nederlandse vertaling nooit een doeltreffende oplossing gevonden. Dus wat let je.

\section{Dialect en streektaal}

Een interessant beroep op onze creativiteit wordt er gedaan wanneer er in een roman een dialect of streektaal wordt gesproken. ${ }^{8}$ Hoewel in onze vertalingen alle personages altijd (een vorm van) Nederlands spreken, zijn ze niettemin voor de lezer stuk voor stuk volbloed Amerikanen, Zweden, Senegalezen of what have you. Sterker nog, in de beleving van de lezer spreken ze zelfs helemaal geen Nederlands maar gewoon Engels, Zweeds of Frans. 
Maar neem nu een Britse roman waarin een vrouw voorkomt die met een sterk Welsh accent spreekt. De vertaler heeft dat trachten weer te geven door haar WestVlaams te laten 'klappen'. En wat gebeurt er? In de beleving van de lezer is de vrouw niet iemand geworden die in haar spraak haar Welshe afkomst verraadt, maar een figuur die weggelopen lijkt uit een liedje van Wannes Cappelle of Flip Kowlier (“Ne welhemeende 'Fuck you!'”). Blijkbaar lukt het West-Vlaams niet wat het standaard-Nederlands moeiteloos lukt: de illusie wekken van een andere taal. Kennelijk is de poging om Vlaams regiolect te laten doorgaan voor een Britse streektaal voor ons een brug te ver. Waarom dat zo is, waarom het ene wél werkt en het andere niet? Ik zou er geen verklaring voor weten. Maar feit is dat een dergelijke transformatie een tegendraads effect heeft.

Daarom wordt vertalers over het algemeen aangeraden regiolect zoveel mogelijk te neutraliseren en hooguit een paar kleine naar streektaal zwemende accentjes aan te brengen. Afgezien van de vraag of neutraliseren echt altijd onvermijdelijk is: als het gebeurt, is dat op zijn minst heel spijtig. Want als het goed is, heeft afwijkend taalgebruik in een verhaal of roman een duidelijke functie. De personages worden er, zonder dat nadere uitleg of omschrijving nodig is, door getypeerd voor wat betreft hun afkomst, sociale achtergrond, opleidingsniveau en dergelijke. En in veel gevallen illustreert en onderstreept het dusdoende thematische aspecten. Een voorbeeld.

In de in mijn ogen even gekunstelde als sentimentele roman Holly (1995), van Albert French, heeft de vertaler de markante taalverschillen die zich in het boek voordoen nagenoeg geheel wegvertaald. In dit geval lijdt de thematiek van het boek daar ernstig onder. Het verhaal speelt zich af in het zuiden van de Verenigde Staten. Het is 1944, een tijd waarin rassenscheiding nog hoogtij viert. Het contrast waar het hier om gaat is dat tussen een zwarte, uit Washington afkomstige, correct sprekende, intellectuele familie en de witte, plat pratende, geborneerde inwoners van een achterafgat in North Carolina. ("Ya tell Elsie, Ah got a bone ta pick wit her. Tell her, she better git down here and see me. Ya tell her Ah said that, ya hear?" - "Zeg maar tegen Elsie dat ik nog een appeltje met haar te schillen heb. Zeg maar dat ze eens heel gauw bij me langs komt. Zeg maar dat ik het gezegd heb, hoor je me?")

Het zal duidelijk zijn: het vertalen van regiolect is een heikele kwestie. Is er überhaupt een manier om in dezen zalig te worden? Is het mogelijk om in het Nederlands (!) duidelijk te maken dat iemand negentiende-eeuws Iers spreekt met een New Yorks accent? Algemener gesteld: bestaat er een manier om vertalenderwijs recht te doen aan de informatieve waarde en het mogelijk thematisch belang van gemarkeerd regiolect, zonder dat het welbewust opgeschorte ongeloof van de lezer 
wordt aangevochten? Ik denk het wel, al zullen de mogelijkheden van geval tot geval aanzienlijk verschillen.

Eén ding is in elk geval duidelijk: we moeten vermijden dat een dialect in vertaling traceerbaar is naar een specifieke plaats of regio in Nederland of Vlaanderen, maar als het even kan wel een soort algemeen plat creëren, met niet-streekspecifieke kenmerken. Kleine spellingsingrepen (m'n, z'n, d'r) kunnen daarbij soms al helpen, evenals het maken van algemeen-platte fouten, zoals het verwisselen van 'kunnen' en 'kennen' of 'liggen' en 'leggen', en constructies als 'groter als'. Van één ding zal een vertaler zich daarbij bewust moeten zijn, namelijk dat er verschillen zijn tussen grootsteedse dialecten en streektalen van het platteland. En dat hij dus nooit een Cockney op zijn plat Gronings allerlei woorduitgang'n moet lat'n inslikk'n, of een bejaarde inwoner uit het Toscaanse Loro Cuiffenna Haags laten wauze.

Tot slot nog een opmerking over het weergeven van het black English dat je in tal van Amerikaanse romans zult tegenkomen. Natuurlijk wil je dat niet verdoezelen of neutraliseren, maar je personages Surinaams of Congolees laten spreken gaat (om bovengemelde reden) niet. En ze een soort zwartepietentaaltje in de mond leggen is helemaal uit den boze: het zou de personages - vaak alleszins weldenkende, verstandige personen - onbedoeld debiliseren of een komieke uitstraling geven.

Een goed advies in dezen is: ga bij geval eens te rade bij het boek I $\mathrm{ga}$ dood om jullie hoofd (1980) van de Surinaamse Nederlander / Nederlandse Surinamer Edgar Cairo. Cairo voelde zich een ontheemde tussen twee culturen en schiep voor zijn literaire werk een eigen schrijftaal gebaseerd op Sranan Tongo, Surinaams Nederlands en ABN. Uit de vele voorbeelden daarvan die de auteur in voornoemd boek zelf bespreekt (p.30-38) zou je een zorgvuldige keuze kunnen maken om een niet lokaliseerbaar 'zwart Nederlands' te creëren.

\section{Poëzie en liedteksten}

Naarmate de vorm dwingender is, neemt de één-op-één-vertaalbaarheid van een tekst af en wordt het beroep dat er op de creativiteit wordt gedaan dus groter. Dat blijkt natuurlijk vooral bij het vertalen van vormvaste, rijmende, metrische poëzie. ${ }^{9}$ Een sonnet van Shakespeare is heel wat lastiger te vertalen dan een veertienregelig

9 Zie ook 3.2. 
verhaal van Lydia Davis (al zitten aan dat laatste ook nog best de nodige haken en ogen).

Shall I compare thee to a Summer's day?

Thou art more lovely and more temperate.

Rough winds do shake the darling buds of May,

And Summer's lease hath all too short a date;

Dit is het begin van een overbekend sonnet. Twee coupletten van vier regels en twee van drie. Staand, gekruist rijm. En een metrum van vier trocheïsche versvoeten plus een beklemtoonde lettergreep aan het eind. De vertaler die de inhoud van het gedicht in alle opzichten equivalent wil weergeven en tegelijk aan alle pasgenoemde vormvoorschriften wil voldoen, heeft een probleem, en geen kleintje ook. Als hij zich aan de vorm houdt zal hij bij het weergeven van de inhoud (al dan niet knarsetandend) tal van concessies moeten doen en bepaalde betekenisaspecten moeten laten vallen.

Shakespeare's sonnetten hebben van oudsher een grote uitdaging gevormd voor vertalende dichters en dichtende vertalers en er zijn dan ook heel wat die zich aan een vertaling hebben gewaagd. Hoe gingen zij te werk? Dachten ze vanuit de inhoudelijk correcte weergave van de eerste regel of zochten ze om te beginnen eerst naar geschikte rijmwoorden door het hele vers heen? Welke inhoudelijke of formele vrijheden veroorloofden ze zich? Zat er enige method in their madness? Vaak is hun benaderingswijze af te leiden uit het eindresultaat, en voor wie bij hen de kunst hoopt af te kijken is vergelijkend warenonderzoek dus ook hier de aangewezen weg.

Een meer dan royaal overzicht van alle pogingen om (een deel van) de 154 gedichten in het Nederlands weer te geven biedt de website "Shakespeares sonnetten; interpretatie en vertaling” van vertaler Frank Lekens (Lekens s.d.). Naast diens eigen 'maaksels' en het nog steeds toenemende aantal vertalingen van gedreven amateurs vind je daar een aanbod dat varieert van Boutens tot Burgersdijk, van Verwey tot Verstegen en van Paul Claes tot H.J. de Roy van Zuydewijn.

Maar niet alleen het vertalen van complexe, hooggestemde poëzie vraagt veel creativiteit, ook bij het vernederlandsen van de betere popsongs komt veel inventiviteit kijken. Daarbij zijn, naast metrum en rijm, melodie en zingbaarheid complicerende factoren. Daar staat tegenover dat de spelregels inzake getrouwe weergave vaak ruimer zijn. Erkende meesters op dit terrein zijn Robbert-Jan Henkes en Erik Bindervoet. Zij vertaalden niet alleen werk van Joyce en Shakespeare, maar ook een groot deel van het oeuvre van Nobelprijswinnaar Bob Dylan $(2016,2017)$, 
inclusief diens experimentele roman Tarantula (2017) en alle songs van The Beatles (Bindervoet en Henkes 2003). Bij hen kun je alles leren over het vertalen van songs naar de letter (I Am the Walrus - Ik ben de walrus), naar de klank (We Can Work It Out - Weekend wordt het koud) of naar de geest (Sgt. Pepper's Lonely Hearts Club Band-Captain Iglo's Zeemanszangzaadkoor).

Maar ook van Jan Rot valt op het gebied van het vertalen van liederen veel te leren. Deze zanger, componist en tekstdichter bundelde al zijn popvertaling in Rot voor u (2010) dat verscheidene, steeds uitgebreidere edities kende, en waarin je onder meer kunt nagaan hoe verrassend nauwkeurig Rot de inhoud van songs als A Boy Named Sue van Johnny Cash (Mijn naam is Mien), Graceland van Paul Simon (Graceland) of I Am, I Said van Neil Diamond (Zeg God ... zeg ik) binnen de gegeven vorm weet weer te geven.

En wie het Haags machtig is (en van flamencomuziek houdt) moet beslist eens kennisnemen van het werk van Johan Frauenfelder, de singâhsongrègâh van het muziekgezelschap De Règâhs (met een knipoog vernoemd naar de ooievaar in het stadswapen van's Gravenhage). Ook hij vertaalde voor zijn groep allerlei popsongs in zijn moerstaal, waaronder zestien nummers van Lennon en McCartney voor de cd BES-TOF DE BEATLES. Een leerzame aanrader, al is het alleen maar om je te verbazen over de geniale inval die Frauenfelder ertoe bracht om Norwegian Wood om te zetten in Noordwijkerhout (nou ja, in Noâhdwèkaghâht, of zo). Waar Rot en Bindervoet \& Henkes niet verder kwamen dan respectievelijk Ikea kast en Veluwezoom.

\section{Rederijkerij}

Maar denk niet dat dwingende rederijkerij beperkt blijft tot de dicht- en liedkunst. Lees bijvoorbeeld eens onderstaande prozapassage.

1

Qui, d'abord, a l'air d'un roman jadis fait où il s'agissait d'un individu qui dormait tout son saoul.

Anton Voyl n'arrivait pas à dormir. Il alluma. Son Jaz marquait minuit vingt. Il poussa un profond soupir, s'assit dans son lit, s'appuyant sur son polochon. Il prit un roman, il l'ouvrit, il lut; mais il n'y saisissait qu'un imbroglio confus, il butait à tout instant sur un mot dont il ignorait la signification. 
Il abandonna son roman sur son lit. Il alla à son lavabo; il mouilla un gant qu'il passa sur son front, sur son cou.

Son pouls battait trop fort. Il avait chaud. Il ouvrit son vasistas, scruta la nuit. Il faisait doux. Un bruit indistinct montait du faubourg. Un carillon, plus lourd qu'un glas, plus sourd qu'un tocsin, plus profond qu'un bourdon, non loin, sonna trois coups. Du canal Saint-Martin, un clapotis plaintif signalait un chaland qui passait.

Wie het boek waarvan dit de openingsalinea's zijn niet kent, valt mogelijk in eerste instantie niets bijzonders op. Goed, de passage doet op de een of andere manier wat stijf aan, met al die vrij korte hoofdzinnetjes. Maar waar is die dwingende vorm? Wat makt het zo'n heidense uitdaging voor een vertaler?

Welnu, er ontbreekt iets in deze roman. Georges Perec, de auteur, schreef het boek, dat in 1969 uitkwam en meer dan driehonderd bladzijden telt, zonder ook maar één keer de vijfde letter van het alfabet te gebruiken. Een literair huzarenstukje? Of louter gimmick, spielerei, gezochte rederijkerij? Op zichzelf genomen is La Disparition, want zo heet de roman, een soort whodunit. Want hoofdpersoon Anton Voyl verdwijnt op zeker moment spoorloos van de aardbodem. En met hem blijkt ook het vijfde (!) hoofdstuk van het boek vermist. Het ontbreekt simpelweg in het boek, wat doet vermoeden dat de lezer - en de personages die naar Voyl op zoek gaan - cruciale informatie wordt onthouden. Wat volgt is een schimmige zoektocht naar de vermiste, waarbij een stoet vermakelijke figuren de revue passeert en mensen het loodje leggen telkens als ze iets van de waarheid lijken te achterhalen.

Maar het boek is ook een worsteling met taal. Want naast de practical joke met de ontbrekende letter zit het boek nog vol andere taalspelletjes met letters, woorden en betekenissen. Verder word je als lezer verondersteld bekend te zijn met het werk van Poe, Flaubert, Borges en tal van andere literaire grootheden. Perec citeert, parodieert, epateert, en of dat grootse literatuur heeft opgeleverd moet je zelf maar beoordelen.

Maakt nu - als we ons even tot dat aspect beperken - het ontbreken van de letter 'e' dit boek onvertaalbaar? Blijkbaar niet, want inmiddels kennen wij Anton Voyls Fortgang, A Void, La Scomparsa en nog tal van andere vertalingen, waaronder zelfs die in het Russisch en in het Chinees. De Spaanse vertaling heet echter opvallend genoeg El secuestro, want daarin is het de letter 'a' die ontbreekt, omdat dat in die taal de meest voorkomende letter is. De link met het getal vijf is daarbij dus opgegeven.

Als we naar onze eigen taal kijken, waar zitten bij een vertaling van La Disparition dan de problemen? Om te beginnen kan de Nederlandse vertaler over geen enkel lidwoord (de, het, een) beschikken. Perec daarentegen kon zich bedienen van 
het vrouwelijke bepaald lidwoord (la), de l-apostrof en het mannelijke onbepaald lidwoord (un). Hij had dus nog ruime keus. Verder moet de Nederlandse vertaler afzien van het gros van de infinitieven en alle vormen van de verleden tijd van zwakke werkwoorden: het verhaal weergeven in de verleden tijd, zoals in het Frans, is daardoor in feite niet meer doenlijk. Alleen het nevenschikkend voegwoord ('en' / 'et') ontbreekt in beide talen; dát was een van de dingen die de eerste lezing wat stijf maakte. (Lees deze en de vorige twee zinnen nog eens over en realiseer je hoe veel keren de letter ' $\mathrm{e}$ ' in een Nederlandse zin optreedt.)

Toch is er een jaar of tien geleden een Nederlandse vertaling van La Disparition verschenen. ${ }^{10}$ Het bleek dus toch mogelijk! Nou ja, dat hangt wel af van hoe je de eis om een verhaal weer te geven 'zoals wij dat zouden zeggen / schrijven' interpreteert en of je het acceptabel vindt dat het in het hele boek, niet alleen in de dialogen maar ook in de reguliere verteltekst, wemelt van de 't-s en 'n-en. Stof tot nadenken en speculatie.

Wie overigens benieuwd is waar al die verloren gegane e's gebleven zijn, leze de navolgende geschiedenis getiteld Lees - en Beef! ${ }^{11}$ :

Een vreemde heerscher betreedt BERTHES erfdeel. Geen der edelen wederspreekt des wreeden WERNERS recht, het recht des sterksten. De vreemde heerscher, ten zetel der Wenden verheven, geeft het bevel: 'Breng BERTHE weg. Geen mensch helpe de zwervende: geen mensch geve der vernederde eten, dek en legerstede.' (Battus 1981: 31-32)

De bijbehorende opdracht luidt uiteraard: vertaal bovenstaande tekst naar het Duits, Engels, Italiaans, Russisch en Chinees. Het bontst wat betreft gekunstelde rederijkerij maakt Walter Abish het echter in zijn debuutroman Alphabetical Africa (1974: 1), waarvan hier de eerste alinea van het eerste hoofdstuk volgt.

Ages ago, Alex, Allen and Alva arrived at Antibes, and Alva allowing all, allowing anyone, against Ales's admonition, against Allen's angry assertion: another African

Georges Perec,'t Manco (2009). Dat de vertaler heeft gezien dat de achternaam van de hoofdpersoon verwijst naar de ontbrekende klinker (voyelle) moge blijken uit het feit dat hij hem in het Nederlands Anton Vocalis heeft genoemd. 
amusement... anyhow, as all argued, an awesome African army assembled and arduously advanced against an African anthill, assiduously annihilating ant after ant, and afterward, Alex astonishingly accuses Albert as also accepting Africa's antipodal ant annexation. Albert argumentatively answers at another apartment. Answers: ants are Ameisen. Ants are Ameisen?

Inderdaad, alle woorden in hoofdstuk 1 beginnen met een a. Hoofdstuk 2 vervolgens kent alleen woorden die òf met aan òf met een $b$ beginnen, hoofdstuk 3 alleen woorden die beginnen met een a, b of c, et cetera, totdat uiteindelijk in hoofdstuk 26 alle woorden van je taal beschikbaar zijn, waarna de auteur de zaak in de volgende hoofdstukken in omgekeerde volgorde afbouwt, zodat in hoofdstuk 52 weer alleen maar a-woorden voorkomen. Ik vrees dat hier geen creatief kruid tegen gewassen is en dat wij hier de grenzen van de vertaalbaarheid hebben bereikt.

Laat je door dit laatste ontmoedigende voorbeeld echter niet uit het veld slaan. Hopelijk hebben alle daarvoor behandelde gevallen van vormproblematiek aangetoond dat je met een flinke portie creatief vermogen (en wat geluk) vaak een heel eind kunt komen. Helaas vielen er maar weinig algemeen geldende recepten te geven, want haast elk van dit soort problemen is uniek.

Toch nog een laatste advies. Goed, je weet dat je, naarmate de vorm van een tekst(gedeelte) complexer en dwingender wordt, als vertaler steeds meer water bij de wijn moeten doen. Maar leg je niet te snel neer bij een dreigende deceptie en blijf zoeken en proberen. Des te groter het geluksgevoel wanneer je ineens de ultieme ingeving krijgt. 


\section{Bibliografie}

Abish, Walter. Alphabetical Africa. New York: New Directions Publishing, 1974.

Battus. Opperlandse taal- \& letterkunde. Amsterdam: Querido, 1981.

Bindervoet, Erik en Robbert-Jan Henkes. Help! The Beatles in het Nederlands. Amsterdam: Nijgh \& Van Ditmar, 2003.

Burgess, Anthony. A Clockwork Orange. London: William Heinemann, 1962.

Cairo, Edgar. Ik ga dood om jullie hoofd. Haarlem: In de Knipscheer, 1980.

Carroll, Lewis. Alice's Adventures in Wonderland. Londen: Macmillan, 1865.

Dylan, Bob. Liedteksten 1962-1973 en Liedteksten 1974-2001. Amsterdam: Nijgh \& Van Ditmar, 2016.

Dylan, Bob. Liedteksten 2002-2012. Amsterdam: Nijgh \& Van Ditmar, 2017.

Dylan, Bob. Tarantula. Amsterdam: Nijgh \& Van Ditmar, 2017. Vertaling Erik Bindervoet en Robbert-Jan Henkes.

French, Albert. Holly. London: Penguin Books, 1995.

French, Albert. Holly. Vertaald door Rien Verhoef. Amsterdam: Balans, 1996.

Hines, Barry. A Kestrel for a Knave. Londen: Penguin Books, 1968.

Lekens, Frank. Shakespeares sonnetten; interpretatie en vertaling. http://fmlekens.home.xs4all.nl/ Q1609/. Geraadpleegd 15 januari 2019.

Matsier, Nicolaas. Alice in Verbazië. Amsterdam: De Bezige Bij, 1996.

Milne, A.A. Winnie-the-Pooh. London: Methuen, 1926.

Mitchell, David. The Thousand Autumns of Jacob de Zoet. London: Sceptre, 2010. Vertaling: De niet verhoorde gebeden van Jacob de Zoet. Vert. door Harm Damsma en Niek Miedema. Amsterdam: Ailantus, 2010.

Moody, Rick. Purple America. New York: Little, Brown and Company, 1997.

Perec, Georges. La Disparition. Parijs: Gallimard, 1969. Vertaling: 't Manco. Vert. door Guido van der Wiel. Amsterdam: De Arbeiderspers, 2009.

Rot, Jan. Rot voor u. Hellevoetsluis: Stichting Okapi / Stichting Jan Rot, 2010.

Swan, Susan. The Wives of Bath. Toronto: Random House, 1993. Nederlandse vertaling: Genadeloze meisjes. Vert. door Inge de Jong. Amsterdam: Arena, 1996.

Swift, Graham. Wish You Were Here. London: Picador, 2011.

Welsh, Irvine. Trainspotting. London: Martin Secker \& Warburg, 1993. 



\title{
2.5. \\ De vertaling van meerstemmigheid en meertaligheid
}

\author{
Désirée Schyns
}

In een rondetafelgesprek tussen de Zuid-Afrikaanse vertaler-dichter Daniel Hugo en de Vlaamse schrijvers Stefan Hertmans en Tom Lanoye haalde Hugo een passage aan uit Oorlog en terpentijn waarin Hertmans West-Vlaamse woorden, archaïsch Nederlands en Frans laat mee resoneren. ${ }^{1}$ De vertaler in het Afrikaans had moeite met woorden als 'klapotter,' 'klepsjiezen' en 'kroelkesvolk' die de grootvader in de mond nam om een schilder als Ensor te omschrijven. Als strategie had hij ervoor gekozen sommige van die woorden uit de streektaal in het Vlaams te laten staan in zijn Afrikaanse tekst. ${ }^{2}$

Mikhail Bakhtin schreef dat een roman niet één stijl, maar een conglomeraat, een veelvoud aan literaire stijlen heeft. Door de aanwezigheid van de vertellersstem, de stilering van dagelijks taalgebruik en de individuele 'talen' van de personages, is elke roman meerstemmig, of polyfoon. De romantaal biedt een heterogeen systeem van talen en een diversiteit aan sociale taalvormen. De roman als genre kan, nog steeds volgens Bakhtin, niet zonder een dergelijke stratificatie van 'sociale dialecten' (Todorov 1984: 56-59). De kracht van de roman schuilt in de interactie van die verschillende 'talen'.

Het septembernummer 2018 van Filter was gewijd aan het vertalen van meertaligheid in romans. Een mogelijke definitie van meertaligheid is dat een brontekst meerdere talen in zich bergt (denk aan Oorlog en vrede dat naast het Russisch fragmenten in het Frans bevat) en/of dat de brontekst fragmenten in zich bergt

1 Het gesprek vond plaats op 26 oktober 2018 bij de Faculteit Letteren en Wijsbegeerte van de Universiteit Gent waar Daniel Hugo 'vertaler op de campus' was in het kader van de Leerstoel Zuid-Afrika: talen, literaturen, cultuur en maatschappij.

2 Zie hoofdstuk 2.4. 
die afwijken van de 'standaardtaal', zoals we net zagen bij Oorlog en terpentijn. Het afwijken van de standaardtaal uit zich in het gebruik van slang en argot, van regiolecten en sociolecten, in het gebruik van Spanglish, van Creools, van Arabische woorden in het Frans, van Xhosa in het Afrikaans, van Turks in het Duits, van historische variëteiten en de lijst kan nog langer worden. Literaire taalvariatie blijkt enorm gevarieerd en afhankelijk van de culturele inbedding van de tekst. En ook die inbedding is complex: is er sprake van interactie tussen een dominante koloniale taal en een autochtone door de (voormalige) kolonisator naar de periferie verdreven taal? Leeft de auteur in ballingschap en dialogeert hij met de vroegere (thuis)taal of landstaal, is de taalvariatie een gevolg van (gedwongen) migratie, van geslaagde integratie, van het naast elkaar bestaan van twee talen in de fictieve wereld die de roman beschrijft en die een weerspiegeling is van de werkelijkheid? Wat is eigenlijk de functie van de code-switching en hoe is de verhouding tussen moedertaal en vreemde taal? Wordt een vreemde taal ingezet als couleur locale, met andere woorden om de meertalige werkelijkheid na te bootsen? In wat volgt wil ik een paar voorbeelden bespreken, waarbij er sprake is van een verglijdende schaal: van meerstemmigheid naar meertaligheid naar het experiment met meerdere talen.

\section{Gradaties van meerstemmigheid}

Een voorbeeld van meerstemmigheid in bakhtiniaanse zin komt van de Italiaanse schrijfster Natalia Ginzburg. Familielexicon (1991) gaat over vertrouwde woordjes en uitdrukkingen waarmee de omgang in familiekring was doorspekt. Het is een autobiografisch boek en Ginzburg wil herinneringen ophalen aan mensen van vlees en bloed (zoals ze in de 'Waarschuwing' schrijft). Vertaalster J.H. Klinkert-Pötters Vos heeft manieren gevonden om recht te doen aan die vreemde manier van praten die in het gezin Ginzburg schering en inslag was. Bij het lezen van de Nederlandse tekst (die ik op zijn eigen merites beoordeel, als Nederlandse tekst, want ik lees geen Italiaans) krijg je een indruk van de verschillende stemmen. Je zou de wijze waarop de vader bijvoorbeeld bestaande woorden op een onverwachte manier inzet voor situaties waarin het woord meestal niet wordt gebruikt, een vorm van idiolect kunnen noemen. Het Nederlandse woord 'hufterig' bijvoorbeeld: "Zo was het ook hufterig om je hoofd met een sjaaltje of strohoed tegen de zon te beschermen of een regenkapje te dragen (...)” (Ginzburg 1991: 7). Het werkt komisch om te bedenken dat het asociaal, onbeschoft en ongemanierd zou zijn 
om een regenkapje op te zetten. De grootste uitdaging voor de vertaler is hier het zich inleven in het gebruikte register van de familieleden en het consequent om te zetten voor Nederlandstalige lezers zonder dat het al te veel van zijn (komische) eigenheid verliest.

Proust laat huishoudster Françoise in alle delen van $A$ la recherche $d u$ temps perdu (een geconstrueerd) dialect spreken. Daarnaast voert hij in $\grave{A}$ l'ombre des jeunes filles en fleurs ook een koeterwaals sprekende hoteldirecteur op, een argot sprekende Albertine, een geaffecteerde Odette, die hier en daar in het Frans een Engels woordje laat opklinken en een studentikoze Bloch. Ook de hoerenmadam heeft een heel eigen taalgebruik, net als de deftige, of deftig doende vriendinnen van mevrouw Swann, waardoor de tekst satirische elementen vertoont. Bij Proust zie je duidelijk de stilering van verschillende vormen van dagelijkse, mondelinge vertelvormen aan het werk. Proust ving de tijdsgeest en gaf sociale mobiliteit en sociale verhoudingen weer. Achter die heterogene stemmen zit een visie op de wereld en de werkelijkheid, ze moeten daarom hoe dan ook worden weergegeven, maar zoals Grutman ook al stelt, bijvoorbeeld bij het vertalen van dialect, moet je uitkijken dat je niet te veel van register verandert, zorg ervoor dat de lezer niet in een klucht belandt (Grutman 2018: 9). Je bereikt soms al heel wat door een piepkleine ingreep uit te voeren, zou ik eraan willen toevoegen. Het is zaak je als vertaler een beeld te vormen van al die personages en ze in je vertaling tot leven te wekken. Dat gebeurt bijvoorbeeld met verve in de vertaling van Du côté de chez Swann van Martin de Haan en Rokus Hofstede (Proust 2015) waarin de verschillende personages levendig en met hun eigen (afwijkende) taalgebruik op de voorgrond treden.

Een roman waarin meerstemmigheid én vooral meertaligheid een nog grotere rol spelen is Een verhaal van liefde en duisternis (2006) van Amos Oz. Het wemelt er van de stemmen die ik dankzij vertaalster Hilde Pach heb horen klinken (ik lees geen Hebreeuws). De (dichterlijke) vertellersstem, die van de vader, de grootouders, de tante, de echtgenote van de geleerde oudoom. Allemaal ballingen en vluchtelingen met een grote kennis van soms zeven (of meer) Europese talen. In de passages met metataal denkt de verteller na over Hebreeuwse woorden. De roman bevat Bijbelse taal en reflecteert over het verschil tussen Bijbels en modern Hebreeuws. In het Hebreeuws weerklinkt het Russisch van opa Alexander, soms spreekt de vader spottend in hoofse taal om zijn zoon gespeeld beleefd te plagen. Tot slot speelt $\mathrm{Oz}$ het generatieverschil uit tussen de ouderen die Hebreeuws nog uit de boeken hadden geleerd en het gebrekkig spraken en de jongere generatie waartoe de verteller (en $\mathrm{Oz}$ ) 
behoort. De jonge generatie sprak een taal die als spreektaal voor een deel opnieuw moest worden uitgevonden, het Ivriet, een woord dat Oz overigens niet gebruikt. Hierdoor ontstaan komische en hilarische misverstanden die ook in het Nederlands worden uitgedrukt. Dat ik al die zaken kan onderscheiden komt omdat de vertaalster accenten heeft aangebracht en de meerstemmigheid en meertaligheid die met de hele tekst zijn verweven recht heeft gedaan. Dat accenten in verschillende vertalingen anders gelegd worden ontdekte ik bij het lezen van de Franse vertaling waarin de talige generatiekloof (om slechts een voorbeeld te noemen) niet werd uitgespeeld.

Het verdriet van België van Hugo Claus is geschreven in poëtisch klassiek Nederlands afgewisseld met woordspelletjes en neologismen en is (in de dialogen) doorspekt met een geconstrueerd Vlaams boordevol archaïsmen, dialectismen en gallicismen. ${ }^{3}$ De roman is een groot vat van meerstemmigheid. In zijn voorwoord bij de Franse vertaling merkt Alain van Crugten (Van Crugten 1985: 9) op dat dit gebruik van gallicismen en Franse zinnen ironisch werkt omdat ze worden uitgesproken door een familie die in politiek en taalkundig opzicht sterk anti-Frans is en zich onderdrukt voelt door Franstalige Belgen. Voor zijn vertaling vermengde de Franstalige Belg het gangbare Frans van Frankrijk met Franstalig Belgische woorden en uitdrukkingen die voor Fransen even exotisch klinken als het 'Vlaams' in de oren van 'Hollanders'. Zijn normafwijkend taalgebruik in de doeltaal om het even normafwijkende (van de Noord-Nederlandse norm) taalgebruik van Claus weer te geven bleek bij de Parijse uitgeverij Julliard in eerste instantie op veel weerstand te stuiten: “(...) du rouge partout, des biffures, des corrections innombrables, les commentaires rageurs d'une correctrice: 'Ne se dit pas!!' 'Inexistant en français!!' Incorrect!!'” (geciteerd door Smeyers 2018: 119) maar Van Crugten zette door. Vertalers van hedendaagse Vlaamse auteurs (Griet Op de Beeck, Tom Lanoye, Lize Spit ...) zullen veel met dit fenomeen (de aanwezigheid van dialect en/of tussentaal naast het standaard Nederlands) te maken hebben. In het eerdergenoemde forumgesprek stelde vertaler Daniel Hugo, die zowel Nederlandse als Vlaamse auteurs vertaalt, dat het vertalen van Vlaamse auteurs moeilijker is door het veelvoud aan registers en de aanwezigheid van een volgens hem rijker Nederlands dat afwijkt van de norm. Auteurs Hertmans en Lanoye blijken weleens te moeten onderhandelen over het gebruik van hun Nederlands omdat redacteuren van boven de Moerdijk niet altijd begrijpen wat ze bedoelen. Hier speelt culturele hegemonie een belangrijke rol waarmee ook Vlaamse vertalers worden geconfronteerd (cf. Noble \& Schyns 2008). 


\section{De aanwezigheid van een andere taal naast de 'matrijstaal': historische documenten}

Ik ontleen het woord 'matrijstaal' aan Grutman (2018: 7), het is de tekst waarin het grootste deel van het werk geschreven werd. Met een andere schrijftaal erbij is in dit geval letterlijk sprake van meerdere talen in één en dezelfde tekst. In dergelijke gevallen spelen de normen van de doelcultuur een belangrijke rol. Waar het $\mathrm{Ne}$ derlands een grote tolerantie vertoont voor de aanwezigheid van bijvoorbeeld het Duits (in ieder geval in de jaren zestig), geldt dat in mindere mate voor bijvoorbeeld Frankrijk, waar de gemiddelde lezer geen langere fragmenten in het Duits kan begrijpen. Bij de twee voorbeelden van historische documenten die ik geef is de meertaligheid in vertaling dan ook bijna uitgewist. De wereld van de Joodse door de nazi's vermoorde dagboekschrijfster Etty Hillesum was meertalig. Zij woonde in Amsterdam, studeerde Russisch (haar moeder was van Russische afkomst) en sprak dagelijks Duits met de Duitse migranten die op de vlucht voor de nazi's in Amsterdam terecht waren gekomen. Duits was ook de taal waarin zij meestal las en in haar dagboek citeert ze voornamelijk uit het Duits. Zo speelt het Duits een grote rol in haar nagelaten geschriften. Uit het voorwoord van de vertalers (Noble \& Rosselin 2008: 26) blijkt dat zij de Duitse zinnen uit de brontekst in de Franse vertaling cursief zetten. De Duitse citaten en overpeinzingen van Etty Hillesum werden in het Frans vertaald, maar dankzij de paratekst heeft de Franstalige lezer toch weet van de aanwezigheid van de grote hoeveelheid Duits in de Nederlandse dagboeken.

Een ander voorbeeld is De zaak 40/61. Een reportage (1979) van Harry Mulisch. 40/61 verwijst naar het nummer van de zaak-Eichmann bij de arrondissementsrechtbank van Jeruzalem in 1961. Het is een reportage over dat beroemde proces die Mulisch eerst als een serie losse artikelen publiceerde in het weekblad Elsevier. Het boek dat hieruit ontstond is niet alleen een verslag maar ook een 'auto-reportage', een analyse van de schrijver van zijn pogingen te begrijpen wat zich in Eichmanns hoofd en dat van andere beulen moet hebben afgespeeld. In zijn inleiding bij de boekuitgave zegt Mulisch (wiens vader een Oostenrijker was die met de Duitse bezetter collaboreerde) dat hij de citaten in het Duits heeft laten staan en niet in het Nederlands heeft vertaald: "Citaten zijn zo veel mogelijk in het Duits, want in het Nederlands is het niet meer, wat het is: gevaarlijk. Voor wie geen Duits kent, is een der voornaamste toegangen tot De zaak 4o/61 gesloten - tot zijn geluk misschien” (Mulisch 1979: z.p.). In de Franse vertaling sneuvelden de Duitse citaten. Er is ook 
geen paratekst over de omgang met het Duits in vertaling. Dit heeft te maken met het feit dat Mireille Cohendy in 2003 een beginnend vertaalster was, zo vertelde zij tijdens een forumdiscussie over het vertalen van getuigenisliteratuur (Schyns 2018). Mocht zij nu voor de tekst van Mulisch gevraagd worden dan zou zij noten hebben toegevoegd en meer hebben uitgelegd, omdat het Duits in de ogen van Mulisch een van de belangrijkste toegangen tot de tekst betekent.

\section{Een multiculturele wereld (in een postkoloniale context)}

Veel vertalers zullen vandaag de dag de opdracht krijgen een roman te vertalen die zich afspeelt in een multiculturele wereld, of in een postkoloniale context, een wereld waarin de verhouding tot het koloniale verleden een rol speelt. De aanwezigheid van andere talige elementen in de brontaal (bijvoorbeeld verbonden met de Bengaalse cultuur in het Engels van Zadie Smith, cf. Jooken 2018), of het Arabisch in het Frans bij Kif Kif demain van Faïza Guène (zie Lievois, Kloots en Nahed 2018), is niet louter mimetisch, dus bedoeld om de werkelijkheid te imiteren. De taalvariatie weerspiegelt (in bakhtiniaanse zin) bijvoorbeeld ook sociale verschillen tussen personages en kan verbonden zijn met krachtige emoties en/of satire. Bij het vertalen van dergelijke meerlagige en complexe romans zullen vertalers vaak tegen de grenzen van hun eigen taal en cultuur botsen, althans zo verging het mij: bij het vertalen van de romans van de Frans-Algerijnse Malika Mokeddem die haar Frans inzet als 'butin de guerre' (oorlogsbuit, een taal die in 183 o bij de kolonisatie van Algerije door de autochtone bevolking op de Fransen werd buitgemaakt), stuitte ik op mijn onvermogen om een equivalent te vinden voor het contesterende en afwijkende Frans dat een lange neus maakt naar de voormalige Franse kolonisator. In het Nederlands kan de verhouding tot het koloniale verleden nu eenmaal niet op dezelfde manier doorklinken (Schyns 2014). Bovendien stuitte ik op taalkundig onvermogen doordat ik geen Arabisch ken, terwijl het Arabisch bij Mokeddem en een aantal andere Franstalige auteurs uit de Maghreb een soort onderliggend tekstweefsel is, dat moeilijk te duiden valt voor mensen die geen Arabisch kennen. Dat neemt niet weg dat je als vertaler mogelijkheden hebt wanneer je met dergelijke (inspirerende) teksten aan de slag gaat. Misschien is het besef belangrijk dat je niet altijd alles kunt honoreren. En misschien kunnen workshops over het vertalen (uit het Engels, of Frans) van dergelijke teksten soelaas bieden? 


\section{Het reflecteren over meertaligheid: Yoko Tawada}

In haar bijdrage voor het themanummer van Filter stelt Ilse Logie dat het nog steeds "overwegend eentaligheid is die de wereld en de artistieke representatie ervan vormgeeft" (Logie 2018: 57). Wel is het zo dat meertaligheid in de hedendaagse literatuur sterk in opmars is en de eentaligheid die het Westerse denken nog steeds domineert onder druk zet. Daarmee geeft Logie aandacht aan avant-gardistische en experimentele teksten die een vrijplaats vormen waar die eentalige hegemonie wordt overstegen. Daarom wil ik tot slot een voorbeeld geven van een experimentele tekst waarin gespeeld wordt met en gereflecteerd wordt over meertaligheid en zelfs gefingeerde talen ingelast worden, als een vorm van verzet tegen het heersende monolinguale paradigma. Ik vraag me af of vertalers veel van dergelijke opdrachten krijgen, uitgevers staan huiverig tegenover experimentele teksten in een andere taal omdat ze (terecht) vrezen niet genoeg lezers te bereiken wanneer dergelijke teksten vertaald worden. Het zijn vooral niche-uitgevers die zulke avonturen aangaan. Door haar teksten te situeren op geografische plekken waar meerdere culturen met elkaar botsen, in een unieke constellatie samenkomen en met elkaar in relatie worden gebracht, schept de Japans-Duitse Yoko Tawada taalbotsingen waaruit verrijkende, nieuwe inzichten, ongewone poëtische woorden en flitsende beelden ontstaan. Tawada is zelf een geëmigreerde auteur (zij verhuisde van Japan naar Duitsland) en publiceert in het Duits (haar tweede taal) en Japans (haar moedertaal). Zij muntte de term 'exofonie' om schrijvers aan te duiden die niet in hun moedertaal schrijven. Tawada wil niet worden gereduceerd tot één land van herkomst en probeert ook niet de 'typische Japanse blik' te ensceneren waarmee mensen haar maar al te graag opzadelen. In een van haar teksten uit Überseezungen (2002), 'Bioscoop van de nacht', schept zij een gefingeerde taal. De personages in het verhaal, dat zich afspeelt in Zuid-Afrika, spreken een in het Duits vertaald Afrikaans, waardoor de vertalers voor grote problemen stonden. Zo begint het verhaal in een winkel waarin een man zichzelf aanduidt als 'die Mann', waarbij een lidwoord in het Afrikaans gecombineerd wordt met het Duitse woord Mann. Het vervreemdende, transseksuele aspect moest behouden blijven in het Nederlands en om die reden is er niet gekozen voor 'die man' maar voor 'die mannin' (Brandt \& Schyns 2010: 147). 


\section{Tot besluit}

In het voorafgaande heb ik een aantal voorbeelden besproken van de mogelijke omgang met verschillende vormen van het fenomeen meerstemmigheid en meertaligheid, waarbij ik wilde aantonen dat er gradaties van meerstemmigheid bestaan en ook gradaties in het weergeven ervan. Soms kiezen vertalers voor een combinatie van strategieën, of behouden zij de meerstemmigheid, maar dan minder intens. Laten we voor ogen houden dat polyfonie, net als cultureel specifieke elementen, geen geïsoleerd fenomeen is, maar verweven met het persoonlijke project van auteurs, met hun geschiedenis en culturele zoektocht, met de dialoog met hun lezers op wie zij zich oriënteren en die hun romandiscours kleurt (Todorov 1984: 62). Soms is een vreemde taal alleen in het onderliggende tekstweefsel aanwezig en word je als vertaler niet direct met een vertaalprobleem geconfronteerd, omdat je het culturele substraat niet herkent. Wel is het dan van belang je bewust te zijn dat er nog een andere taal onderhuids mee resoneert. Vaak heeft de polyfonie zich overal genesteld en gaat het niet om een paar losse zinnen. Zaken die volgens mij van belang zijn, zijn de functie van de polyfonie, de relatie tot de context, de normen van de doelcultuur, de taalkundige beperkingen die grenzen stellen aan vertaalbaarheid en de rol van de uitgever. Vertalers zullen zich dus in eerste instantie scherp bewust moeten zijn van het taalgebruik waaraan de roman zijn kracht ontleent en de (onderliggende) meerstemmigheid in kaart moeten brengen. Veel secundaire literatuur lezen helpt, workshops volgen en vertaalproblemen met anderen bespreken lijken me onontbeerlijk. 


\section{Bibliografie}

Brandt, Bettina en Désirée Schyns. "Het bestaan van een heel andere taal voelbaar maken.” Yoko Tawada, De Berghollander. Samenstelling, vertaling en nawoord door Bettina Brandt en Désirée Schyns. Amsterdam: Voetnoot, 2010, p. 141-152.

Ginzburg, Natalia. Familielexicon. Vertaald uit het Italiaans door J.H. Klinkert-Pötters Vos. Amsterdam: Meulenhoff. 1991/1988.

Grutman, Rainier. “Ingelaste talen vertalen: vier literaire scenario's." Filter 25:3 (2018), p. 5-13.

Jooken, Lieve. "Witte tanden en kissing teeth. De vertaling van verbale en niet-verbale codes in meertalige literatuur." Filter 25:3 (2018), p. 13-25.

Lievois, Katrien, Kloots Hanne, Nahed, Noureddine. "Kif- kif? Arabische ontleningen in de Nederlandse, Spaanse en Arabische versie van Kiffe kiffe demain." Filter 25:3 (2018), p. 37-49.

Logie, Ilse. "Meertaligheid als paradox. Twee hedendaagse interculturele autobiografieën." Filter 25:3 (2018), p. 55-63.

Mulisch, Harry. De zaak 4o/61. Een reportage. Amsterdam: De Bezige Bij, 1979/1961.

Noble, Philippe en Isabelle Rosselin. “Avertissement des traducteurs." Les écrits d'Etty Hillesum. Journaux et lettres 1941-1943, édition intégrale, traduit du néerlandais et de l’allemand par Philippe Noble avec la collaboration d'Isabelle Rosselin. Paris: Seuil. 2008 p. 25-28.

Noble, Philippe en Désirée Schyns. "Neerlandofonie: pleidooi voor een transnationale en transcontinentale taal." Ons Erfdeel 51:5 (2008), p. 98-107.

$\mathrm{Oz}$, Amos. Een verhaal van liefde en duisternis. Vertaald uit het Hebreeuws door Hilde Pach. Amsterdam: De Bezige Bij, 2006.

$\mathrm{Oz}$, Amos. Une histoire d'amour et de ténèbres. Traduit de l'hébreu par Sylvie Cohen. Paris: Gallimard, 2004.

Proust, Marcel. Swanns kant op. Vertaald uit het Frans en van een nawoord voorzien door Martin de Haan en Rokus Hofstede. Amsterdam: Atheneum Polak \& Van Gennep, 2015.

Schyns, Désirée. "Een verhouding van spanning en integratie. Literaire meertaligheid in vertaling." Filter 21:3 (2014), p. 50-63.

Schyns, Désirée. "Een schild van liefde. Gesprek met David Bellos, Daniel Cunin, Mireille Cohendy, Marianne Kaas en Philippe Noble.” Webfilter, dossier Getuigenis in vertaling 2018, https:// tijdschrift-filter.nl/webfilter/dossier.aspx. Geraadpleegd 15 januari 2019.

Smeyers, Elies. “De totstandkoming van Hugo Claus' werken in het Frans.” In Jaap Grave en Lut Missinne (red.) Tussen twee stoelen, tussen twee vuren. De Nederlandse literatuur op weg naar de buitenlandse lezer, LLS 10, Gent: Academia Press. 2018, p. 109-129.

Tawada, Yoko. Überseezungen. Tübingen: Konkursbuch Verlag, 2002.

Todorov, Tzvetan. Mikhail Bakhtin. The dialogical principle, translated by Wlad Godzich. Manchester: University Press, 1984.

Van Crugten, Alain. "Avant-propos du traducteur." Hugo Claus, Le chagrin des Belges, traduit du néerlandais par Alain van Crugten. Paris: Julliard, 1985, p 7-10. 



\section{6. \\ Humor}

Jeroen Vandaele

Humor is een complex gegeven en vaak een struikelblok voor vertalers (Chiaro 2005; Bellos 2011: 284). In dat opzicht is humor zoals literatuur. Wie humor in literatuur vertaalt, moet dus van vele markten thuis zijn.

\section{Wat is humor? Wat is literaire humor?}

Humor is volgens Van Dale "dat wat grappig, geestig, om te lachen is". Wie humor heeft, heeft "oog en gevoel voor vrolijkmakende tegenstrijdigheden tussen voorkomen en bedoeling of betekenis van zaken" of, actiever, "de neiging het vrolijkmakende in gebeurtenissen het meest te doen uitkomen” (ibid.). Maar we kunnen humor ook technischer beschrijven. Enerzijds verwijst humor naar een universele emotie met een aangename en vaak sterk veruitwendigde lichamelijke component - een vrolijk gevoel, een geamuseerd-zijn, een glimlach, een lach, een schaterlach, een bulderlach. Haast iedereen heeft een bepaald gevoel voor humor, een zekere neiging om vrolijk te worden en te lachen ten gevolge van gepercipieerde incongruenties, d.w.z. ten gevolge van zaken die niet lopen zoals te verwachten viel maar die toch op een onverwachte, speelse, soms absurd vergezochte manier begrijpelijk zijn. Dit is de visie op humor van de zogenaamde Incongruity Theories (cf. Vandaele 2002a; Carroll 2014). Wie kan lachen om bepaalde humor, krijgt een positief gevoel, en de sociale cohesie van een groep kan versterken wanneer leden - hier minstens auteur en lezer - zich eventueel samen met andere groepsleden oprecht vrolijk maken om iets. Men voelt zich op een aangename manier normatief congruent, een deel van de insiders, de begrijpende klasse. Ironie, die een komisch effect kan hebben, leunt hier vaak sterk bij aan (Booth 1974: 44). 
Anderzijds benadrukken de zogenaamde Superiority Theories de keerzijde van de medaille (Gruner 1997; Vandaele 2012: 61-62). Als een toehoorder kan lachen om de humor van een humorist, dan kan een derde zich juist níet aangesproken voelen, of uitgelachen, of simpelweg uitgesloten door een gebrek aan vooronderstelde kennis. Er heersen en circuleren verschillende opinies, smaken, gevoeligheden over wie of wat mag worden bespot of uitgesloten of incongruent beschouwd in deze of gene of eender welke context. Humorperceptie en -appreciatie variëren sterk volgens persoon en groep en tijdperk.

Wat literaire humor betreft, is het belangrijk te begrijpen dat de verhouding tussen humorist, lacher en mogelijke derden zich in dynamisch wisselende constellaties kan enten op verschillende actoren van de literaire communicatie: de auteur van vlees en bloed, de ik-persona van een gedicht (die vaak innig verbonden is met de auteur), de impliciete auteur (of auteur zoals die naar voren lijkt te komen uit een tekst), de verteller of vertellers, de personages, de lezer of toeschouwer, en velerlei derden (referenten waar de lezer of toeschouwer aan denkt, op aansturen van de tekst en door vrije analogie of associatie). Deze dynamisch wisselende constellaties van literaire humor treden in complexe interactie met andere emoties in de literatuur, specifiek de empathie, waar humor nu eens haaks op staat en dan weer toe bijdraagt. Soms zal een auteur een komisch incongruente verteller creëren, soms zal een verteller zich ironisch boven de fratsen van personages stellen, soms zal de verteller zichzelf als verteller of personage komisch relativeren (cf. Wood 2005; Vandaele 2010: 743-77). De vertaler van humor in de literatuur dient vertrouwd te zijn met literaire meerstemmigheid ${ }^{1}$ - omdat komische en ironische effecten er zich bij uitstek op enten en toe bijdragen.

De diversiteit aan komische en ironische interacties tussen vaak erg verschillende stemmen is een eerste algemeen probleem voor vertalers van literaire humor. Een tweede globaal probleem is de grote zichtbaarheid en herkenbaarheid van de emotie die door humor wordt opgeroepen, wat de komische kwaliteit van de vertaling bijzonder toetsbaar maakt, en de vertaler dus erg kwetsbaar: you know humor when you feel humor (zie Vandaele 2002b). De specifieke problemen die hieronder worden beschreven, staan nooit los van deze twee algemene moeilijkheden.

1 Zie hoofdstuk 2.5. 


\section{Detectieproblemen}

\section{Vooronderstelde kennis}

"Humor uit andere tijden of culturen valt moeilijk op te merken", schrijft Tymoczko (1999: 203-4). Een vertaler is daarom genoodzaakt kennis en sensitiviteit te hebben op het vlak van realia in de broncultuur, de in zwang zijnde praxis van het sociale leven, en bestaande discourstypes (om bijvoorbeeld een parodie als parodie te kunnen lezen). Maar aangezien kennis nooit volmaakt is, zal een vertaler idealiter ook humor leren vermoeden en vervolgens dat voorwerp van vermoeden aan kenners voorleggen. Wanneer ook maar één kennisschakel ontbreekt, treedt in de interpretatie van een tekst mogelijk een enorme frame-verandering op - van humor naar ernst, of van satire naar banaliteit of gebazel (Goffman 1974).

\section{Ironische stijl, wisselend register}

Volgens een gangbare definitie is ironie iets zeggen of schrijven en eigenlijk het tegenovergestelde bedoelen, maar volgens experten betreft het een complexer fenomeen. Linda Hutcheon (1994) bijvoorbeeld karakteriseert ironie breed als evaluatieve communicatie waarbij een scala van uitgesproken en onuitgesproken betekenissen in interactie kunnen treden. Mogelijke signalen van ironie zijn vaak elusief, zeker in literatuur - in die mate dat je je kunt afvragen of ironie überhaupt met onmiskenbare signalen werkt (Fish 1983). Toch is het voor vertalers van belang om gevoelig te blijven voor alle elementen die signalen kunnen zijn van een auteur, verteller of personage (zie Booth 1974: 47-86; Schoentjes 2001: 158-183; Lievois \& Schoentjes 2010).

Met name herhaling - met of zonder variatie - is een techniek die vaak ironisch of humoristisch werkt (Vandaele 2012: 69-75) maar door vertalers soms niet wordt opgepikt. Een gepubliceerde Spaanse vertaling deed bijvoorbeeld niets met het satirisch-parodiërende woordje 'so' ('dus ja', 'weet je wel') dat de zelfvoldane college girl Tiffany kenschetst in een ironisch-komische scene van Jonathan Franzens The Corrections (2001). Tiffany en vriendin Cheryl staan net als protagonist Chip op de luchthaven van het onrustige Vilnius:

\footnotetext{
"Do you have tickets?" Chip asked.

"For tomorrow," Tiffany said. "But things looked kinda nasty, so."

"Is this line moving?"
} 
"I don't know. We've only been here ten minutes."

"It hasn't moved in ten minutes?"

"There's only one person at the counter," Tiffany said. "But it's not like there's some other, better Finnair counter someplace else, so.” (2001: 525)

De herhaling van so lijkt een detail maar is van belang in de ironische karakterisering van Tiffany door Franzens vertelinstantie. Aangezien een herhalende vertaling perfect binnen de mogelijkheden van het Spaans ligt (asíque; sabes; o sea), heeft de vertaler het ironische mechanisme mogelijk niet opgemerkt.

Evenmin opvallend zijn lichte registerveranderingen met komisch effect. "Van een vreemde taal leren we het laatst de precieze waarde van woorden. Is dit nu alledaagse of verheven taal? Is dit sterk uitgedrukt of beledigend?" schrijft Del Corral (1988: 26-27), en ze voegt eraan toe dat komische romans vaak meer op uiterst precieze formulering bouwen dan op plot. ${ }^{2}$ In een beroemde scène van Javier Marías' klassieker Corazón tan blanco (1992, Een hart zo blank) geeft de Spaanse verteller, een sluikse en verveelde tolk, een reeks potsierlijke en banale wendingen aan een gesprek tussen twee staatshoofden voor wie hij tolkt - wellicht Margaret Thatcher en Felipe González, die hij respectievelijk 'la adalid británica' en 'nuestro adalid' noemt (68). Adalid is in de kolderieke context een grappig want al te plechtstatig woord (Santana López 2006: 307), maar de Nederlandse vertaling koos voor het vlakkere 'leider' (1993: 64) in plaats van bijvoorbeeld 'staatsvrouw' en 'staatsman', of 'bewindsvrouw' en 'bewindsman' - wat opnieuw op een detectieprobleem lijkt te wijzen.

Onderschatting loert steeds om de hoek. Zeker komische passages en boeken worden makkelijk onderschat, ook al zijn veel literaire klassiekers doordrongen van humor. Wat vertalers niet helpt, is dat ze vaak erg vroege lezers zijn van een werk dat pas later klassiek wordt. In een jachtige commerciële wereld zal een vroege vertaling van een toekomstige klassieker de stijl - zeker ook de komische stijl - mogelijk onderschatten.

\section{Andere 'humorblindheid': volgorde, visualisatie, smaak}

Andere vormen van humorblindheid zijn ook relevant voor vertaling. Ten eerste zien lezers - ook vertalers - soms niet wanneer de woorden van de brontekst enkel

2 Zie ook de volgende paragraaf. 
in een precieze volgorde hun effect krijgen (cf. Fish 1980), zeker wanneer de syntaxis van de doeltaal bovendien op een andere precieze volgorde aanstuurt. Wanneer Manolito Gafotas, het achtjarige komische personage gecreëerd door Elvira Lindo, vertelt dat hij met zijn vriendjes een gevaarlijk spel speelt - zo lang mogelijk op de weg liggen tot er een auto komt - dan steekt er wat verderop donkere humor in de keuze én de plaatsing van het laatste woord, een soort van punchline-woord: "De repente, vimos que se acercaba sin piedad un autocar" (1994: 88; letterlijk 'Plots zagen we dat er naderde, onverbiddelijk, een autocar'). Het Nederlands kan vertalers weliswaar influisteren om autocar naar voren te brengen ('Plots zagen we een autocar onverbiddelijk naderen'), maar een subtiel punchline-effect gaat zo verloren.

Humorblindheid houdt ten tweede ongetwijfeld ook verband met het bestudeerde continuüm tussen 'sterk visualiserende' en 'minder of weinig visualiserende' personen (high-low visualizer; Marks 1973). Wanneer literaire passages, boeken en oeuvres bijzonder sterk zijn in 'verbaal visuele' humor, d.w.z. wanneer ze dolkomische taferelen werkelijk voor het geestesoog schilderen, dan lijkt het wenselijk dat de vertaler ervan niet enkel een high verbaliser is, kenner van woordkeus en -volgorde, maar tevens een high visualiser (cf. Vandaele 2015). De humor van Elvira Lindo en Javier Marías, maar bijvoorbeeld ook van Cervantes, heeft vaak een sterk visuele component en heeft ongetwijfeld baat bij vertaling door een high visualizer.

Een laatste vorm van humorblindheid wordt gesuggereerd door Parks (2017), die vaststelt dat alom geprezen klassiekers bij hem vaak geen snaar raken - een herkenbare kwestie van smaak en voorkeuren. Dit besef van subjectiviteit is uiteraard ook pertinent voor vertaling van literaire humor. Een uitstekend vertaler die leest dat een klassiek werk vol humor steekt, maar er zelf nauwelijks om kan lachen, is wellicht niet de meest geschikte vertaler voor dat werk. Men spreekt onder vertalers weleens van een mismatch tussen werk en vertaler; het subjectieve karakter van literaire humor kan zeker een oorzaak zijn van zo'n mismatch.

\section{Omzettingsproblemen}

Vooropgesteld dat de vertaler er grotendeels in slaagt om de humor van een literaire tekst te detecteren, komt zij of hij vervolgens voor een complex probleem van omzetting te staan. Hieronder licht ik enkele specifieke aspecten van dit complexe probleem kort toe. 


\section{Functioneel impliciete kennis}

Zoals detectie een diepgaande kennis van de originele context veronderstelt, zo veronderstelt omzetting een accurate inschatting van kennis die het doelpubliek kan activeren. Bovendien zullen vertalers beseffen dat hun lezers grotendeels niet over die kennis beschikken, én dat ze deze kennis idealiter niet expliciteren omdat precies het impliciete karakter van de kennis medeoorzaak is van de humor (cf. Superiority Theories en het plezier van de insider). Ten slotte moeten vertalers beoordelen of potentiële oplossingen plausibel overkomen als weergave van de brontekst in kwestie: zullen hun Nederlandstalige lezers aannemen dat de gekozen oplossing een weergave is van een komisch gegeven uit een buitenlandse tekst?

Zulke problemen stellen zich vaak voor literaire parodieën. Raymond Queneau's Exercices de style (1947) is bijvoorbeeld voornamelijk amusant voor lezers die de schrijfstijlen herkennen waar Queneau mee speelt. Een vertaler kan weliswaar zelf een geparodieerde stijl kennen en herkennen, maar tegelijk vermoeden dat het doelpubliek van de vertaling mogelijk minder kennis of voeling heeft met het discours in kwestie. De vertaler kan in dat geval eventueel terugvallen op creatieve komische analogieën maar moet ook inschatten of deze analogieën door het doelpubliek nog aanvaard zullen worden als vertalingen van een specifieke literaire stem (auteur, impliciet auteur, persona, verteller, personage). Een vertaler die zelf een bekend auteur is, kan zich wellicht makkelijker enige vrijheid veroorloven, en zich mogelijk zelfs opstellen als (co)auteur door vertaling (cf. Refsum 2017).

\section{Woordspeling en co}

Het concept 'woordspeling' is moeilijk precies en omvattend te definiëren maar heeft minstens twee kernprincipes: (i) van één taalvorm - of van meerdere (bijna-) identieke taalvormen - worden (bijna-)simultaan verschillende betekenissen geactiveerd (Delabastita 2004: 601); en (ii) deze betekenissen worden als erg verschillend ervaren in de betreffende context. De titel van David Lodges boek Deaf Sentence (2008) - een 'grappige en ontroerende' roman 'over een man die leert omgaan met doofheid en de dood' (achterflaptekst, mijn vertaling) - is een 
woordspeling omdat hij verschillende betekenissen activeert ('dood'/'doof') die vastkleven aan meerdere bijna identieke (paronieme) taalvormen: deaf en death. Woordspelingen spelen dus met het gegeven dat in een welbepaalde taal $t$ verschillende betekenissen grotendeels willekeurig - vanuit het standpunt van andere talen - aan een taalvorm vastkleven, of aan taalvormen die vormelijke identiek of quasi-identiek zijn (death, deaf). Woordspelingen kunnen zich op velerlei taalaspecten enten - gelijkaardige uitspraak of schrijfwijze, polysemie, syntactische meerduidigheid, letterlijke interpretatie van figuurlijke taal - en verschillende talen hebben een verschillend potentieel op elk vlak (Delabastita 2004: 602-603). Bovendien is er een belangrijk contingent schrijvers -Shakespeare bijvoorbeeld (Delabastita 2002) - dat meertalige woordspelingen gebruikt. Woordspelingen zijn niet per definitie maar wel vaak grappig of minstens licht amusant, zoals de titel Deaf Sentence. Ze vormen namelijk een 'incongruent' taalgebruik omdat ze de intrinsieke meerduidigheid van taalvormen opzoeken en blootleggen (terwijl courant taalgebruik deze meerduidigheid veelal wenst weg te werken); en omdat woordspelingen eveneens de superioriteitsdynamiek van humor aanspreken (Delabastita 2004; 2005; Vandaele 2002a).

Woordspelingen vertalen is moeilijk omdat ze niet enkel een 'referentiële' functie hebben maar tegelijk 'zelf-referentieel' of 'meta-talig' zijn: ze verwijzen niet enkel naar zaken maar belichten bovendien iets wat eigen is aan taal $t$ zelf, met name de taaleigen vorm-betekenisdistributies van taal $t$ die grotendeels irrelevant zijn en onopgemerkt blijven in referentieel taalgebruik. Verwantschap tussen bron- en doeltaal kan occasioneel vertalersgeluk opleveren (Delabastita 2004: 603-604). Zo is 'De doofstraf' een voor de hand liggende vertaling van Deaf Sentence - al is er nog geen Nederlandse vertaling van het boek verschenen. Maar in Romaanse talen vergt Lodges titelkeuze al wat meer vertaalcreativiteit. De Franse vertaling (2009) koos voor La vie en sourdine, een vertaling die de slapende betekenis van stamwoord sourd ('doof') wakker maakt in de uitdrukking en sourdine ('gedempt, zachtjes'). Landheer (1989: 41) schat dat zo'n tachtig à negentig procent van de literaire woordspelingen een goeie vertaling kunnen krijgen. Delabastita (1993: 183-86) raadt vertalers aan om te focussen op de tekstfuncties van de woordspeling, zonder zich blind te staren op alle vormelijke details (zie ook Bellos 2011: 290; Norberg 2011: 222-27). Wel is het zo dat prestigieuze auteurs vrije vertaling vaak risicovoller maken voor de vertaler, tenzij deze zelf reeds een gerenommeerd auteur is. 


\section{Lecten, bestaand en fictief}

Vorm en inhoud zijn eveneens verstrengeld in humor met 'lecten', d.w.z. taalvariëteiten gebonden aan een sociale groep (sociolect), streek (dialect) of persoon (idiolect, zoals dat van een publiek figuur of een auteur, verteller of personage). ${ }^{3}$ Dit zijn taalvormen die identiteitskenmerken oproepen bij wie vertrouwd is met de taalvariëteit in kwestie. Aangezien humor bij uitstek drijft op een dynamiek van insiders (cohesie, herkenning) en outsiders (uitsluiting, spot), hoeft het niet te verbazen dat humoristen vaak de bindende en typerende krachten van taalvariëteiten aanwenden. Deze krachten zijn moeilijk vertaalbaar want per definitie lokaal, vaak stereotyperend (zeker in humor), en onzeker wat betreft analogieën uit andere streken.

Hoe radicaler een werk lecten bezigt voor komische doeleinden, hoe groter uiteraard het vertaalprobleem. Zo is Lindo's Manolito-reeks - met miljoenen verkochte exemplaren in Spanje - in belangrijke mate grappig en succesvol dankzij de herkenbare, goed getypeerde volkse Madrileense straattaal van verteller en personages. Herkenbaarheid is een van de 'konstanten van de komedie' (van den Bergh 1972), en dus lijkt de speakability of (op)zegbaarheid van de vertelstem en de dialogen een belangrijk aandachtspunt voor vertalers - net zoals op toneel of bij bepaalde komisch-ironische romanpassages in vrije indirecte rede (Vandaele 2010: 765-73). Wanneer zegbaarheid, opzegbaarheid en authenticiteit hoofdtroeven zijn van het origineel, dan staat de vertaler voor een zware opdracht.

Voorts dient gezegd dat komische en ironische schrijvers voor hun vertellers en personages inderdaad vaak idiolecten - persoonlijke vormen van taalgebruik - creëren die de grammatica en soms ook personages geweld aandoen. Wanneer Raymond Chandlers verteller in Lady in the Lake (1939) schrijft dat "Anna Halsey was about two hundred and forty pounds of middle-aged (...) woman" (geciteerd in Antonopoulou 2002: 208), dan bedoelt hij niet 'Anna Halsey was een vrouw van middelbare leeftijd die zowat 110 kilo woog' maar wel degelijk 'Anna Halsey was zowat 110 kilogram vrouw van middelbare leeftijd'. Chandler laat zijn verteller de constructie $X$ kilo of $Y$-waarbij $Y$ conventioneel een amorfe massa is - toepassen op een vrouwelijk personage. Dit is geen woordspeling maar toch een spel met woorden, want een vlakke parafrase zal het komische effect zeker tenietdoen (Antonopoulou \& Nikiforidou 2009: 297). Vertalers komt het dan toe het stilistisch vernuftige humormechanisme te zien, maar ook de emotionele lading ervan - hier erg krenkend - aan te voelen.

3 Zie ook 2.5. 


\section{Normverschillen: censuur, tact en agency}

De beschrijving van Anna Halsey maakt duidelijk hoe scherp - spits én kwetsend humor kan zijn. Literaire vertalers zijn steeds onderhandelaars of bemiddelaars tussen brontekst en doelcultuur, maar zeker inzake humor heeft elke cultuur haar eigen specifieke grenzen en taboes. Humor wordt daarom wel vaker gecensureerd - ook door middel van vertaling. Autoritaire regimes kunnen een vertaling weigeren, eigen correctoren inschakelen of vertalers zelf tot censuur verplichten; maar ook de 'vrije' markt van democratische landen kan censurerend werken. Wat voor velen censuur is, zal volgens de vertaler of uitgeverij wellicht tact zijn - een aanpassing aan eigen en geanticipeerde gevoelens van een lezersgroep. Censuur van literatuur wordt wellicht minder toegepast door wie aan auteurs van fictie een bijzondere maatschappelijke vrijheid toekent, wie fictieve personages (zoals Anna Halsey of Manolito) inschrijft in die context, en wie vertrouwen heeft in het beoordelingsvermogen van de lezer. Een gedurfde vertaling in een beknottende context kan in die zin juist een vorm van agency zijn.

\section{Archaïsche taal in oude bronteksten}

Zoals gezegd zijn veel klassieke werken deels of zelfs grotendeels komisch van opzet. Oudere komische teksten of passages - bijvoorbeeld de Quijote of delen van Moby Dick ${ }^{4}$ - stellen op zijn minst twee bijzondere problemen voor vertalers. Ten eerste kan een archaïserende vertaling de humor als het ware ondersneeuwen. Ishmael, de verteller van Melvilles Moby Dick (1851), heeft een bijzonder idiolect en is voor ons meer algemeen ook een oudere stem, met name uit de negentiende eeuw. In de vertaling van S. Westerdijk (1979) krijgt Ishmael een archaïsche stem, waardoor hij inderdaad klinkt als een stem uit het verleden, maar dat effect duwt de ingenieuze komische kwaliteit van deze vertelstem geregeld weg. Wanneer bijvoorbeeld de dolle, onstuimige Kapitein Peleg aan ‘jongeman’ Ishmael vraagt of ie echt wel wil gaan walvisjagen, als ie even bedenkt dat een walvis het been van Kapitein Ahab 'verslond, oppeuzelde en vermaalde', dan vervolgt verteller Ishmael: "I was a little alarmed by his energy" (2003: 80). De humor van dit nonchalant eufemisme raakt ondergesneeuwd door de ouwerwetse taal van Westerdijks Ishmael: "Ik raakte een weinig verontrust door de nadruk zijner woorden" (92).

$4 \quad$ Zie ook 1.6. 
Een tweede probleem doet zich voor wanneer oudere teksten voor komische doeleinden een beroep doen op taalgebruik dat toen reeds archaïsch overkwam. Zo citeert Melvilles Ishmael soms incongruent-archaïsch taalgebruik (hier van Kapitein Bildad) om het in scherp contrast te stellen met een eigen informele verteltrant.

"Dost thee?" said Bildad, in a hollow tone, and turning round to me.

"I dost," said I unconsciously, he was so intense a Quaker. (2003 [1851]: 84)
"Wenst gij zulks?" vroeg Bildad op holle toon, en keerde zich naar mij toe. "Zulks wens ik," sprak ik onbewust deze Kwaker in hart en nieren na. (1979: 96)

Weliswaar zijn de Nederlandstalige citaten ook archaïsch in Westerdijks Nederlandstalige versie, maar ze missen toch komische kracht omdat Ishmaels vertelstijl eromheen níet casual is. Dit gebrek aan contrast illustreert bij uitstek verlies van komisch meerstemmigheid in vertaling.

\section{Conclusie}

De vertaling van humor vergt zowel voeling met de humor van het originele werk als een productief gevoel voor humor gericht op een doelpubliek. Voeling en gevoel sluiten kennis en inzicht uiteraard niet uit. Voeling met de originele humor vooronderstelt een goed begrip van de originele tekst en context; en ook virtuoze vertalers zijn gebaat bij een goed inzicht in humormechanismen - om het origineel en de mogelijke vertaaloplossingen analytisch tegen elkaar af te wegen. Bij analyse zal de opdracht mogelijk nog moeilijker lijken dan voorheen, maar vaak wordt een schier onmogelijke vertaalopdracht haalbaar - en blijkt de oplossing geslaagd - wanneer men de utopie van volledige analogie of vergelijkbaarheid laat varen, en kiest voor een verdedigbare vergelijkbaarheid, ingegeven door een overwogen globale strategie gericht op de functie of rol van de humor in de meerstemmige literaire tekst. 


\section{Bibliografie}

Antonopoulou, Eleni. "A Cognitive Approach to Literary Humour Devices: Translating Raymond Chandler." The Translator 8:2 (2002), p. 195-220.

Antonopoulou, Eleni en Kiki Nikiforidou. "Deconstructing Verbal Humour with Construction Grammar.” In Cognitive Poetics. Goals, Gains, and Gaps, onder redactie van Geert Brône en Jeroen Vandaele. Berlin, New York: Mouton de Gruyter, 2009, p. 289-318.

Bellos, David. Is That a Fish in Your Ear? Translation and the Meaning of Everything. New York: Faber and Faber, 2011.

Booth, Wayne C. A Rhetoric of Irony. Chicago: University of Chicago Press, 1974.

Chandler, Raymond. The Lady in the Lake. New York: Alfred Knopf, 1945/1943.

Carroll, Noël. Humour: A Very Short Introduction. Oxford: Oxford University Press, 2014.

Chiaro, Delia. "Verbally Expressed Humor and Translation: An Overview of a Neglected Field". Humor 18:2 (2005), p. 135-145.

Delabastita, Dirk. There's a Double Tongue: An Investigation into the Translation of Shakespeare's Wordplay. Amsterdam \& Atlanta: Rodopi, 1993.

Delabastita, Dirk. "Introduction." In: Wordplay and Translation. Themanummer van The Translator 2:2 (1996), onder redactie van Dirk Delabastita, p. 1-22.

Delabastita, Dirk. "A Great Feast of Languages: Shakespeare's Multilingual Comedy in 'King Henry V' and the Translator." The Translator 8:2 (2002), p. 303-340.

Delabastita, Dirk. "Wordplay as a Translation Problem: A Linguistic Perspective.” In: Übersetzung, translation, traduction, onder redactie van Harald Kittel, Armin Paul Frank, Norbert Greiner, Theo Hermans, Werner Koller, José Lambert, Fritz Paul. Berlin: Mouton de Gruyter, 2004, p. 600-606.

Delabastita, Dirk. “Cross-Language Comedy in Shakespeare." Humor 18:2 (2005), p. 161-184.

Del Corral, Irene. "Humor: When Do We Lose It?” Translation Review 27:1 (1988), p. 25-27.

Fish, Stanley. Is There a Text in This Class? Cambridge, Mass.: Harvard University Press, 1980.

Fish, Stanley. "Short People Got No Reason to Live: Reading Irony”. Daedalus 112:1 (1983), p. 175-191.

Franzen, Jonathan. The Corrections. New York: Farrar, Straus and Giroux, 2001.

García Márquez, Gabriel. Cien años de soledad. Madrid: Cátedra, 1991/1967.

Goffman, Erving. Frame Analysis: An Essay on the Organization of Experience. Cambridge, Mass.: Harvard University Press, 1974.

Gruner. Charles R. The Game of Humor: A Comprehensive Theory of Why We Laugh. New Brunswick, N.J: Transaction Publishers, 1997.

Hutcheon, Linda. Irony's Edge. New York: Routledge, 1994.

Landheer, Ronald. “L’ambiguïté: un défi traductologique.” Meta 34:1 (1989), p. 33-43.

Lievois, Katrien \& Pierre Schoentjes (red.). Translating Irony. Themanummer van Linguistica Antverpiensia New Series 9, 2010.

Lindo, Elvira. Manolito Gafotas. Madrid: Alfaguara, 1994.

Lodge, David. The Language of Fiction. London: Routledge, 2002/1966.

Lodge, David. Deaf Sentence. London: Harvill Secker, 2008.

Lodge, David. La vie en sourdine. Traduit par Maurice et Yvonne Couturier. Paris: France loisirs, 2009. 
Marías, Javier. Corazón tan blanco. Barcelona: Anagrama, 1992.

Marías, Javier. Een hart zo blank: roman. Vertaald door Aline Glastra van Loon. Amsterdam: Meulenhoff, 1993.

Marías, Javier. Mein Herz so weiß. Übersetzt von Elke Wehr. Stuttgart: Klett-Cotta. 1996.

Marks, David F. 1973. "Visual Imagery Differences in the Recall of Pictures." British Journal of Psychology 64:1 (1973), p. 17-24.

Melville, Herman. Moby-Dick: or, The Whale. New York: Penguin, 2003/1851.

Melville, Herman. Moby Dick of de walvis. Vertaald door S. Westerdijk. Utrecht en Antwerpen: Spectrum, 1979.

Nietzsche, Friedrich. De genealogie van de moraal: een strijdschrift. Vertaald door Thomas Graftdijk; herzien, geannoteerd en van een nawoord voorzien door Hans Driessen. Amsterdam: Arbeiderspers, 2005 .

Norberg, Ulf. "On Cognitive Processes during Wordplay Translation: Students Translating Adversarial Humor." In Methods and Strategies of Process Research: Integrative Approaches in Translation Studies, onder redactie van Cecilia Alvstad, Adelina Hild \& Elisabet Tiselius. Amsterdam: John Benjamins, 2011, p. 219-229.

Parks, Tim. “The Books We Don't Understand." The New York Review of Books (blog), 15 augustus 2017. https://www.nybooks.com/daily/2017/08/15/the-books-we-dont-understand/. Geraadpleegd 15 maart 2019.

Refsum, Christian. “When Poets Translate Poetry. Authorship, Ownership, and Translatorship.” In Textual and Contextual Voices of Translation, onder redactie van Cecilia Alvstad, Annjo Greenall, Hanne Jansen \& Kristiina Taivalkoski-Shilov. Amsterdam: John Benjamins, 2017, p.101-117.

Santana López, Belén. Wie wird das Komische übersetzt? Das Komische als Kulturspezifikum bei der Übersetzung spanischer Gegenwartsliteratur. Berlin: Frank \& Timme, 2006.

Schoentjes, Pierre. Poétique de l'ironie. Paris: Seuil, 2001.

Tymoczko, Maria. "Translating the Humour in Early Irish Hero Tales: A Polysystems Approach.” New Comparison 3 (1987), p. 83-103.

Queneau, Raymond. Exercices de style, Paris: Gallimard, 1982.

Queneau, Raymond \& Umberto Eco. Esercizi di stile, Turin: Einaudi, 1983.

Vandaele, Jeroen. "Humor Mechanisms in Film Comedy: Incongruity and Superiority." Poetics Today 23:2 (2002a), p. 221-249.

Vandaele, Jeroen. “(Re-)Constructing Humour: Meanings and Means.” The Translator 8:2 (2002b), p. 149-172.

Vandaele, Jeroen. “Narrative Humor (I): Enter Perspective.” Poetics Today 31:4 (2010), p. 721-785.

Vandaele, Jeroen. "Narrative Humor (II): Exit Perspective." Poetics Today 33:1 (2012), p. 59-126.

Vandaele, Jeroen. “On Comic Mental Imagery in Literature: The Case of Manolito Gafotas.” Neophilologus 99:3 (2015), p. 351-370.

Van den Bergh, Hans. Konstanten in de komedie. Een onderzoek naar komische werking en ervaring. Amsterdam: Moussault, 1972

Wood, James. The Irresponsible Self: On Laughter and the Novel. London: Pimlico, 2005. 


\title{
2.7. \\ Vertalen als intertekstuele praktijk ${ }^{1}$
}

\author{
Paul Claes
}

Jede rechte Übersetzung ist Travestie.

Elke echte vertaling is travestie. Ulrich von Wilamowitz-Moellendorff, "Was ist übersetzen ?" (1901)

Veel vertalers zien hun werk als een vorm van imitatie. Ze kopiëren slaafs de kenmerken van het origineel in de doeltekst. Meestal is het resultaat een stroeve weergave in een weinig idiomatische stijl. Beter is het de vertaling te beschouwen als een transformatie. Paradoxaal geeft die het effect van het origineel vaak beter weer dan een schoolse reproductie.

In mijn studie Echo's echo's (2011) laat ik zien hoe teksten ontstaan door hun relatie met andere teksten. Deze intertekstualiteit staat vanzelfsprekend ook centraal in de vertaalpraktijk: vertalen is het omvormen van een grondtekst in de ene taal tot een doeltekst in een andere taal. Hoe dat concreet verloopt illustreer ik hier met de titel van een leerdicht van de Romeinse dichter Ovidius: Ars amatoria (De kunst van de liefde).

Mijn benadering van de intertekstualiteit steunt op de semiotiek. De Amerikaanse filosoof Charles W. Morris onderscheidt drie domeinen in die discipline: syntaxis, semantiek en pragmatiek. De syntaxis behandelt de verhouding tussen de tekens onderling, de semantiek die tussen het teken en zijn betekenis, de pragmatiek die tussen het teken en zijn gebruikers.

Intertekstualiteit is het netwerk van relaties tussen teksten. Iedere tekst verwijst naar andere teksten. Teksten die bepaalde kenmerken met elkaar delen vormen

1 Dit is een bewerking van een stuk dat verscheen in: Letterlijkheid/Woordelijkheid, (red.) E. Hertog \& W. Segers, Antwerpen-Harmelen: Fantom, 1995 (p. 160-166). 
genres. De meeste vertalingen worden uitdrukkelijk gemarkeerd als behorend tot het genre van de vertaalde teksten ('vertaling uit het Latijn', 'vertaald door X'). Dat verschijnsel noemen we de generische of genre-intertekstualiteit.

De specifieke intertekstualiteit is de relatie tussen twee welomschreven teksten, een grondtekst (architekst) en een eindtekst (fenotekst). Iedere concrete vertaling is een vorm van specifieke intertekstualiteit: die tussen de brontekst en de doeltekst. Beide zijn geformuleerd in een andere code, normaliter een natuurlijke taal, maar bevatten toch ongeveer dezelfde informatie.

\section{Syntaxis van de vertaling}

De semiotische syntaxis behandelt de relatie tussen tekens onderling, afgezien van hun betekenis en gebruik. Bij intertekstualiteit gaat het om de relatie tussen twee teksten: grond- en eindtekst. Hun relatie kunnen we beschrijven als een geheel van verschillen tegen een achtergrond van overeenkomst (het interteksteem).

In Vertaling en origineel (1984) denkt Kitty van Leuven-Zwart bij de verschillen vooral aan veranderingen in betekenis, maar natuurlijk spelen ook andere taalniveaus een rol: (typo)grafie, klank, woordplaatsing en zinsbouw. Op elk niveau kunnen we de omvang van het te vergelijken gedeelte bepalen, de overeenkomsten tussen grondtekst en vertaling nagaan en de verschillen als transformaties beschrijven. De vier mogelijke transformaties zijn toevoeging, weglating, vervanging en verplaatsing. Laten we dit illustreren met ons voorbeeld.

De weergave van de titel Ars amatoria als De kunst van de liefde is een vertalende vervanging, waarbij een codewisseling van Latijn naar Nederlands plaatsheeft. Welke informatie daarbij behouden blijft en welke niet, valt op diverse niveaus na te gaan.

Op grafisch niveau bevat de Latijnse titel slechts twee woorden en de Nederlandse liefst vijf. Een 'woordelijker' correspondentie biedt een titel als De liefdeskunst.

Op fonisch niveau bevat het Latijn vier a's, waarvan twee aan het begin van het woord. Om de alliteratie te behouden kunnen we denken aan de vertaling Manieren van Minnen. Die archaïserende titel is meteen een reminiscentie aan een dertiende-eeuws traktaat van Beatrijs van Nazareth: Seven manieren van minne.

Op morfologisch-syntactisch niveau heeft het Latijn een constructie met een substantief en een adjectief, terwijl het Nederlands een substantief met een van-bepaling heeft. Het Latijn kent een dergelijke genitiefconstructie ook: een variant van de titel Ars amatoria is Ars amandi (Kunst van het beminnen). De vervanging van een 
genitief door een adjectief is een courante Latijnse stijlfiguur: de enallage. In het Nederlands bestaat deze syntactische wending ook, maar Amoureuze kunst lijkt een latinisme en Erotische kunst doet wellicht meer aan beeldende kunsten denken.

Op lexicaal-semantisch niveau heeft de term 'ars' een grotere extensie (omvang) dan de standaardvertaling 'kunst'. Het Latijnse woord kan verwijzen naar een wetenschap, een kunde, een theorie, een vaardigheid, een bedrevenheid, een talent, een gewoonte, een vak, een middel, een techniek en zelfs een truc. Dat suggereert weergaven als Liefdeswenken en Liefde in theorie en praktijk.

Het woord 'liefde' is in onze tijd licht verouderd voor de buitenechtelijke relaties waarover de libertijn Ovidius zijn lezers onderhoudt. De titel Kunst der Vrijage van Jan Meihuizen was in 1941 een vondst, maar lijkt nu ietwat belegen. De kunst van het versieren doet meer denken aan kerstballen dan aan wat anders. Verleidingskunst is misschien een leukere weergave.

Ars amatoria is gevormd naar analogie met ars oratoria, of wat onze middeleeuwers 'de const van rhetoriken' noemden. 'Ars' betekent hier zoveel als 'Handboek' of 'Handleiding'. Marietje d'Hane-Scheltema heeft het terecht over Lessen in liefde (2004). Moderner klinkt: Erotisch handboek of Kleine handleiding voor de verleider.

Citaattitels zijn een andere mogelijkheid: De taal der liefde (Gerard Reve), Alles wat $u$ altijd wilde weten over seks (Woody Allen) of De versierkunstenaars (Jitse Schuurmans). Een onverwachte oplossing biedt een vreemde taal. Kama-Soetra betekent in het Indisch 'Handboek voor de liefde'. Zouden we de Ars amatoria niet kordaat De Latijnse Kama-Soetra kunnen noemen?

Modieuze vertalingen verouderen het snelst, zodat de vertwijfelde vertaler zich afvraagt of hij de bekende titel niet beter onvertaald laat. Zo'n herhalende 'vertaling' bestaat voor klassieke werken als de Ilias, de Aeneis en de Divina Commedia. Qua 'letterlijkheid' is Ars amatoria ongetwijfeld de meest accurate weergave van Ars amatoria.

\section{Semantiek van de vertaling}

In de semantiek van de vertaling gaan we op zoek naar de functie van de intertekstuele relatie. We kunnen twee hoofdfuncties onderscheiden: een constructieve en een destructieve. De constructieve functie benadert de grondtekst positief door hem zo goed en zo kwaad mogelijk te bewaren. De destructieve functie laat zich minder gelegen liggen aan de vorm en betekenis van de grondtekst. 
Deze tweedeling is ook op vertalingen toepasbaar. Sommige versies hebben duidelijk een constructieve, conserverende functie, andere een destructieve, transformerende functie. James S Holmes (1976) noemt beide keuzen respectievelijk 'conservering' en 'herschepping'. Conservering gaat samen met exotisering en historisering, dat wil zeggen met een ruimtelijke en tijdelijke toenadering tot de brontekst, de brontaal en de broncultuur. Herschepping gaat samen met naturalisering en modernisering, dat wil zeggen met een ruimtelijke en tijdelijke toenadering tot de doeltekst, de doeltaal en de doelcultuur. In de praktijk zien we soms een mix van conserverende en herscheppende trekken. Hoewel er heden een sterke neiging bestaat om conserverend en dus constructief te vertalen (denk maar aan de slogan 'Men moet vertalen wat er staat'), zal geen enkele vertaler eraan denken een historische tekst, zoals de sonnetten van Shakespeare, in een historiserend, zeg maar zeventiende-eeuws Nederlands over te zetten.

De keuze voor een constructieve of destructieve benadering is sterk door tijdconventies bepaald. Het is boeiend om de metamorfosen van onze Ovidius-titel in de loop van de eeuwen na te gaan. De allereerste Nederlandse vertaling van de Ars amatoria dateert uit 1563. De titel luidt Die Conste der Minnen. Die vrij 'woordelijke' weergave is typisch voor de renaissance, waarin de oudheid als het alleenzaligmakende voorbeeld gold. Een lichte variatie biedt het volksboek uit 1622, met de titel Minne-Kunst. Die vertaling is minder slaafs, en gaat al in de richting van een adaptatie aan het taaleigen.

Wanneer Jacob Westerbaen in 1665 de Ars amatoria vrij bewerkt, doet hij dat onder de merkwaardige titel Avond-school voor Vrijers en Vrijsters. De dichter uit de Gouden Eeuw kent de didactische connotatie van de oorspronkelijke titel, maar denkt de Romeinse situatie om naar de eigen tijd. 'Avond-school' is een ondeugende verwijzing naar het tijdstip waarop vrijers meestal aan de slag gaan. Minder ver in zijn adaptatie gaat Abraham Valentijn in 1678 met zijn Vrij-konst, hoewel ook hij het conventionele 'Minne' inruilt voor het eigentijdse 'vrijen'.

Het duurt nog eeuwen voor het werk opnieuw vertaald wordt. Dat hoeft ons niet te verbazen: voor het burgerfatsoen was de Ars amatoria een immoreel werk. Pas in 1941 verscheen de (weliswaar onvolledige) Kunst der vrijage van Jan Meihuizen. Zoals ik al zei, doet de vrijmoedige titel van toen vandaag ouderwets aan. In 1978 titelde Eddy de Laet zijn vertaling De minnekunst. De auteur liet zich daarvoor blijkens zijn inleiding inspireren door de oude vertaling. De conservatieve benadering ligt in de lijn van de archeologische wijze waarop classici sinds de negentiende eeuw met klassieke teksten omgaan. De destructieve, transformerende vertaalwijze van 
iemand als Ezra Pound blijft in ons taalgebied zeldzaam. We wachten nog steeds op de resoluut moderne vertaler die de Ovidiaanse richtlijnen tot tips voor Tinder transformeert onder de titel: Daten voor dummies.

\section{Pragmatiek van de vertaling}

In de pragmatiek gaat het om de verhouding tussen een tekst en zijn gebruikers. Volgens de theorie van de taalhandelingen is iedere taaluiting een handeling die een bepaalde communicatiehouding vooropstelt. Bij gewoon taalgebruik neemt de spreker zijn woorden voor eigen rekening: hij 'staat voor wat hij zegt'. Bij het vertalen is de situatie anders. Vertalen is immers een plaatsvervangende taalhandeling. Omdat de vreemde taal de communicatie tussen zender en ontvanger bemoeilijkt, is er een intermediair (een tolk of een vertaler) nodig die de boodschap in een voor de ontvanger begrijpelijker taal overbrengt.

De taalhandeling vertalen, of kortweg de vertaalhandeling, is vergelijkbaar met de taalhandeling citeren. Wie woorden citeert, maakt zich meester van andermans tekst. Deze ingreep gaat doorgaans gepaard met enig tekstritueel. Ofwel wordt de oorspronkelijke auteur uitdrukkelijk genoemd ofwel wordt door gebaar, toon, aanhalingstekens of andere indicatoren duidelijk gemaakt dat het om de uitspraak van iemand anders gaat.

Dezelfde omzichtigheid vinden we bij de vertaalhandeling. De vertaler moet aangeven dat hij spreekt of schrijft in de plaats van een ander. Bij een gedrukte vertaling hoort de oorspronkelijke auteur, titel en uitgever vermeld te worden. Wie dat verzuimt, wordt als plagiator beschouwd en is sinds de invoering van het auteursrecht strafbaar.

Onze ideologie beschouwt een tekst als een 'eigendom': zelfs als hij door transcodering van vorm veranderd is, behoort hij nog steeds aan zijn auteur toe. Enigszins in strijd daarmee wordt ook de (geautoriseerde) vertaling zelf door het auteursrecht beschermd. De jongste tijd gelden minder strikte regels. Het vertalend citeren van vreemde teksten is een gebruikelijk procedé in postmodernistische literatuur.

De vertaalhandeling kan vier verschillende functies krijgen, naargelang de grondtekst, zijn auteur, de oppervlaktetekst of de auteur centraal staat.

(1) De vertaalde tekst staat centraal bij de inhoudelijke functie. Een voorbeeld daarvan is het vertalen van een technische tekst, die geen ander dan een utilitair doel heeft. 
(2) De auteur van de vertaalde tekst staat centraal bij de auctoriële functie. De autoriteit is dan haast belangrijker dan wat zij beweert. Een literaire variant is het huldigingscitaat. Zo vertaalt Hugo Claus in zijn gedicht Het teken van de hamster een hele passage uit de tweede canto van Ezra Pound als hommage aan zijn meester.

(3) De vertalende tekst staat centraal bij de integrerende functie. In extreme gevallen kan de herinnering aan de brontekst totaal vervagen. De vertaling wordt dan een zelfstandig werk, zoals dat het geval is bij vele imiterende vertalingen in de renaissance en de barok.

(4) Het subject van de vertalende tekst staat centraal bij de karakteriserende functie. Hierbij kenschetst de vertaler zich gewild of ongewild door zijn wijze van vertalen. Wanneer Rilke bij voorbeeld de gedichten van Valéry vertaalt, schemert zijn eigen idioom zozeer door, dat we die vertalingen meer lezen als eigenzinnige vertolkingen dan als benaderingen van de oorspronkelijke tekst.

Concrete vertalingen verschillen soms sterk omdat ze diverse functies kunnen vervullen. Wie voor een literair lexicon de Ovidius-titel Ars amatoria vertaalt als De kunst van de liefde, kwijt zich behoorlijk van zijn taak. Wie een commerciële titel moet verzinnen voor een Ovidius-versie in een boekenclub, mikt vlak in de roos met een titel als Hoe versier ik de meisjes? Wie het poëtische effect van de alliteratie tot zijn recht wil laten komen, kan kiezen voor Lessen in liefde.

Wanneer deze drie vertalers bij elkaar komen om uit te maken wat de beste titel is, moet wel een Babylonische spraakverwarring ontstaan. De vertaalwetenschap kan de discussie een kader bieden waarin ze hun inzichten voor elkaar kunnen verhelderen. Voorschrijven hoe ze moeten vertalen, kan ze nauwelijks, want net zoals de liefde is de vertaling niet alleen een kunde, maar ook een kunst. 


\section{Bibliografie}

Claes, Paul. Echo's echo's. De kunst van de allusie. Nijmegen: Vantilt, 2011 (met verdere bibliografie over de intertekstualiteit).

Holmes, James S. “De brug bij Bommel herbouwen.” De Revisor 3:5 (oktober 1976), p. 36-39.

Morris, Charles William. Foundations of the Theory of Signs. Chicago: University of Chicago Press, 1951.

Ovidius Naso, Publius. De kunst der vrijage: twintig eeuwen oude maar niet verouderde liefdeswenken. Bewerkt door Jan Meihuizen. Amsterdam: Strengholt, 1941.

Ovidius Naso, Publius. Lessen in liefde. Vertaald door Marietje d'Hane-Scheltema. Amsterdam: Athenaeum-Polak \& Van Gennep, 2004.

Ovidius Naso, Publius. De minnekunst \& Remedies tegen de liefde. Vertaald door Eddy de Laet. Antwerpen: Standaard Uitgeverij, [1978].

van Leuven-Zwart, Kitty. Vertaling en origineel. Dordrecht: Foris Publications, 1984.

von Wilamowitz-Moellendorff, Ulrich. "Was is Übersetzen?” In Reden und Vorträge. Berlin: Weidmannsche Buchhandlung, 1901. 



\section{Dp| III \\ Een focus \\ op genres}





\title{
3.1. \\ Het vertalen van narratief proza
}

\author{
Franco Paris
}

Kenmerkend voor mijn enigszins hybride positie is het feit dat mijn activiteit als het ware beheerst wordt door twee tegenstrijdige, soms polair tegengestelde principes. Enerzijds verwacht men - lees collega's en studenten - van mij als docent/ wetenschapper - dat ik over geldende regels schrijf of praat, anderzijds besef ik al te goed - als literair vertaler - dat bepaalde strategieën en keuzes niet te verantwoorden zijn vanuit een vertaalwetenschappelijk perspectief, maar eerder het resultaat zijn van intuitie of onbewuste processen. In mijn bijdrage kies ik niet voor de onderzoekende maar voor de vertalende kant en bespreek ik geen theoretische aspecten, die trouwens elders in deze bundel aan de orde komen. Ik concentreer me op interessante kwesties betreffende de vertaling van drie Nederlandstalige romans met een gecompliceerde vertelstructuur: Johannes Viator (1892) van Frederik van Eeden, Elias of het gevecht met de nachtegalen (1936) van Maurice Gilliams en De verwondering (1962) van Hugo Claus. Het eerste boek wordt overschaduwd door het succes van andere werken van dezelfde auteur - zoals de drie delen van De kleine Johannes (1887-1906) - de laatste twee hebben al lang de status van een canoniek werk.

Ik probeer dus, voornamelijk aan de hand van mijn eigen ervaring, om bepaalde aspecten van het vertalen van drie memorabele teksten in kaart te brengen. Ik zal het niet hebben over de relatie tussen vertaling en de theorievorming erover, maar zal de nadruk leggen op de realiteit van het vertaalproces, op vragen die de literair vertalers meestal bezighouden tijdens hun dagelijkse portie vertalen: wat staat er eigenlijk in de tekst? De praktische werkwijze die de Engelse linguïsten Leech en Short hebben ontworpen om een literaire prozatekst te analyseren (Leech \& Short 2007) is hier evenwel van toepassing: wat is de specifieke stijl van een bepaald boek? Hoe kunnen wij die weergeven? "De stijl als het DNA van een auteur" (Anbeek \& Verhagen 2001: 2), hier gaat het uiteindelijk om. De zaak is om alle nuances aan te kunnen voelen. Het is een kunst om niet in de valkuil te stappen van een te trouw blijven aan de 
structuur van de brontekst, maar het is even verkeerd om in de tegenovergestelde valkuil te vallen van een te dichterlijke herschepping. De uiteindelijke vraag is: is de definitieve versie - indien die bestaat - als het resultaat van ontelbare keuzes en van een individuele winst- en verliesrekening wel enigszins acceptabel?

\section{De woordkunst en de ik-figuur: lexicale bijzonderheden en afwijkingen van het normale taalgebruik}

In 1892 publiceert Frederik van Eeden (1860-1932) Johannes Viator, het boek van de liefde, een minder bekend boek dat toch een zeer belangrijke rol gespeeld heeft in het leven van de schrijver. Het gaat in feite om een cruciale tekst. Dat het boek formeel en inhoudelijk heel opmerkelijk is blijkt al uit de eerste reacties van de critici (Fontijn 1999: 334-337). Het hoofdthema was zeker niet irrelevant: hoe verhoudt seks zich tot geestelijke liefde? Wat zijn de gevolgen van de eeuwige strijd tussen Licht en Duisternis, van het conflict tussen ziel en zinnen? De liefde wordt hier voorgesteld als een afspiegeling van een goddelijke, ordegevende kracht, met verwijzingen naar Plato en Dante. Heel problematisch was trouwens ook de stijl van het boek, dat de auteur zelf als 'lyrisch-proza' of als 'proza-gedicht' karakteriseerde. Het is wel zo dat tijds- en plaatsbepalingen ontbreken en dat de schrijver een beroep doet op allerlei poëtische procedés, van synesthesie en alliteratie tot neologisme. ${ }^{1}$ De kritieken van de collega-schrijvers waren bepaald niet mild: Van Eeden maakte zich volgens Verwey schuldig aan retoriek en volgens Van Deyssel aan een "vreselijke lelijkheid (...) gezwellen van valsch gevoel en fletse, holle voorstellingen”. In een brief van 15 september 1893 aan Diepenbrock legt Van Eeden uit dat hij een organisch geheel wou creëren: "Dat ik iets in het boek zou hebben gebracht, verleid door woord-charme, is mij een geheel onverstaanbaar idee;" Andere recensenten zijn wel vol lof over zijn taal: "Er staan verwonderlijk mooie stukjes beeldend proza in Johannes Viator", beweert Frans Coenen (1979: 244) die het volgende voorbeeld vermeldt:

Maar hier rees de morgen sonoor en helder, en droegen de bergen lichtende wolk-kransen om 't donkergroene hoofd, - en de tuin was zonnig en dierbaar beneden, liggend vol rozen, kleurfonkelend gebedde bloemen, schitterend blauw en warm rood, in dampige, warme morgenzon. Hier wilde ik het gras wel kussen

1 Zie ook hoofdstuk 2.4. 
en beide handen zacht houden op de rijke aarde. (...) De avondstond vlamde zijn mooist, de rotsen antwoordden met somber-rossen vrede het hooge hemelrood, de vloeiende rivier wist het en was licht, de huizen der menschen overal, wit-gelukkig in het groen. En dus mochten de kleine menschen blij zijn en zich in lachen bewegen. Zij deden muziek door 't heele dal. (Van Eeden 1979: 49)

Mijn Italiaanse vertaling luidt:

Ma qui sorgeva il mattino sonoro e chiaro, e la cima verdescura dei monti era cinta da corone di nuvole luminose, in basso il giardino era assolato e ameno, colmo di rose, di fiori adagiati sfavillanti di colori, risplendenti d'azzurro e di rosso caldo, nel sole del mattino caldo e pieno di vapori. Qui avevo voglia di baciare l'erba e di poggiare dolcemente le mani sulla ricca terra. (...) Il tempo della sera mandava le sue fiamme più belle, le rocce rispondevano con una pace color fulvo cupo all'alto rosso celeste, il fiume che scorreva lo sapeva ed era luminoso, le case degli uomini dappertutto, bianca felicità nel verde. E così i piccoli uomini potevano esser lieti e muoversi con allegria. Facevano musica per tutta la valle (Van Eeden 1996: 32-33).

Waar wordt belang aan gehecht, wat valt stilistisch op? Dit veelvuldige gebruik van beschrijvende bijvoeglijke en zelfstandige naamwoorden is een belangrijk stijlkenmerk dat mijns inziens absoluut bewaard moet worden in een vertaling. Zinnen als "de avondstond vlamde zijn mooist" - Bijbels aandoend proza - en "huizen (...) wit-gelukkig in het groen" zijn heel ongewoon, maar dat maakt juist het verschil uit: "het geheim zit in de beslissing het gebruikelijke beeld te vermijden" (Wood 2012: 101). Omdat zulke effecten - de innerlijke spanning en de lyrische openbaringen - van fundamenteel belang zijn, zou men de vertaler misschien bepaalde vrijheden kunnen gunnen ten opzichte van de woordkeus: bijvoorbeeld ameno - lieflijk, bekoorlijk, 'literair' klinkend - voor 'dierbaar' en de twee vormen adagiati (gebedde) en muoversi con allegria (zich in lachen bewegen) om acconsonanties - respectievelijk poggiati en valle - tot stand te brengen. In een andere passage gaat Johannes een immense strijd aan en maakt hij een hallucinerend gevecht mee tussen een 'witte' en een 'grauwe' held, waarschijnlijk een verwijzing naar de nietzscheaanse fascinatie voor de held:

Zoo was ook mijn held volmaakt, zijn vuisten waren stukken rots, zijn haar was de vliegende nevel, zijn stem het gebrul der zee. Hij kon slapen op harde steenen en zwemmen in den stormgolf. Hij leefde als de zeearend van roof en moord. Hij 
dronk en zong in den kring zijner helden, en lachte dat het daverde in den wind, en schreide met luid gehuil om der dood zijner zonen. Hij vreesde niets, mensch noch dier, de koude niet en den storm niet, noch de woedende zee, noch den eeuwigen dood. (Van Eeden 1979: 27)

In deze passage is er een groot gevoel voor ritme en klank. Alles wordt fraaier dankzij het spel met de oo- en $u i$-klanken en opvallende en minder opvallende assonanties. Het resultaat is een goed en strak gedoseerd ritme. En nu de Italiaanse vertaling, die ook daarnaar streeft met onder meer het aanbrengen van een gewijzigde interpunctie:

Allo stesso modo era perfetto il mio eroe, i suoi pugni erano pezzi di roccia, $i$ suoi capelli nebbia volteggiante, la sua voce il mugghì del mare. Poteva dormire sulla dura pietra e nuotare nei marosi. Viveva, come l'aquila di mare, di rapina e omicidio. Beveva e cantava nella cerchia dei suoi eroi, e il suo riso rimbombava nel vento e piangeva a dirotto per la morte dei suoi figli. Non temeva niente, né uomini né animali, né il freddo o la tempesta, né la furia del mare, né la morte eterna. (1996: 24)

Johannes Viator is tegelijkertijd mystiek getint en heel persoonlijk. Frederik van Eeden werkte er twee jaar lang aan, en hoewel de ik-figuur van het boek en de schrijver niet altijd op elkaar lijken, is het een feit dat de tekst door de stormachtige relatie van de auteur met Betsy geïnspireerd werd en dat het thema van de verhouding tussen liefde en lust een cruciaal en onopgelost probleem was voor Van Eeden zelf.

Het meesterwerk van Maurice Gilliams (1900-1982), Elias of het gevecht met de nachtegalen, is ook sterk autobiografisch, maar beide boeken hebben veel meer met elkaar gemeen. Het zijn geen gewone romans, eerder een weerspiegeling van een existentialistisch programma met een steeds terugkerend verlangen naar zuiverheid en naar de verlossing van de zonde. Beide teksten zijn verder associërend, de beeldenstroom is vaak sterker dan de verhaallijn en, ten slotte, in beide gevallen leggen de auteurs de nadruk op het waarnemende bewustzijn van een jonge ik-figuur. In Elias kijkt de lezer minder uit naar "de verdere lotgevallen van verschillende personages, dan dat hij zich bewust wordt van iets dat veel dieper ligt” (De Jong 1984: 96). Gilliams schetst de poëtische, introverte ervaringswereld van een overgevoelige jongen met een taal die weliswaar minder hoogdravend en profetisch is dan die van Johannes Viator maar zeker lyrisch van aard. "Elias is niet enkel de uiting van een zeldzaam levensgevoel, het is ook een verruiming en een verinniging van het 
uitdrukkingsvermogen van onze taal", schreef Lebeau een jaar na de verschijning van het boek (1937: 473). Zijn herinneringsproza weerspiegelt de structuur van een klassieke sonate, met een beek en een kasteel als hoofdmotieven.

In een van de mooiste passages onderzoekt Elias de viool van de overleden grootvader in de boekenkamer van zijn slapende tante. Het boeiende van dit fragment is dat wij, samen met hem, de ruimte van de verbeelding betreden. Via het muziekinstrument komt hij als het ware in contact met zijn grootvader, beweegt hij zich in een 'sacrale' ruimte:

Als ik binnen in de viool kijk, zie ik er kleine stofvlokjes wonen en ik kan aan de bekoring niet weerstaan om hun vrede met een potlood te verstoren. 's Avonds kwam grootvader in deze doodschvoorname boekenkamer muziek maken. (...) Ik heb mij over het instrument gebogen en mijn wimpers hebben de snaren aangeraakt; begeerlijk drinken mijn oogen het donker, dat in de holte woont, en hoe meer ik in dit spel volhard, leef ik en ben gevangen en hang er in. Als ik daarna een blik in de lichte, koele ruimte werp, gevoel ik als het ware mijn eigen knokige hardheid door een onzichtbare levensgeest overvleugeld. Is het hier een wereld, waar de dingen nimmer genoeg en slechts vergankelijk wortelschieten, in de zwarte aarde van droefenis en verveling?

Wat valt hier inhoudelijk op? In zo'n suggestieve tekst is de nuance alles. Hoe geef je deze sfeer weer? Bekijken we dit even concreter aan de hand van respectievelijk de Engelse vertaling van André Lefevere (1995) en de Franse versie van Saint-Rémy (1968).

When I look inside the hollow of the violin I see small particles of dust living there and I cannot resist the temptation to disturb their peace with a pencil. Grandfather used to come and play at night in this very plush room full of books. (...) I bent over the instrument and my eyebrows touched the strings; my eyes greedily drink the dark that lives in the hollow, and the more I persevere in this game the more I am alive and trapped and caught up in it. When I cast a glance at the light, cool space around me afterwards, I feel how my own bony hardness is eclipsed by an invisible spirit of life. Is this a world, here, where things never strike root deep enough and never for good in the dark soil of sadness and boredom? (1995: 74-75)

J'examine la cavité du violon; j'aperçois qu'elle est habitée de menus flocons de poussière et je ne puis résister à la tentation de troubler leur paix à l'aide d'un crayon. 
Le soir, grand-père avait coutume de jouer de la musique dans cette bibliothèque d'une distinction mortelle. (...) Je me suis penché sur l'instrument et mes cils ont touché les cordes; mes yeux boivent avec délices les ténèbres habitant la cavité, et plus je m'obstine à ce jeu, plus je vis, plus je subis leur emprise; à certains moments, j'ai l'impression de me mouvoir dans un vide. Lorsqu'ensuite, je scrute la pièce froide et lumineuse, $j$ 'ai la sensation que quelque esprit invisible, mais bien vivant, protège ce qu'il y a en moi de dur et de noueux. Ce lieu-ci, mérite-t-il bien le nom de monde habitable? Les choses ne s'enracinent jamais suffisamment, mais seulement de façon passagère, en cette terre obscure de tristesse et d'ennui. (1968: 122-123)

Beide vertalers streven ernaar om een vlot lopende en mooie tekst te creëren, maar de Engelse vertaling is duidelijk letterlijk - dus trouwer aan de oorspronkelijke tekst - en minder creatief dan de Franse. Saint-Rémy houdt rekening met het feit dat de syntaxis van het Nederlands anders is dan die van het Frans door bijvoorbeeld vaak een bijzin door een hoofdzin te vervangen. Heel interessant is de woordkeus van de twee vertalers. Het neologisme doodschvoornaam dwingt de vertalers tot een vondst: Lefevere vertaalt dit woord met plush, 'richly luxurious and expensive', terwijl Saint-Rémy's vertaling afgestemd is op het referentiekader van de brontekstlezer: d'une distinction mortelle. In dit geval is het de Franse versie die dichter bij het origineel blijft. Het valt verder op dat Lefevere, om overvleugeld te vertalen, het mooiere woord eclipsed verkiest boven de meer voor de hand liggende outshined of overshadowed. De erudiete lezer van de doeltekst zal hier mogelijk denken aan het mooie gedicht van Shelley genaamd The moon: "As in the soft and sweet eclipse / When soul meets soul on lovers' lips” (1839: 340). Saint-Rémy verbindt hieraan een totaal andere connotatie, namelijk die van 'bescherming', protège, en maakt een vrije vertaling van deze zin. Over het algemeen hanteert hij een eerder plechtige taal: menus, avait coutume, à l'aide d'un, en cette in plaats van petits, avait l'habitude, avec un, dans cette.

Plush, eclipsed, distinction mortelle zijn interessante pogingen om het gevoelige Nederlands van Gilliams weer te geven. Het ongebruikelijke, het sidderen, de openbaring, dit alles zit in het DNA van de Antwerpenaar:

Doch het gewone, traditionele feitenverhaal zegt mij niets; het verrast me niet; ik word er niet innerlijk door verontrust op zodanige wijze dat ik in de aanwezigheid van het fenomenale word gebracht. Het trilt, het siddert net in mij van onverwachte openbaringen. (Bernlef-Schippers 1965: 65) 
En een verwijzing naar de vreselijke invloed van het saaie vinden wij trouwens ook in Johannes Viator:

Want het vreeselijkste kwaad dat is het wezenlooze, het niet gevoelde kwaad, het doffe, het dorre, het saaie. De waarachtige hel dezer menschen is niet het brandende vuur. Onze hel, onze hel is een Novembermiddag om drie uur, in een burgerstadsachterkamer, die uitziet op een klein tuintje met twee in stroo gepakte stamrozen en een leeg kippenhok - en binnen witte gordijnen en een glimmende tafel en beeldjes op den schoorsteen - en een lucht naar kool, - en een vergulde pendule die een man komt nazien. (Van Eeden 1979: 265)

\section{Registervariatie: identiteit creëren via de taal}

Allesbehalve saai zijn eveneens de plot en de taal van De verwondering (1962). Het proza van deze roman is uitgebreid bestudeerd, met name de rol van de intertekstualiteit en de weergaloze citatenkunst. ${ }^{2}$ De mythische patronen en de oedipale referenties in dit boek zijn grondig geanalyseerd door respectievelijk Weisgerber (1967) en Claes (1984). Andere wetenschappers hebben voortdurend nieuwe aspecten ontdekt, zoals Weverbergh (1963), die van mening is dat de tekst - vanwege zijn immorele karakter - de tijdsgeest weergeeft. Volgens Spinoy (2018) schuift het boek inmiddels, net als de figuur en het hele oeuvre van Hugo Claus (1929-2008), 'allengs op richting historisch patrimonium'. Net zoals in het geval van Johannes Viator en Elias, kunnen wij de auteur niet zonder meer identificeren met de hoofdfiguur en vormt de roman, door de gecompliceerde vertelstructuur, een uitdaging voor critici en voor lezers.

De verwondering wordt verteld door Victor Denijs De Rijckel, een man die in een soort psychiatrische inrichting zit opgesloten, wiens directeur hem de opdracht geeft om zijn verhaal op papier te zetten. Op een gemaskerd bal in Oostende raakt de 37-jarige leraar Engels-Duits in de ban van een intrigerende en verleidelijke maar onheilspellende vrouw, Alessandra Harmedam. Gegidst door zijn leerling Verzele, reist hij haar achterna naar Almout, een kasteel waar hij dan kennis maakt met fascistische vereerders van een legendarische Vlaamse SS'er, een zekere Crabbe. Het resultaat van deze huiveringwekkende confrontatie met dit oorlogsverleden is, na een reeks hallucinerende ervaringen, de totale instorting van de leraar. Behalve dit

$2 \quad$ Zie ook 2.7. 
eerste relaas bevat De verwondering nog een clandestien dagboek, waar indrukken uit de inrichting en commentaren bij het relaas samenvloeien, en een notitieboek met persoonlijke herinneringen van de hoofdfiguur. Bovendien accentueren de aanwezigheid van verschillende wij-passages, die commentaar leveren op enkele gebeurtenissen, en de mystieke samenvloeiing van De Rijckel en de SS-man Crabbe in het laatste deel alleen maar het 'moeilijke' karakter van het boek. Deze complexe en gelaagde tekst kon al bij het verschijnen rekenen op een grote belangstelling maar, zoals gezegd, is er tot nu toe merkwaardig genoeg weinig aandacht geschonken aan de taal en de stijl van dit boek, ondanks de groeiende waardering vanaf de jaren zeventig voor zijn modernistisch-experimentele schriftuur (Spinoy 2018).

Hoe kan je de structuur en de teneur van zo'n boek doorgronden? Hoe kan je als literair vertaler zo'n thematische en talige gelaagdheid weergeven? Hugo Claus herhaalt in verschillende interviews dat het niet om een eenvoudig te lezen roman gaat en dat hij er veel verschillende lagen in heeft gestopt, met als resultaat 'een vrijwel onleesbaar boek'. Vergt zo'n vertaalopdracht een buitengewone begaafdheid? Vertalingen van de roman verschenen onder meer in het Frans (L'étonnement, 1976), Duits (Die Verwunderung, 1979) en Engels (Wonder, 2009). Het is wel zo dat de auteurs van de bovengenoemde versies een opmerkelijke staat van dienst hebben. Devoldere (2000: 94) noemt de Belgische Maddy Buysse, getrouwd met de zoon van de schrijver Cyriel Buysse, een 'grande dame de la traduction' en benadrukt haar sleutelrol in de verspreiding van de Nederlandstalige literatuur in Frankrijk. Zij vertaalde ook andere gedichten, toneelstukken en romans van Hugo Claus: Oostakkerse gedichten (1955), Een bruid in de morgen (1955), Suiker (1958), De hondsdagen (1955), De koele minnaar (1956), Omtrent Deedee (1963), Het teken van de hamster (1979). Zij maakte verder ook vertalingen van teksten van andere belangrijke Nederlandstalige auteurs: Johan Daisne (De man die zijn haar kort liet knippen, 1948 en De trein der traagheid, 1963), Harry Mulisch (Het stenen bruidsbed, 1959), Gerard Reve (De avonden, 1947), Ivo Michiels (Het boek Alfa, 1963) en van Italiaanse auteurs (o.a. Signorina Rosina, 1956, van Antonio Pizzuto). Bijzonder interessant in dit verband is haar zoektocht naar literatuur die Franstalige uitgeverijen aantrok, met name de 'nouvelle, frappante, inattendue' stijl van auteurs als Reve, Michiels, Daisne, Hermans en Claus (Buysse 1969: 55).

De Berlijner Udo Birckholz heeft een geringer aantal vertalingen op zijn naam staan maar speelde wel een prominente rol in de promotie van de Nederlandstalige literatuur, met name van het werk van Cees Nooteboom (Grave 2018: 69), en vertaalde ook uit het Noors (Terje Stigen), het Zweeds (Per Olof Sundman) en het Deens (Skou-Hansen). Hij positioneert zich heel duidelijk ten opzichte van de in het boek 
behandelde thema's. Hij weet de complexiteit ervan 'overtuigend over te brengen, al worstelt hij de hele tijd met het marxistische discours' door De verwondering als het verhaal van de 'Untergang einer Spätbürgerlichen Gesellschaft' (Missinne 2014: 94) te beschouwen. Deze vertaling van Claus opende de rij van een nieuwe reeks, de Niederländische Bibliothek. In zijn inleiding waarschuwt Birckholz de lezer dat hem geen 'comfortabele lectuur' te wachten staat. Indrukwekkend zijn de vertaalprestaties van de Engelstalige vertaler van De verwondering.

Michael Henry Heim, decennialang docent Slavische talen aan de University of California, vertaalde - uit maar liefst zeven talen: Russisch, Tsjechisch, ServoKroatisch, Duits, Nederlands, Frans, Roemeens en Hongaars - meesterwerken uit de wereldliteratuur: onder andere The Unbearable Lightness of Being van M. Kundera en Mr. Century van G. Grass. Voor zijn Wonder ontving hij in 2010 de Amerikaanse PEN Translation Prize, jaarlijks uitgereikt door het PEN American Center en the Book of the Month Club. In het juryrapport staat onder meer:

Michael Henry Heim's outstanding translation has succeeded masterfully in mirroring Hugo Claus's many voices in this novel that reflects a complex, complicated vision of post-World War II Flanders. It is a world that Claus describes in language that is often deeply poetic, and that alternates between simplicity and hyperbole, clarity and obfuscation, fantasy and reality. To capture all of this in English requires an intensely focused mind as well as an acutely sensitive ear. Michael Henry Heim proves to have both.

De Engelse schrijver Tim Parks (2011) legt de nadruk op de extreem lastige taak van het vertalen van Claus in het Engels door hem met niemand minder dan Joyce te vergelijken:

Of course one can translate Joyce's Ulysses, but one loses the book's revealing in its own linguistic medium, its tireless exploration of the possibilities of English. The same is true of a lot of the experimental writing of the 1960 s and 1970s. It is desperately hard to translate the Flemish writer Hugo Claus into English (...) It was when I was invited to review a translation of Hugo Claus's Wonder (1962) (...) that it occurred to me that over the forty years between Claus and the others an important change had occurred. These more recent novels had, yes, been translated, (...) but it was nothing like the far more arduous task of translating Claus and many of his peers. Rather, it seemed that the contemporary writers had 
already performed a translation within their own languages; they had discovered a lingua franca within their own vernacular, a particular straightforwardness, an agreed order for saying things and perceiving and reporting experience, that made translation easier and more effective. One might call it a simplification (...) Naturally, there was an impoverishment.

Drie ervaren en veelzijdige vertalers dus die een literaire en taalkundige uitdaging aangaan. Een van de meest opvallende stilistische kenmerken van De verwondering is de uitgebreide registervariatie. ${ }^{3}$ Ook in deze roman, net als in de twee hierboven behandelde boeken van Van Eeden en Gilliams, schetst de auteur aan de hand van taal en stijl de mentale toestand van de verschillende personages. Veelzeggend is de manier waarop Claus de figuur van de Prefect introduceert. Het hoofd van het Atheneum waar De Rijckel doceert heeft een autoritaire persoonlijkheid en de onaangename neiging om anderen te kleineren: "Wij, mensen, behoren wel tot zijn ras, maar onvolkomen”, merkt de leraar op (Claus 1962: 37). "Gelet op deze typeringen en zijn beroepsstatus is het niet verrassend dat de Prefect met Schoon-Vlaams wordt geassocieerd" (Lemmens 2016: 58). Dit zijn de eerste woorden van deze dominante figuur:

"Beste de Rijckel, vergeef mij als ik uw onderricht onderbreek, het is namelijk van belang, nietwaar, nietwaar, ik had mij voorgesteld, stel u voor, dat gij misschien de vergadering van vanavond over het hoofd zoudt gezien hebben, nietwaar. Dat zou op zijn minst genomen, gesproken, nietwaar, jammer zijn, want ik heb heel wat voor $\mathrm{u}$ op het oog, overigens, gij weet dat, nietwaar, beste de Rijckel, dat ik heel veel voor $\mathrm{u}$ over heb en ik zou u wel iets aan de hand kunnen doen dat $\mathrm{u}$ ten goede zou kunnen komen maar beroepshalve kan ik hier nog niet over uitweiden. Ik spreek, niet?, vanavond dus over, na de dagorde en de kommunikatie van het bestuur omtrent de deelname aan de jaarlijkse reis die naar Salzburg gaat dit jaar, eerst een paar woorden over het gewestelijk Comité en daarna over Wat betekent Mozart eigenlijk voor onze jeugd? En ik dacht dat uw inleiding misschien mijn intense belangstelling voor de jeugdzorg in het licht zou kunnen stellen. Natuurlijk laat ik u vrij om te spreken waarover gij...” Verder? Ik weiger. Verder. Zijn tanden die de -s moeilijk doorlaten. De ouderwetse a, een a uit de tijd van het Schoon Vlaams (Claus 1962: 37-38).

3 Zie ook 2.5. 
Het gaat om een taallaag die voor de buitenlandse talen geen equivalent heeft, maar het is echter zo dat Schoon Vlaams in deze context zo goed mogelijk hoorde aan te sluiten bij een Noord-Nederlands taalregister. Alle vertalers zijn erin geslaagd om de juiste formele toon te vinden:

“Cher de Rijckel, pardonnez-moi si j'interromps votre enseignement, c'est d'une certaine importance, n’est-ce pas, n'est-ce pas, je m’étais imaginé, figurez-vous, que peut-être vous auriez oublié la réunion de ce soir, n'est-ce pas? Ce serait à tout le moins, disons, dommage, n'est-ce pas, car j'ai de grands projets pour vous, d'ailleurs vous savez bien quoi, n'est-ce pas, cher de Rijckel, je tiens beaucoup à vous et j'aimerais vous rendre un service qui vous serait particulièrement utile, mais ma fonction ne me permet pas encore de m'étendre là-dessus. Ce soir, n'est-ce pas, après l'ordre du jour et la communication du comité concernant la participation au voyage annuel qui cette année se rendra à Salzbourg, je dirai quelques mots sur le Comité régional puis sur "Que signifie réellement Mozart pour notre jeunesse?" Et je pensais que votre introduction pourrait peut-être souligner mon intérêt intense pour la formation de la jeunesse. Naturellement, je vous laisse libre de parler de ce que vous ..." Et puis? Je refuse. Ensuite. Ses dents qui laissent difficilement passer les $s$. Ses $a$ emphatiques, à l'ancienne mode. (1976: 63)

"Bester de Rijckel, verzeihen Sie, daß ich Ihren Unterricht abgebrochen habe, es ist nämlich wichtig, nicht wahr, nicht wahr, ich dachte nämlich, denken Sie nur, Ihnen könnte vielleicht die Versammlung heute abend entgangen sein, und das wäre ja, gelinde gesagt, bedauerlich, nicht wahr, denn ich habe viel mit Ihnen vor, Sie wissen ja auch, bester de Rijckel, daß ich eine Menge für Sie übrig habe, nicht wahr, und ich werde auch unterderhand einiges für Sie tun, doch von Amts wegen kann ich mich hier noch nicht darüber verbreiten. Ich rede also heute abend, nicht? Nach der Bekanntgabe der Tagesordnung und dem Bericht des Vorstands über die Beteiligung an der Jahresreise nach Salzburg, nicht wahr? Zuerst ein paar Worte über den Landesausschuß und dann zum Thema "Was bedeutet Mozart eigentlich fur unsere Jugend?”. Vielleicht könnten Sie in Ihrer Einführung mein starkes Interesse an der Jugendfürsorge hervorheben. Doch es steht Ihnen natürlich frei, worüber Sie ..." Weiter? Ich will nicht. Seine Zähne, die das $« \mathrm{~S}$ \ schwer durchlassen. Und dann sein altertümliches $\ll A »$ aus der Zeit des Sonntagsflämischen. (1979: 41) 
"My dear de Rijckel, forgive me for interrupting your class, but it is a matter of great importance, don't you see, don't you see, it occurred to me, if you know what I mean, that you might overlook tonight's meeting, don't you see. And that would be, at the very least, shall we say, a pity, because I have big things in mind for you, and as I am certain you know, do you not, my dear de Rijckel, I am very fond of you and would very much like to render you a service that would be highly beneficial to you, but professional discretion prevents me from going into detail here. I shall be speaking tonight, as you may be aware, after the business meeting and the committee report on the annual trip, which will be to Salzburg this year, on the topic "What Does Mozart Actually Mean to Our Youth?" and I thought your introduction might highlight my deep commitment to the education of our young people. You are free, of course, to speak about whatever you ..." Whereupon? I refuse. Whereupon. His teeth, which have trouble letting s's through. The $a$ ' dating back to the "Fair Flemish" days. (2009: 51)

Het gij/u systeem, een typisch kenmerk van deze tussentaal, blijft uiteraard problematisch, maar vreemd genoeg heeft niemand getracht om de subtiele, veelzeggende verschuiving weer te geven van de hoffelijke aanspreekvorm $u$ naar de informele gij, een vorm die als een geveinsde vriendelijkheid overkomt. Het woord onderricht is veel minder gebruikelijk dan onderwijs en komt wat plechtiger over, terwijl enseignement, Unterricht en class veel neutraler zijn. Interessant is de vertaling van de zin "De ouderwetse a, een a uit de tijd van het Schoon Vlaams". Buysse kiest voor emphatique, hetgeen de plechtigheid van de Prefect accentueert, Birckholz legt de nadruk op het feit dat zijn uitspraak ouderwets is (altertümliches), Heim op zijn beurt vertaalt het letterlijk. Het Schoon Vlaams, het taalregister bij uitstek van ambtenaren en leraren, wordt een sfeeroproepende à l'ancienne mode in het Frans en Fair Flemish in het Engels. Sonntagsflämischen klinkt ongewoon maar is tegelijkertijd herkenbaar voor Duitse lezers.

Het plattere taalgebruik van de verpleegster Fredine is waarschijnlijk nog moeilijker te vertalen. In dit fragment, tijdens een gesprek met de leraar, begint de vrouw te praten over haar neefje Willytje:

"Willytje spreekt al heel goed, weet je dat? Het is ongelooflijk voor ne jongen van maar zo oud. Hij zegt al: bom".

"Bom?"

“Ja, hij kan 'papa' zeggen en 'mama' en 'boeboe', en gisteravond, maar ja, ze zitten d'r genoeg achter, zijn Ma laat hem geen sekonde gerust, de hele tijd spreken ze 


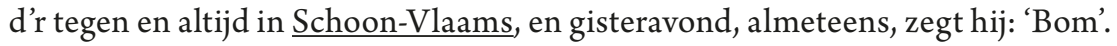
En kontent dat ze waren!"

"Kunnen zij dat kind niet iets anders leren?"

"Waarom? Dat kind kent toch maar ze vader en ze moeder en ze bom?"

"Zijn bom?"

"Maar neen, geen bom gelijk een bom. Oha, dat moet ik vertellen straks, zij gaan zich ziek lachen. $\mathrm{O}$, o, je dacht dat Willytje wilde zeggen: bom, gelijk een bom die kan ontploffen? Maar neen. Bom, Boma, Bomama, jij rare. Of zeggen ze dat niet in je streek in Holland? Hé, wat zeggen ze dan tegen een bomama, voor een grootmoeder?"

"Oma".

"Watte?"

"Oma" (Claus 1962: 83-84).

Er is hier een woordspeling met Bomma, Vlaams voor oma, afgeleid uit het Frans bonne-maman. Buysse en Heim halen in dit geval de Franse term tevoorschijn:

Mais non. Bombe, c'est Bonne-Maman, Bobonne, espèce d'idiot (Claus 1976: 132).

No, no, you must be crazy! It's his way of saying bonne-maman (Claus 2009: 116).

De vertaling van Heim is verder ook expliciterend, terwijl Birckholz integendeel geen enkele 'extra' connotatie geeft aan zijn versie. Dit woordenspel gaat dus gewoon verloren:

Aber nein. Er meinte Boma, Bomama, Sie komischer Kauz (Claus 1979: 93).

Merkwaardig is het feit dat alle vertalers hier het Schoon-Vlaams op een andere manier weergeven: à l'ancienne mode, Sonntagsflämischen en Fair Flemish worden respectievelijk vervangen door beau flamand (p. 132), schönsten Flämisch (p. 93) en High Flemish (p. 115). In het geval van Fredine benadrukken Buysse, Birckholz en Heim dus voornamelijk het talige aspect en niet de weerspiegeling van een persoonlijk eigenschap. Een karakteriserend taalgebruik is niet de enige door Claus gehanteerde strategie om de geestestoestand van de personages weer te geven. In een andere passage van het boek wijkt de schrijver van het normale zinspatroon af om de verwardheid van De Rijckel te tonen. Om Sandra te shockeren liegt hij dat hij besneden is (Missinne 2014: 97): 
Ik dacht dat het precies daarom, omdat ik een Jood ben, dat je zo opgewonden geraakte. Dat het, omdat ik een Jood ben, dat je zo slaafs was, daarna, Sandra mijn engel (p. 210).

Je croyais justement que c'était pour ça, parce que je suis Juif que tu te mettais dans tous tes états. Que, parce que je suis Juif, tu étais si soumise après, Sandra, mon ange (p.322).

Ich dachte, daß es dich deshalb so aufgeregt hat, weil ich ein Jude bin. Daß du mir ebendeshalb so sklavisch verfallen warst, Sandra, mein Engel (p. 239).

And here I thought it was my being a Jew that aroused you so, Sandra, my being a Jew that made you so submissive afterwards, my angel (p. 295).

De Franse vertaling volgt de structuur van deze 'niet-vloeiende' zin en komt niet storend over. De Duitse en de Engelse versies hadden voor hetzelfde patroon kunnen kiezen maar normaliseren liever de zin. Volgens Heim verwijst opgewonden, mijns inziens terecht, naar de seksuele prikkeling (aroused), terwijl Buysse en Birckholz de nadruk leggen op de zenuwachtige stemming van de leraar, met een duidelijke betekenisverschuiving. De eerste opteert voor dans tous tes états (in alle staten), de tweede geeft de voorkeur aan aufgeregt (opgewonden in ruime zin) boven erregt (seksueel opgewonden). Het is alweer een kwestie van nuances.

\section{Conclusie}

Het is uiteraard van essentieel belang dat een literair vertaler de kern van het boek - de stijl van de auteur - kan doorgronden en nabootsen in de doeltaal. "Stijl is in feite een net zo ongrijpbaar begrip als betekenis. Maar dit ontslaat de vertaler natuurlijk niet van de plicht om zich een idee te vormen van de stijl van de tekst die hij gaat vertalen" (Steenmeijer 2015: 18). Het is de taak van de vertaler om de stem van de schrijver te ontdekken. De woordenschat, de zinsstructuur en de registers die Van Eeden, Gilliams en Claus boven water halen plaatsen zelfs de meest ervaren vertalers voor grote moeilijkheden. In de bovengenoemde romans staat de rijke taal centraal. "A good deal of literary language is copious and exuberant", beweert Eagleton (2013: 192). Bij deze auteurs gaat woordkunst gepaard met het subtiel aanduiden 
van gevoelens en gedachten, vaak met het uiten van de subjectieve wereld van respectievelijk Johannes, Elias en Victor. Zij leggen daarbij vaak de nadruk op het verrassende, het ongebruikelijke, het afwijkende. Dit weergeven vergt inderdaad een intens geconcentreerde geest en is tevens een fantastische uitdaging voor een literair vertaler.

\section{Bibliografie}

Anbeek, Ton \& Arie Verhagen. "Over stijl." in Neerlandistiek 1 (2001), p. 1-26.

Bernlef, J. \& Schippers, K. “Gesprek met Maurice Gilliams.” De Gids, 128 (1965).Via DBNL: https:// www.dbnl.org/tekst/_gidoo1196501_01/_gidoo1196501_01_oo11.php. Geraadpleegd 15 maart 2019.

Buysse, Maddy. "Quelques notes sur l'évolution de la littérature néerlandaise comparée à celle de la littérature française.” Ons Erfdeel 13 (1969-1970), p. 54-55. Via DBNL: https://www.dbnl.org/ tekst/_ons003197001_01/_onso03197001_01_0084.php. Geraadpleegd 15 maart 2019.

Claes, Paul. De mot zit in de mythe. Hugo Claus en de oudheid. Amsterdam: De Bezige Bij, 1984.

Claus, Hugo. De verwondering. Amsterdam: De Bezige Bij, 1962.

Claus, Hugo. L'étonnement. Vertaald door Maddy Buysse. Paris: Stock, 1976.

Claus, Hugo. Die Verwunderung. Vertaald door Udo Birckholz. München: Limes Verlag, 1979.

Claus, Hugo. Wonder. Vertaald door Michael Henry Heim. New York: Archipelago Books, 2009.

Coenen, Frans. Studiën van de Tachtiger beweging. Utrecht: Reflex, 1979. Via DBNL: https://www. dbnl.org/tekst/coenoo6studo1_01/.Geraadpleegd 15 maart 2019.

Devoldere, Luc. 2000. “Actuelles.” Septentrion 29 (2000), p. 92-95. Via DBNL: https://www.dbnl.org/ tekst/_sep001200001_01/_sepo01200001_01_0076.php. Geraadpleegd 15 maart 2019.

Eagleton, Terry. How to read literature. New Haven: Yale University, 2013.

Eeden, Frederik van. Johannes Viator. Het boek van de liefde. Katwijk aan Zee: Servire, 1979.

Eeden, Frederik van. Johannes Viator. Il libro dell'amore. Vertaald door Franco Paris. Roma: Tilopa, 1996.

Fontijn, Jan. Tweespalt. Het leven van Frederik van Eeden tot 1901. Amsterdam: Querido, 1999.

Gilliams, Maurice. Elias of het gevecht met de nachtegalen. Amsterdam: Meulenhoff, 1943.

Gilliams, Maurice. Elias ou le combat contre les rossignols suivi de Monsieur Albéric. Vertaald door Saint-Rémy. Antwerpen: Librairie des Arts, 1968.

Gilliams, Maurice. Elias, or The struggle with the nightingales. Vertaald door André Lefevere. Los Angeles: Sun \& Moon Press, 1995.

Grave, Jaap. "Gutachten in der DDR. Braet, Boon und Nooteboom anders gelesen." In Lut Missinne \& Jaap Grave (red.). "Tussen twee stoelen, tussen twee vuren. Nederlandse literatuur op weg naar de buitenlandse lezer", Lage Landen Studies 10. Gent, 2018, p. 57-73.

Jong, Martien J.G. de. Maurice Gilliams. Amsterdam: Meulenhoff, 1984.

Lebeau, Paul. “Gilliams' Elias.” Dietsche Warande en Belfort, 37:6 (1937), p. 473.

Leech, Geoffrey \& Short, Mick. Style in Fiction. Edinburgh: Pearson Education, 2007. 
Lemmens, Wendy. "Schamoteren met de grote woorden. Registervariatie in Hugo Claus' De verwondering (1962)." Internationale Neerlandistiek, 54:1 (2016), p. 53-71.

Missinne, Lut. "Vertalingen." In Mathijs Sanders \& Tom Sintobin (red.). Lezen in verwondering. Veertien leeswijzers bij een roman van Hugo Claus. Nijmegen: Vantilt, 2014.

Parks, Tim. "Your English is showing." The New York Reviews of Books, June 15 (2011), https://www. nybooks.com/daily/2011/o6/15/english-showing/. Geraadpleegd 15 maart 2019.

Shelley, Percy Bysshe. The Poetical works. London, 1839.

Spinoy, Erik. “Onafkrabbaar cretinisme.” De Reactor (2018), https://www.dereactor.org/teksten/ onafkrabbaar-cretinisme. Geraadpleegd 15 maart 2019.

Steenmeijer, Maarten. Schrijven als een ander. Over het vertalen van literatuur. Amsterdam: Wereldbibliotheek, 2015.

Weisgerber, Jean. "Proefvlucht in de literaire ruimte (2). De verwondering." Nieuw Vlaams Tijdschrift, 20:1 (1967), p. 60-78.

Weverbergh, Julien. "Het kleine koude front van Hugo Claus.” Bok. Kritisch tijdschrift, 1:1 (1963), p. $45-52$.

Wood, James. Hoe fictie werkt, vertaald door Arie Storm. Amsterdam: Querido, 2012. 


\title{
3.2. \\ De regels voorbij: het vertalen van poëzie
}

\author{
Onno Kosters
}

Robert Frost heeft nooit gezegd: Poetry is what is lost in translation. Maar wat dan wel? "I'd like to say, guardedly, that I could define poetry this way: it is that which is lost out of both prose and verse in translation. That means something in the way the words are curved and all that - the way the words are taken, the way you take the words" (Brown 2005; mijn cursivering). Niet alleen een heel voorzichtige uitspraak dus, maar ook een tamelijk ondoorzichtige: "something in the way the words are curved and all that - the way the words are taken, the way you take the words" - het lijkt wel poëzie! Toch wordt dit 'citaat' onwaarschijnlijk vaak aangehaald (googelt $\mathrm{u}$ het maar eens). "Poetry in translation is like taking a shower with [a] raincoat on”, een zin die wordt uitgesproken door een Japanse dichter in de film Paterson van Jim Jarmusch (2016), is er een variant op. Hij lijkt iets te beweren over het gebrekkige effect van poëzie in vertaling, maar geeft slechts blijk van een grappig geformuleerde (en qua strekking helaas populaire), maar zeer particuliere opvatting, die weinig zegt over poëzie in vertaling, en eerder voortkomt uit romantische clichés:

Het standaardbeeld van de dichter als eenzaam genie, ver verheven boven de massa, van de sensibele, sensitieve geest die oorspronkelijke en unieke kunst schept uit de bron van zijn ziel (...) - het zijn allemaal ideeën die hun oorsprong vinden in het romantische denken (...). Als alles aan de kunst uniek is en authentiek (...), kan vertaling alleen maar falen, alleen maar verlies opleveren, kunnen vertalingen alleen maar tweedehands zijn. (Koster 2004: 22)

Veel versregels, zelfs hele gedichten zowel uit talen die mensen (denken te) kennen als uit hen volstrekt onbekende, zijn echter 'tweedehands' tot hen gekomen; dat feit doet blijkbaar weinig af aan de waarde die men eraan hecht. Zeker wanneer we het 
over poëzie vertalen hebben, moeten het al te romantische beeld van het gedicht (de brontekst) als uniek en (door bijvoorbeeld vertaling) onvervangbaar fenomeen, een beeld dat door duizenden jaren vertaalpraktijk sowieso al wordt ontkracht, enigszins worden gerelativeerd.

Ik beperk me in dit hoofdstuk tot gedichten waarin lyrische effecten (assonantie, alliteratie, enjambement etc.) en vaak metrum of in ieder geval ritme in het oog springen en die ogenschijnlijk(!) een min of meer herkenbaar verhaal bieden, een gedachte of emotie ontwikkelen of een beeld schetsen (en veelal dit alles tegelijk). Bijvoorbeeld onderstaand gedicht van Philip Larkin:

The Trees

The trees are coming into leaf Like something almost being said;

The recent buds relax and spread, Their greenness is a kind of grief.

Is it that they are born again

And we grow old? No, they die too.

Their yearly trick of looking new

Is written down in rings of grain.

Yet still the unresting castles thresh In fullgrown thickness every May.

Last year is dead, they seem to say,

Begin afresh, afresh, afresh.

Philip Larkin, High Windows (1974)
De bomen

De bomen lopen alweer uit, alsof hun iets te binnen schoot. Traag woelen zich de knoppen bloot of in het groen een doodsklok luidt. Is dat omdat zij verdergaan waar wij vergaan? Welnee, geknot wordt ook hun duur: wat nu ontbot, komt straks in jaarringen te staan. Toch wast dat kroonwerk tot paleis dat vol en rijp zich roert in mei. Verleden jaar is lang voorbij, hoor ik, herrijs, herrijs, herrijs.

Vert. Onno Kosters, 2017

Ik maak in dit hoofdstuk af en toe (kritisch) gebruik van mijn eigen vertaling, bijvoorbeeld ter illustratie van bepaalde beschrijvingen of definities. Verder beperk ik me in dit hoofdstuk tot het vertalen van poëzie als poëzie, tot wat James Holmes noemde 'meta-poems', "translations of poetry (...) that (...) also have the aim of being acts of poetry” (Holmes 1988: 24). Prozavertalingen en imitaties of adaptaties in de doeltaal (Holmes 1988, passim) zijn waardevolle varianten an sich, maar moeten hier onbesproken blijven. 


\section{Poëzie vertalen als daad van ontrouw}

Poëzie, met haar orale oorsprong, vormt de basis van wat we als literatuur beschouwen en omvat vele vormen die vrijwel alle van taal tot taal, van cultureel veld tot cultureel veld, in grote lijnen of op detailniveau verschillen. Wat poëzie uit vrijwel alle windrichtingen verbindt is evenwel de 'gebonden' vorm: poëzie behelst teksten met bepaalde, strak gehanteerde of losjes ingezette vormprincipes die hun oorsprong vinden in de mnemotechniek (als geheugensteuntjes voor de orale dichter): metrum, ritme, strofe-indeling, rijm, klankverwantschap, andere lyrische middelen. Vaak wordt aan poëzie een nadruk op gevoel en verbeelding toegeschreven, maar dat is 'lang niet altijd aan poëzie voorbehouden' ('Poëzie'), en lang niet alle poëzie benadrukt 'gevoel en verbeelding'. Ook belangrijk is de poëtische functie van een tekst, een door de Russische formalisten geïntroduceerd begrip waarmee zij bedoelden 'dat poëzie bepaald wordt door factoren die de aandacht vestigen op de tekst als zodanig' ('Poëzie'; denk aan de ready-made, of het feit dat een tekst überhaupt in een literair tijdschrift of een dichtbundel wordt gepubliceerd). Als er één ding vooropstaat, is het dat micro- (morfemen, woorden), meso- (regels, zinnen, strofen; prosodie) en macro-niveau (het geheel, inclusief eventuele genreconventies, context, intertextualiteit) van een gedicht één en ondeelbaar zijn en als zodanig in het vertaalproces moeten worden meegenomen. Zoals Anneke Brassinga het formuleerde:

Wie een ook maar enigszins gecompliceerd gedicht begint te vertalen, belandt in een immens samenspel van klanken en betekenissen, ritmische patronen en echo's. Alles wat op papier zo stil lag, begint te schuiven en te verspringen. Wat er staat, bepaalt hóe het er staat, en andersom. In een gedicht wordt de taal even abstract als levend. (Brassinga s.d.).

André Lefevere zag als 'opdracht' van de poëzievertaler dan ook de volgende:

The translator's task is precisely to render the source text, the original author's interpretation of a theme expressed in a number of variations, accessible to readers not familiar with these variations, by replacing the original author's variations with their equivalents in a different language, time place, and tradition. Particular emphasis must be given to the fact that the translator has to replace all the variations contained in the source text by their equivalents. (1975: 99). 
'[A]ll the variations': is dat überhaupt mogelijk? Dat hangt er natuurlijk vanaf hoe je het begrip 'equivalentie' hanteert (strikt genomen bestaat equivalentie tussen talen niet, zeker niet als je het hebt over de mogelijke verschillen in associaties en connotaties tussen op het oog 'equivalente' begrippen ${ }^{1}$ ). Hoe dan ook, Burton Raffel stelt dat zelfs waar talen op lexicaal niveau verwant zijn, 'equivalente' overeenkomsten veelal misleidend zijn bij het vertalen van poëzie: “(...) one never translates simply by translating words: it is concepts and structures with which one must work, and words are only one of the many building blocks of which concepts and structures are composed" (1988: 55).

Er bestaan geen gulden en al helemaal geen gouden regels voor het vertalen van poëzie. Sterker, er zijn vermoedelijk evenveel opvattingen over het vertalen van poëzie als vertalers. "What should the verse form of a metapoem be? There is, surely, no other problem of translation that has generated so much heat, and so little light, among the normative critics" (Holmes 1988: 25; zie ook Attwater 2005, passim). Natuurlijk bestaan er normatieve of prescriptieve opvattingen, maar vertalers zelf beschouwen poëzievertalingen meestal, hoezeer ze ook als definitief worden gepresenteerd, als tekstvoorstellen die een grote mate van subjectieve (ofschoon liefst wel beredeneerde) voorkeur in zich dragen, en die significant kunnen afwijken van de brontekstvorm. Een vertaler kan goede redenen hebben voor bijvoorbeeld een andere distributie van syllaben en rijmschema ten opzichte van de brontekst, of voor de vrije vertaling van een gebonden vorm (bijvoorbeeld Jacques Janssens niet-rijmende, alleen ogenschijnlijk de terza rima van het origineel volgende vertaling van Dante's 'Inferno'). Daarentegen vond August Willemsen dat "wanneer de dichter had gekozen voor een rijmende en/of metrische vorm, ik als vertaler die keuze moest respecteren, en wanneer de dichter stamde uit een tijd waarin het usance was rijmend en metrisch te dichten, dan moest ik die tijd respecteren" (Willemsen 2006: 22). Ook dergelijke getrouwheid is een persoonlijke afweging, geen regel. Dat Willemsen onder dichters die hij sprak eenzelfde voorkeur aantrof, is niet meer dan anekdotisch relevant (idem).

\section{Strategieën in kaart}

"Fidelity is indeed the very essence of translation", schrijft de achttiende-eeuwse Engelse dichter William Cowper in het voorwoord bij zijn vertaling van de Ilias, maar 'fidelity', getrouwheid, kent dus vele gezichten. Of zoals John Dryden het formuleert,

$1 \quad$ Zie hoofdstuk 2.1. 
“Too faithfully [translate] is indeed pedantically:'Tis a faith, like that which proceeds from Superstition, blind and zealous" ('Preface'). Dryden redeneerde vanuit het neoclassicistische perspectief van de late zeventiende eeuw, waarin vrijheid binnen gebondenheid de norm was en heeft, juist door deze 'bandbreedte', belangrijke bijdragen geleverd aan het hedendaagse denken over het vertalen van poëzie. Als startpunt wordt vaak Drydens inleiding bij zijn vertaling van Ovidius' Epistles genomen (1680):

No man is capable of translating poetry who, besides a genius to that art, is not a master both of his author's language and of his own; nor must we understand the language only of the poet, but his particular turn of thoughts and expressions, which are the characters that distinguish, and as it were individuate, him from all other writers. When we are come thus far, it is time to look into ourselves, to conform our genius to his, to give his thought either the same turn, if our tongue will bear it, or, if not, to vary but the dress, not to alter or destroy the substance. ('Preface'; vergelijk ook Johnson)

Dryden stelt dus dat de poëzievertaler de doeltaal tot in de puntjes moet beheersen, maar ook de taal (het idiolect) van de bronauteur: diens specifieke wijze van uitdrukken, zijn idiolect, onderscheidt hem van zijn medeauteurs en moeten hem, eenmaal vertaald, ook onderscheiden van alle andere auteurs in de doelcultuur. Aan de inhoud van de brontekst mag tegelijkertijd niets worden gewijzigd, zij het dat deze wel in een andere 'dress' mag (en veelal moet) worden gehesen. In Drydens geval veranderde hij Ovidius' 'dress' (de dactilische hexameter) in 'heroic couplets' (rijmende jambische pentameters), daar deze vorm de Engelse lezer vertrouwder was. Belangrijk om op te merken hier is dat prosodie nooit losstaat van grammatica en syntaxis van een taal. "Verse rhythms are determined by language rhythms", stelt Raffel (1988: 81; cursivering origineel). Zo natuurlijk als Ovidius' Latijn zijn lezer in de oren moet hebben geklonken, zo gewrongen kan deze vorm op de Engelse lezer overkomen. Drydens naturaliserende vertaling van de oorspronkelijke versvorm heeft dus duidelijk te maken met de doeltaal en betreft een functionele keuze; een die de lezer tegemoetkomt, hem niet vervreemdt van de doeltekst. Vertalers blijken constant dit soort pragmatische keuzes te maken en zijn zelden consistent: "In de praktijk doen vertalers (...) een serie pragmatische keuzen, nu eens conserverend, dan weer herscheppend, op de ene plaats historiserend of exotiserend, op de andere moderniserend of naturaliserend, waarbij diverse niveaus afwisselend nadruk krijgen, ten koste van beide andere" (Holmes 1972: 186). 
Dryden was een van de eersten die mogelijke vertaalaanpakken probeerde te systematiseren. Los van de specifieke keuze met betrekking tot de prosodie maakt hij in zijn essay onderscheid tussen

metaphrase or turning an Author Word by Word, and Line by Line, from one Language into another;

paraphrase: Translation with Latitude, where the Author is kept in view by the Translator, so as never to be lost, but his words are not so strictly follow'd as his sense; and that too is admitted to be amplified, but not alter' $\mathrm{d}^{\prime}{ }^{2}$

imitation where the Translator (if now he has not lost that Name) assumes the liberty, not only to vary from the words and sence [sic], but to forsake them both as he sees occasion; and taking only some general hints from the Original, to run division on the Ground-work, as he pleases. (1680)

Dit is een onderverdeling waarop in de eeuwen na Dryden is gevarieerd, die is uitgebreid en verfijnd, maar ze beschrijft nog steeds op een nuchtere, zinnige manier de meest voor de hand liggende 'vertaalstrategieën' die poëzievertalers erop na kunnen houden. Een van de navolgers van Dryden in het systematiseren was de reeds enkele malen genoemde James Holmes, die aan een 'waaier' van mogelijkheden om een gedicht te vertalen, de volgende vier (of eigenlijk vijf) vormen koppelde.

Mimetic form (1988: 26). De doeltekst neemt één op één de vorm van de brontekst over; Homerus wordt in de andere taal, of deze zich er nu voor leent of niet, in dactylische hexameters vertaald (mijn 'parafraserende' Larkin-vertaling is grotendeels 'mimetic'; het metrum leende er zich in dit geval voor).

Analogous form (idem: 26). Net als de 'mimetic form' is dit een 'form-derivative' optie; de vorm van de brontekst is het uitgangspunt, maar er wordt een (meer) geschikte, functionelere vorm in de doeltaal gekozen (Homerus in het Engels in jambische pentameters of in 'blank verse'; 'Pope's Iliad, in rhymed couplets, becomes something very much like an English poem about English gentlemen, for all

2 Mijn Larkin-vertaling zou je een 'paraphrase' kunnen noemen: de auteur volg ik zoveel mogelijk in diens eigen metrum, wat alleen werkt door prominente en betekenisdragende enjambementen waarmee ik een al te dreunend ritme vermijd ['Is dat omdat zij verdergaan / waar wij vergaan? Welnee, geknot / wordt ook hun duur']; wel verander ik duidelijk eenmaal de 'sense': 'castle' werd, om redenen van ritme, assonantie en rijm, 'paleis'. 
the Greek trappings of the fable' [1988: 27]). De 'form-derivative' vertalingen zijn inmiddels overwegend achterhaald, beweert Holmes; meer gebruikelijk werden in de twintigste eeuw de 'content-derivative' en de 'extraneous' vormen.

Content-derivative of organic form (idem: 27). Hier wordt 'vanuit de inhoud' van het gedicht een keuze gemaakt, "allowing it to take on its unique poetic shape as the translation develops" (idem).

De deviant/extraneous form ten slotte (idem) is de imitatie zoals bijvoorbeeld Robert Lowell die beoefende: "The translator making use of this approach casts the metapoem into a form that is in no way implicit in either the form or the content of the original" (idem).

Holmes laat aan de hand van verschillende vertalingen van een passage uit de Odyssee zien dat "there is an extremely close relationship between the kind of verse form a translator chooses and the kind of total effect his translation achieves" (1988: 30). Interessant is dat Holmes' conclusie, dat "[a]s fundamentally pessimistic regarding the possibilities of cross-cultural transference as the mimetic approach is fundamentally optimistic, the organic approach has naturally come to the fore in the twentieth century" (idem 28; mijn cursivering) inmiddels achterhaald lijkt. Veel vertalers geven er tegenwoordig de voorkeur aan zo dicht mogelijk bij de brontekstvorm te blijven.

In zijn studie uit 1975, Translating Poetry: Seven Strategies and a Blueprint, verwijst Lefevere enkele malen naar Holmes, bijvoorbeeld waar hij het heeft over diens "fairly general but no less penetrating comment on the subject: 'no verse form in any language can be entirely identical with a verse form in any other, however similar their nomenclatures and however cognate the languages'” (37-38). Deze opmerking plaatst Lefevere bij zijn bespreking van 'metrical translation', metrisch vertalen analoog aan de brontekst, een van de zeven strategieën die hij bespreekt:

1. Phonemic translation: zuiver op klank (zie Zukofsky/Melnick, hieronder).

2. Literal translation: woord voor woord; zuiver op betekenis; niet noodzakelijkerwijs grammaticaal. August Willemsen rekent kort en bondig af met de mythe van de letterlijke vertaling (woord-voor-woord komt, anders dan bijvoorbeeld bij Holmes (in Holmes 1972), terecht niet eens ter sprake in zijn bespiegelingen): "Letterlijk vertalen is onmogelijk, want de ene taal is, doodeenvoudig, de andere niet” (Willemsen 1987: 31).

3. Metrical translation.

4. Prose translation. 
5. Rhymed translation. "The rhyming translator fights a losing battle against self-imposed restrictions. The target text reads more often than not like an unintentional parody of its source" (1975: 61): Lefevere geeft een nuttig overzicht van mogelijkheden om van de 'losing battle' toch een (pyrrus)overwinning te maken. Mijn Larkin-vertaling is een 'rhymed translation' die naar ik meen van zo'n pyrrusoverwinning getuigt; in strofe twee bijvoorbeeld, 'rijmen' de rijmwoorden ook inhoudelijk met elkaar: 'verdergaan' versus 'staan', 'geknot' versus 'ontbot'.

6. Blank verse/free verse: zuiver op betekenis, wel grammaticaal, eventueel zonder enige formele kenmerken van de brontekst.

7. Interpretation: om de brontekst voor een ander doel toegankelijk te maken, houdt de vertaler zich qua betekenis aan de brontekst, maar varieert hij de vorm.

Lefevere biedt een interessante en kritische blik op de praktijk van het vertalen, maar benadrukt tevens herhaaldelijk dat geen ervan op zichzelf de complexiteit van de brontekst kan overzetten in een doeltekst. Over 'metrical translation', bijvoorbeeld, concludeert Lefevere: “(..) metrical translation, like its literal counterpart (...) succeeds only in distorting the sense, communicative value, and syntax of the source text" (1975: 42; mijn cursivering).

Overwegingen ten opzichte van het doelpubliek worden in Raffels benadering nog zwaarwegender dan bij Lefevere en, met name, Holmes (zonder dat Raffel ook maar één keer naar Holmes verwijst): voor wie vertaal ik dit? Wat heeft het antwoord daarop voor invloed op mijn keuze voor bijvoorbeeld de benadering van cultuurspecifieke elementen? Raffel zegt dat "[v] ery few of those who write about translation (...) are prepared to admit that no single type of translation is 'best' for each and every audience" (1988: 111). Hij onderscheidt aldus vier vertaalstrategieën voor poëzie: formal translation (gericht op wetenschappers en studenten; voor wetenschappelijk gebruik, niet zozeer bedoeld als literaire tekst); interpretative translation (bedoeld voor een breed publiek, dat geïnteresseerd is in een literaire vertaling); expansive (or free) translation (bedoeld voor "those who usually prefer to read something, anything, new rather than anything old"; nogal een onzinspecificatie, die voorbijgaat aan de arbitraire betekenis van oud/nieuw die optreedt zodra er een vertaling in het spel is); imitative translation ("barely translation at all; it is aimed at an audience which wants the work of the particular translator rather than the original poet") (ibid: 110-11).

Raffel geeft zich weinig rekenschap van zijn voorgangers op het gebied van de theorie. Ik vind het lastig om mijn Larkin-vertaling in een van Raffels categorieën te 
plaatsen (maar dat geldt voor meer categoriseringen); ze is 'formal' in de zin dat ik wel zoveel mogelijk het metrum van de brontekst volg; 'interpretative' omdat ik van de doeltekst een heus gedicht probeer te maken, zij het een dat in grote lijnen zowel inhoudelijk als qua vorm overeenkomt met de brontekst; en zeker ook 'expansive', omdat dat bijna niet anders kan: uiteraard is de vertaling 'something new'.

\section{Equivalentie versus interpretatie}

De meeste studies over het vertalen van poëzie, beperken zich tot vertalingen die door een bepaalde graad van 'equivalentie', op zowel inhoudelijk als semantisch niveau, worden gekenmerkt. Anders gezegd: door het idee dat equivalentie überhaupt tot de mogelijkheden behoort, en dat als je dat idee opgeeft, de vertaling geen vertaling meer is, maar een 'versie'. Dat equivalentie-idee laat echter buiten beschouwing dat iedere vertaling per definitie een interpretatie is, hoe trouw of hoe vrij deze ogenschijnlijk ook de brontekst volgt. ${ }^{3}$ Een vertaler verandert altijd; equivalentie is een illusie. Een brontekst komt altijd in reeds door anderen geïnterpreteerde vormen tot de vertaler: de reputatie van een dichter, met alle canoniserende werking van dien, ${ }^{4}$ kleurt een lezing; een wetenschappelijke editie waarin de gedichten worden geïnterpreteerd en geannoteerd alsof die interpretaties en annotaties de enig mogelijke zijn, kleurt een lezing; een fraai vormgegeven 'verzamelde gedichten', met een bepaald font en allerlei parateksten die de lezer in een bepaalde richting sturen (in eerste instantie, die van de aanschaf van het boek!), kleurt een lezing.

Lawrence Venuti neemt op grond van deze overwegingen een radicaal standpunt in: "(...) in the fact that the same source-language poem can support multiple translations which are extremely different yet equally acceptable as poems or translations, we glimpse the possibility that no invariant exists, that the practice of translation is fundamentally variation" (Venuti 2013: 174). Het is een standpunt op grond waarvan vertalers zich veel meer vrijheden kunnen toe-eigenen dan ze misschien wel denken. Ezra Pound zou je, met zijn radicale, op modernistische leest geschoeide poëtica, de illustere voorvechter van deze vrijheden kunnen noemen (in Cathay, 1915, vertaalde

\footnotetext{
Zie ook 1.4, 2.1.

4 Bijna per definitie mag de vertaler zich, volgens de meeste doeltekstlezers, bij een canonieke auteur (zoals Baudelaire) minder vrijheden veroorloven dan bij minder gevestigde namen. Als de vertaler zo brutaal is creatiever dan strikt noodzakelijk te werk te gaan, raakt de discussie al snel verhit (zie bijv. Zeeman 1995 en de Haan 2016).
} 
hij Chinese poëzie aan de hand van Engelse annotaties, zonder een woord Chinees machtig te zijn), op de voet gevolgd door Melnick en Zukofsky (zie Venuti 2013: 174 e.v.).

Maar hoe ver mag je gaan in het opeisen van de vrijheden die 'versioning' (ibid: 174) biedt? Zo ver als je als vertaler verantwoord acht: vertalen betekent per definitie dat je een nieuw product creëert. Een vertaler moet zich rekenschap geven van zijn eigen poëtica en hoe deze zich verhoudt tot die van de bronauteur (als die al te distilleren, of überhaupt eenduidig is) en zich vervolgens afvragen of en in hoeverre hij het zich kan permitteren om vrijheid te nemen. Joanna Richardsons vertaling van Baudelaire's 'Le Chat' laat mooi zien hoe bijvoorbeeld biografische informatie kan meespelen in de keuze voor 'body cinnamon' in plaats van bijvoorbeeld 'brown body' voor 'corps brun' (Baudelaire 1975: 78-79): met 'cinnamon' (kaneelkleurig) wordt Baudelaire's donkere Haitiaanse geliefde Jeanne Duval, die hij in dit gedicht zo sensueel bezingt, meer dan alleen een kleur: een geur, een smaak, een vreemdelinge, het exotische, het verbodene ... Mag dat?

\section{De praktijk: competenties, fasen en samenwerking}

Theorie en praktijk, zoals uit bovenstaande al blijkt, zijn in een reflectie over het vertalen van poëzie onlosmakelijk met elkaar verbonden. Toch kunnen we nu iets gedetailleerder bekijken wat een vertaler moet 'kunnen' en hoe hij te werk kan gaan, opdat de gekozen strategie of strategieën optimaal kunnen worden ingezet. In het hoofdstuk 'Prescriptive' formuleert Lefevere de noodzakelijke competenties van de poëzievertaler als volgt (ik citeer alleen de respectievelijke uitgangspunten): "The ability to comprehend the source text as a whole", "to measure the communicative value as well as the sense of the source text"; "to distinguish between culture-bound and structure-bound time-place-tradition elements in the source text"; "to select (...) a form which will most closely match the position the source text occupies in the literary tradition of the source language"; "to interpret the theme of the source text in the same way as the original author" (1975: 101-04). Deze competenties vormen de praktische basis voor de aanpak van het vertalen van een gedicht.

In 1982 publiceerde de Amerikaanse dichter/vertaler Robert Bly “The Eight Stages of Translation", waarin hij antwoord probeert te geven op de vraag 'What is it like to translate a poem?' (1982: 68). De acht fasen die hij onderscheidt lopen in elkaar over en overlappen elkaar vaak ("[ $\mathrm{t}]$ he difficulties are all one difficulty, something 
immense, knotted, exasperating, fond of disguises, resitant, confusing, all of a piece" [idem]), maar bieden een interessante handreiking voor de poëzievertaler:

- Fase 1: letterlijke vertaling: "we don't worry about nuances (...). We only want the thrust" (1982: 69). Ook Bly predikt het nut van een woord-voor-woord vertaling, zelfs als dat ongrammaticale zinnen in de doeltaal oplevert.

- Fase 2: het ontdekken van wat het gedicht betekent: waar gaat het over?

- Fase 3: die betekenis zien terug te vinden in de letterlijke vertaling (pas in deze fase wordt bij Bly de doeltaal grammaticaal).

- Fase 4: De keuze voor een specifieke taalvariant; in Bly's geval: Amerikaans Engels. Deze fase zal niet altijd relevant zijn. Maar ook registerkeuzes en overwegingen ten aanzien van bijvoorbeeld sociolect of idiolect spelen in deze fase een rol.

- Fase 5: 'tone (...): "Does this last draft have the tone of the German?" (1982: 78; Bly's brontekst betreft een gedicht van Rilke). Hier wordt Bly wat abstracter; het wordt belangrijk om de 'mood' van het gedicht te bepalen: "A poem did not come out of an idea [een al te apodictische claim], but a poem marked a moment when he was able to catch a mood" (idem). Hier stelt Bly dat het daarom belangrijk is dat de vertaler zelf ook poëzie heeft geschreven of schrijft. Daar kun je over twisten; en dat wordt gedaan ook. "The translator of poetry must himself be a poet ...”, stelt Raffel (1982: vii; cursivering origineel; zie verder Bernlef en Tentije, en Naaijkens 2002 en 2010).

- Fase 6: 'sound': ritme, klank; beide komen voort uit 'mood'. "No one can translate well from a poem he or she hasn't learned by heart" (82): dat u het maar weet.

- Fase 7: een brontaalspreker vragen naar de tekst te kijken. ("For beginning translators, this stage is very painful", 1982: 85).

- Fase 8: laatste versie; laatste aanpassingen; geen cruciale elementen herzien, want dan kun je weer helemaal opnieuw beginnen ...

Het onderscheiden van strategieën, competenties en fasen is echter maar een deel van het verhaal. Vertalen van poëzie is in essentie een dynamisch proces waarin verschillende actoren (uitgevers, redacteuren, vaak ook samenwerkende vertalers en soms ook de bronauteur zelf) een rol spelen. Francis Jones bespreekt in Poetry Translation as Expert Action: Processes, Priorities and Networks (2011) de meest recente opvattingen over de 'collaboration' die het vertalen van poëzie is. Zij bevestigt in wezen wat ik hiervoor al een aantal keren aangaf: wie een gedicht vertaalt (zie bijvoorbeeld Willemsen 1987), beweegt zich veelal weinig systematisch tussen de 
strategieën die Dryden, Holmes en Lefevere bespreken, de competenties zoals Lefevere ze formuleert, en de fasen die Bly aangeeft, en maakt daarbij op allerlei wijzen gebruik van een netwerk van experts.

\section{Vertalen en 'zelf' schrijven}

Zoals blijkt uit alle overwegingen en categoriseringen die de revue zijn gepasseerd, beweegt het vertalen van poëzie (en misschien wel van alle genres) zich tussen 'vertalen' en 'schrijven' (in de terminologie van Raffel: tussen 'interpretative' en 'imitative's). Dat is ook de kern van wat Michael Hamburger formuleert over het vertalen van poëzie in zijn nawoord bij zijn vertaling van Paul Celan:

The translation of poems involves two distinct functions and processes, which, for simplicity's sake, I call reading and writing. (...) Most of the perennial debates about what translation can or ought to do hinge on the delicate balance between the two functions and processes - and on the differences, either individual or historical, in the relative importance attached to the one and the other. (...) The individual differences have to do with a translator's character and intentions, with the degree to which translation serves him or her as a pretext for doing his or her own thing, writing, and the degree to which he or she subordinates this purpose to that of bringing the original as close as possible to the reader. (Celan 2002: 405; mijn cursivering)

Wat belangriik is, en door Hamburgers vertalingen van Celan duidelijk wordt, is dat schrijven (dichten) een elementair onderdeel is van het vertalen van het geschreven, het gedichte woord. Je hoeft wellicht niet per se (gepubliceerd) dichter te zijn om poëzie te vertalen, maar je moet als poëzievertaler wel weten wat kan, wat 'werkt' in de doeltaal, hoever je op welk moment kunt gaan in je eigen zinnen, je eigenzinnigheid, welke grenzen je kunt opzoeken, moet opzoeken, moet overschrijden om de zeggingskracht van het origineel op vergelijkbare - nooit dezelfde, wel eenzelfde - wijze over het voetlicht te brengen. Dat kan betekenen, in mijn Larkin-vertaling, dat 'castles' om lyrische redenen één 'paleis' worden wanneer de machtige omvang van de kroon van een boom wordt opgeroepen. Het kan betekenen dat 'Like something almost being said' wordt verbeeld als 'Alsof hun iets te binnen schoot', een interpretatie

$5 \quad$ Zie ook 2.4 en 3.3. 
van de bronregel die wellicht op hetzelfde neerkomt (al is ze misschien te 'mooi'). 'Their greenness is a kind of grief' heb ik tamelijk vrij vertaald als 'of in het groen een doodsklok luidt', wat misschien te 'zwaar' is (en wie weet een oplossing waarin ik te zeer een excuus heb gevonden om 'mijn eigen ding te doen: schrijven', om Hamburgers formulering te vertalen). En waar de bladeren, ten slotte, iets lijken te 'zeggen', neem ik de vrijheid daar van te maken toen het niet anders leek te kunnen dat de verteller wat zij zeggen lijkt te horen. Onverantwoorde perspectiefverschuiving? Er is altijd ruimte voor verandering, verbetering: er is altijd ruimte voor een volgende vertaling.

\section{Bibliografie}

Attwater, Juliet. "Perhappiness: The Art of Compromise in Translating Poetry or: 'Steering betwixt Two Extremes'." Cadernos de Tradução, 1:15 (2005), p. 121-143.

Baudelaire, Charles. Selected Poems. Translated by Joanna Richardson. Harmondsworth: Penguin, 1975. Bax, Marcel en Nanne Steenstra. “That's not Donne, Mr. Huygens!” Regel voor regel. Vertalen en vertalingen: proeven en beschouwingen. Feestbundel voor Prof. W. Blok. Groningen, 1982, p. 35-51.

Bernlef, J, en Hans Tentije. “Bij de poëzie in vertaling." Poëzie in vertaling. Raster 37. Amsterdam: De Bezige Bij, 1986, p. 7-11.

Bindervoet, Erik, en Robbert-Jan Henkes. Help! The Beatles in het Nederlands. Amsterdam: Nijgh \& Van Ditmar, 2003.

Blok, W. "Enkele vertalingen met een woord vooraf." Regel voor regel. Vertalen en vertalingen: proeven en beschouwingen. Feestbundel voor Prof. W. Blok. Groningen, 1982, p. 8-9.

Bly, Robert. “The Eight Stages of Translation.” The Kenyon Review. New Series, 4:2 (Spring 1982), p. 68-89.

Brassinga, Anneke. "Verzoening met het eigen werk." http://www.letterenfonds.nl/nl/essay/24/ verzoening-met-het-eigen-werk. Geraadpleegd 3 september 2018.

Brown, Deborah, et al. Lofty Dogmas: Poets on Poetics. Fayetteville: University of Arkansas Press, 2005.

Celan, Paul, Poems of Paul Celan: A Bilingual German/English Edition. Revised edition, translation Michael Hamburger. London: Anvil Press, 2002.

Cowper, William, The Iliad of Homer, Translated into Blank Verse, 1791. https://www.gutenberg.org/ files/16452/16452-h/16452-h.htm. Geraadpleegd 3 september 2018.

Dryden, John, "Preface concerning Ovid's Epistles" (1680). http://www.bartleby.com/204/207.html. Geraadpleegd 3 september 2018.

Gerbrandy, Piet. "Het lichaam van de tekst." Filter 16:4 (2009), p. 3-9.

Haan, Martin de. "Krenten in de pap." (2016). https://www.dereactor.org/teksten/krenten-in-de-pap. Geraadpleegd 3 september 2018.

Holmes, James. "Forms of Verse Translation and the Translation of Verse Form.” Translated! Papers on Literary Translation and Translation Studies. Amsterdam: Rodopi, 1988, p. 23-34.

Holmes, James. “De brug bij Bommel herbouwen.” (1972). Naaijkens et al., p. 183-188.

Jarmusch, Jim. Paterson. Window Frame Films, 2016. 
Johnson, Samuel, The Idler, 69. History of translation, 1759. http://www.johnsonessays.com/the-idler/69-history-translation/. Geraadpleegd 3 september 2018.

Jones, Francis R. Poetry Translating as Expert Action: Processes, Priorities and Networks. Amsterdam-Philadelphia: John Benjamins, 2011.

Koster, Cees. “Twee liedjes voor één cent: Over vertalingen van poëzie.” Filter 11:3 (2004), p. 21-24. Lefevere, André, Translating Poetry: Seven Strategies and a Blueprint. Assen: Van Gorcum, 1975.

Melnick, David. Men in Aida. Berkeley: Tuumba Press, 1983.

Naaijkens, Ton. "Over doodzonden en dichter-vertalers." De Gids 165:4 (2002), p. 343-349.

Naaijkens, Ton. "Uit hemelen van stilte." Filter 17:2 (2010), p. 7-14.

Naaijkens, Ton, et al. Denken over vertalen. Nijmegen: Vantilt, 2010.

"Poëzie." Algemeen Letterkundig Lexicon. https://www.dbnl.org/tekst/delao12algeo1_o1/delao12algeo1_01_04801.php. Geraadpleegd 3 september 2018.

Pound, Ezra. Cathay. London: Elkin Matthews, 1915.

Raffel, Burton. The Art of Translating Poetry. London: The Pennsylvania State University Press, 1988. Venuti, Lawrence. Translation Changes Everything: Theory and Practice. London: Routledge, 2013, p. 173-192.

Willemsen, August. "De opzettelijke toevalligheid.” Filter 13:4 (2006), p. $20-29$.

Willemsen, August. "Hoe doe je dat nou?” De taal als bril. Amsterdam: De Arbeiderspers, 1987, p. 31-47.

Zeeman, Michaël. "Padam-padam-padam doet de tekstverwerker Provocerende kritieken van een nieuwsgierige flaneur op de kunstsalons Moedige vertaling van Les Fleurs du Mal doet Baudelaire geen recht.” De Volkskrant, 24 februari 1995.

Overige geraadpleegde titels

Anon., "Les fleurs du mal ..." De Volkskrant, 27 januari 1995.

Asscher, Maarten. "Elk droomt eens anders dromen als de zijne." De Gids 165:4 (2002), p. 300-315.

Bellos, David. Is That a Fish in Your Ear? The Amazing Adventure of Translation. London: Penguin, 2011.

Bernstein, Charles. Attack of the Difficult Poems: Essays and Inventions. Chicago: University of Chicago Press, 2011.

Brassinga, Anneke. "Vertalen en dichten." De Gids 165:4 (2002), p. 271-278.

Broeck, Raymond Van den. "Baudelaire driemaal vertaald." Filter 2:2 (1995), p. 32-46.

Colmer, David. “Over het vertalen van 'De danser' van Nijhoff.” http://www.letterenfonds.nl/en/ essay/21/over-het-vertalen-van-de-danser-van-nijhoff. Geraadpleegd 3 september 2018.

Hofstadter, Douglas. Le Ton beau de Marot: In Praise of the Music of Language. New York: Basic Books, 1997.

Jansen, Theo A.J.M. “Woordspeling in vertaling: 'a sad tale'.” Regel voor regel. Vertalen en vertalingen: proeven en beschouwingen. Feestbundel voor Prof. W. Blok. Groningen, 1982, p. 76-89.

Kloos, Hans. http://home.kpn.nl/kolos/vertalen/eecOver.htm. Geraadpleegd 3 september 2018.

Nijmeijer, Peter. "Zien = geloven." Hetzelfde anders. Buitenlandse dichters en hun Nederlandse vertalers. Eindhoven, 1980, p. 26-31.

Rodenko, Paul. “Enkele gedachten over het vertalen van poëzie.” https://www.dbnl.org/tekst/ rodeoo6tusso1_01/rodeoo6tusso1_01_0oo6.php. Geraadpleegd 3 september 2018. 


\title{
3.3. \\ Enige hardop uitgesproken gedachten over het vertalen van theater
}

\author{
Erik Bindervoet
}

\section{De theorie}

Er is een theorie die zegt dat gedachtes zich niet in woorden afspelen in de hoofden van de mensen, en ook niet in beelden, maar in iets anders, waar dan weer woorden of beelden van gemaakt worden. Ook mensen die niet kunnen spreken hebben gedachten. (Om maar te zwijgen van de mensen die niet kunnen denken maar wel spreken.) En mensen kunnen ook spreken zonder woorden. Gebarentaal is bijvoorbeeld een taal zonder woorden, maar wel de natuurlijke uitdrukkingswijze voor doven. Veel gedachten spelen zich op een non-verbaal niveau af. Neem bijvoorbeeld de taal der liefde. Of non-verbale agressie. Alleen de gedachte eraan leidt al tot (over)verhitting.

We onthouden van veel mededelingen vaak wel de teneur, maar zelden de precieze bewoordingen en als je een taal leert heb je vaak het idee dat de woorden nooit precies uitdrukken wat je ermee zou willen uitdrukken. Dat is waarschijnlijk wat er achter Goethe's adagium steekt: zo gauw men spreekt, begint men te liegen. Omdat er wel woorden voor dingen zijn, maar geen dingen voor woorden, volgens Albertus Magnus, de leermeester van Thomas van Aquino.

Met andere woorden: de taal heeft zijn grenzen. Of om het met de Bee Gees te zeggen: "It's only words, and words are all I have ..." Iemand die ook voortdurend tegen de grenzen van de taal op liep, en hard ook, was de filosoof Ludwig Wittgenstein. Voor hem toonde de betekenis van een woord zich in het gebruik en die betekenis was nooit een-op-een. Het was een wolk van niet-weten, tasten in het halfduister: ik doe alsof ik jou snap en dan doe jij of je mij snapt.

- Afgesproken?

- Afgesproken. 
Het is maar een spelletje, weliswaar zoals alle spelletjes een doodernstig spelletje, maar een spelletje en het spelen is spannender dan het winnen, zelfs als we alleen maar spelen om te winnen. We zijn altijd met onze zeer beperkte woordenschat de omringende werkelijkheid in mallen aan het duwen waar die niet in past. Met andere woorden: we zijn voortdurend aan het vertalen, we lopen voortdurend tegen vertaalproblemen op. Hoe zeg je wat je voelt? Hoe zeg je wat, sowieso en tout court? En geven mijn woorden dat wel goed weer?

Ja, zegt deze bewuste theorie: vertalen is de oerbezigheid van de mens en daarmee het enige echte oudste beroep van de wereld. Vanuit het zogeheten 'mentalese', oftewel in goed Nederlands, de 'mentaal', de taal waarin de gedachten in het hoofd spreken, in de taal der woorden die dienen ter communicatie met jezelf en met anderen. We denken niet in taal, dus spreken, schrijven of gebaren, en ook lezen is al vertalen. De mens is niet het spelende of het sprekende of het huilende of het politieke dier, maar het dier dat vertaalt, zei de Vlaamse Joyce-geleerde Geert Lernout, tijdens een Literaire Vertaaldag in Utrecht (15 december 2006). En als we leren spreken, leren we vertalen, zei de Mexicaanse schrijver Octavio Paz hem voor.

Niet alleen uit het filosofische feit dat we de vertaaldaad als een van de oudste activiteiten van de mens kunnen beschouwen, maar ook uit het simpele economische feit dat bijvoorbeeld in Nederland en Vlaanderen vijftig procent van de literatuur uit vertaalde literatuur bestaat, blijkt wel dat vertalen meer is dan een noodzakelijk kwaad voor mensen die een vreemde taal niet machtig zijn. Wij zijn immers allen Vertalianen. Welkom in Vertalië waar de citroenen tot in de hemel groeien!

In theorie tenminste. Hoe zit het met de praktijk? Want je kunt natuurlijk ook zeggen: dat is allemaal mooi en aardig, dat hoogdravende en vergalopperende getheoretiseer, maar kán dat eigenlijk wel, in concreto, iets omzetten van de ene taal in de andere, gaat er dan niet te veel verloren? En helemaal in dat rochelende en ruftende Nederlands, dat hotseklotserige houtenklazenboerenklompentaaltje van ons, onder en boven de grote riolen!?

Fritz Senn, de grootste levende Joyce-geleerde zei het ooit zo, tijdens een workshop in Zürich, gewijd aan het vertalen van Joyce: "Translation consists in optimizing rivalling incompatibilities." Oftewel, vrij vertaald: vertalen is het optimaliseren van rivaliserende incompatibiliteiten. Oftewel, nog vrijer vertaald: we moeten roeien met de riemen die ons zijn afgenomen. Oftewel, logisch voltrokken: vertalen is niet: $\mathrm{x}=\mathrm{y}, \operatorname{maar} \mathrm{x}+\mathrm{y}=\mathrm{z}$. 


\section{De praktijk}

Theoretische luchtfietserij is mooi, maar op een gegeven moment moet je toch weer de vloer op.

De werkvloer, welteverstaan. Of, omdat het in dit stuk gaat over mijn eigen bescheiden ervaring als toneelvertaler, toch weer wel de vloer, het podium, de planken, het theater.

Hét TheAter! De laatste plek waar de vergankelijkheid tot kunst verheven is. THEATER! Waar het eeuwige $n u$, het nunc stans, de eindeloze melodie van het eindeloze moment gevierd wordt. Waar het onzichtbare zichtbaar wordt gemaakt. Waar de verbeelding een beroep doet op de fantasie. Waar grote en kleine ideeën tastbaar en zichtbaar worden. THEATER! Waar het gevaar van de mislukking woont, in het kolenhok in de tuin. Waar elke beweging een nieuw gevoel oproept. Waar verveling onmiddellijk gevolgd kan worden door ontroering en ontroering door slapstick. Waar filosofie in een clownsnummer zit en een mop in logica. THEATER! Waar het hooggeëerde publiek komt om iets te ervaren waarvan het tot dan toe slechts het vermoeden kon hebben dat het bestond. Een beeld. Een geluid. Een tekst. Een gebaar. Een stilte. En altijd een andere, een nieuwe herinnering. THEATER! Ongrijpbaar, vrij! In een wereld die steeds meer vastlegt, die alles wil beheersen, die steeds minder stilstaat, ergens waar dan ook bij, in een wereld die steeds minder in magie gelooft en steeds meer in consumptie, in een wereld waarin steeds minder publieke ruimte is en de mens steeds eenzamer wordt. In die wereld gaat THEATER de godsgruwelijke leegte en de leemte opvullen. En daarom hebben we NIEUWE vORMEN nodig! Een nieuwe vorm, een nieuw verhaal, een nieuw geluid! Dát theater dus.

En als de oerbezigheid van de mens, als het woord ergens vlees wordt, als taal ergens recht voor onze ogen, waar we bij zijn, waar we bij zitten, omgezet wordt, als het ware vertaald wordt in beweging, gebaar, emotie, dan is het wel in dat theater, op het toneel. Immers: toneel is praten, afgewisseld door stilte. Als er alleen stilte is, spreken we van mime. Als er alleen gepraat wordt, is er sprake van kakofonie. Alles is in principe vertaalbaar, dus ook de laatste twee categorieën, maar uit praktische overwegingen zullen we ons beperken tot de eerste vorm van toneel.

De tamelijk drukke, manifest-achtige, typografisch licht overspannen, bijna kakofonische voorvorige alinea, voor een deel ontleend aan een zeer hedendaags en eigentijds manifest van het zeer hedendaagse en eigentijdse aanstormende Rotterdamse theatercollectief Urland, is bijvoorbeeld afkomstig uit een vertaling van De Meeuw van Tsjechov, ook wel' $n$ Meeuw of Een Meeuw, of, misschien beter nog, 
sterker, korter en bondiger, Meeuw genoemd (het Russisch laat al die mogelijkheden open).

De legendarische vertaler Charles B. Timmer vertaalde deze passage zo - aan het woord is de jonge, aanstormende toneelschrijver Kostja: "Wat we nodig hebben zijn nieuwe vormen. Een nieuwe stijl en als die er niet is, dan maar liever helemaal geen toneel. Kijkt op zijn horloge" (Tsjechow 1956). Dat is toch ... heel wat anders? Jazeker. Maar de vertaler van dienst, schrijver dezes, zag in die paar zinnen een klaroenstoet voor het futurisme, dat in Rusland pas vijftien jaar na de première van De Meeuw zou losbarsten, iets wat Tsjechov niet kon weten of kennen, misschien hooguit voorvoelde, met zijn snorharen als antennes geprikt in datgene wat er in zijn tijd in de lucht hing. Het gaat hier, eigenlijk, om de eeuwenoude vraag of je naar de geest of naar de letter moet vertalen. Als ze moesten kiezen, zouden de meeste schrijvers zeggen: naar de geest, natuurlijk! Je moet niet alleen vertalen wat er staat, maar ook wat er niet staat, in het eloquente wit tussen de regels en achter en voor de woorden.

Vertalers zouden meer moeten schrijven, en schrijvers zouden meer moeten vertalen. (Tip 0.) Niet voor niets noemde Stefan Zweig vertalen ooit

de beste vorm voor een jonge schrijver om dieper en creatiever inzicht te krijgen in het wezen van zijn eigen taal. (...) Juist doordat elke vreemde taal in zijn persoonlijke wendingen problemen creëert voor de vertaling, roept hij expressieve krachten op die anders niet gebruikt zouden worden, en deze strijd om de vreemde taal onvermoeid het meest eigene af te dwingen en de eigen taal te noodzaken tot hetzelfde plastische vermogen heeft voor mij altijd een speciale vorm van artistiek plezier betekend. Omdat deze stille en eigenlijk ondankbare arbeid geduld en uithoudingsvermogen eiste, deugden die ik op het gymnasium door lichtzinnigheid en eigenwijsheid niet had opgedaan, werd ze mij bijzonder dierbaar; want in deze bescheiden bezigheid, het overdragen van kunstwerken van hoog niveau, ervoer ik voor de eerste keer de zekerheid dat ik iets werkelijk zinvols deed, iets wat mijn bestaan rechtvaardigde. (Zweig 2016)

Bij het overdragen van toneelteksten (van welk niveau dan ook) gaat het nooit om de tekst alleen, maar ook om de context, en soms zelfs, zoals in het geval van Meeuw, om de post-context, waaraan de tekst mogelijk zelf een bijdrage heeft geleverd. Dit geldt natuurlijk voor alle vertalingen, maar bij toneel is het zo nodig nog acuter en urgenter, omdat er na de vertaling nóg een vertaalslag wordt gemaakt door de regisseur, het gezelschap, de acteurs voor wie de vertaling wordt gemaakt. Waarna het publiek de 
grote vertaalslag naar het hier en nu mag maken. Elke link die gemaakt kan worden naar het eeuwige nu van de voorstelling die voor onze ogen en oren plaatsvindt is dan welkom. 'Actualiseren' kan banale vormen aannemen (de spreekwoordelijke Hamlet op gympies, Romeo en Julia in een abattoir, Elckerlijc bij de Lidl), maar is eigenlijk niet meer (of minder) dan een aspect van de fictie die elke vertaling is: Hamlet sprak geen Nederlands. En hij dacht ook niet in het Nederlands. Dat schept, niet alleen in de taal, vrijheid en mogelijkheden. Net als de andere 'contrainte' die bij het vertalen voor toneel hoort: er worden weinig of geen toneelvertalingen gemaakt zonder concrete opdracht en voorstelling in het vooruitzicht. Het is met andere woorden in de eerste plaats een praktische aangelegenheid, geen zuivere, literaire koffie.

De vertaling moet wel tegen een stootje kunnen, want er komt veel alledaagse smerigheid bij kijken, bij zo'n voorstelling. Acteurs die bepaalde zinnen niet 'uit hun strot' kunnen krijgen, omdat ze niet 'lekker bekken'; regisseurs die hele scènes schrappen of 'in beeldtaal' willen oplossen; literaire hoogstandjes die sneuvelen omdat ze 'de vaart' uit de voorstelling halen of omdat er een liedje moet worden gezongen of een dansje gemaakt of gewoon omdat het anders een te lange zit wordt; publiek dat in slaap valt of begint te zieken. En de vertaler moet (net als de toneelschrijver trouwens) ook tegen een stootje kunnen: als hij een voorstelling bijwoont waar hij bij betrokken is, moet hij in elk geval opgewassen zijn tegen het gevoel en de ervaring dat hij er als auteur bij zou zitten terwijl een zaal met mensen zijn boek aan het lezen is - met dit verschil dat er niet alleen op het podium in het hoofd van de lezer, maar ook op het concrete podium iets moet gebeuren met de tekst, iets even mysterieus als tastbaars, om de dode letters tot leven te wekken.

Letters kunnen we lezen, spelers, de 'fantomen' op de planken, kunnen we zien, maar het grote snijpunt op zintuiglijk gebied is toch wel het gehoor. Alle goeie schrijvers schrijven met hun oren, zei Anthony Burgess, en dat schept verplichtingen voor de vertaler, zeker voor de vertaler van toneel. Hoe klinkt het? Hoe loopt het? Kan hetzelfde auditieve effect van de brontekst bereikt worden in de omzetting? Hoe praten mensen eigenlijk? Welke clichés zijn gangbaar, hoe nauw luistert de stembuiging van de haat, van de verliefdheid, waar begint men te stamelen of te fluisteren, wat is de klank van de rochel in doodsnood?

Tip 1, voor schrijvers in het algemeen, en voor toneelvertalers in het bijzonder is dus: hou je oren open voor het geruis van het gebabbel van alledag, het geroezemoes, het geruzie, de stem des volks, de stem van het hart, monologen, dialogen, hardop 
uitgesproken gedachten, terzijdes, kreten, het koor van stemmen, Stemmen van onder, stemmen van boven, stemmen van binnen en stemmen van buiten. ${ }^{1}$

Bij 'klassieke' toneelteksten doet het merkwaardige feit zich voor dat die levende taal bijna altijd in een mal van vormvastheid (rijm, metrum, stijlfiguren) is gegoten, maar ook hier geldt dat deze beperking ons tot vrijheden kan dwingen. En ook hier kunnen we van de nood van de vertaler een deugd maken. Een soortgelijke ervaring heb je bij bepaalde genres die een zekere mate van vormvastheid hebben, zoals poëzie en liedjes. De enige vertaling van een gedicht is een nieuw gedicht, zei Gerrit Komrij al. En voor liedjes geldt mutatis mutandis hetzelfde: als je een liedje vertaalt, moet je het wel kunnen zingen. Anders kun je het net zo goed laten. Als je rijm en ritme wil behouden, en in die genres wil je dat, gaat er onherroepelijk wat verloren. Maar misschien kun je er ook wel wat bij winnen. Je wordt als het ware met zachte hand een bepaalde kant opgestuurd waar je nooit naartoe was gegaan als je kon blijven spartelen in de mer à boire, de plastic soep van de ongebonden vrijblijvendheid. (Geldt ook voor schrijven trouwens: een vaste vorm helpt om de motor draaiende te houden.) Neem bijvoorbeeld onze oudste toneeltekst, Elckerlijck, uit 1495, geheel opgetrokken uit strak rappend rijmend Middelnederlands:

\section{ELCKERLIJC}

God danc u mijn vrienden vercoren

Ick claghe u met droevigher herten mijn ghevaernis

Dat ic ontboden bin alsoot claer is

Een verre pelgrimagie te gaen

Daer nemmermeer en is wederkeeren aen

Daer moet ic rekeninge doen die swaer is

Voer den heere diet al openbaer is

MAGHE

Waer af moetti rekenninghe doen

\section{ELCKERLIJC}

Van mijnen wercken om cort sermoen

Hoe ic hier mijnen tijt heb versleten

Op aertrijc ende met sonden verbeten

1 Zie hoofdstuk 2.5. 
Ende wat ic al heb bedreven

Den tijt gheleent ende niet ghegheven.

Hier wilt mede gaen dat u Godt will lonen

Ende helpt mi mijn rekeninghe verschoonen

So sal te minder werden mijn seer

Waarvan een hedendaagse vertaler-bewerker, wederom schrijver dezes, het volgende heeft gebrouwen:

DE IEDEREEN

Goddank heb ik jullie tot mijn echte vrienden uitverkoren!

Laat mij jullie kond doen van mijn droevig wedervaren,

Dat ik ontboden ben, als het ware,

Een verre tocht te entameren

Waar ik nimmermeer van kan wederkeren

Daar moet ik mijn balans gaan overleggen, in het openbare, Aan de Natuur, om mezelf nader te verklaren.

DE FAMILIE

Wat is dat voor balans die jij moet overleggen?

DE IEDEREEN

Van mijn gedrag, om het heel in 't kort te zeggen:

Hoe ik hier mijn tijd heb verknoeid

En mij bij leven en welzijn alleen met onzin heb vermoeid,

Wat ik allemaal aan voosheid heb bedreven,

In de tijd die mij geleend was, niet gegeven.

Alsjeblieft, ga met me mee, als reisgenoten, ik zou het klasse

Vinden als jullie me hielpen mijn boekhouding wit te wassen,

Want mijn incasseringsvermogen zit aan zijn limiet.

De grootste verandering is dat Onze-Lieve-Heer alias Godt het veld heeft moeten ruimen voor Moeder Natuur, maar verder is de strekking dezelfde gebleven, met behoud van het onverbiddelijke rijm dat, misschien ooit uitgevonden voor de maximale memorabiliteit, zeg maar de onthoudbaarheid van de tekst met behulp van vaste aanknopingspunten, extra muziek geeft aan die teneur. Hetzelfde geldt voor 
de blanke verzen van Shakespeare: geschreven op de menselijke hartenklop, om de ademhaling van de acteurs te vergemakkelijken, zijn ze onlosmakelijk verbonden met de zeggingskracht van de tekst.

Zeg nou zelf:

Zij dacht natuurlijk dat zij alleen was, zuchtte diep en riep uit: 'Wee mij!' Romeo was opgetogen dat hij haar hoorde spreken en hij zei zacht zonder dat zij het kon horen: 'O spreek nog eens, schitterende engel, want zo zie ik u daar verschijnen boven mijn hoofd, als een gevleugelde boodschapper uit de hemel waar stervelingen nauwelijks naar durven kijken.' Onbewust van het feit dat zij werd gehoord en vol van de nieuwe liefde die het feest haar die avond had gebracht, riep zij de naam van haar geliefde, niet wetend dat hij vlak bij haar stond: 'O Romeo, Romeo! Waarom ben je juist Romeo? Verloochen je vader, en weiger je naam ter wille van mij; of als je dat niet kunt, wees dan toch mijn eigen geliefde en ik zal niet langer een Capulet zijn.' Na deze aanmoedigende woorden stond Romeo op het punt te spreken, maar hij verlangde nog meer te horen; en de jonkvrouw ging inderdaad door met haar hartstochtelijke alleenspraak. Soms verweet zij Romeo dat hij Romeo was en een Montague; zij wilde dat hij een andere naam had of deze gehate naam zou afleggen. In plaats van die naam kon hij dan haar nemen. Nu kon Romeo niet langer stil blijven en hij nam het gesprek op alsof het persoonlijk tot hem gericht was geweest. Hij zei haar dat zij hem dan maar Liefde moest noemen, of welke naam zij maar mooi vond, want hij wilde nu niet langer Romeo heten, indien deze naam haar mishaagde. (Lamb 1969)

Klinkt toch heel anders dan:

JULIA

O God.

ROMEO

Ze spreekt.

Spreek nog eens, engel, die zo helder schittert

Vannacht, daar boven mij, even glorieus

Als de vleugels van een bode uit de hemel

In de verbaasde wit gedraaide ogen 
Van stervelingen die haast achterover vallen

Als hij op uitgeblazen wolken zit

En weg zeilt op de boezem van de lucht.

JULIA

O, Romeo, Romeo, hoezo ben jij Romeo?

Ontken je vader en verwerp je naam,

Maar wil je niet, verklaar me dan je liefde

En dan ben ik geen Capuletti meer.

ROMEO

Hoor ik nog meer of zal ik zelf spreken?

JULIA

Het is alleen je naam die mij vijandig is.

Jij bent jezelf, ook al ben je geen Montecchi.

Wat is Montecchi dan? Geen hand en ook geen voet,

Geen arm en geen gezicht, geen enkel deel

Waaruit een man bestaat. O, wees een andere naam!

What's in a name? Wat wij een roosje noemen,

Zou even geurig ruiken als het anders heette;

Dus Romeo zou, als hij niet Romeo heette,

Net zo volmaakt zijn als hij is, als hij

Die naam niet had. Dus Romeo, loos je naam,

En neem, voor iets wat geen deel uitmaakt van je,

Geen naam, maar mij aan.

ROMEO

Ik neem je op je woord.

Noem mij maar liefste en je hebt me omgedoopt.

Voor wie ik liefheb wil ik geen Romeo meer heten. (Shakespeare 2016)

Hetzelfde geldt, wederom mutandis mutandis, voor de volgende passage, toevalligerwijs ook een balkonscène, uit het grotendeels in berijmde alexandrijnen geschreven Cyrano de Bergerac (1897), niet alleen het meest gespeelde stuk, maar zo ongeveer ook de laatste vormvaste toneelhit uit de theatergeschiedenis: 
CYRANO onder het balkon; tegen Christian:

Goed. Geen luide stem opzetten.

ROXANE

Nee, u weet niet wat praten is. Ga!

CHRISTIAN

Alstublieft!

ROXANE

Nee, $\mathrm{u}$ houdt niet meer van me!

CHRISTIAN krijgtz'n woorden door Cyrano ingefluisterd

Niet 'meer' van u houden?

U doet mij onrecht ... Ik hou ... wél steeds 'meer' van u!

ROXANE wilde het raam alweer sluiten

Dat klinkt niet slecht!

CHRISTIAN ingefluisterd door Cyrano

Een krijsend kind, dat is mijn liefde;

't Wordt in mijn bange hart gewiegd en groeit als kool!

ROXANE komt het balkon op

Niet slecht! Maar als uw liefde echt zo'n krijsend kind is,

Waarom hebt $\mathrm{u}$ het dan niet in de wieg gesmoord?

CHRISTIAN ingefluisterd door Cyrano

Dat heb ik geprobeerd, mevrouw, maar ... het bleek zinloos:

Die ... jonggeborene is'n kleine ... Hercules.

ROXANE steunt met haar ellebogen op het balkon

Dat is veel beter! Maar waarom praat u met horten

En stoten? Drupt uw inspiratie zo traag door? 
CYRANO trekt Christian onder het balkon en glipt op diens plaats

Sst! Dit wordt te gecompliceerd!

Dat wordt het inderdaad. En dat komt waarschijnlijk vooral omdat deze vertaler, Laurens Spoor, zich niets van het rijm heeft aangetrokken. Van dwingend rijmende alexandrijnen heeft hij een soort quasi-vrij vers proberen te maken en daarmee heeft hij het rijm dus gereduceerd tot overbodige franje. Dat het dat niet is, moge hopelijk blijken uit deze vertaling van dezelde passage, van de hand van schrijver dezes:

CYRANO onder het balkon, tegen Christian:

Goed. Goed. Bijna fluisteren.

ROXANE

Je praat beroerd. Ga weg!

CHRISTIAN

Ik smeek je, wil je luisteren?

ROXANE

Nee! Als je niet meer van me houdt!

CHRISTIAN gesouffleerd door Cyrano

Bij God de Heer!

En dat terwijl ... ik niet ... niet meer ... van jou hou ... maar juist meer!

ROXANE wilde net het raam dicht doen, maar stopt daarmee

Hé! Dat klinkt al beter!

CHRISTIAN weer gesouffleerd

Want ... mijn liefde groeit ... de dreumes ... zo wreed ... zo iel ...

Gewiegd in 't schommelwiegje ... van mijn ... rusteloze ziel!

ROXANE komt naar voren op het balkon

Da's beter! - maar, omdat hij wreed is, ben je toch getikt, Als je die liefde niet meteen, al in de wieg verstikt? 
CHRISTIAN nog steeds gesouffleerd

Dat heb ik ... geprobeerd ... maar ... dat was geen succes:

De ... baby is, Madame, een kleine ... Hercules!

ROXANE

Da's beter!

CHRISTIAN nog steeds gesouffleerd

... Speels ... heeft hij de slang ... van Overmoed

Gewurgd ... en toen ... de slang van ... Twijfel.

ROXANE met haar ellebogen steunend op het balkon

Heel erg goed!

Maar zeg eens, Christian, waarom spreek je zo met horten

En stoten? 't Lijkt je wel aan fantasie te schorten ...

CYRANO trekt Christian onder het balkon en neemt zijn plaats in

Stil! Dit wordt haast ondoenlijk ...

\section{De rest is stilte}

En voor je het weet, zit je in de twintigste eeuw, de tijd van de versplintering, van ego's en botten, van de regelen der kunst en de vormvastheid, de tijd van de centrifugale krachten, het centrum houdt het niet meer et cetera. Een van de stukken waarin dit verklankt werd is meteen ook een van de langste toneelstukken ooit, met duizenden personages, 208 scènes en een epiloog, de 'apocalyptische allegorie' getiteld De laatste dagen der mensheid van de Weense satiricus en pacifist-polemist Karl Kraus. Het speelt zich af tijdens de Eerste Wereldoorlog en de auteur heeft vooral zijn oor te luisteren gelegd: deze oorlog speelt zich niet af aan het front, maar op straat, in cafés, restaurants, in huiskamers, met op de achtergrond steeds het kanongebulder van de pers. Bij wijze van voorbeeld en sfeertekening, het openingssalvo van het Voorspel:

Wenen. Ringbaan. Ringbaanpromenade. De Sirk-hoek. Een zomerse zondagavond.

Drukte en bedrijvigheid. Er vormen zich groepen. 
EEN KRANTENVENTER

Extra-edietsiiiie - ! Troonopvolga vermoord! Da dada gaärresteerd!

EEN RINGBAANBEZOEKER (tegen zijn vrouw)

Goddank geen jood.

ZIJN VROUW

Kom naar huis. (Zij trekt hem weg.)

TWEEDE KRANTENVENTER

Extra-edietsiiiie - ! Neue Freie Presse! Het ploedpad van Serajevo! Da dada een Servia!

EEN OFFICIER

Gegroet Powolny! Noh, wat zeggie d'rvan? Gajemee naar de Gartenbau?

TWEEDE OFFICIER (met wandelstok)

Hoe kom je d'rbij? 's Gsloten!

DE EERSTE (onthutst)

Gsloten?

EEN DERDE

Uitgsloten!

DE TWEEDE

'k Zeg't je toch!

DE EERSTE

Noh, wat zeggie d'rvan?

DE TWEEDE

Nah, dan ganeme toch naar de Hopfner. 
DE EERSTE

Vanzelfsprekend - maar ik bedoel, wat zeggie d'rvan, van de politiek, jij ben toch op de hoogte -

DE TWEEDE

Weetje, dan ganeme toch (zwaait met zijn wandelstok) - een peutje reuring - hemaal niet slecht $\hat{u}-k a n$ hemaal geen kwaad - hookxte tijd -

DE EERSTE

Je bemme toch ook een vrolijke frans. Weetje, als d'r eentje is die met z'n gat in de lucht springen, dan isset Fallota, jeweetwel die -

EEN VIERDE (komt er lachend bij staan)

Gegroet Nowotny, gegroet Pokorny, gegroet Powolny, zeg's - jij ben toch politiek onderlegd, noh, wat zeggie d'rvan?

DE TWEEDE

Weetje, dat schoelje zitter zellef achter, zo simpel isset.

DE DERDE

Weetje - zeker weten.

DE VIERDE

Helemaal mijn idee - gisteren heb ik me toch een partij gebamboucheerd - !

Hebbie de prent van Schönpflug gzien, 'n kanjer!

We horen verschillende taaleigens tegen elkaar opbieden: de straattaal van de krantenventers, het brallerige militaire taaltje van de officieren en het algemeen beschaafd van het keurige joodse echtpaar, oorspronkelijk allemaal in de bijbehorende dialectische variant van het Oostenrijkse Duits. Verderop komen we nog onder anderen Hongaarse, Berlijnse, Tsjechische en Jiddische accenten tegen. Als vertaler kan je natuurlijk gewoon doen alsof je neus bloedt, en het zo vertalen alsof er gewoon Algemeen Beschaafd Duits stond, maar dan gaat er toch meer verloren dan je wint. Goed - het wordt er misschien iets begrijpelijker van, maar dat weegt niet op tegen het verlies van de sfeer, het hart van het stuk. 
Met andere woorden: je moet er wel wat mee doen. Over het vertalen van Joyce zei de al eerder geciteerde Fritz Senn: elke zin is een gebeurtenis. Dat effect moet een vertaling ook zien te bereiken. En professor Kris Peeters uit Antwerpen beaamde dat: "Het gaat niet om oog voor particuliere woorden en uitdrukkingen, maar om oor voor de muziek", om het behoud van de "materiaal-hybriditeit in de uiteindelijke (centrifugale) taalvorm" - niet de letter is van belang, maar de geest van de brontekst, niet de zinsstructuur van het Nederlands, maar de (joyceaanse) ritmes en structuren, niet de woordelijke tekst, maar de ervaring.

Niet dat de betekeniskant er niet toe doet - het moet wel kloppen natuurlijk, maar dat is net zo'n basisvereiste als kennis van het alfabet. Als vertaler doe je het namelijk nooit goed. Het is nooit goed of het deugt niet. Of het is te vrij. Of het is te letterlijk. Of het is gewoon fout. Dat je pasta al dente niet moet vertalen met tandpasta is evident. Een goed woordenboek doet wonderen. Maar een vertaler is geen woordenboek en een vertaling is geen verklarende woordenlijst bij het origineel. Geen uitleg. Een vertaling moet idealiter hier en nu hetzelfde op de lezer overkomen als het origineel overkwam op de lezer toen en daar. Je wil hetzelfde effect, je wil het voelen, en niet alleen maar snappen. Je kan alles uitleggen in een vertaling, maar als de schrijver het zo gewild had, dan had hij het zo wel geschreven. (En die schrijvers zijn er ook, maar dat is een ander verhaal.) Het gaat, met andere woorden, niet om Nederlands tout court, maar om joyceaans Nederlands, krausiaans Nederlands, shakespeareaans Nederlands, met behoud van particulariteiten en fijnmazigheden van de stem van de auteur.

Die unieke stem moet je als vertaler zien te vinden. Helemaal als het gaat om een toneeltekst, want die wordt (als het goed is) ook letterlijk, fysiek, echt, in the flesh, gehoord. Kortom: doe waar de tekst om vraagt - want juist dat luisteren dwingt tot vrijheid, tot het vinden van de eigen stem, maar dan anders. Oftewel: $\mathrm{x}+\mathrm{y}=\mathrm{z}$. Oftewel: van iets hetzelfde maken. Dat is het streven. (Tip 2.) 


\section{Bibliografie}

Diesthemius, Petrus. Den spyeghel der saligheyt van Elckerlijc/De spiegel van de verlichting van de Iedereen. Vertaald en bewerkt door Erik Bindervoet. Amsterdam: De Harmonie, 2016.

Kraus, Karl. De laatste dagen der mensheid. Vertaald door Erik Bindervoet \& Robbert-Jan Henkes. Amsterdam: De Harmonie, 2008.

Lamb, Charles en Mary. Sprookjes en vertellingen naar Shakespeare. Vertaald door H.I. Onnes-de Groot. Amsterdam/Brussel: Agon Elsevier, 1969.

Lernout, Geert. "Sommige van mijn beste vrienden zijn vertaalwetenschappers." Filter 14:2 (2007), p. 16-21.

Paz, Octavio. Traducción: Literatura y Literalidad. Barcelona: Tusquets, 1971.

Peeters, Kris. “Ulysses, Ulysses, Ulixes: ‘Wat de hel?’” Filter 20:1 (2013), p. 48-51.

Rostand, Edmond. Cyrano de Bergerac. Vertaald door Erik Bindervoet. Amsterdam: De Nieuwe Toneelbibliotheek, 2018.

Rostand, Edmond. Cyrano de Bergerac. Vertaald door Laurens Spoor. Amsterdam: Bert Bakker, 2003. Sallis, John. On Translation. Bloomington: Indiana University Press, 2002.

Shakespeare, William. Romeo \& Julia. Vertaald door Erik Bindervoet. Amsterdam: De Nieuwe Toneelbibliotheek, 2016.

Tsjechov, Anton. Meeuw. Bewerkt door Erik Bindervoet \& Ingejan Ligthart Schenk. Amsterdam: De Nieuwe Toneelbibliotheek, 2018.

Tsjechow, Anton. De Meeuw. In: Verzamelde Werken 6. Vertaald door Charles B. Timmer. Amsterdam: Van Oorschot, 1956.

Zweig, Stefan. De wereld van gisteren. Vertaald door Willem van Toorn. Amsterdam: Arbeiderspers, 2016/1990. 


\title{
3.4. \\ Denken in veelvoud: \\ het vertalen van filosofische teksten
}

\author{
Jeanne Holierhoek
}

Filosofische teksten zijn er in allerlei soorten en maten. Iemand als René Descartes bijvoorbeeld zet een veelomvattend systeem op waarin uiteenlopende zaken aan de orde komen: het menselijk lichaam, de weersomstandigheden, geometrie en bovenal een filosofische methode. Citaten staan er in zijn teksten nauwelijks; Descartes is filosofisch geschoold maar baseert zijn bevindingen voornamelijk op eigen denkwerk, dat hem ertoe brengt zichzelf te ontdoen van alle onzekerheden totdat hij uitkomt bij de enige zekerheid die hem rest: de twijfel. Een heel ander soort filosoof, uit een heel andere tijd ook, is Michel Foucault. Hij bestudeerde de geschiedenis van de denksystemen en analyseerde daartoe stapels documenten en tal van boeken, speurend naar wat hij aanduidt als het 'discours' van een bepaalde periode. Als derde filosoof - filosoof, psychiater en essayist - noem ik Frantz Fanon, die schrijft vanuit persoonlijke ervaringen en op een veel emotionelere toon: zich inspirerend op de dialectiek van Hegel en op psychoanalytici als Adler en Anna Freud, onderzoekt hij in Peau noire, masques blancs (1952/2015) de relatie tussen zwarte en witte mensen. Om zijn redeneringen kracht bij te zetten, citeert hij even gemakkelijk uit de poëzie van Aimé Césaire als uit Hegels Fenomenologie van de geest (1807).

Wat betekent al die variatie voor het vertalen van filosofische teksten? Valt er eigenlijk wel iets algemeens te zeggen over wat deze vertaalsector onderscheidt van bijvoorbeeld het vertalen van literatuur? Ik noemde Descartes, Foucault en Fanon omdat ik ervaring heb opgedaan met het vertalen van hun werk (Descartes 2011, Foucault 2018, Fanon 2018). Waarschijnlijk is 'het vertalen van filosofische teksten' een te breed begrip om je er gespecialiseerd in te mogen noemen. Iedere nieuwe tekst vergt steeds weer opnieuw dat je je verdiept in het denken van de specifieke auteur. De filosofie kent immers vele stromingen. Een geschoold filosoof kan bijvoorbeeld goed thuis zijn in de fenomenologie, in de Angelsaksische taalfilosofie, in Plato, in 
Aristoteles, maar hij zal zich nog behoorlijk moeten inlezen alvorens een deconstructivistische of heideggeriaanse tekst te kunnen doorgronden. En andersom.

Vertalers zijn veelal kortstondige specialisten. Ze krijgen gevarieerde opdrachten aangeboden en reizen van stroming naar stroming, van eeuw naar eeuw. Met als gevolg dat ikzelf me soms weer uitvoerig in mijn aantekeningen van jaren geleden moet verdiepen als iemand me namens een groep geïnteresseerden vraagt: "Wil je ons iets komen vertellen over Montesquieu, Bergson, Michel Serres, Sartre? Je hebt immers zijn werk vertaald, dus je zult wel een deskundige zijn." De deskundigheid van vertalers ligt vooral op het gebied van de taal. Korte tijd was ik gespecialiseerd in het denken én in het taalgebruik van een specifieke filosoof, maar ik ben allang weer bezig met een ander boek.

In de hiernavolgende opsomming van vertaalproblemen zal ik zwaar leunen op mijn eigen ervaring met verschillende boeken, geschreven in verschillende stijlen. Toch wil ik ook proberen iets algemeens over het vertalen van filosofische werken te zeggen. ${ }^{1}$ De voorbeelden zullen ontleend zijn aan Franse teksten vertaald in het Nederlands.

\section{Interpreteren}

Voordat een filosofische tekst zinnig kan worden vertaald, moet er uitvoerig worden geïnterpreteerd. Filosofie vertalen zonder te begrijpen wat er staat, dat is onmogelijk. Wie in arren moede een ondoorgrondelijke zin woord voor woord gaat vertalen, die schuift het probleem door naar de lezers en maakt het waarschijnlijk nog groter. Want ook letterlijk vertalen is een vorm van interpreteren. En moet reconnaître worden vertaald als erkennen of als herkennen? Wat wordt bedoeld met homme? De mens in het algemeen, of alleen de man? Kan investissement worden begrepen in de economische betekenis van investeren, of wordt ermee gedoeld op de bezetting van Freud? En justice? Gerechtigheid, rechtvaardigheid? Staat raison gezien de context voor rede, redelijkheid, verstand? Welke betekenis schuilt er achter het participe présent: is er sprake van een causale, een concessieve of een temporele relatie met de hoofdzin?

Is de eerste versie van een vertaling eenmaal klaar, dan moet in het volgende stadium weer opnieuw worden geïnterpreteerd, zin voor zin. Oppervlakkig nalezen om te kijken of er spelfouten zijn, hinderlijke woordherhalingen en ambiguïteiten,

$1 \quad$ Zie ook hoofdstuk 3.5. 
is dan niet genoeg. Vaak heb je als 'kortstondige specialist' tijdens het werken aan de eerste versie veel boeken om de tekst heen gelezen en weet je al heel wat meer dan bij de aanvang van het project. Ook groeit je inzicht dankzij het trage tempo dat eigen is aan het vertalen. Het is een heerlijke gewaarwording als het geschrevene steeds transparanter wordt, maar het inzicht moet steeds weer opnieuw, in elke nieuwe fase van het vertaalproces, worden veroverd.

In het stadium van de tweede of derde versie van de vertaling komen de meelezers in zicht, de echte specialisten, de filosofen met inhoudelijke kennis van het denken van de auteur. Uitgeverij Boom, mijn belangrijkste opdrachtgeefster, weet meestal wel deskundige meelezers voor me te vinden. Vertalen wordt op die manier ook een veel minder eenzaam beroep dan niet-vertalers nogal eens veronderstellen. Ik denk met veel plezier terug aan de gesprekken die ik met 'mijn' specialisten heb mogen voeren. Soms hadden ze de vorm van privécolleges in mijn eigen huiskamer, soms waren het bredere discussies in commissieverband op de uitgeverij, met de redacteur erbij en met de persklaarmaakster, opdat iedereen optimaal vertrouwd kon raken met de vertaling. Natuurlijk, er bestaan geannoteerde uitgaven van het werk van de klassieke filosofen, er zijn toelichtingen over geschreven. Toch gaan bezorgers en commentatoren soms stilzwijgend voorbij aan onduidelijkheden op het microniveau waarop vertalers juist het drukste in de weer zijn. Ook mijn meelezende specialisten bleken soms nog niet eerder tot dat niveau te zijn afgedaald. Meer dan eens reageerden ze in de trant van: ik dacht het hele boek uit mijn hoofd te kennen en nu weet ik toch even niet wat dat woord betekent, of hoe die zin moet worden geïnterpreteerd. Het maakt de samenwerking leerzaam voor beide partijen: de filosofen tillen de vertaler op naar grotere gehelen, de vertaler trekt ze naar de details, en gezamenlijk komen ze tot een helder begrip.

\section{Terminologie}

Onontbeerlijk is ook de hulp van specialisten waar het gaat om de vertaling van de terminologie. De filosofie is een omvangrijk bouwwerk waarin men de weg kan vinden aan de hand van herkenbare termen, die als signalen fungeren. 'Onderbouw' en 'bovenbouw', 'categorische imperatief', 'heldere en welonderscheiden ideeën': uitdrukkingen die ons meteen in de wereld van respectievelijk Marx, Kant en Descartes brengen. Wie als niet-gespecialiseerde vertaler nieuwe woorden gaat creëren voor termen die ook in de wereld van Nederlandse filosofen al uitgekristalliseerd 
zijn, brengt de lezers in verwarring en haalt zich hun argwaan op de hals. Lezers met een beetje kennis van zaken gaan zich afvragen of de vertaling in het algemeen dan eigenlijk wel betrouwbaar is. In Zwarte huid, witte maskers (2018), geschreven door Frantz Fanon, staan nogal wat hegeliaanse en psychoanalytische termen, die herkenbaar moesten worden vertaald; daarvoor reikten mijn kennis en mijn bibliotheek gelukkig nog ver genoeg, maar met de fenomenologische term expérience vécue ging ik bijna in de fout; nog net op tijd diende zich via google de vaste uitdrukking geleefde ervaring aan. Bij het vertalen van de terminologie van Foucault in Geschiedenis van de seksualiteit (2018) had ik hulp nodig. Henk Oosterling, meelezer en deskundige, gaf aanwijzingen over het vertalen van typische Foucault-termen als discours, généalogie, archéologie, alsook over het vertalen van termen die specifiek waren voor dit ene boek: désir, plaisir, sexe, sexualité, aphrodisia. Bovendien voegde Oosterling aan de vertaling een glossarium toe waarin de termen in hun onderling verband werden geplaatst. Zo krijgt de Nederlandse lezer die begint bij het glossarium, het in zekere zin gemakkelijker dan de Franse, aan wie Foucault bijvoorbeeld pas na enkele honderden pagina's uitlegt wat voor hem precies het verschil is tussen sexe en sexualité; de auteur heeft beide termen dan al menigmaal gebruikt.

\section{Vertalen, verduidelijken, bewerken?}

Het is verleidelijk om de tekst van een filosoof enigszins te verduidelijken. Je hebt al vertalend moeizame interpretatie-inspanningen geleverd, je begrijpt eindelijk precies wat de auteur bedoelt en je wilt je lezers zo graag van dienst zijn door de boodschap wat transparanter aan hen voor te leggen. Want, zo wordt wel gezegd, van filosofische teksten is de boodschap immers belangrijker dan de vorm? Veel filosofen zijn immers geen grote literaire talenten? Waarom dan niet een beetje gladgestreken en opgeleukt? - Maar de zaak ligt genuanceerder. Vaak gaan inhoud en vorm gelijk op, is de stijl in uiteenlopende gradaties verbonden met de inhoud. Michel Foucault ontvouwt zijn redeneringen in veelal lange zinnen, in brede alinea's die het denkproces in zijn hoofd tamelijk nauwkeurig lijken te volgen. Heel kenmerkend voor hem is dat hij eerst schrijft wat iets níet is, om dan uit te komen bij hoe het volgens hem wél is. Ik pluk wat willekeurige voorbeelden uit het begin van deel 1 van Geschiedenis van de seksualiteit, met door mij aangebrachte cursiveringen: "Ik wil dus niet beweren dat in de kapitalistische en burgerlijke samenlevingen (...)" - "Dat ik deze punten van twijfel formuleer, is dus niet zozeer (...)" - "Vandaar dat de 
essentiële vraag niet zozeer is (...)" - "Voor alle duidelijkheid: ik wil niet beweren (...)". Voortdurend is hij in gesprek met denkbeeldige tegenstanders. Dat hij zich herneemt, preciseert en afbakent, zich afzet tegen andere opvattingen, benadrukt wat iets níet is, blijkt ook uit het volgende citaat:

Ik werd gedreven door een heel simpel motief, dat hopelijk voor sommigen al genoeg is, en dat motief is nieuwsgierigheid, althans de enige vorm van nieuwsgierigheid die het verdient met de nodige volharding te worden beoefend. Niet die welke probeert naar zich toe te trekken wat mensen horen te kennen, maar die welke het mogelijk maakt je van jezelf te ontdoen. Wat is een verbeten speurtocht naar het weten waard als het uitsluitend leidt tot het stapelen van kennis, zonder dat er verwarring ontstaat bij het kennende individu? (Foucault 2018: 172)

Zo'n alinea moet ook in de vertaling breed blijven uitwaaieren, de zinnen mogen niet in stukjes worden gehakt om het lezen te vergemakkelijken. Soms voeg ik een sturend woordje toe als daarom, immers, toch, of ik schrap juist een te nadrukkelijk donc, mais, en effet. Zo staat in het volgende citaat een toegevoegd $d u s$ als een bescheiden poging tot extra transparantie:

Tot degenen die menen dat jezelf moeite geven, beginnen en opnieuw beginnen, proberen, je vergissen, alles weer omwerken en dan nog kans zien om bij iedere stap te aarzelen, tot degenen dus die menen dat werken onder voorbehoud en in onzekerheid gelijkstaat aan opgeven, kan ik zeggen dat ze van een andere planeet komen dan ik. (Foucault 2018: 172)

Een uitspraak vol retorische Schwung, en alweer voor een deel een debat met denkbeeldige opponenten. Wie zich realiseert dat deze en vele andere gecompliceerde zinnen zijn geschreven in de tijd van vóór de digitale tekstverwerking, krijgt des te meer bewondering voor het stilistische talent van de auteur, wordt des te terughoudender met het ombouwen van zinsconstructies.

Maar de vertaalstijl die je kiest is zoals al opgemerkt afhankelijk van de stijl van het boek. Eerder vertaalde ik Naissance de la biopolitique (1979) van dezelfde Foucault, een gestroomlijnde weergave van de colleges die hij over dat thema gaf in het Collège de France (Foucault 2013). Bij die gelegenheid heb ik me wat meer vrijheid veroorloofd, want dat was een andere taal: met stopwoorden, herhalingen en nietszeggende omwegen die als een soort denkpauzes fungeerden. 
Ergens tussen trouw aan de tekst en drang om te verduidelijken zullen vertalers een middenweg moeten zien te vinden. Een extra complicerend element is het verschil in algemene stijl tussen het Frans en het Nederlands. Het is bekend uit de verhandelingen over stilistiek: dankzij het feit dat de Franse lezer zich het onderscheid tussen mannelijke en vrouwelijke zelfstandig naamwoorden scherp(er) bewust is, beschikt het Frans over uitvoeriger verwijsmogelijkheden, hoeft het niet steeds het zelfstandig naamwoord waarnaar wordt verwezen te herhalen; het beschikt ook over een lenig tegenwoordig deelwoord, het participe présent, en kan het daardoor stellen met een geringere aantal bijzinnen en minder voegwoorden; de volgorde in de Franse zin is strakker dan die in het Nederlands, dat gemakkelijker kan 'husselen' met zinsdelen; het Frans ruimt een grotere plaats in voor het substantief dan het Nederlands voor het zelfstandig naamwoord, waardoor het zwaartepunt van de boodschap vaak verschuift van het nominale Frans naar het verbale Nederlands; er is een verschil in dosering tussen onderschikking en nevenschikking. Deze en nog andere verschillen vergen dat er in de vertaling een evenwicht wordt gevonden tussen de specifieke stijl van de auteur, de algemene stijl van de brontaal in vergelijking met die van de doeltaal, en het verlangen van de vertaler om nu en dan iets te verduidelijken - een verlangen dat flink in bedwang moet worden gehouden.

Peau noire, masques blancs, het essay van Fanon, is weer totaal anders van stijl. Een blik op de typografie maakt het al meteen duidelijk: niet de compacte, dichtgevulde pagina's van Foucault maar ultrakorte alinea's, soms niet langer dan een of twee zinnen. Korte zinnen ook, nu en dan niets dan een emotionele kreet. Het zal te maken hebben met het feit dat Fanon schreef vanuit zijn persoonlijke, vaak negatieve ervaringen als zwarte man, maar ik zie er ook de invloed in van het feit dat hij zijn boeken dicteerde aan zijn vrouw. Het verloop van zijn redeneringen is nogal springerig, vaak wekt de tekst de indruk dat hij iets wel heeft gedacht maar al dicterend alweer verder is in zijn gedachtegang. Van de lezers wordt verwacht dat ze tussen de bondige alinea's allerlei schakels aanbrengen. In de vertaling moet dat zo blijven.

Een ander punt is het gebruik van wetenschappelijke termen. Fanon was arts en psychiater en hij wil ofwel goed laten merken dat hij zijn vak beheerst, ofwel hij beseft niet dat termen als systolische druk, affectief erethisme, fissura calcinara en integumentum vaktermen zijn. In het Franse origineel staan dezelfde specialistische termen, al zijn er ook in die taal toegankelijker alternatieven voorhanden. Ik heb deze termen in het Nederlands niet versimpeld omdat ze mijns inziens horen bij de stijl van Fanon. 


\section{Wat te doen met citaten?}

Descartes verwerkte in zijn eigen teksten vrijwel geen citaten van andere auteurs; zoals reeds opgemerkt haalde hij de inspiratie voor met name zijn puur filosofische boeken uit zijn eigen brein. Zijn werk is lastig te vertalen, maar niet omdat je daarin steeds op citaten van andere auteurs stuit. Er zijn echter ook filosofen die uitvoerig putten uit de werken van hun voorgangers en uit allerlei andere documenten, van notariële akten tot poëzie. Ze citeren dan uit het Franse origineel of uit Franse vertalingen van Griekse, Latijnse, Duitse, Engelse originelen. Een vertaling van een vertaling geldt in vertalerskringen als iets wat dient te worden vermeden, en terecht, want elke vertaling is een interpretatie. ${ }^{2}$ Hier begint het te wringen en te schuren. Enerzijds wil een vertaler zijn lezers de gelegenheid geven verder te lezen rondom de Nederlandse vertalingen van de citaten; lezers moeten andere boeken erbij kunnen pakken die mogelijkerwijs hun interesse hebben gewekt en daartoe moet het citaat bij voorkeur snel kunnen worden teruggevonden. Anderzijds past de bestaande Nederlandse vertaling van een bepaald citaat vaak slecht in de redeneerlijn van de auteur. Of - om het nog ingewikkelder te maken - de ene Nederlandse vertaling van bijvoorbeeld Plato gaat een heel andere kant uit dan de andere. Dit vraagt om schipperen. Het blijkt altijd nuttig om op zoek te gaan naar het origineel of naar de Nederlandse vertaling van een citaat, en het citaat uit het te vertalen boek ernaast te leggen. Voor Zwarte huid, witte maskers bijvoorbeeld was het een geluk dat ik Psychologie de la colonisation (1950) van Octave Mannoni er nog eens bij nam, want daarin stond een zeer wezenlijk niet dat in de door Fanon geciteerde zin een aantal keren ontbrak. Het is natuurlijk een wezenlijk verschil of er beweerd wordt dat 'de Europese beschaving en haar meest vooraanstaande vertegenwoordigers verantwoordelijk zijn voor het koloniale racisme' of dat ze juist niet daarvoor verantwoordelijk zijn. Door de springerige, hermetische, soms ironische stijl van Peau noire, masques blancs duurde het even voordat ik begreep dat er iets niet klopte (Fanon 1952/2015: 88, noot 1). Zo zijn er andere raadselachtige citaten die dwingen tot nader onderzoek. In deel 1 van Histoire de la sexualité, bijna ter afsluiting, citeert Foucault uit The Plumed Serpent (1926) van D.H. Lawrence: "Tout est sexe" (Foucault 1976: 207). In het Engelse origineel staat: "This is sex." Dat is een opvallend verschil, vooral als zo'n citaat wordt opgevoerd in het afsluitende, samenvattende gedeelte van een boek over seksualiteit. De Nederlandse vertaling

2 Zie hoofdstuk 1.4. 
van The Plumed Serpent volgt het origineel: "Dat is seks." Foucault citeert nogal eens slordig, maar hier blijkt hij getrouw de - slordige - Franse vertaling van het Engelse origineel te hebben gevolgd. Blijft de vraag of voor hem inderdaad geldt dat 'alles seks is', want dit spoort eigenlijk niet met de strekking van zijn algemene betoog.

Deze citatenproblematiek veroorzaakt altijd vertalersverdriet, omdat een rechtlijnige strategie moeilijk valt uit te stippelen. Sluit een Frans citaat van bijvoorbeeld Aristoteles goed aan op de Nederlandse vertaling, dan neem ik het fragment uit de Nederlandse vertaling over, inclusief dus de Nederlandse terminologie. Wijkt de Nederlandse Aristoteles op die plaats te veel af van het Franse citaat, dan vertaal ik het zelf uit het Frans. Het vergeten niet heb ik stilzwijgend ingelast in het citaat van Mannoni dat Fanon had opgenomen in Zwarte huid, witte maskers. Aan "Alles is seks" heb ik een 'noot van de vertaler' toegevoegd (Foucault 2018: 157). Wordt er geciteerd uit de Bijbel, dan probeer ik me te beperken tot een van de vele vertalingen die in het Nederlands beschikbaar zijn - al lukt dat ook niet altijd, en al citeert bijvoorbeeld Foucault zelf uit verschillende Franse Bijbelvertalingen.

In de imposante vertaling van Sartres L'être et le néant (1943) - Het zijn en het niet (Sartre 2003) - volgt vertaler Frans de Haan een andere strategie, die hij toelicht in het Voorwoord van de vertaler (Sartre 2003: 11 e.v.). Ook voor een dergelijke strategie is - in de context van deze specifieke vertaling - veel te zeggen. Frans de Haan schrijft dat hij zich niet "heeft gewaagd aan aanpassingen van zijn [Sartres] interpretaties van de al dan niet correct door hem geciteerde auteurs. Sartres tekst is Sartres tekst" (ibid.). De vertaler kiest dan ook voor een eigen vertaling van de door Sartre gebruikte heideggeriaanse termen, en niet voor de terminologie die Mark Wildschut via vertalingen in het Nederlands heeft geïntroduceerd en die hier min of meer de standaard zijn geworden. In zijn plausibele argumentatie stelt De Haan dat Sartre Heidegger heeft geherinterpreteerd; daar past volgens hem een nieuwe Nederlandse terminologie bij. Het zijn en het niet bevat jammer genoeg geen glossarium, maar wel weer een instructieve inleiding van Ger Groot. Uit die inleiding komt trouwens naar voren dat salaud, in zekere zin een door Sartre in de filosofie geïntroduceerde term, nog niet in een eenheidsvertaling is uitgemond. Ger Groot vertaalt het als hufters, ooit las ik de vertaling fatsoensrakkers. In Zwarte huid, witte maskers heb ik salauds onvertaald gelaten en er een omschrijving aan toegevoegd: 'verstarde mensen met kant-en-klare opvattingen'. Dat is niet bepaald een term die pakkend genoeg is om te worden gecanoniseerd, maar misschien wordt salaud in het Nederlands nog eens in onvertaalde vorm een begrip, net als de term discours die door Foucault in een heel specifieke betekenis wordt gehanteerd. 


\section{Teksten van vroeger en moderne taboes}

Het filosofisch bouwwerk eist dat de grondteksten van de filosofie beschikbaar zijn en blijven. En passant stuit je dan wel op formuleringen waarvoor de moderne mens erg gevoelig is geworden. Zo liet de mij dierbare Montesquieu, de man met de grote tolerantie en de brede visie, zich laatdunkend uit over Joden, met name over hun in zijn ogen nauwe relatie met geld. Hij had trouwens ook niet veel op met Hollanders - 'een traag en geldbelust volk' - maar dat is vanuit het hedendaagse perspectief dan toch weer gemakkelijker te accepteren dan een sneer over Joden en hun zogenaamde inhaligheid. Moeilijker was het antwoord op de vraag hoe nègre te vertalen, een woord dat in Peau noire, masques blancs talloze malen voorkomt. Sinds de jaren zestig heeft het zich in toenemende mate ontwikkeld tot een taboewoord, tot het onuitsprekelijke $\mathrm{N}$-woord. In zijn nawoord bij Niet door water maar door vuur van James Baldwin (2018: 161 e.v.) legt vertaler Harm Damsma uit waarom hij het betreurt dat uitgever De Geus koos voor het inmiddels gangbare zwart; de vertaling $z w a r t$ voor nègre werd de vertaler in feite opgelegd. Ik kan in deze kwestie een eind met Damsma meegaan wanneer hij betoogt dat

Baldwins veelvuldige gebruik van het woord "Negro" in The Fire Next Time (gemiddeld één keer per bladzijde dus) een te opvallend stilistisch kenmerk is om over het hoofd gezien te worden en alleen al om die reden niet door vertalers mag worden genegeerd. Bovendien is het historisch gezien een relevant gegeven, omdat het de ophanden zijnde omslag in taalgebruik markeert. (...) De schrijver in de Nederlandse weergave van zijn verhandeling woorden in de mond leggen die hij destijds onmogelijk gebruikt kan hebben leek mij dan ook geen optie.

Damsma meende dat deze argumenten voldoende waren, maar De Geus verwoordt in het colofon een andere opvatting: "Middels deze keuzes [de uiteindelijke keuze van de uitgever: wit in plaats van blank voor white, zwart in plaats van neger voor negro] hebben we geprobeerd recht te doen aan de auteur in de taal van het Nederlands van nu, met inclusiviteit als uitgangspunt. Vertaler en uitgever verschillen hierover van mening."

Ook in Peau noire, masques blancs een boek uit 1952, wisselen noir en nègre elkaar af. Uitgeverij Octavo en de vertaalster hadden op dit punt eigenlijk geen keus: de erfgenamen van Fanon, zonder wier toestemming de vertaling er niet mocht komen, stelden als een van hun voorwaarden dat noir consequent zou worden vertaald als 
$z w a r t$ en nègre als neger; een politiek correct woordgebruik zou volgens hen alleen maar verhullend werken en de gewelddadige associaties van het woord nègre afdekken. De erfgenamen wilden niet dat er een nawoord aan de vertaling werd toegevoegd en dat was wel enigszins frustrerend.

Overigens vertaalde ik enkele jaren geleden - samen met Katrien Vandenberghe - Critique de la raison nègre, een boek uit 2013 over de problematiek van zwart en wit, geschreven door Achille Mbembe (Mbembe 2015). Kritiek van de zwarte rede is sowieso een mooie titel, dus daarin kon het woord nègre onvertaald blijven. In het boek zelf gebruikt Mbembe Nègre (met hoofdletter) heel vaak als een soort geuzennaam en in die zin heb ik het steeds vertaald als Neger, ook met een hoofdletter. Protesten achteraf zouden me waarschijnlijk hebben bereikt, maar er kwamen geen boze brieven, dus de lezers hadden er kennelijk vrede mee. Vertalers blijven over het algemeen onzichtbaar, ze krijgen zelden lovende fanmail, maar er komen soms wel reacties als een lezer zich ergert aan een auteur of aan wat er in een boek staat. "Was die schrijver niet fout in de oorlog?" - "Mag zo'n jonge auteur wel fictie schrijven over een zwaarbeladen thema als de holocaust?" - "De hoofdpersoon van die roman is een pedofiel, bah!" In zulke gevallen krijgen vertalers nogal eens onaangename brieven, of worden ze ter verantwoording geroepen op een literaire borrel waar de tongen losgaan. Zo wordt het vertalersvak niet alleen minder eenzaam, maar ook minder saai dan vaak door buitenstaanders wordt gedacht.

\section{Ter afsluiting}

Algemene tips over het vertalen van filosofische teksten zijn kennelijk moeilijk te geven. Dit was meer een relaas van persoonlijke ervaringen, zij het misschien gevarieerd genoeg om toch nog leerzaam te kunnen zijn. Wie het vertalen van literatuur inruilt voor het vertalen van filosofie - ook dit is een persoonlijke ervaring - verliest niets aan stilistische uitdagingen. Mijn bewondering voor Foucault met zijn gecompliceerde, onberispelijk tot een eind gevoerde zinnen groeit alleen maar naarmate ik langer met zijn werk bezig ben. In en achter die zinnen is zijn persoon nooit ver weg. Een persoonlijke toon vinden we ook bij Descartes, die in Over de methode jeugdherinneringen ophaalt ("Ik was nog jong toen men mij naar school stuurde") en vertelt hoe hij in Duitsland werd overvallen door de winter en daar, in zijn 'stoof', de grondbeginselen van zijn wijsgerig systeem uitdacht (Descartes 2011: 71). De stijl is verbazingwekkend levendig voor een auteur uit de 
zeventiende eeuw. Feller en levendiger nog is de stijl van Fanon, met zijn elliptische uitroepen, zijn retorische verontwaardiging, de gaten die de lezer zelf moet opvullen en een filosofische argumentatie waarin een scala aan emoties doorklinkt. Het moge duidelijk zijn: filosofie vertalen is niet alleen denken in veelvoud, het vergt ook dat er wordt gewerkt met een veelvoud aan taalmiddelen.

\section{Bibliografie}

Baldwin, James. Niet door water maar door vuur. Vertaald door Harm Damsma. Amsterdam: De Geus, 2018.

Descartes, René. Bibliotheek Descartes, Band 3. Vertaald door Jeanne Holierhoek. Amsterdam: Boom, 2011.

Fanon, Frantz. Peau noire, masques blancs. Paris: Seuil, 1952/2015.

Fanon, Frantz. Zwarte huid, witte maskers. Vertaald door Jeanne Holierhoek. Amsterdam: Octavo, 2018.

Foucault, Michel. Histoire de la sexualité I. Paris: Gallimard, 1976.

Foucault, Michel. De geboorte van de biopolitiek. Amsterdam: Boom, 2013.

Foucault, Michel. Geschiedenis van de seksualiteit. Vertaald door Jeanne Holierhoek. Amsterdam: Boom, 2018

Lawrence, D.H. De gevederde slang. Vertaald uit het Engels door H.W.J. Schaap. Amsterdam: Uitgeverij Contact, 1969.

Mannoni, Octave. Psychologie de la colonisation. Paris: Éditions du Seuil, 1950.

Mbembe, Achille. Kritiek van de zwarte rede. Vertaald door Jeanne Holierhoek en Katrien Vandenberghe. Amsterdam: Boom, 2015.

Sartre, Jean-Paul. Het zijn en het niet. Vertaald door Frans de Haan. Rotterdam: Lemniscaat, 2003. 



\title{
3.5. \\ Non-fictie vertalen
}

\author{
Jelle Noorman
}

Wat is non-fictie? Non-fictie is feitelijk een non-begrip: een woord dat verwijst naar iets wat het niet is. Het is geen fictie, dat wil zeggen, geen op verzonnen feiten berustende literatuur. Elk geschrift dat niet aan de fantasie van de auteur is ontsproten, valt automatisch onder de noemer 'non-fictie'. Het is dus een verzamelterm, een vergaarbak voor alle lectuur uit de categorie 'overige'. Het is vreemd dat er geen woord voor bestaat dat refereert aan wat het wel is, want het concept is vrij eenvoudig te definiëren: onder non-fictie worden geschriften verstaan die op de werkelijkheid berustende feiten presenteren, analyseren en/of interpreteren. Hierbij valt te denken aan:

1. praktische geschriften (catalogi, handleidingen, kookboeken, reisgidsen)

2. naslagwerken (woordenboeken, algemene of specialistische encyclopedieën)

3. educatieve en wetenschappelijke teksten (leerboeken en academische publicaties)

4. taalkundige teksten (grammatica's, spellinggidsen)

5. journalistieke teksten

6. geschiedkundige werken

7. filosofische en religieuze werken

8. (auto)biografieën

9. essays

De definitie mag dan helder zijn, maar de grens tussen fictie en non-fictie is dat niet altijd. Er is een schemergebied waarin verzonnen en feitelijke elementen naast elkaar bestaan. Historische of biografische romans kunnen bijvoorbeeld gebaseerd zijn op waargebeurde, verifieerbare feiten, terwijl als non-fictie gepresenteerde geschiedkundige werken of biografieën soms fictieve elementen bevatten, zoals verzonnen dialogen of speculaties. Ingewikkelder nog is het om te bepalen welk 
soort geschriften behoren tot de literaire non-fictie, het genre waarover het in dit hoofdstuk voornamelijk zal gaan. Het Nederlands Letterenfonds doet in het formulier waarmee vertalers een projectsubsidie voor literaire vertalingen kunnen aanvragen de volgende poging het gebied af te bakenen:

Non-fictie op het gebied van kunst- en cultuurgeschiedenis, geschiedenis, filosofie, sociologie, politiek, psychologie, theologie, muziek en letterkunde komt in beginsel voor subsidie in aanmerking als er sprake is van een literair karakter. Hierbij valt te denken aan de inzet van literaire middelen bij de behandeling van het onderwerp, zeggings- en overtuigingskracht (het gebruik van retorische procedés), de persoonlijke betrokkenheid of visie van de auteur, oorspronkelijkheid van de invalshoek en thematiek, inventiviteit en opbouw (structuur). Teksten met een wetenschappelijk, educatief of informatief karakter zoals studies, naslag- c.q. overzichtswerken en journalistieke werken die sterk aan de actualiteit gebonden zijn vallen buiten de regeling. ${ }^{1}$

Op grond van deze criteria vallen nummers 1 tot en met 4 uit bovenstaande lijst in elk geval buiten het domein van de literaire non-fictie, en moeten de overige soorten niet-fictieve werken aan een aantal voorwaarden voldoen om het predicaat 'literair' te verdienen. Uit de omschrijving valt op te maken dat hiervoor nauwelijks objectieve maatstaven gelden. Wat wordt verstaan onder literaire middelen? Hoe bepaal je de mate van zeggings- en overtuigingskracht of de persoonlijke betrokkenheid en visie van een auteur? Waaraan herken je oorspronkelijkheid en inventiviteit? Het zijn tamelijk subjectieve criteria.

Aan literaire fictie worden deze voorwaarden door het Letterenfonds niet (expliciet) gesteld, dus je zou de voorzichtige conclusie kunnen trekken dat non-fictie in elk geval qua vorm (stijl, opbouw, originaliteit) op fictie moet lijken om als literair te worden aangemerkt. Dit heeft uiteraard consequenties voor de vertaling ervan. Vertalers van literaire non-fictie zullen rekening moeten houden met de stilistische kenmerken van een tekst - iets wat bij de vertaling van bijvoorbeeld praktische of wetenschappelijke geschriften niet of veel minder het geval is. In dat opzicht is het vertalen van literaire non-fictie niet wezenlijk anders dan het vertalen van literaire fictie.

1 http://www.letterenfonds.nl/images/2017-12/aanvraagformulier-projectsubsidies-voor-literaire-vertalingen-2018.doc. 


\section{Overeenkomsten en verschillen tussen het vertalen van literaire fictie en non-fictie}

In beide gevallen is het dus zaak de toon en stijl van een tekst te respecteren en in de vertaling zo goed mogelijk over te brengen. Dit vergt de nodige souplesse en vindingrijkheid. Om dezelfde effecten te bereiken als de auteur in het oorspronkelijke werk moet de vertaler vaak enige vrijheid nemen, 'loskomen' van de tekst, oog hebben voor de verschillen tussen bron- en doeltaal wat betreft zinsbouw, woordkeuze, compactheid et cetera. Een tekst komt tot leven wanneer de vertaler aanvoelt welke sfeer, welke intentie, welk register een zin in de brontaal heeft en vervolgens de middelen van zijn of haar eigen taal gebruikt - die soms sterk afwijken van die in de brontaal - om de lezer van de vertaling dezelfde ervaring te geven als de lezer van de oorspronkelijke tekst. Dit laatste is de essentie van literair vertalen en geldt daarom ook voor het vertalen van literaire non-fictie.

Toch is non-fictie op één belangrijk punt dwingender dan fictie: de gepresenteerde feiten moeten kloppen. Er is geen sprake van een fantasiewereld maar van een verifieerbare realiteit of, in het geval van bijvoorbeeld werken over filosofische of religieuze onderwerpen, van scherp afgebakende veronderstellingen of overtuigingen. De vertaler van non-fictie krijgt per definitie te maken met namen, begrippen, concepten en data die verwijzen naar ware gebeurtenissen, bestaande personen en culturele, maatschappelijke of politieke fenomenen. Deze moeten in de vertaling uiteraard correct worden weergegeven, wat het nodige speurwerk vergt. Non-fictie vertalen betekent in de eerste plaats onderzoek doen - en het is raadzaam daarmee te beginnen voordat je de vertaalopdracht aanvaardt, om zeker te weten dat je de materie beheerst, of kunt beheersen, binnen de voor de opdracht toegewezen tijd.

\section{Informatie vergaren}

Dankzij internet is het sinds de jaren negentig voor vertalers een stuk eenvoudiger geworden om informatie te vergaren. Ze hoeven geen lange uren meer in bibliotheken door te brengen om in encyclopedieën en andere naslagwerken de Nederlandse naam van die ene tropische zangvogel in het Amazonegebied of een Middeleeuws handwapen op te zoeken. Maar het betrekkelijke gemak waarmee tegenwoordig begrippen te vinden zijn, is ook verraderlijk. 
Het eerste probleem is dat op internet niet altijd duidelijk wordt hoe betrouwbaar een bron is of welke van de eventuele gevonden vertaal- of spellingsvarianten de voorkeur geniet. Zo moest ikzelf in de vertaling van een boek over oude Chinese denkers een keuze maken uit de verschillende schrijfwijzen van hun namen. Waar de Amerikaanse auteurs de grondlegger van het taoïsme (of daoïsme) Laozi noemden en het aan hem toegeschreven werk de Dao de jing, kwam ik als Nederlandse schrijfwijze voor de wijsgeer Lao-Tse, Lao Tse, Lao Tzu, Lao Zi en Laozi tegen, en voor het werk de titels Tao Te Ching, Tao Te Tsjing, Tao Te Tjing, Tao Te King, Dao De Jing en Daodejing (Puett et al. 2016, Puett et al. 2016, vertaling). Het lag het meest voor de hand om de spelling van de auteurs te volgen, die in het Engels een vergelijkbare afweging hadden moeten maken, ware het niet dat van een groot aantal van de in hun boek genoemde klassieke teksten tamelijk succesvolle Nederlandse vertalingen waren verschenen. Het leek me voor de geïnteresseerde Nederlandstalige lezer prettiger en duidelijker als ik de daarin gehanteerde schrijfwijze overnam. Een beslissing waarbij internet me niet had kunnen helpen.

Een tweede moeilijkheid is dat de online gevonden begrippen vaak niet voldoende context bieden. Research is niet alleen maar een kwestie van de juiste woorden vinden, het gaat er ook om dat je begrijpt waarnaar ze verwijzen. Het vertalen van non-fictie brengt over het algemeen veel leeswerk met zich mee. Als je te maken krijgt met specialistische begrippen, zoals medische, technologische, psychologische, filosofische of religieuze terminologie, gaat het erom dat je ze in hun context kunt plaatsen, dat je beseft waarom de auteur deze woorden gebruikt en wat de achtergrond is van het fenomeen dat hij of zij beschrijft. Dat betekent dat je, nog voordat je zo'n passage in de tekst vertaalt, informatie over het onderwerp moet opzoeken om vertrouwd te raken met de ideeën en gebezigde termen. De op internet gevonden gegevens schieten daarbij meestal tekort, en het is dan ook raadzaam om secundaire literatuur - zoals de door de auteur in de bibliografie opgegeven werken - te raadplegen. Dergelijk aanvullend onderzoek kost tijd, maar kan uiteindelijk ook tijd besparen doordat je dan bij het vertalen al het nodige inzicht in de materie hebt en enigszins vertrouwd bent met het jargon.

\section{Voorbereiding en eventuele samenwerking}

Meer nog dan bij het vertalen van fictie is een degelijke voorbereiding aan te bevelen. Bij het lezen van de tekst en eventuele secundaire literatuur is het handig een lijst aan te leggen met begrippen die in bron- en doeltaal verschillen, maar ook met termen of 
passages die niet onmiddellijk duidelijk zijn en waarvoor vertaaloplossingen moeten worden gevonden. Het kan daarbij gaan om namen van personen of instanties, geografische aanduidingen (landen, streken, plaatsen, rivieren) en woorden die specifiek met het behandelde onderwerp te maken hebben. Zo'n lijst is zelfs onontbeerlijk in het geval van een zogenaamde co-vertaling, een vertaling die samen met een of meer andere vertalers wordt gedaan. ${ }^{2}$ Zulke samenwerkingen komen vooral vaak voor bij omvangrijke werken of titels die vanwege hun actualiteit of verwachte populariteit met spoed op de markt moeten worden gebracht. In dat geval worden ze meestal door de uitgever geïnitieerd. Soms kiezen vertalers er echter zelf voor om met een collega te werken, en er bestaan ook vaste professionele vertaalduo's.

Er kleven voor- en nadelen aan co-vertalingen. Het grootste voordeel is dat je een klankbord hebt, feedback krijgt, overleg kunt plegen. Je staat er minder alleen voor. Je kunt elkaar voor fouten behoeden. Een ander pluspunt is dat je anders naar je eigen taalgebruik gaat kijken. Zonder dat we het weten, hebben we allemaal onze eigen manier van formuleren, woorden en uitdrukkingen die we gewoon vinden of waar we de voorkeur aan geven. Bij een samenwerking worden we geconfronteerd met de taalgewoontes en vertaaloplossingen van een ander. Dat kan verfrissend en verrijkend zijn en de kwaliteit van de vertaling ten goede komen. Een eventueel nadeel is dat je zulke verschillende ideeën kunt hebben over de juiste interpretaties, woorden of formuleringen dat dit tot oeverloze discussies leidt en uiteindelijk tot compromissen die voor geen van beide vertalers de ideale oplossing vormen. Bovendien verlies je daarmee veel kostbare tijd.

Het is overigens een illusie te denken dat een co-vertaling per definitie sneller klaar is dan een vertaling die je alleen maakt. Het hangt helemaal af van de manier van samenwerken (en dus ook van de linguïstische affiniteit die de vertalers met elkaar hebben). Meestal wordt een tekst verdeeld, waarbij de ene vertaler de eerste helft doet en de andere de tweede. Er zijn ook vertalers die ervoor kiezen het werk te verdelen in even en oneven hoofdstukken, zodat ze letterlijk maar ook inhoudelijk dichter bij elkaar blijven. Weer andere doen de vertaling helemaal samen, waarbij ze allebei de hele tekst vertalen en hun versies naast elkaar leggen. Het moge duidelijk zijn dat deze aanpak de meeste tijd kost. Maar ook bij een verdeling kunnen het corrigeren van elkaars werk en de discussies die daarop volgen erg tijdrovend zijn.

$\mathrm{Bij}$ romans en fictie in het algemeen is het van groot belang dat de stijl van het origineel consequent wordt behouden en er geen opvallende verschillen ontstaan 
tussen de stukken van de individuele vertalers. Bij non-fictie ligt soms minder nadruk op de stijl en is het vooral belangrijk dat co-vertalers dezelfde terminologie hanteren. Er zijn gevallen denkbaar dat ze elkaars teksten pas in de laatste fase - bij de drukproeven - zien en dat er tussendoor alleen overlegd wordt over bepaalde centrale begrippen. Maar dit is eigenlijk alleen aanvaardbaar bij samengestelde werken, zoals verzamelde essays of artikelen, waarin toon en stijl sterk variëren.

\section{Problemen in non-fictieteksten}

Wanneer je alleen vertaalt, zul je eventuele problemen of onduidelijkheden zelf moeten oplossen. Bij fictie kan nog weleens sprake zijn van dichterlijke vrijheden die de auteur zich heeft gepermitteerd: verrassende of onwaarschijnlijke beschrijvingen, die op te vatten zijn als symboliek of stijlfiguur. Bij non-fictie, waarin feiten uit de werkelijkheid worden gepresenteerd, is daarvoor minder ruimte, en moet je als vertaler dan ook voortdurend op je hoede zijn. Er zijn twee soorten problemen waarmee je kunt worden geconfronteerd: termen en beschrijvingen die je niet goed begrijpt, zodat je twijfelt over de vertaling ervan; en mogelijke fouten die je in de tekst tegenkomt, zoals woorden, namen, jaartallen, citaten of beschrijvingen die niet lijken te kloppen.

De oplossing voor het eerste probleem is waar het bij non-fictie eigenlijk altijd om draait: onderzoek doen, informatie vergaren en meer lezen over de beschreven materie. Daarbij moet worden aangetekend dat het, wanneer je bij de eerste lezing van een te vertalen werk erg veel onduidelijk blijft, verstandig is je af te vragen of je in staat zult zijn de opdracht naar behoren en binnen de gestelde tijd te voltooien. Een professioneel vertaler moet vooral ook zijn of haar beperkingen onderkennen. Als er een halve studie voor nodig is om de bedoelingen van de auteur te doorgronden, is het waarschijnlijk geen tekst voor jou. Dit geldt in de eerste plaats voor boeken of artikelen over specialistische onderwerpen. Voor iemand met weinig natuurwetenschappelijke kennis is het bijvoorbeeld geen goed idee om Stephen Hawking te vertalen.

Voor het andere probleem - de mogelijke fouten of onvolkomenheden in een tekst - is de oplossing minder eenduidig. Ook hier begint het weer met onderzoek. Bij goede schrijvers en serieuze uitgevers mag je aannemen dat de gepresenteerde feiten gecontroleerd zijn. Het is echter een vergissing om ervan uit te gaan dat alles altijd klopt zoals het er staat. Vooral bij Engelstalige werken, waarvan de vertaling veelal 
tegelijk met of kort na de oorspronkelijke editie moet verschijnen, heb je vaak te maken met een eerste, al dan niet gecorrigeerde, drukproef. Daarin kunnen door de auteur of een corrector nog wijzigingen worden aangebracht. Maar ook in reeds gepubliceerde werken kun je op woorden, zinnen, namen of feiten stuiten die niet juist lijken.

Eenvoudige spelfouten leveren over het algemeen geen problemen op, al kunnen ook die verraderlijk zijn. In een werk dat ik moest vertalen (O'Connell 2016, 2018) was in een citaat over interneurale verbindingen in de hersenen sprake van rest time - een begrip dat ik in eerste instantie vertaalde met 'rusttijd'. Maar omdat ik niet precies begreep wat daarmee werd bedoeld en het ook om 'resttijd' zou kunnen gaan, ben ik op zoek gegaan naar het werk waaruit was geciteerd. Het woord bleek verkeerd te zijn overgenomen: er stond reset time, 'resettijd'. Het is hoe dan belangrijk om citaten te verifiëren, zeker als het gaat om vertaalde fragmenten, die niet in de moedertaal van de auteur zijn geschreven. De oorspronkelijke tekst wil daar nog weleens van afwijken.

Bij andere onduidelijkheden die op een vergissing van de auteur lijken te berusten, is het verstandig om eerst goed na te gaan of je zelf niet iets over het hoofd ziet of verkeerd hebt opgevat. Mocht je er niet uitkomen en contact opnemen met de schrijver of de uitgever, dan kun je in elk geval duidelijk uitleggen wat het probleem is. Bij kennelijke fouten kun je besluiten die voor rekening van de auteur te laten, maar dat brengt als risico met zich mee dat jij er later zelf op wordt afgerekend. Recensenten hebben de neiging (al dan niet vermeende) onvolkomenheden aan de vertaler toe te schrijven. Feiten checken is daarom bij het vertalen van non-fictie onontbeerlijk, zelfs als ze slechts terloops door de auteur worden vermeld en verder geen rol spelen in de tekst.

Zo kwam in een door mij vertaald boek over het geloof in God in verschillende culturen (Lenoir 2011, 2013) een familielid van de profeet Mohammed ter sprake: 'son oncle maternel, Abou Talib'. Dit was echter geen oom van moederskant, zoals de schrijver hier beweerde, maar een broer van Mohammeds vader.

In een ander non-fictiewerk, over afleiding in ons bestaan (Young 2008, 2014), was een hoofdstuk gewijd aan de Amerikaanse schrijver Henry James, waarin deze op het eerste gezicht cryptische zin met een citaat voorkwam: "Henry stayed in London, where he was 'far from the maddening crowd, beside these sordid sands'. Het leek vreemd dat iemand in Londen 'ver van de tierende menigte' kon zijn. En wat was dat voor 'smerige zandvlakte'? Iets verderop in de tekst stond een aanwijzing: 'he retreated to Ramsgate in London'. Blijkbaar veronderstelde de (Australische) auteur dat de kustplaats Ramsgate een Londense wijk was. Na enig speurwerk vond ik het citaat uit de eerste zin in een brief die James inderdaad vanuit Ramsgate, en niet Londen, had verstuurd. 
Maar het komt ook voor dat een bevreemdende passage zo is bedoeld door de auteur. In Religion for Atheists van Alain de Botton (2011) stuitte ik op de beschrijving van een Londense universiteit met tweehonderdduizend studenten, waarvan een nieuw gebouw kort geleden was geopend door een minister van onderwijs en een 'cousin of the Queen'. Het leken me wel erg veel studenten voor één universiteit, en bovendien kon ik geen berichten vinden over deze officiële opening. Dat laatste was noodzakelijk om erachter te komen of met de cousin een nicht of een neef van de koningin werd bedoeld. Uiteindelijk heb ik het aan de auteur gevraagd, die me vertelde dat hij geen toestemming had gekregen om de universiteit in kwestie bij naam te noemen en verzonnen details had toegevoegd om de verwijzingen naar de bestaande instantie te verdoezelen.

\section{Overleg met de auteur of uitgever}

Een laatste punt dat, gezien de noodzakelijke accuraatheid, bij non-fictie vaak een grotere rol speelt dan bij fictie is het contact met de auteur. ${ }^{3}$ Bij vragen en problemen kan het noodzakelijk zijn de schrijver te raadplegen. Dit is niet altijd mogelijk: de auteur kan al overleden zijn of geen prijs stellen op correspondentie. Soms loopt het contact via een agent of een uitgever en niet zelden duurt het (te) lang voordat er een reactie komt. In die gevallen zal er, al dan niet in overleg met een redacteur van de eigen uitgever, door de vertaler zelf een oplossing voor de kwesties moeten worden gevonden. Als een directe uitwisseling met de auteur wel mogelijk is, doet de vertaler er goed aan deze voorzichtig en respectvol te benaderen. Niet elke schrijver vindt het prettig om te worden geconfronteerd met onduidelijkheden, laat staan met vergissingen. Het hangt uiteraard van de auteur in kwestie af. Er zijn er die graag meedenken en suggesties doen - alles om een optimale vertaling mogelijk te maken. Anderen reageren terughoudender en geven summiere of onvolledige antwoorden. In de meeste gevallen is het verstandig om alleen de vragen te stellen waar je echt niet uitkomt en deze duidelijk en beknopt te verwoorden. En bij geconstateerde vergissingen van de auteur is uiteraard enige tact geboden. Maar uiteindelijk zal een serieuze schrijver altijd blij zijn met een vertaler die zich zorgvuldig en gewetensvol over zijn werk ontfermt.

3 Zie ook 1.5. 


\section{Bibliografie}

Botton, Alain de. Religion for Atheists. A non-believer's guide to the uses of religion. Londen: Hamish Hamilton, 2011.

Botton, Alain de. Religie voor atheïsten. Een heidense gebruikersgids. Vertaling Jelle Noorman. Amsterdam: Atlas, 2011.

Lenoir, Frédéric. Dieu. Parijs: Robert Laffont, 2011.

Lenoir, Frédéric. God? Vertaling Jelle Noorman. Utrecht: Ten Have, 2013.

O'Connell, Mark. To Be a Machine. New York: Doubleday, 2016.

O'Connell, Mark. De mensmachine. Vertaling Jelle Noorman. Amsterdam: Podium, 2018.

Puett, Michael, Christine Gross-Loh. The Path: What Chinese Philosophers Can Teach Us About the Good Life. New York: Simon \& Schuster, 2016.

Puett, Michael, Christine Gross-Loh. De Weg - Wat Chinese filosofen ons over het goede leven leren. Vertaling Jelle Noorman. Utrecht: Ten Have, 2016.

Young, Damon. Distraction. Melbourne: Melbourne University Press, 2008.

Young, Damon. Afgeleid. Vertaling Jelle Noorman. Utrecht: Ten Have, 2014. 



\section{6. \\ Vertalen van kinder- en jeugdliteratuur}

Goedele De Sterck

Kinder- en jeugdliteratuur in vertaling wordt binnen het literaire veld en daarbuiten vaak afgedaan als een randverschijnsel. Als ware het kinderspel. Vertalers beschouwen het als een aanloop naar het 'echte', 'grote' werk en uitgevers claimen dat het gemakkelijker en dus goedkoper is. Onderzoekers benadrukken dat vertalingen voor jonge lezers vrijer zijn omdat kinder- en jeugdboeken een ondergeschikte, marginale of perifere positie bekleden ten opzichte van volwassenenliteratuur. Of omgekeerd, dat kinder- en jeugdboeken een secundaire status hebben omdat vertalers zich meer vrijheden veroorloven. De kip of het ei.

Is vertalen van kinder- en jeugdliteratuur een randverschijnsel? Is het niet meer dan kinderspel? Gaat het gepaard met een grotere vertaalvrijheid? In dit hoofdstuk probeer ik een beeld te schetsen van de situatie van kinder- en jeugdliteratuur in vertaling waarbij het Nederlands als brontaal of doeltaal fungeert. Vanuit de overtuiging dat de dialoog tussen theorie en praktijk en tussen wetenschappers en beroepsvertalers vruchtbaar en verrijkend is, baseer ik me op enerzijds algemene opvattingen en ideeën uit de vakliteratuur (LZL 2005, Filter 2005, Noorduijn en Vanden Bosch 2016, Van Coillie en Kalla 2017, Petra-E' ${ }^{1}$ ) en anderzijds mijn ervaring als literair vertaalster. De algemene beschouwingen worden geillustreerd met voorbeelden uit de praktijk, zowel van eigen hand als van collega-vertalers (zie literatuurlijst). Het overzicht beperkt zich tot de eenentwintigste eeuw en de talen en culturen waarmee ik vertrouwd ben.

1 Zie https://petra-educationframework.eu/nl/, geraadpleegd op 10 oktober 2018 . 


\section{Enkele cijfers}

Binnen de vertalingendatabase die het Nederlands Letterenfonds in samenwerking met het Vlaams Fonds voor de Letteren bijhoudt, kan onder meer gezocht worden op 'genre'. Sinds 2000 zijn er meer dan 4300 kinder- en jeugdboeken uit het Nederlands vertaald, waarvan een vierde in het Duits, dat samen met het Frans en het Engels iets minder dan de helft van de vertalingen op zijn naam heeft staan. Om het aandeel van kinder- en jeugdboeken in het totaalaanbod van vertalingen in kaart te brengen wordt in onderstaande tabel een brede en representatieve keur aan talen weergegeven die verwante en minder verwante, centrale en perifere, gezaghebbende en minder gezaghebbende culturen vertegenwoordigen.

Het valt meteen op dat kinder- en jeugdboeken in vertaling geen geringe plaats innemen. Ze maken maar liefst 40 procent van het totaalaanbod uit. Met uitzondering van het Arabisch, het Engels en het Tsjechisch belopen ze een derde of meer van het aantal gepubliceerde literaire vertalingen, los van de regio, met Japan en China als uitschieters. Markant is ook dat de helft van deze titels prentenboeken zijn, een genre dat bijzonder in trek is in het Arabisch en het Frans maar duidelijk minder belangstelling wekt in het Tsjechisch, het Pools, het Duits en het Russisch.

Aangezien de database geen vertalingen in het Nederlands bevat, zijn we hiervoor aangewezen op elders gehanteerde statistieken, die een soortgelijke trend weerspiegelen. Afhankelijk van de bron blijkt dat kinder- en jeugdliteratuur in het Nederlandstalige gebied een derde tot bijna de helft van het totaalaanbod aan vertaalde titels bestrijkt, een volume dat in de afgelopen decennia gestaag is blijven groeien.

Voornoemde cijfers bewijzen dat kinder- en jeugdboeken in vertaling verre van marginaal zijn. Ook het aantal verkochte exemplaren mag niet onderschat worden. Prentenboeken en kinderseries gaan vlot over de toonbank, vooral wanneer er verfilmingen, video's, interactieve websites en merchandising mee gemoeid zijn. De Muizenhuis-reeks (Schaapman) ${ }^{2}$ is hiervan een sprekend voorbeeld. Ze wordt vertaald in meer dan vijfentwintig talen en is wereldwijd een groot succes. Jonge lezers (en hun ouders) hebben een ruime keuze aan knutselideeën en knuffelmuisjes en kunnen bovendien ook het levensechte decor in de Openbare Bibliotheek van Amsterdam bezoeken.

2 Schaapman, Karina. Het muizenhuis (reeks). Amsterdam: Rubinstein Publishing Bv. 
Tabel 1. Vertalingen uit het Nederlands sinds 2000 per taal en regio (centraal, zuid, noord, oost, wereld) ${ }^{3}$

\begin{tabular}{lrrrrr}
\hline Doeltaal & $\begin{array}{l}\text { Totaal- } \\
\text { aanbod } \\
\text { vertalingen }\end{array}$ & $\begin{array}{l}\text { Aantal } \\
\text { kinder-en } \\
\text { jeugdboeken }\end{array}$ & $\begin{array}{l}\text { Percentage } \\
\text { totaal- } \\
\text { aanbod }\end{array}$ & $\begin{array}{l}\text { Prenten- } \\
\text { boeken }\end{array}$ & $\begin{array}{l}\text { Percentage prentenboeken } \\
\text { t. o. v. het aanbod kinder- en } \\
\text { jeugdboeken }\end{array}$ \\
\hline Totaal & 10992 & 4349 & 39,57 & 2197 & 50,52 \\
\hline Duits & 2645 & 1035 & 39,13 & 275 & 26,57 \\
Engels & 1354 & 349 & 25,78 & 208 & 59,60 \\
Frans & 1245 & 482 & 38,71 & 356 & 73,86 \\
\hline Spaans & 670 & 263 & 39,25 & 156 & 59,32 \\
Italiaans & 523 & 157 & 30,02 & 68 & 43,31 \\
\hline Zweeds & 243 & 104 & 42,80 & 61 & 58,65 \\
Fins & 238 & 90 & 37,82 & 44 & 48,89 \\
\hline Tsjechisch & 373 & 64 & 17,16 & 13 & 20,31 \\
Pools & 192 & 65 & 33,85 & 17 & 26,15 \\
\hline Chinees & 408 & 276 & 67,65 & 166 & 60,14 \\
Japans & 381 & 255 & 66,93 & 112 & 43,92 \\
Turks & 301 & 107 & 35,55 & 46 & 42,99 \\
Afrikaans & 201 & 111 & 55,22 & 46 & 30,00 \\
Russisch & 196 & 60 & 30,61 & 18 & 82,35 \\
\hline Arabisch & 71 & 17 & 23,94 & 14 & \\
\hline & & & & & 44 \\
\hline
\end{tabular}

\section{Aard en wezen}

De vraag of het vertalen van kinder- en jeugdliteratuur wezenlijk verschilt van het vertalen van volwassenenliteratuur (en van vertalen in het algemeen) doet veel inkt vloeien, maar is voor de vertaler van ondergeschikt belang. Een vertaler vertaalt teksten en gaat daarbij in essentie steeds op dezelfde manier te werk. Hij zoomt in op de componenten van het interculturele communicatieproces. De hamvraag is keer op keer: wie schrijft wat waar en wanneer voor wie met welke intentie en op

3 Zie http://www.letterenfonds.nl/nl/vertalingendatabase, geraadpleegd op 10 oktober 2018. 
welke manier? Het antwoord vergt een tweevoudig perspectief: bron en doel. Deze dubbele analyse ligt ten grondslag aan om het even welke vertaalopdracht.

Bij het vertalen van een kinder- of jeugdboek speelt de communicatieanalyse zich grofweg af binnen de volgende grenzen: een (meestal) volwassen auteur schrijft op een bepaald moment in een bepaalde taal en cultuur en binnen een bepaalde uitgeverij een boek voor kinderen of jongeren (direct of indirect vaak ook voor ouders en opvoeders) met overwegend educatieve en/of onderhoudende en/of literaire doeleinden en hanteert daarbij specifieke tekstconventies (verhaal, strip, non-fictie, poëzie, prentenboek ...) en een eigen stijl. Heeft dit gevolgen voor de vertaling? Uiteraard. Bovenstaande analyse legt onvermijdelijk spanningen bloot die voor vertaalproblemen (kunnen) zorgen. Het is aan de vertaler om die vertaalproblemen op te sporen en op te lossen aan de hand van passende vertaalstrategieën. Er zij op gewezen dat dergelijke probleempunten per definitie deel uitmaken van het vertaalproces. Dat verloopt volgens een vast stramien en er is dus geen enkele reden om aan te nemen dat het vertalen van kinder- en jeugdliteratuur in vergelijking met andere genres kinderspel is.

Hoe groter de afstand in tijd en ruimte, hoe groter de cultuurverschillen. Die uiten zich op tal van niveaus. Zo kan er binnen het literaire veld sprake zijn van uiteenlopende opvattingen over de rol van kinder- en jeugdliteratuur of de rol van vertalingen. In een cultuur waar moraal en norm sterker doorwegen dan respect voor het oorspronkelijke werk en zijn auteur zullen vertalers meer geneigd zijn tot het uitvoeren van diepgaande ingrepen dan hun collega's in landen waar het auteursrecht een feit is en respect afdwingt. Ook genreconventies zijn vaak cultuurgebonden. In permeabele literaturen die vernieuwing van buitenaf — onder meer door vertaling - beschouwen als een verrijking van hun eigen literaire traditie, beschikken vertalers doorgaans over de nodige speelruimte om bestaande genreconventies te doorbreken, terwijl meer gesloten culturen zweren bij vervlakking en aanpassing aan de doelcode. Bovendien, hoe groter de culturele afstand, hoe groter het risico dat de doeltaallezer bepaalde referenties en connotaties mist. Dit geldt in sterke mate voor kinderen en jongeren, aangezien hun kennis en leefwereld doorgaans beperkter is dan die van de gemiddelde volwassene. Als intercultureel bemiddelaar en '(co)auteur' zal de vertaler alle middelen aanwenden om een versie aan te leveren die zoveel mogelijk van de oorspronkelijke tekst bewaart (intentie, taal, toon, sfeer, leeservaring) en tegelijkertijd voor de doelgroep even begrijpelijk, even leesbaar en even geloofwaardig is als het origineel. Nieuw maar herkenbaar. Anders maar vergelijkbaar. 
In dit verband wordt algemeen aangenomen dat vertalers van kinder- en jeugdliteratuur zich vanuit de asymmetrische relatie volwassene-kind graag aanpassen aan hun publiek en vaak kiezen voor een doeltekstgerichte, naturaliserende of domesticerende aanpak in de overtuiging dat de jonge lezer (nog) niet in staat is om de vreemde elementen te begrijpen of naar waarde te schatten en alle belang heeft bij herkenbaarheid, inleefbaarheid en puur leesplezier. Een brontekstgerichte, vervreemdende of exotiserende vertaling is daarentegen gebaseerd op de veronderstelling dat het vreemde een verrijking inhoudt en dat kinderen heus wel tegen een stootje kunnen. Wellicht is het de kunst om het midden te houden tussen deze twee uitersten. Uiteindelijk is het de auteur die de algemene toon zet voor wat zijn lezerspubliek al dan niet aankan en is het aan de vertaler om de lat even hoog te leggen in de doeltekst en elke uiting van vertaalpaternalisme te schuwen. Vanuit praktisch oogpunt kan het daarbij nuttig zijn om zich de volgende vraag te stellen: hoe zou de schrijver zich tot het doelpubliek hebben gericht?

Terwijl de auteur en zijn eigenheid een vaste waarde vormen in het vertaal- en communicatieproces (zijn naam prijkt op de kaft van het origineel én de vertaling) zijn de andere actoren onderhevig aan verandering. Dat geldt in de eerste plaats voor de uitgever en zijn strategieën. De houding ten aanzien van kinder- en jeugdliteratuur in vertaling verschilt al naargelang het profiel van de uitgeverij: zuiver commercieel, uitgesproken literair, conservatief en politiek correct... En dat profiel blijft niet per se hetzelfde bij de overgang van de broncultuur naar de doelcultuur. De vertaler wikt, maar de uitgever beschikt, al is er doorgaans wel marge voor overleg. Ook de uitgangssituatie van het lezerspubliek verandert, niet alleen van de jonge lezer zoals hierboven is aangegeven, maar ook van de volwassenen (ouders, docenten, bibliothecarissen) die 'meelezen' en de literaire smaak mee bepalen. Dit verschijnsel wordt ook wel dubbele lezersgerichtheid of meervoudige geadresseerdheid genoemd. De wensen en verwachtingen van uitgevers en meelezende volwassenen in de doelcultuur kunnen drastische gevolgen hebben voor de vertaling.

Een andere schakel in het proces is de aard van de brontekst. Ook binnen de kinder- en jeugdliteratuur is sprake van genres: narratief proza, non-fictie, poëzie, stripverhalen, prentenboeken ... De ervaring leert echter dat de vertaler in dit geval vanuit praktisch oogpunt baat heeft bij een andere onderverdeling, namelijk de mate waarin diepgaande interventie in vorm en inhoud al dan niet aanvaardbaar, vereist of wenselijk is. De variatie aan vertaalvormen, gaande van adaptatie tot vertaling in enge zin, wordt doorgaans beschouwd als een van de bijzondere kenmerken. 
Aan het ene uiterste staan de titels waarop geen auteursrechten meer rusten, met name sprookjes en klassiekers. Inhoud en vorm worden vaak zodanig bewerkt dat het niet altijd duidelijk is op welke brontekst ze teruggaan. Alles kan en mag, inclusief lokalisering (verandering van tijd en ruimte), aanpassingen van de plot (bijschrijven of weglaten), ideologische manipulatie ... Dergelijke bewerkingen komen zelden voor rekening van de vertaler en worden meestal overgelaten aan auteurs (als de literaire functie primeert) of aan pedagogen en leerkrachten (wanneer de educatieve functie de overhand heeft). Het gaat daarbij vaak niet langer om vertalingen maar om aanpassingen van eerdere vertalingen van de brontekst. Die hebben meestal tot doel om de brontekst aan te passen aan de eigentijdse taal en leefwereld.

Moderne kinder- en jeugdboeken in vertaling vallen onder het auteursrecht en bieden dus volgens de gangbare wettelijke en ethische normen en principes geen ruimte voor bewerking in bovenstaande zin. Toch kunnen ook hier ingrepen in de brontekst plaatsvinden. De mate waarin dat gebeurt is grotendeels afhankelijk van de combinatie van drie criteria: intentie van de auteur, intentie van de uitgeverij in de doelcultuur en leeftijd van de lezers. Ofschoon dankzij internet en de sociale media boekbesprekingen en aanbevelingen door kinderen geraadpleegd kunnen worden en fanvertalingen en kinderboeken door en voor kinderen aan populariteit winnen, wordt kinder- en jeugdliteratuur hoofdzakelijk geschreven, becommentarieerd, vertaald en uitgegeven door volwassenen. De functies die deze teksten vervullen kunnen in grote lijnen als volgt worden samengevat: pedagogisch-didactisch-ideologisch (kennisverruiming of waardenvorming), onderhoudend (leesplezier en vermaak) en/of literair-esthetisch (gevoel voor literatuur). Als de intentie die in de brontekst tot uiting komt samenvalt met die van de uitgever in de doelcultuur kan de vertaler eenvoudigweg de maatstaf van de auteur hanteren. Een eventueel conflict kan echter voor spanningen en ingrepen in de tekst zorgen.

Ter illustratie hiervan zoomen we even in op De voetbalgoden (Van Gemert) ${ }^{4}$, een reeks voor kinderen vanaf negen jaar waarin vermaak (avontuur en competitie) de boventoon voert. Sport, en dan vooral voetbal, is een populair thema dat jonge lezers aanspreekt. In een wereld waarin lezen steeds vaker moet wijken voor bezigheden die als boeiender en uitdagender worden ervaren is het in de eerste plaats zaak om kinderen warm te maken voor boeken in de hoop dat ze de smaak te pakken krijgen en mettertijd ook belangstelling zullen tonen voor de 'grote' literatuur. Dat is wellicht een van de redenen (samen met het te verwachten succes van een 
voetbalreeks) waarom deze titels in Spanje op de markt worden gebracht door Bruño, een toonaangevende educatieve uitgeverij die actief bijdraagt aan leeslijsten van scholen en fondsen van kinder- en jeugdbibliotheken. De afstand tussen de functie van de brontekst en de missie van de buitenlandse uitgeverij en haar 'meelezers' leidt onvermijdelijk tot een tweevoudige ingreep: de stijl wordt opgeschoond en politiek incorrecte uitingen (bijvoorbeeld racistische opmerkingen) worden afgezwakt of weggezuiverd.

Aan jeugdliteratuur (chicklit en ladlit, fantasy en science fiction, historische romans, non-fictie ...) wordt doorgaans minder gesleuteld omdat adolescenten, zoals blijkt uit termen als young adults of cross-over, veelal op één lijn worden gesteld met volwassenen. Hoe jonger het lezerspubliek en hoe lager het literaire gehalte van de brontekst en het literaire cachet van de auteur, hoe groter de kans dat de uitgever ofwel de vertaler opdraagt om in te grijpen in de tekst ofwel de vertaling achteraf zelf afstemt op zijn eigen kindbeeld. Dit is met name ook van toepassing op prentenboeken. Nederland en Vlaanderen staan bekend om hun illustratoren (bijv. Philip Hopman, Annemarie van Haeringen, Carll Cneut of Ingrid Godon) en dat heeft tot gevolg dat vele uitgeverijen bij het aankopen van buitenlandse titels afgaan op de illustraties. Precies omdat de tekst van 'secundair' belang is, wordt er vaak vrij mee omgesprongen. Een belangrijk criterium is voorleesbaarheid, zelfs al moet het verhaal daarvoor herschikt of geherformuleerd worden. Voorwaarde is evenwel dat de samenhang tussen tekst en beeld gewaarborgd blijft.

Eerder is aangetoond dat het kwantitatieve gewicht van kinder- en jeugdliteratuur in vertaling buiten kijf staat. Uit het voorgaande blijkt dat vertaalde kinder- en jeugdboeken ook in kwalitatieve termen een belangrijke rol spelen. Samen met de eigen literatuur bevorderen ze de cognitieve, psychische en sociale ontwikkeling van de jonge lezer en vormen ze een bron van leesplezier en literaire smaakvorming. Uitgevers die met behulp van de vertaler op zoek gaan naar toegevoegde waarde, naar iets 'nieuws' of 'anders' dat in het assortiment van eigen bodem ontbreekt, verruimen bovendien de blik van het lezerspubliek over de grenzen heen.

\section{Vertaalproblemen en (mogelijke) vertaaloplossingen}

Hoewel de problemen die opduiken bij het vertalen van kinder- en jeugdliteratuur en de oplossingen die door vertalers worden aangedragen ook elders voorkomen, zijn er punten die geregeld terugkeren en vaak samen optreden, al zijn ze niet per 
definitie op alle kinder- en jeugdboeken van toepassing. Een greep uit de praktijk: culturele referenties ${ }^{5}$ (eigennamen, merknamen, bestaande of fictieve begrippen, gerechten), interactie met illustraties, oraliteit (dialoog, taalregister), rijm, liedjes en klankpatronen ${ }^{6}$, humor en woordspelletjes ${ }^{7}$, meertaligheid ${ }^{8}$ (penetratie van het Engels en aanwezigheid van verschillende culturen), gespecialiseerd taalgebruik (non-fictie) ${ }^{9}$, lezersgerichtheid ...

Op macroniveau liggen communicatieanalyse en reflectie aan de basis van een empathische vertaling die zoveel mogelijk rekening houdt met alle spelers en spelelementen. Wat is het kindbeeld van de auteur? Tot welke lezers richt hij zich? Welk doel beoogt hij met zijn boek? Om wat voor soort boek gaat het? Is er sprake van genreconventies? Wat zijn de eigen stijlkenmerken van de auteur en de tekst (gemarkeerd versus ongemarkeerd taalgebruik)? Wat is hun functie? Welk doel beoogt de uitgeverij in de doelcultuur met de vertaling? Is de brontaal/-cultuur ver verwijderd van de doeltaal/-cultuur? Het antwoord op deze vragen zal de vertaler in de gelegenheid stellen eventuele problemen te ontdekken en passende vertaalstrategieën te zoeken en te hanteren: welke elementen moet/kan/wil ik behouden en hoe doe ik dat in de doeltaal?

Ongeacht de aard van de vertaalopdracht zet de vertaler op microniveau bewust of onbewust steeds dezelfde stappen: hij detecteert een probleem (wie het probleem niet ziet, kan het ook niet oplossen, met alle gevolgen van dien), bedenkt mogelijke oplossingen (creativiteit), schat de gevolgen en het effect van de verschillende strategieën in (twijfel) en maakt een keuze (beslissing). Vertalen beantwoordt niet aan vaste recepten of regels, maar aan een hoogstpersoonlijke mix van hoogstpersoonlijke keuzen. Niets is van nature juist of fout. Goed en slecht zijn relatieve begrippen. Dé perfecte oplossing bestaat niet, ook niet in kinder- en jeugdliteratuur. Belangrijk is dat elke afzonderlijke beslissing past in het geheel en aansluit bij het doel dat de vertaler met zijn vertaling nastreeft op grond van de voornoemde macroanalyse.

\footnotetext{
Zie ook 2.2.

Zie ook 2.4.

Zie ook 2.6.

Zie ook 2.5.

Zie ook 3.5.
} 


\section{Voorbeeld 1}

Dubbel Doortje (Sollie 2004) is een voorleesboek voor kinderen van drie tot zes jaar met versjes in rijmvorm die ondersteund worden door prenten. Een kleine kleuter ontdekt dat ze alles dubbel heeft, of toch niet? De titel is een vertaalprobleem op zich: alliteratie, verwijzing naar het tweevoud en naam van de hoofdpersoon, die op de cover en op verschillende illustraties in het boek staat afgebeeld maar verder niet in de tekst wordt genoemd. In de Spaanse versie, Doble Didi, blijven de drie elementen behouden en wordt de tweevoudigheid nog versterkt door de herhaling binnen de eigennaam die wordt aangepast aan de Spaanstalige kleuter. Het Franse Deux par deux giet de alliteratie en het concept van dubbelheid in een telrijmpje, maar laat de naam varen.

Bij het omzetten van de versjes zelf moet rekening gehouden worden met vorm, inhoud en illustraties. De Franse versie geeft voorrang aan het behoud van de inhoudelijke nuances ten koste van het rijmschema, terwijl in de Spaanse tekst rijm en ritme prevaleren boven de exacte weergave van de brontekst, ofschoon de onderliggende gedachte intact blijft. Twee verschillende keuzen en oplossingen die elk op hun manier recht doen aan de auteur en het boek. Onderstaand versje gaat vergezeld van een illustratie waarop een giraf met twee nekken staat afgebeeld:

Tabel 2. André Sollie, Dubbel Doortje: rijm

\begin{tabular}{|c|c|}
\hline NL & $\mathrm{FR}$ \\
\hline Ik zie plots lege plekken. & Est-ce que je suis malade? \\
\hline Waarom heb ik geen nekken? & Où est mon autre front? \\
\hline Wat stom dat ik dat nu pas merk. & J'aurais dû m'en apercevoir plus tôt. \\
\hline Wat moet ik met één achterwerk? & Un seul derrière, c'est idiot. \\
\hline \multicolumn{2}{|l|}{ ES } \\
\hline $\begin{array}{l}\text { Recorro mi cuerpo de acá para allá. } \\
\text { ¿Y mi otro cuello dónde está? } \\
\text { Quizá suene un poco grosero, } \\
\text { pero ¿qué hago yo con un solo trasero? }\end{array}$ & \\
\hline
\end{tabular}




\section{Voorbeeld 2}

Ook in Polleke (Kuijer), een reeks voor kinderen van tien tot twaalf jaar over een meisje dat het leven en zijn problemen niet uit de weg gaat, komen tal van vertaalproblemen samen: onder meer eigennamen (culturele referenties), meertaligheid (Nederlands en Spaans) en woordspelletjes.

Tabel 3. Guus Kuijer, Polleke (5 delen): eigennamen

\begin{tabular}{llll}
\hline NL & DE & FR & ES \\
\hline Polleke & Polleke & Pauline & Poleke \\
Mimoen & Mimun & Mimoun & Mimun \\
\hline
\end{tabular}

In de geraadpleegde versies worden de eigennamen aangepast aan de spelling van de doeltaal om te waarborgen dat de vertalingen voor de jonge lezer even leesbaar zijn als de brontekst. De vervanging van Polleke door Pauline blijft geloofwaardig omdat deze Franse naam ook in de broncultuur gehoord wordt en dus past in de Nederlandse context waarin het verhaal zich afspeelt. In dit geval gaat het niet om 'sprekende namen' waarvan de betekenis bepalend is voor de karakterisering van het personage. Ook wanneer dit wel het geval is worden vaak verschillende strategieën gehanteerd: de betekenisvolle achternaam van Mr. Wormwood uit Matilda (Dahl 1988) wordt vertaald in het Frans (monsieur Verdebois) en in het Nederlands (meneer Wurmhout), maar blijft behouden in het Spaans (señor Wormwood).

In deel drie krijgt Polleke er een Mexicaans klasgenootje bij. De dialogen waarin Nederlands en Spaans gemengd worden vormen een niet te onderschatten vertaalprobleem.

Tabel 4. Guus Kuijer, Het geluk komt als de donder (Polleke 3): meertaligheid

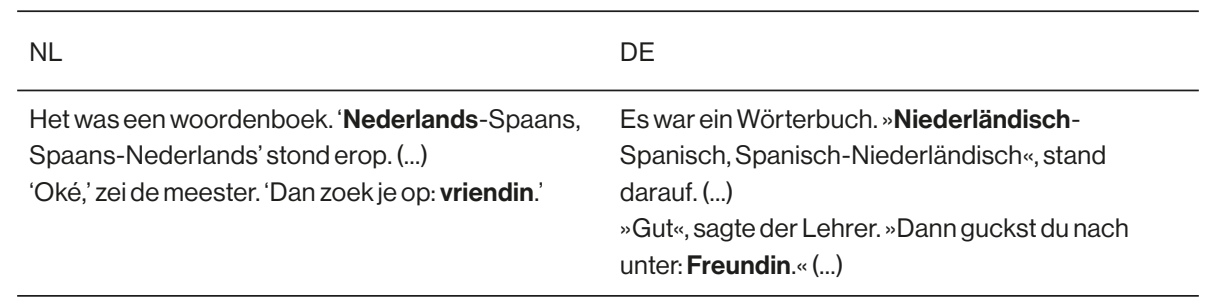




\begin{tabular}{ll}
\hline FR & ES \\
\hline $\begin{array}{l}\text { C'était un dictionnaire sur lequel était écrit: } \\
\text { «Néerlandais-Espagnol, Espagnol-Néerlandais ». }\end{array}$ & $\begin{array}{l}\text { Era un diccionario. Llevaba escrito: "Neerlandés- } \\
\text { español, español-neerlandés”. (...) } \\
\text { (...) }\end{array}$ \\
$\begin{array}{l}\text { - Muy bien - respondió el profesor-. Busca la lit l'instituteur. Vas-y, Pauline, cherchele } \\
\text { mot «amie »....) }\end{array}$ & \\
\hline
\end{tabular}

De Spaanse versie legt de lat hoog (net zoals Kuijer met zijn jonge lezers doet) en speelt zoveel mogelijk met het Nederlands en het Spaans, onder meer ook ter wille van de geloofwaardigheid. In de andere versies worden de Nederlandse woorden vertaald in de doeltaal en blijft het Spaans behouden.

Polleke zegt regelmatig 'ik word wiebel' wanneer iets haar ontroert. Het adjectief loopt als een rode draad door de reeks en maakt deel uit van het idioom van de hoofdfiguur. In de Franse versie wordt 'wiebel' op diverse manieren vertaald, zodat de functionele herhaling van de brontekst verloren gaat. In de andere twee versies blijft ze behouden.

Tabel 5. Guus Kuijer, Polleke (5 delen): 'wiebel'

\begin{tabular}{ll}
\hline NL & DE \\
\hline Er was iets in haar ogen waar ik wiebel van werd. & $\begin{array}{l}\text { In ihren Augen war etwas, wovon mir schwummrig } \\
\text { wurde. } \\
\text { Ze gaat open als een bloem. Ik word er wiebel van. } \\
\text { Sie öffnet sich wie eine Blume. Mir wird ganz } \\
\text { schwummrig davon. }\end{array}$ \\
\hline FR & ES \\
\hline $\begin{array}{l}\text { Quelque chose dans ses yeux m'a fait chavirer. } \\
\begin{array}{l}\text { On dirait qu'elle s'ouvre comme une fleur. Et ça me } \\
\text { bouleverse. }\end{array}\end{array}$ & ¿Ay, esos ojos! iCasi me derrito! \\
\hline
\end{tabular}

\section{Voorbeeld 3}

Het wonder van jou en je biljoenen bewoners (Schutten 2015), een non-fictieboek over het menselijk lichaam voor kinderen vanaf tien jaar, zorgt dan weer voor een ander vertaalprobleem. In de Germaanse talen, zoals het Nederlands en het Duits, zijn wetenschappelijke termen vaak relatief doorzichtig omdat er veel woorden uit de omgangstaal worden gebruikt. De Romaanse talen daarentegen staan bol van de Griekse en Latijnse benamingen. Bijvoorbeeld 'buikvlies' en 'waterstof' versus 
'peritoneo' en 'hidrógeno' in het Spaans. Schutten belooft zijn jonge lezer dat hij zijn best zal doen om de tekst zo eenvoudig mogelijk te houden en moeilijke woorden te bewaren voor de illustraties, al waarschuwt hij dat dit soms onmogelijk is. Aan 'moeilijke' Nederlandse termen voegt hij vaak een korte beschrijving of omschrijving toe. Daarmee reikt hij vertalers in Romaanse talen een oplossing uit eigen keuken aan: om te waarborgen dat de vertaling ongeveer even leesbaar blijft als voor een Nederlandstalig kind volstaat het om de strategie van de auteur vaker dan in de brontekst toe te passen.

Tabel 6. Jan Paul Schutten, Het wonder van jou en je biljoenen bewoners: vulgariserend versus gespecialiseerd taalgebruik

\begin{tabular}{ll}
\hline $\mathrm{NL}$ & $\mathrm{DE}$ \\
\hline $\begin{array}{ll}\text { Een watermolecuul bestaat bijvoorbeeld uit twee } \\
\text { waterstofatomen en een zuurstofatoom. Waterstof } \\
\text { is dus iets héél anders dan water. }\end{array}$ & $\begin{array}{l}\text { Ein Wassermolekül setzt sich aus zwei } \\
\text { Wasserstoffatomen und einem Sauerstoffatom } \\
\text { zusammen. Wasserstoff ist damit etwas } \\
\text { vollkommen anderes als Wasser. }\end{array}$ \\
\hline
\end{tabular}

ES

Por ejemplo, una molécula de agua está formada por dos átomos de hidrógeno y un átomo de oxígeno. Aunque «hidro" significa "agua» en griego antiguo, el hidrógeno y el agua son dos cosas muy distintas.

Aangezien het menselijk lichaam een universeel gegeven is en dit boek op om het even welk kind van toepassing is, kunnen lokale culturele referenties als 'Rennen springen vliegen duiken vallen opstaan en weer doorgaan' worden aangepast. Het gaat om de titel van een hoofdstuk over sport en beweging waarin de auteur verwijst naar een liedtekst van Herman van Veen (een knipoog naar de meelezende volwassene). In de Spaanse versie is gekozen voor 'Trotar, saltar y ronda', een Spaans kinderliedje waarin gesprongen en gedanst wordt. De dubbele lezersgerichtheid wordt hier even overboord gezet, maar de overige elementen blijven behouden. In de Duitse vertaling verdwijnt de connotatie en is gekozen voor een letterlijke vertaling van de denotatieve betekenis ('Rennen, springen, fliegen, tauchen, fallen, aufstehen, weitermachen'). 


\section{Voorbeeld 4}

Spreektaal in dialoogvorm is niet weg te denken uit kinder- en jeugdboeken. In onderstaand voorbeeld uit Mockingjay (Collins 2010) richt Katniss zich tot haar kat met een vraag waarin ze verwijst naar haar zusje Prim. Geloofwaardigheid is hier opnieuw een belangrijke maatstaf. Het taalgebruik moet passen bij het personage dat aan het woord is: in dit geval een zeventienjarig 'modern' meisje. Katniss personifieert de kat van haar zusje Prim ('de lelijkste kater ter wereld') en stelt hem een zeer natuurlijke en spontane vraag die kenmerkend is voor de Engelse spreektaal. Hoe wordt dit opgelost in de vertalingen?

Tabel 7. Suzanne Collins, Mockingjay: spreektaal (dialoogvorm)

\begin{tabular}{|c|c|c|}
\hline EN & $\mathrm{NL}$ & $\mathrm{DE}$ \\
\hline "Come here, boy." & 'Kom eens hier, jochie.' & "Komm her, alter Junge." \\
\hline "Want to see Prim?" I ask. & 'Wil je naar Prim?' vraag ik. & "Möchtest du Prim sehen?» \\
\hline FR & CAT & ES \\
\hline - Approche, mon vieux. & «Vine aquí, noi». & -Ven aquí, chico. \\
\hline $\begin{array}{l}\text { - Tu veux revoir Prim? je lui } \\
\text { demande. }\end{array}$ & $\begin{array}{l}\text {-Vols veure la Prim? - li } \\
\text { pregunto. }\end{array}$ & $\begin{array}{l}\text { - ¿Quieres ver a Prim?-le } \\
\text { pregunto. }\end{array}$ \\
\hline
\end{tabular}

IT

- Vieni qui, piccolo.

- Tiva di vedere Prim? -chiedo.

Het modale partikel 'eens', het informele 'jochie' en de vervanging van het letterlijke 'Wil je Prim zien?' door het idiomatische 'Wil je naar Prim?' geven aan de Nederlandse versie een frisse, jeugdige uitstraling. In de andere vertalingen leunt de vraag sterker aan bij de brontekst, terwijl de aanspreekvorm varieert van jong tot oud, van informeel tot neutraal en van liefdevol tot afstandelijk. Dit heeft tot gevolg dat de relatie tussen Katniss en het dier van vertaling tot vertaling verschilt. Alles hangt af van de interpretatie van 'boy' en het beeld dat de vertalers zich gaandeweg hebben gevormd van de kater. 


\section{Voorbeeld 5}

Bij het vertalen van jeugdboeken zijn informeel taalgebruik, straattaal en streektalen een vaak voorkomend probleem. In Kiffe kiffe demain (Guène 2004) is een vijftienjarig Frans-Marokkaans meisje aan het woord. Ze drukt zich uit in een mengtaal die gebezigd wordt door jongeren van multi-etnische voorstedelijke wijken waarin verlan, argot en vreemde invloeden herkenbaar zijn. Het taalgebruik van de vertelster weerspiegelt het hybride karakter van haar eigen identiteit en de socioculturele context waarin ze opgroeit en speelt dus een functionele rol. Uit onderstaande fragmenten blijkt dat de vertalers verschillende strategieën hebben gebruikt om respectievelijk het informele taalgebruik en de arabismen weer te geven. Het is de kunst om de connotaties over te brengen zonder dat de geloofwaardigheid in het gedrang komt. Geen lezer die aanneemt dat een Frans-Marokkaans meisje zich uitdrukt in een Nederlands, Vlaams, Spaans of Engels lokaal dialect...

Tabel 8. Faïza Guène, Kiffe kiffe demain: informeel taalgebruik

\begin{tabular}{ll}
\hline FR & NL \\
\hline $\begin{array}{l}\text { Ceux avec l'acteur beau gosse qui raconte } \\
\text { toujours un tas de trucs mythos à sa meuf, une } \\
\text { cigarette au coin du bec. }\end{array}$ & $\begin{array}{l}\text { Met in de hoofdrol een hippe gast met een peuk in } \\
\text { zijn ene mondhoek, die allerlei mooie praatjes aan } \\
\text { zijn sweetie verkoopt. }\end{array}$ \\
\hline ES & EN \\
\hline $\begin{array}{l}\text { (...) en que un actor guaperas le cuenta un montón } \\
\text { de trolas a su chorba con un cigarrillo colgado de } \\
\text { la comisura de los labios. }\end{array}$ & $\begin{array}{l}\text { The ones where the handsome actor's always telling } \\
\text { his wom his lips. }\end{array}$ \\
\hline
\end{tabular}

Terwijl de informele taalkenmerken uit de brontekst in de Nederlandse en de Spaanse vertaling worden weergegeven door informele elementen uit de doeltaal, waarbij onder meer geput wordt uit de straattaal ('sweetie') en de zigeunertaal ('chorbo'), is in de Engelse tekst elke connotatie verdwenen.

In het volgende voorbeeld liggen de verhoudingen anders. Een arabisme zoals 'walou', dat door de auteur zelf van uitleg wordt voorzien omdat het geen deel uitmaakt van de Franse woordenschat, geniet een identieke behandeling in de doeltalen. 'Bled' geldt daarentegen als een volledig ingeburgerd woord dat is opgenomen in alle gangbare Franse woordenboeken. Voor vele anderstalige lezers is dit arabisme echter even onbekend als 'walou'. In dit geval is het de Engelse vertaalster die het vreemde element behoudt en de 
bijbehorende connotaties aan het begin van de roman uiteenzet in een korte woordenlijst. In de andere twee vertalingen gaat het arabisme verloren. De Nederlandse vertaler kiest voor 'Marokko', een totum pro parte dat indirect zowel de denotatieve als de connotatieve elementen uit de brontekst weergeeft, maar geen onderscheid maakt tussen stad en platteland. De gestandaardiseerde vervanging uit de Spaanse versie roept heel andere connotaties op dan het pejoratieve 'bled': nostalgie, identificatie en waardering.

Tabel 9. Faïza Guène, Kiffe kiffe demain: arabismen

\begin{tabular}{ll}
\hline FR & NL \\
\hline Rien, walou. & Helemaal niks, waloe. \\
Le concept Taxiphone, il est made in bled. & Het idee van de Taxiphone, dat is made in Marokko. \\
\hline ES & EN \\
\hline Nada, walou. & Nothing, walou. \\
El concepto Taxiphone es made in mi tierra. & Basically, the whole Taxiphone idea is made in the BLED. \\
\hline
\end{tabular}

Uiteraard heeft het geen zin om vertalingen te beoordelen op losse voorbeelden. Net zoals de brontekst vormt de doeltekst een geheel en mogen individuele oplossingen voor functionele vertaalproblemen (soortgelijke middelen op dezelfde plaats of compensatie door soortgelijke middelen op een andere plaats of andere taalkundige middelen) niet uit hun verband worden gerukt. Idealiter zou de eindbalans dezelfde moeten zijn.

\section{De kinder- en jeugdboekenvertaler}

Vertalen is niet hetzelfde als vertaler zijn. Vertaler zijn houdt een reeks belangrijke uitdagingen en verantwoordelijkheden in. De zogenaamde secundaire status van kinder- en jeugdliteratuur leidt tot een reeks misverstanden die door de vertaler actief moeten worden bestreden. Honoraria liggen doorgaans lager en royalty's zijn niet vanzelfsprekend, ${ }^{10}$ ofschoon het vertaalproces en de moeilijkheidsgraad niet

10 Praktijken die haaks staan op punten 2 en 5 van de gedragscode van het Europese netwerk van organisaties van literair vertalers (CEATL). Zie: https://www.ceatl.eu/translators-rights/hexalogue-orcode-of-good-practice, geraadpleegd op 10 oktober 2018. - Zie ook hoofdstuk 1.1. 
wezenlijk verschillen en kinder- en jeugdboeken evengoed onder het auteursrecht vallen. Het is dan ook de taak van de vertaler om op te komen voor de zaak van de kinder- en jeugdliteratuur in vertaling, die per slot van rekening zijn eigen zaak is.

Het gaat daarbij niet uitsluitend om tarieven en royalty's, maar ook om het recht om drukproeven in te kijken en drastische ingrepen te voorkomen die de eigenheid van de auteur en de tekst op onrechtmatige wijze aantasten. Overleg met de auteur, de uitgever en de proeflezer is in dit opzicht van onschatbare waarde. Een naar vorm en inhoud 'kindgerichte' vertaling van een schrijver als Bart Moeyaert, die kinderen serieus neemt, een en al ironie is en een eigen literaire stijl hanteert, betekent een regelrechte inbreuk op het auteursrecht en op de gedragscode van de literair vertaler. ${ }^{11}$ Literaire vertalingen, met inbegrip van kinder- en jeugdboeken, zijn meer dan 'consumptiegoederen', tenzij de auteur zelf commerciële doeleinden nastreeft of zich uitdrukkelijk bereid verklaart in het buitenland te worden omgedoopt tot een commercieel schrijver in een poging om met succes eender welke grens over te steken. In dat geval heiligt het doel de middelen ...

\section{Bij wijze van besluit}

Kinder- en jeugdboeken zijn uit zowel kwantitatief als kwalitatief oogpunt bijzonder relevant. De secundaire status die ze van oudsher krijgen toegedicht is een mythe. Het is aan de actoren van het literaire veld, inclusief de vertaler, om deze mythe uit de wereld te helpen.

Vertalen van kinder- en jeugdliteratuur kent geen exclusieve problemen of oplossingen. De (literair) vertaler gaat in wezen steeds op dezelfde manier te werk. De dubbele communicatieanalyse legt de verhoudingen tussen auteur, tekst, lezer en uitgever bloot en helpt de vertaler bij het detecteren van vertaalproblemen (die zich ook elders voordoen maar in dit geval vaker en vaak samen optreden) en bij het vinden van passende vertaalstrategieën (in overeenstemming met het kindbeeld

11 Zie bijvoorbeeld Artikel 1, lid 1, van het Modelcontract voor de uitgave van een vertaling van een literair werk: "De vertaler verbindt zich tot het leveren van een naar inhoud en stijl getrouwe en onberispelijke Nederlandse vertaling rechtstreeks uit het oorspronkelijke werk."

http://www.vvl.nu/vvl/media/original/93/190612_lug_vvl_modelcontract_literaire_vertalingen_ en_toelichting.pdf, geraadpleegd op 10 oktober 2018 . Ook punt 3 van de gedragscode van bijvoorbeeld ACE Traductores (Spaanse vereniging van literair vertalers) onderstreept dit: https://ace-traductores. org/profesion/codigo-deontologico/, geraadpleegd op 10 oktober 2018. 
van de auteur). Net zoals bij andere genres zijn er moeilijkere en gemakkelijkere teksten en auteurs, maar één ding is zeker: het vertalen van kinder- en jeugdboeken is geen kinderspel.

Bronteksten die tot het publiek domein behoren kunnen ten gevolge van een haast grenzeloze adaptatie worden omgevormd tot een nieuw boek met een nieuwe auteur 'naar...', terwijl boeken met copyright naar inhoud en vorm respect voor de auteur afdwingen. Asymmetrie en dubbele lezersgerichtheid hoeven in dit opzicht geen probleem te zijn, aangezien het volstaat om zich in te leven in het kindbeeld en de intentie van de auteur (en de uitgever van deze visie in kennis te stellen).

Vertaling van literatuur in het algemeen en van kinder- en jeugdliteratuur in het bijzonder heeft onder meer tot doel om de internationale verstandhouding te bevorderen. De gegevens van de vertalingendatabase liegen er niet om. Zoals verwacht staan de buurtalen Duits, Frans en Engels aan de top. Het is echter flagrant dat bijvoorbeeld in de landen van Noord- en Oost-Europa aanzienlijk minder Nederlandstalige kinderboeken en met name prentenboeken worden vertaald dan in China en Japan. Wellicht ziet het plaatje dat ik hier heb geschetst er in grote delen van de wereld anders uit ...

\section{Primaire literatuurlijst}

Collins, Suzanne. Mockingjay (Hunger Games 3). New York: Scholastic Press, 2010.

Collins, Suzanne (vert. Maria Postema): Spotgaai (De hongerspelen 3). Amsterdam: Van Goor, 2010.

Collins, Suzanne (vert. Sylke Hachmeister en Peter Klöss). Flammender Zorn (Die Tribute von Panem 3). Hamburg: Friedrich Oetinger, 2011.

Collins, Suzanne (vert. Armand Carabén). L'ocell de la revolta (Els jocs de la fam 3 ). Barcelona: Grup 62, 2013 .

Collins, Suzanne (vert. Simona Brogli). Il canto della rivolta (Hunger Games 3). Milano: Mondadori, 2012.

Collins, Suzanne (vert. Guillaume Fournier). La révolte (Hunger Games 3). Paris: Pocket Jeunesse, 2012.

Collins, Suzanne (vert. Pilar Ramírez Tello). Sinsajo (Los juegos del hambre 3). Barcelona: RBA Libros, 2011.

Dahl, Roald. Matilda. London: Puffin Books, 1988.

Dahl, Roald (vert. Huberte Vriesendorp). Matilda. Utrecht: De Fontein, 1998.

Dahl, Roald (vert. Henri Robillot). Matilda. Paris: Gallimard Jeunesse, 1997.

Dahl, Roald (vert. Pedro Barbadillo). Matilda. Barcelona: Alfaguara, 2005.

Guène, Faïza. Kiffe kiffe demain. Paris: Hachette littératures, 2004.

Guène, Faïza (vert. Frans van Woerden). Morgen kifkif. Amsterdam: Luitingh-Sijthoff, 2005. 
Guène, Faïza (vert. Sarah Adams). Kiffe Kiffe Tomorrow. Boston: Houghton Mifflin Harcourt, 2006. Guène, Faïza (vert. Jordi Martín Lloret). Mañana será otro día. Barcelona: Salamandra, 2006 Kuijer, Guus. Het geluk komt als de donder (Polleke 3). Amsterdam: Querido, 2012.

Kuijer, Guus (vert. Sylke Hachmeister). Das Glück kommt wie ein Donnerschlag. Hamburg: Friedrich Oetinger, 2003.

Kuijer, Guus (vert. Maurice Lomré). Le bonheur surgit sans prévenir. Paris: L'école des loisirs, 2009.

Kuijer, Guus (vert. Goedele De Sterck). Poleke. La felicidad llega por sorpresa. México D.F.: Castillo, 2017.

Schutten, Jan Paul. Het wonder van jou en je biljoenen bewoners. Harlem: J. H. Gottmer, 2015.

Schutten, Jan (vert. Verena Kiefer). Der Mensch oder Das Wunder unseres Körpers und seiner Billionen Bewohner. Hildesheim: Gerstenberg, 2016.

Schutten, Jan Paul. La respuesta eres tú y tus billones de habitantes. Vertaald door Goedele De Sterck. Madrid: Maeva, 2019.

Sollie, André. Dubbel Doortje. Amsterdam: Querido, 2004.

Sollie, André (vert. Isabelle Rosselin). Deux par deux. Paris: Sarbacane, 2005.

Sollie, André (vert. Goedele De Sterck). Doble Didi. México D. F.: Fondo de Cultura Económica, 2007.

\section{Secundaire literatuurlijst}

Themanummer over kinder- en jeugdliteratuur in vertaling. Literatuur zonder leeftijd (LZL), 2005, jaargang 19 , nummer 67.

Themanummer "Hans, Pippi, Grietje en andere vertaalde kinderen." Filter 12:4 (2005).

Noorduijn, Mirjam en Veerle Vanden Bosch. Het boekenboek. 1001 onverwachte dwarsverbanden. Amsterdam: Uitgeverij Leopold, 2016.

Van Coillie, Jan en Irena Barbara Kalla (red.). Minoes, Minnie, Minu en andere katse streken. De internationale receptie van Annie M.G. Schmidts Minoes. Lage Landen Studies 8. Gent: Academia Press, 2017. 


\section{חpl IV}

Na het

vertalen 



\section{1. \\ (Zelf)revisie}

Laura van Campenhout \& Ine Willems

De revisie van een boekvertaling valt uiteen in zelfrevisie, ofwel de blik en inbreng van de vertaler zelf, en revisie door andere tekstprofessionals. Zelfrevisie is een proces dat in elk stadium van de boekvertaling speelt. Het begint en eindigt bij geïnformeerd zelfkritisch vermogen of, anders gezegd, bij de fabricage van een paar uitgekiend lek geboorde klompen om nattigheid mee aan te voelen. Die fabricage kost jaren: ze is een kwestie van (wil om te) blijven leren.

\section{Tijdens het vertalen}

\section{Zelfrevisie en blikverfrissing}

Een onverwacht voorzetsel in de brontekst, woorden of zinsneden waaraan je brein om een of andere reden blijft haken, de neiging om (significant) meer woorden te gebruiken in je vertaling dan er in de brontekst staan: het zijn allemaal signalen om terug te gaan naar de brontekst en/of op (verder) onderzoek uit te gaan. Doe dat ook vooral: je vertaling kan er alleen maar beter want treffender van worden en je breidt er je kennisreservoir mee uit, wat je in de toekomst absoluut van pas komt.

Hoe scherp je je zelfkritische vermogen aan? Allereerst door veel in bron- en doeltaal te lezen en veel naar bron- en doeltaalvarianten te luisteren, zodat je je gevoel voor toon en register ontwikkelt. Maar ook door zelf meelezer te zijn voor een collega: je opent er je ogen mee voor veelvoorkomende fouten en (eigen) blinde vlekken. Verder zijn close-readingsessies (in groepsverband en/of in je eentje), waarin je een brontekst met zijn vertaling vergelijkt en de vertaalkeuzes en het effect ervan weegt, enorm nuttig. En je kunt overwegen om je kennis op een meer 
geformaliseerde manier te verdiepen door je beroepsvaardigheden uit te breiden met die van een persklaarmaker of corrector.

Hoe blijf je nu kritisch en alert als de deadline dringt en je in korte tijd telkens hetzelfde doorleest? In de eindfase van je vertaling zul je alle middelen moeten aangrijpen om met een frisse blik naar je tekst te kunnen kijken. De hoofdstukken hardop voorlezen - of mooier nog, láten voorlezen - kan helpen. De meest voorkomende mankementen - tekst die niet soepel leest, ontsporende zinnen en incongruenties van tijd en getal - komen er onverbiddelijk mee aan het licht. Je kunt je tekst natuurlijk ook inspreken en vervolgens de opname beluisteren.

\section{Klankborden en extra ogen}

\section{Meelezer}

Kies je meelezer(s) met zorg. Meelezen wordt door collega-vertalers vaak als vriendendienst gedaan, dus met gesloten beurzen: bij een andere gelegenheid lees jij de vertaling-in-wording van die ander. Een goede meelezer, die je attendeert op blinde vlekken en meedenkt bij lastige passages, kan een ideaal klankbord zijn.

\section{Deskundige}

Vraag deskundigen om advies: leg je vertaalkwestie voor aan de psychiater, paaldanseres, hondenkenner of hangjongere die de precieze bewoordingen en uitdrukkingen kent waar je in naslagwerken vergeefs naar zult zoeken.

\section{Auteur}

Soms zal de auteur de enige zijn die een troebele passage kan toelichten. ${ }^{1}$ Overleg met de uitgever of en hoe je contact kunt opnemen. Auteurs buigen zich doorgaans met plezier over relevante vragen. Het is handig om al in een vroeg stadium contact te zoeken, dat opent de deur om later vragen te stellen.

\section{Mentor}

Ook een mentor, die je mogelijk in het kader van een ontwikkelingsbeurs of een mentoraat begeleidt, vormt een belangrijk klankbord. 


\section{Co-vertaler(s)}

Het kan voorkomen dat je in een team van twee of meer vertalers werkt ${ }^{2}$, bijvoorbeeld als tijdsdruk een rol speelt - jouw agenda of die van een collega staat de volledige boekvertaling niet toe of een bepaalde publicatiedatum is van belang - of gewoon omdat je het prettig vindt om samen te werken. Een co-vertaler deelt je belangen (een optimale vertaling en een tevreden opdrachtgever): je fungeert als elkaars klankbord bij onderhandelingen, leest en becommentarieert elkaars tekst en stemt vertaalkeuzes en spellingswijzen af. Degene die de ander(en) uitnodigt, voert in principe de onderhandelingen met de uitgeverij. Maak meteen in het begin duidelijke afspraken over planning en redactie van jullie gezamenlijke project, en bedenk dat de tijdwinst die je met een teamvertaling boekt relatief is: een deel ervan zal opgaan aan afstemming en overleg.

\section{Redacteur}

Bij veel uitgeverijen denkt de (bureau)redactie graag mee over tekstproblemen. Schroom dus niet om te overleggen wanneer je dreigt vast te lopen.

\section{Spellingchecker}

Laat ten slotte de Word-spellingchecker naar je document kijken. Die vist er de kleinigheden ('onmiddelllijk') uit waar jij of een ander overheen leest. Je bureauredacteur zal in de wolken zijn met de schone kopij en de persklaarmaker kan zich concentreren op je vertaling zonder door ruis te worden afgeleid of beïnvloed ${ }^{3}$ : je wilt niet dat je kopij de indruk wekt dat je haastig of onzorgvuldig hebt gewerkt.

\section{Een notitie over taalvarianten}

Idealiter heerst er een levendig 'taalvariantbewustzijn' onder alle partijen in het letterenvak en staan die partijen open voor een royaal gebruik van de hele Nederlandse taalschat. Veel uitgeverijen zijn echter van oudsher in en rond Amsterdam gevestigd, waardoor een uitgesproken voorkeur is ontstaan voor een randstedelijk-Hollandse variant van het Nederlands en het kan gebeuren dat datgene wat als afwijkend van de standaardtaal wordt gevoeld - ook wanneer het dat niet is - op weerstand stuit. Iedere vertaler die zich in het dagelijkse leven omringt met een andere variant (of

2 Zie 1.7.

3 Zie ook 1.2. 
dat nu Gronings of Brabants, Antwerps of Limburgs is) krijgt daarmee te maken, bijvoorbeeld in de revisievoorstellen van persklaarmaker of bureauredacteur.

Het is goed om in het achterhoofd te houden dat (literaire) uitgeverijen die verhouding tussen talige vertrouwdheid en vernieuwing zoeken die in hun ervaring het beste verkoopt, en dat dat een grijs gebied betreft dat je als taalprofessional het beste betreedt met (tact en) gedegen kennis. Om je taalvariantbewustzijn te stimuleren kun je, behalve veel Nederlands lezen en luisteren, je vertaalkeuzes toetsen door (in)formele samenwerkingen aan te gaan met collega's uit andere delen van ons taalgebied: denk aan meelezers, co-vertalers, mentoren. Daarnaast kunnen groepen op sociale media een waardevolle vraagbaak zijn.

\section{Pkm- en correctiefase}

\section{Kopij naar de uitgever}

\section{Overdracht}

Bij de uitgeverij is de bureauredacteur je aanspreekpunt. Die regelt het 'verkeer' tussen jou en de freelancers die zich over je vertaling gaan buigen, bewaakt de planning en fungeert als arbiter bij eventuele meningsverschillen.

Vaak stuurt de bureauredacteur de aangeleverde kopij nog dezelfde dag door naar een freelance persklaarmaker. Licht de redacteur bij aanlevering in over bijzonderheden die de persklaarmaker moet weten (juridische/medische termen die al gecheckt zijn of juist nog gecheckt moeten worden, een personage met een spraakgebrek, alles waarin je bent afgeweken van de huisstijl), dat voorkomt onnodige correctievoorstellen.

Informeer bij de bureauredacteur wie je vertaling persklaar maakt, zodat je eventueel overleg kunt plegen. Het komt regelmatig voor dat een bureauredacteur vraagt of je een voorkeur hebt voor een persklaarmaker, en dan is het prettig om te kunnen vragen om de persoon die eerder een fijn klankbord is gebleken.

\section{Eerste lezer}

Zoals de vertaler 'de eerste lezer' van de brontekst is, is de persklaarmaker de eerste officiële lezer van je vertaling: de eerste tekstprofessional die met kritische aandacht jouw tekst tot in de details op zich laat inwerken. Hou er rekening mee dat de persklaarmaker de brontekst alleen van kaft tot kaft meeleest als de redactie daarom vraagt. 


\section{Kopij persklaar maken}

De persklaarmaker leest dus je vertaling van $A$ tot $Z$ en brengt correctievoorstellen aan: hetzij handmatig (rode pen/potlood) op papier, hetzij digitaal (met wijzigingen bijhouden in het Word-document). Laat het de redactie weten als je een sterke voorkeur hebt voor een van beide methoden.

De persklaarmaker corrigeert fouten op het gebied van spelling, grammatica en interpunctie en doet in het algemeen voorstellen ter verbetering - een alternatieve woordkeus, een andere volgorde van de zinsdelen - van bijvoorbeeld brontaalzweem ('vroeger of later'), regiolect, registerfouten en redundantie ('terwijl hij intussen'). Daarnaast kan de bureauredactie tekstspecifieke instructies geven: extra letten op inconsequente werkwoordstijden, stroeve dialogen signaleren et cetera. Ook realia (bestaande plaats- en personennamen, merken, film- en boektitels) worden gecheckt, en ten slotte wordt de vorm van de brontekst (aantal hoofdstukken, indeling in alinea's en bijzondere tekstsoorten zoals brieven, krantenkolommen en sms'jes) gecontroleerd en gemarkeerd op de kopij. Als de persklaarmaker voorstellen wil toelichten gebeurt dat idealiter in een afzonderlijke notitie, zodat de kopij zo schoon mogelijk blijft.

Een goede persklaarmaker gaat niet op de stoel van de vertaler zitten: persoonlijke voorkeuren horen niet mee te wegen. Structurele wijzigingen die diep ingrijpen in de tekst worden alleen doorgevoerd na overleg met de bureauredactie.

\section{Kopij terug naar de vertaler}

\section{Fiattering voorstellen persklaarmaker}

De nagekeken kopij komt via de bureauredacteur terug bij jou. Je bekijkt de aangedragen verbeteringen en voorstellen, controleert en fiatteert of weigert ze, en zorgt voor een correcte invoer van de gewenste wijzigingen in het Word-document.

In de op papier persklaar gemaakte kopij staan correctietekens in de tekst en de bijbehorende verbeteringen in de kantlijn. Een veelgebruikt onderscheid is dat tussen 'rode' en 'zwarte' voorstellen. Rood is voor pertinente fouten (spelling, huisstijl, interpunctie; woord vergeten, woord te veel; tikfout, vertaalfout), en zwart signaleert: dit zou anders mogen. Vaak zijn de zwarte voorstellen suggesties ter versoepeling van iets wat strikt genomen niet fout is maar toch gebaat is bij wijziging.

Het kleuronderscheid geeft houvast bij het beoordelen van de pkm-voorstellen. Het staat je vrij om af te wijken van suggesties die de persklaarmaker doet, of om 
voorstellen te weigeren. Hou daar in de kopij wel aantekening van bij, zodat de bureauredacteur zicht houdt op je beslissingen.

\section{Eigen wijzigingen}

In deze fase kun je nog wijzigingen uit eigen koker aanbrengen. Er zijn een paar weken verstreken sinds je de kopij naar de uitgeverij opstuurde, en in die tijd heeft je vertaling kunnen bezinken. Die rijping kun je benutten door je vertaling nogmaals helemaal door te werken. Geef wijzigingen met een eigen kleur pen aan in de papieren kopij of voorzie een gewijzigde passage van een digitale opmerking in het Word-document, zodat de bureauredacteur in een oogopslag kan zien wat er in deze fase in de kopij is gebeurd.

\section{Omgaan met kritiek}

Kritiek komt - open deur - in soorten en maten. Omgaan met kritiek is allereerst een kwestie van ervoor openstaan: het hoofd koel houden, zaken (opnieuw) controleren en keuzes (opnieuw) afwegen. Neem de tijd om de voorstellen van de persklaarmaker te bekijken. Elke externe markering of suggestie is immers een signaal dat er iets aan je tekst schort - al is misschien niet direct duidelijk wát. Het loont de moeite om een lijstje bij te houden van terugkerende kritische noten en om navraag te doen bij onduidelijkheden. Mocht kritiek in de pkm-fase een 'hard' geschilpunt vormen, overleg dan met je bureauredacteur. Bij een serieus verschil van mening kun je de kwestie voorleggen aan de uitgever met een verzoek om arbitrage.

\section{Revisie in de correctiefase}

\section{Opmaak en correctie eerste proef}

De gereviseerde kopij wordt door de dtp'er opgemaakt in een eerste proef: vanaf nu ziet je kopij eruit als de pagina's van een boek.

Er gaat een kopie van de proef naar een freelance corrector, die de tekst nog eens helemaal doorleest en fouten corrigeert. De corrector controleert ook de paginaopmaak, voor- en nawerk (inhoudsopgave, bibliografie, noten; illustraties en bijschriften) en de woordafbrekingen.

Tegelijkertijd gaat er een (digitale) kopie van de eerste proef naar jou. Het verschil met de revisieronde na het persklaar maken is groot. Vanwege (kostbaar) tekstverloop zijn in de proeffase alleen nog revisies toegestaan ter verbetering van echte fouten. 
'Cosmetische' revisie of bijschaven van een formulering die op zich niet fout is, is in het algemeen niet meer mogelijk.

Toch is het nuttig om als vertaler in deze ronde nog eens aandachtig naar de tekst te kijken: het nieuwe uiterlijk van de tekst zorgt als vanzelf voor een frisse blik. Mocht er toch nog iets over het hoofd gezien zijn, door jou of door de persklaarmaker, dan is dit het moment om het te signaleren.

\section{Revisie door de bureauredacteur}

De voorstellen van de corrector en de vertaler worden door de bureauredacteur beoordeeld en ingewerkt. Soms is er in dit stadium nog kort overleg tussen bureauredacteur en vertaler. Met de definitieve proef beginnen de voorbereidingen voor het drukken.

\section{Tijdsduur}

Doorgaans neemt de revisiecyclus van boekvertalingen twee maanden in beslag, waarvan de persklaarmaker tussen de twee en drie weken en de corrector een dag of tien gebruikt. De vertaler krijgt voor beide revisierondes gewoonlijk ongeveer een week.

\section{Aanbevolen literatuur}

Aalbrecht, Heidi, en Pyter Wagenaar. Handboek voor de redacteur. Amsterdam: Boom, 2015.

Debrabandere, Peter. "Verschillen tussen het Nederlandse en het Belgische Nederlands." Lezing Lessius Hogeschool Antwerpen, Dept. Vertaler-Tolk. 2005. Online geraadpleegd 7 januari 2019 via https://itidn.files.wordpress.com/2010/o7/lezing-antwerpen-lessius-12-06-2005.pdf.

Gerritsen, Marinel. "Vlaanderen en Nederland: waarom twee culturen en wat zijn de gevolgen in Vlaams-Nederlandse interacties?” In Neerlandia/Nederlands van nu, 2014 nr. 2.

Hendrickx, Ruud. Stijlboek VRT. Utrecht: Van Dale Lexicografie, 2003.

Mossop, Brian. Revising and Editing for Translators. Manchester: St. Jerome, 2001.

Renkema, Jan. Schrijfwijzer. Amsterdam: Boom, 2012.

Scocchera, Giovanna. "What Kind of Training for Literary Translation Revisers?" (2014). Online geraadpleegd 7 januari 2019 via http://www.intralinea.org/specials/article/2093.

Sijs, Nicoline van der (red.). Dialectatlas van het Nederlands. Amsterdam: Prometheus, 2011.

https://taaladvies.net/. Nederlandse Taalunie, 2000-2019. 



\title{
4.2. \\ Omgaan met promotie, prijzen en recensies
}

\author{
Janny Middelbeek-Oortgiesen
}

Een van de vragen waarmee een literair vertaler vaak worstelt, is wat hij - naast het aanleveren van een zo optimaal mogelijke vertaling - kan of zou moeten doen om bij te dragen aan de promotie van zijn vertaling en er mede voor te zorgen dat deze haar weg vindt naar een zo groot mogelijk publiek. Hieronder volgen een paar aanbevelingen die als leidraad kunnen dienen.

\section{Voorwerk}

Een actieve houding is van belang en een goed uitgangspunt kan zijn dat je ervoor zorgt dat je persoonlijk bekend bent bij de uitgeverij waarmee je samenwerkt. Als je een opdracht aanvaardt bij een voor jou nieuwe opdrachtgever, stel dan bijvoorbeeld voor om even langs te komen voor een kort kennismakingsgesprek met de redacteur en/of uitgever. Houd het luchtig en zeg dat het je fijn lijkt om het gezicht te zien bij de naam achter de mails en/of telefoongesprekken.

Hiermee maak je jezelf nadrukkelijk tot gesprekspartner. Zie de vertaling als jullie gezamenlijke project, waarbij jij kennis over het boek in huis hebt die de opdrachtgever (nog) niet heeft en waarvan deze profijt kan hebben.

Voordat het zover is dat een uitgever een beslissing neemt over het al of niet aankopen van de vertaalrechten van een boek, kun je als vertaler echter ook al een stap zetten door het aanleveren van (vertaalde) quotes uit recensies uit het brontaalland of uit andere landen waar het boek mogelijk al verschenen is. 
Als er subsidiemogelijkheden in het brontaalland bestaan, bijvoorbeeld een vertaal- en/of productiesubsidie of een bijdrage in de kosten bij auteursbezoek ${ }^{1}$, is het zinvol de uitgever daarop te wijzen. Zeker bij de meer 'exotische' talen zijn uitgevers lang niet altijd op de hoogte van alle mogelijkheden, terwijl dit wel een belangrijk punt kan zijn voor de uiteindelijke beslissing om de rechten van een boek aan te kopen. Verdiep je als vertaler daarom in de organisaties die in jouw brontaalland/ brontaallanden in dit verband van belang zijn.

Wanneer je op eigen initiatief of op verzoek een leesrapport schrijft, is het slim dit zodanig te doen dat delen ervan bruikbaar zijn voor de achterflap van het boek, voor promotiemateriaal en voor de aankondiging op de website van de uitgeverij. Het is niet nodig dat je je uitsluitend in superlatieven uitdrukt, wel dat je zo helder mogelijk verwoordt waar het bij het boek in kwestie om gaat.

Je kunt ook aanbieden de tekst van de achterflap en de aankondiging op de website te lezen voordat deze openbaar worden gemaakt om te voorkomen dat er feitelijke onjuistheden in komen te staan of dat er misschien te veel van de clou van het verhaal wordt weggegeven. Zelf heb ik zo eens kunnen voorkomen dat op de achterflap van een thriller al vermeld stond wie de moordenaar was ...

Zie dit als behorend bij je professionaliteit en wees niet bang om bemoeizuchtig over te komen. Alles hangt af van de toon waarop je je voorstellen doet, en als er iets is wat een vertaler kan, is het wel de juiste toon aanslaan.

\section{Nazorg}

Wanneer je vertaling verschijnt, kun je gevraagd en ongevraagd meedenken met de uitgeverij over de toezending van recensie-exemplaren aan specifieke personen of doelgroepen. Als je de smaak kent van bepaalde critici of culturele influencers, kun je voorstellen aan diegene een exemplaar toe te sturen.

Probeer ook te letten op 'haakjes' in de actualiteit, waarbij in de promotie van de vertaling aangeknoopt kan worden. Toen ik verhalende non-fictie vertaalde van een auteur die leed aan dwangneuroses en het syndroom van Gilles de la Tourette, deed ik de uitgever de suggestie aan de hand deze schrijver bij zijn bezoek aan Nederland te laten interviewen door een hoogleraar die op dat moment in het nieuws was

$1 \quad$ Zie ook hoofdstuk 1.1. 
vanwege zijn onderzoek naar dwangneuroses. Op die manier lukte het om extra publiciteit te genereren.

Ook bij dit alles geldt weer: zie je zelf nadrukkelijk als gesprekspartner van je opdrachtgever en besef dat je allebei graag wilt dat de vertaling het publiek bereikt.

Bekijk ook of je op sociale media actief wilt zijn voor de promotie van je werk. Als je daarvoor kiest, kies dan bewust welk medium of welke media bij jou passen en welke strategie je hierbij inzet. Rond de verschijning van je vertaling kun je zelf inhoud genereren, door te vermelden dat het boek is verschenen, er foto's van te plaatsen, iets over de inhoud te vertellen, eruit te citeren enzovoort. Je kunt er ook voor kiezen door middel van zoekfuncties bij te houden welke recensies en lezersreacties er verschijnen en hierop de aandacht te vestigen. Een combinatie van beide is natuurlijk ook mogelijk. Houd in elk geval voor ogen dat je het visitekaartje van je werk wilt zijn en denk goed na over de aanpak die het best bij jou en bij het werk past.

Wanneer je vertaling goed wordt ontvangen kan het gebeuren dat gevraagd wordt of je ergens een lezing wilt komen geven of aan een interview wilt meewerken ter ondersteuning van de promotie van het bewuste boek. Je medewerking zal een positief effect hebben op je relatie met de uitgever. Ook wanneer je een prijs krijgt, kun je voor lezingen en interviews worden gevraagd.

Veel vertalers vinden dat in eerste instantie 'eng' en denken dat dit niets voor hen is of dat ze het niet kunnen. Toen mijn vertaling van Marianne Fredrikssons roman Anna, Hanna en Johanna een bestseller werd en ik verzoeken begon te krijgen om aan optredens met de auteur mee te werken of zelf lezingen te verzorgen, wist ik aanvankelijk ook niet goed wat ik kon verwachten. Maar al snel bleek dat de lezers/ toehoorders welwillend waren omdat ze oprecht belangstelling hadden voor mijn werk en dat van de auteur. Ook ontdekte ik dat als je praat over een terrein dat je beter beheerst dan de toehoorders, je daar gemakkelijker over spreekt dan je op voorhand misschien denkt.

Bovendien: presenteren kun je leren. Om te 'oefenen' zou je klein kunnen beginnen en bijvoorbeeld vragen of je in een plaatselijke boekhandel naar aanleiding van de verschijning van een vertaling van jouw hand daar eens over mag komen vertellen.

In Vlaanderen wordt door het Vlaams Fonds voor de Letteren subsidie verstrekt voor lezingen ${ }^{2}$ en kan de vertaler zichzelf en zijn voorkeursonderwerpen presenteren

2 Zie 1.1. 
op de lijst met Auteurslezingen ${ }^{3}$. Dit is een extra stimulans voor vertaler én organisator. In Nederland initieert het Letterenfonds publieksactiviteiten rondom literaire vertalingen en literair vertalers, onder meer via $\mathrm{Schwob}^{4}$ en de jaarlijkse Vertalersgeluktournee.

Vergeet overigens niet in gevallen waarin een vergoeding logisch is, daarnaar te informeren of zelf je tarief te noemen. Gratis werken is geen teken van professionaliteit.

\section{Bibliografie}

Fredriksson, Marianne. Anna, Hanna en Johanna. Vertaling door Janny Middelbeek-Oortgiesen. Breda: De Geus, 1997.

3 https://www.auteurslezingen.be/auteurslezingen-literaire-vertalers. Geraadpleegd op 15 maart 2019.

4 http://www.schwob.nl/. Geraadpleegd op 15 maart 2019. 


\section{3. \\ De beoordeling van de vertaling}

Fedde van Santen

In het eerste hoofdstuk van dit boek is al ter sprake gekomen dat Nederland en Vlaanderen beschikken over een, vanuit buitenlands perspectief gezien, jaloersmakende vertaalinfrastructuur. ${ }^{1}$ Er wordt veel vertaalde literatuur uitgebracht en uitgevers betalen in vergelijking met andere landen redelijke honoraria. Uniek is dat de vertaler ook nog eens subsidies kan aanvragen, als de literaire kwaliteit van de brontekst en de kwaliteit van de vertaler daartoe aanleiding geven. De subsidieregelingen worden uitgevoerd door de letterenfondsen, het Nederlands Letterenfonds en het Vlaams Fonds voor de Letteren. Op de websites van de beide fondsen is de toepasselijke regeling te vinden. De subsidies zijn werkbeurzen en moeten dus vooraf worden aangevraagd.

Zoals gezegd is de toekenning van subsidie afhankelijk van de kwaliteit van brontekst en vertaler. Dat roept onmiddellijk vragen op. Wie beoordeelt die kwaliteit, op welke manier en met welke maatstaven? En als diegene niet dezelfde literaire smaak of vertaalopvatting heeft, is het oordeel dan automatisch negatief? Auteurs en vertalers die voor het eerst aanvragen hebben vaak het gevoel dat ze hun geesteskind, waaraan ze maandenlang zo hard hebben gewerkt en waarover ze als geen ander hebben nagedacht, onderwerpen aan een snel en subjectief, en om die reden waarschijnlijk niet billijk oordeel. In dit hoofdstuk wordt beschreven hoe aanvragen worden behandeld en vooral hoe de vertaalkwaliteit wordt beoordeeld. De beoordeling van literaire kwaliteit komt zijdelings ter sprake.

Om te beginnen een advies: lees de regelingen goed door. Wat wordt met de regeling beoogd, hoe wordt ze uitgevoerd, op welke manier moeten de letterenfondsen verantwoording afleggen over de uitvoering? Het is belangrijk te bedenken dat beide fondsen bij wet verplicht zijn hun taak ten opzichte van jou, de aanvrager, integer

$1 \quad$ Zie hoofdstuk 1.1. 
en onpartijdig uit te voeren, maar dat ze er tegelijkertijd voor moeten zorgen dat de subsidies rechtmatig worden verstrekt. De fondsen moeten kunnen verantwoorden, naar de vertaler en naar de overheid, waarom de ene aanvraag wordt afgewezen en de andere toegekend, waarom de ene vertaler een hoger bedrag krijgt dan de andere. Daarom is transparantie voor de fondsen bijzonder belangrijk. Zowel aan een expert als aan een leek moet duidelijk te maken zijn om welke redenen een subsidie wel of niet wordt toegekend.

Vertaalkwaliteit beoordelen is vanouds een heet hangijzer. Beoordelen is (nog steeds) mensenwerk en het is maar de vraag of een beoordelaar zijn eigen smaak, voorkeuren en vooroordelen kan uitschakelen om tot een voldoende objectief oordeel te komen. Een beoordeling door één persoon kan alleen dan betrouwbaar (objectief en reproduceerbaar) zijn, als er een uitgebreide beschrijving is van de te hanteren criteria. Die breed gedragen beschrijving, een beschrijving waarover alle literair vertalers en andere experts het eens zijn, bestaat niet.

De oplossing die de fondsen hebben gevonden om de beoordeling van vertalingen voldoende transparant te laten zijn, rust op drie pijlers. Om te beginnen zijn er twee principes: collegiale toetsing en intersubjectiviteit.

Met collegiale toetsing wordt bedoeld dat bij de beoordeling experts uit het werkveld worden ingeschakeld, dat wil zeggen, vertalers en andere literatoren. De te beoordelen vertaling wordt niet 'gescoord' door een ambtenaar die met hetzelfde gemak vertaalsubsidies als melkquota vaststelt, maar wordt gelezen en beoordeeld door een collega, door iemand die dezelfde waarde als jij hecht aan de kwaliteit van de vertaling. Een collega die weet hoe een vertaling tot stand komt, die bloed, zweet en tranen kan herkennen en die uit ervaring weet waar vertaalproblemen in schuilen.

Het tweede principe, intersubjectiviteit, houdt in dat een vertaling nooit door slechts één persoon wordt beoordeeld. Er zijn altijd meerdere collega’s bij betrokken en hun meningen worden door een adviescommissie met elkaar vergeleken. Door met meerdere beoordelaars te werken, worden vooroordelen en afwijkende meningen geneutraliseerd.

De derde en misschien belangrijkste pijler onder de beoordelingsprocedure is dat de ingeschakelde collega's en experts moeten verantwoorden welke criteria ze hebben gehanteerd. Bij ontstentenis van een algemeen geldende beschrijving wordt de beoordelaar aan de hand van een formulier gevraagd een oordeel te geven over verschillende aspecten van de vertaling. De beoordelaar moet met voorbeelden uit brontekst en vertaling beargumenteren waarom het oordeel over een bepaald aspect positief of negatief is. Zo kan de beoordelaar niet zonder meer stellen dat de 
vertaler 'onhandig met realia is omgegaan'. Een dergelijke vaststelling moet worden toegelicht en beargumenteerd, waarbij de beoordelaar moet aangeven wat wel 'handig' zou zijn geweest. Op dezelfde manier komt de beoordelaar er niet mee weg te schrijven dat 'de stijl van de brontekst geweld is aangedaan in de vertaling'. In dat geval moet worden omschreven wat volgens de beoordelaar kenmerkend is voor de stijl en moeten voorbeelden worden gegeven die aantonen dat die kenmerken in de vertaling niet terugkomen. De adviescommissie kan, door de beoordelaars te vragen hun oordeel uitgebreid te beargumenteren, bepalen of er billijk is geoordeeld en later kan het fonds afdoende verantwoorden of de toekenning of afwijzing rechtmatig is geweest.

Er zijn nog twee elementen van de beoordeling onbesproken gebleven, maar voordat die aan de orde kunnen komen, moet eerst de aanvraagprocedure worden behandeld.

Voor de vertaler begint het allemaal nadat de eerste (Nederland) of de tweede (Vlaanderen) literaire vertaling in boekvorm is gepubliceerd bij een reguliere uitgever. Vanaf dat moment kan voor een volgende vertaling een projectsubsidie of, zoals het in Vlaanderen heet, een projectbeurs worden aangevraagd. Er is nog een vereiste, namelijk dat de genoemde vertalingen tot stand zijn gekomen met een zogenaamd modelcontract. Dat contract is een afspraak tussen de uitgevers en de belangenorganisaties van vertalers en voorziet, onder meer, in een minimumhonorering voor de vertaler en in royalty's bij een bepaald aantal verkochte exemplaren. Bij de aanvraag kan in eerste instantie worden volstaan met een intentieverklaring, maar later moet het contract worden ingezonden.

$\mathrm{Om}$ aan te vragen kan de vertaler het aanvraagformulier van de site van het Nederlands Letterenfonds of het Vlaams Fonds voor de Letteren downloaden. Het formulier omvat vragen over de aanvrager, zoals hoeveel en welke vertalingen van zijn hand zijn gepubliceerd, over eventueel eerder verstrekte subsidies (stimuleringsbeurzen en dergelijke) en vooral over het vertaalproject. Zo moet de vertaler een motivering van de aanvraag schrijven, waarin het werk wordt belicht. De vertaler moet duidelijk maken waarom vertaling van dit werk belangrijk is voor Nederlandstalige lezers, voor het literaire landschap in Nederland en/of Vlaanderen.

De motivering moet inzicht geven in de literaire kwaliteit van het werk en in de moeilijkheidsgraad van de vertaling. Als de vertaling moeilijker dan gemiddeld is, kan de vertaler een hogere subsidie worden toegekend. Wanneer is een vertaling moeilijk? Ook hier geldt dat moet worden beargumenteerd waarin de specifieke moeilijkheden schuilen. 
In Nederland kan in sommige gevallen het subsidiebedrag nog verder worden verhoogd, bijvoorbeeld als de vertaler een voor- of nawoord schrijft, of als de vertaler extra werk heeft aan de selectie of editie van de tekst.

Het is aan te raden ruim de tijd te nemen om het aanvraagformulier in te vullen. Er hangt voor de vertaler veel vanaf en een goedverzorgde aanvraag, die van alle informatie en bijlagen is voorzien, wordt sneller afgehandeld dan eentje die is afgeraffeld.

Wanneer de aanvraag bij het fonds (bij een van de fondsen) binnenkomt, wordt eerst naar de ontvankelijkheid gekeken. Is de aanvraag compleet, kloppen de gegevens, is er een modelcontract, zijn de gevraagde exemplaren van de brontekst meegestuurd en is de aanvrager bekend? In Vlaanderen moet bovendien een fragmentvertaling, voorzien van een toelichting, worden aangeleverd. Als alles klopt, wordt de beoordeling in gang gezet.

$\mathrm{Nu}$ komen de literaire kwaliteit en de moeilijkheidsgraad aan de beurt. De fondsmedewerkers sturen exemplaren van de brontekst aan externe beoordelaars, met de vraag het werk kort te beschrijven, te plaatsen in de literaire of culturele traditie van de broncultuur en weer te geven hoe het werk daar is ontvangen. Voor de literaire kwaliteit kunnen de beoordelaars kijken naar vormaspecten en inhoudsaspecten, zoals vertelperspectief, plot, stijl, taalgebruik, klank of zeggingskracht. $\mathrm{Al}$ deze elementen leiden tot een waardering, een typering van het literaire werk op een schaal van zeer goed tot slecht.

Voor het bepalen van de moeilijkheidsgraad kunnen de beoordelaars gebruikmaken van een groot aantal aspecten, die niet alleen met de brontekst te maken hebben, maar uiteraard ook met culturele, taalkundige en literaire verschillen tussen bron- en doeltaal. Het Nederlandse formulier geeft als geheugensteuntje een korte checklist, met steekwoorden als inventiviteit, kernbegrippen, registerverschillen, klankeffecten en realia.

De vertaalvaardigheid van iemand die voor het eerst aanvraagt wordt altijd beoordeeld, ook weer anoniem en door externe experts, zoals gezegd meestal collega-vertalers. Daarvoor kijkt de beoordelaar naar een twintigtal bladzijden uit de vorige vertaling van de aanvrager, vergelijkt de vertaling met het origineel en geeft met het eerder beschreven formulier een oordeel: goed, voldoende, onvoldoende, slecht.

Voor de beoordelaars is het goed te weten dat hun oordeel slechts een onderdeel is van de totale weging. Het is niet zo dat de beoordelaar direct beslist over het toekennen of afwijzen van de aanvraag. Die verantwoordelijkheid ligt bij de fondsen.

Er is nog een laatste element dat in aanmerking wordt genomen, namelijk het track record van de aanvrager. Daarmee wordt alles bedoeld wat bij het fonds bekend 
is van de aanvrager: aantallen vertalingen, taalcombinaties, eerdere beoordelingen, eerdere toekenningen en andere gegevens.

Op een gegeven moment worden alle beoordelingen en andere stukken bij het fonds bij elkaar gevoegd en gaat het hele, inmiddels zeer forse dossier naar de adviescommissie. De commissie gaat na of de beoordelingen met elkaar stroken, of de beoordelingen billijk zijn en of er met de voorliggende informatie een beslissing kan worden genomen over de aanvraag. Als alles compleet en duidelijk is, geeft de commissie een advies aan het desbetreffende fonds, om wel of niet toe te kennen en of er reden is het standaardbedrag te verhogen. Het fonds neemt dit advies vrijwel altijd over.

De behandeling van een subsidieaanvraag is een complex en tijdrovend proces, waarbij veel mensen betrokken zijn. Alle betrokkenen, fondsmedewerkers en externe deskundigen, zijn zich terdege bewust van, en hebben vaak persoonlijke ervaring met de grote rol die subsidiëring speelt in de financiële huishouding van vertalers.

Het moge duidelijk zijn dat de fondsen een lastige taak hebben: enerzijds moeten ze overheidsgelden rechtmatig besteden en daarover gepast verantwoording afleggen, en anderzijds moeten ze billijk, redelijk en met kennis van zaken oordelen over het werk van vertalers. Het zijn geen kille uitkeringsinstanties; de medewerkers hebben werkelijk hart voor de literatuur en stellen alles in het werk om vertalers bij te staan.

Aarzel vooral niet het Nederlands Letterenfonds of het Vlaams Fonds voor de Letteren te benaderen met vragen. In dit hoofdstuk gaat het over de beoordeling, maar er zijn nog andere factoren die van invloed zijn op een aanvraag. Zo is er een inkomensgrens, kan er slechts voor een beperkt aantal vertalingen per jaar worden aangevraagd, worden meermansvertalingen (teamvertalingen) van drie of meer vertalers niet ondersteund, is er een grens aan het aantal jaren dat een onuitgegeven vertaling in beschouwing wordt genomen en zo zijn er meer beperkingen en nadere regels. En er zijn voor beginnende vertalers nog andere subsidiemogelijkheden.

Het fonds en de vertaler zijn partners die hetzelfde doel nastreven, namelijk verrijking van het literaire aanbod met kwalitatief hoogstaande vertalingen. De relatie tussen fonds en vertaler hoort een samenwerking te zijn. Juist daarom laten ervaren vertalers zich graag inschakelen als externe beoordelaar. Het is immers voor iedereen beter als het de beroepsgroep zelf is die bepaalt wat de standaard is. Via lidmaatschap van adviescommissies en ad-hocoptredens als extern adviseur, hebben vertalers invloed op de subsidiëring. Ook dit maakt onze vertaalinfrastructuur uniek in de wereld. 



\section{Bijlage I \\ Lijst van geciteerde vertalingen}

Baars, Joost. Binnenplaats. Amsterdam: Van Oorschot, 2017.

Baldwin, James. Niet door water maar door vuur. Vertaald door Harm Damsma. Amsterdam: De Geus, 2018 .

Baudelaire, Charles. Selected Poems. Translated by Joanna Richardson. Harmondsworth: Penguin, 1975. Benjamin, Walter. “De opgave van de vertaler". Vertaald door Henri Bloemen. In Naaijkens, Ton,

Cees Koster, Henri Bloemen en Caroline Meijer (red.), 2004/1923, p. 65-73.

Bindervoet, Erik en Robbert-Jan Henkes. Help! The Beatles in het Nederlands. Amsterdam: Nijgh \& Van Ditmar, 2003.

Blas de Roblès, Jean-Marie. Middernachtsberg. Vertaald door Karina van Santen en Martine Vosmaer. Amsterdam: Ailantus, 2011.

Borges, Jorge Luis. Alle gedichten. Vertaald (met verantwoording) door Maarten Steenmeijer en Barber van de Pol. Amsterdam: De Bezige Bij, 2015.

Botton, Alain de. Religie voor atheïsten. Een heidense gebruikersgids. Vertaald door Jelle Noorman. Amsterdam: Atlas, 2011.

Buwalda, Peter. Bonita Avenue. Vertaald door Arlette Ounanian. Arles: Actes Sud, 2013.

Celan, Paul, Poems of Paul Celan: A Bilingual German/English Edition. Revised edition, translated by Michael Hamburger. London: Anvil Press, 2002.

Cervantes Saavedra, Miguel de. Don Quichot. Vertaald (met verantwoording) door Barber van de Pol. Amsterdam: Athenaeum Polak \& Van Gennep, 1997.

Cervantes Saavedra, Miguel de. De geestrijke ridder Don Quichot van de Mancha. Vertaald door Johan Willem Frederik Werumeus Buning en Cornelis Frans Adolf van Dam. Amsterdam: Querido, 1941-1943.

Cervantes Saavedra, Miguel de. Leben und Thaten des scharfsinnigen Edlen Don Quixote von la Mancha. Übersetzt von Ludwig Tieck. Berlin: Johann Friedrich Unger, 1799-1801.

Claus, Hugo. L'étonnement. Vertaald door Maddy Buysse. Paris: Stock, 1976.

Claus, Hugo. Die Verwunderung. Übersetzt von Udo Birckholz. München: Limes Verlag, 1979.

Claus, Hugo. Le chagrin des Belges, traduit du néerlandais par Alain van Crugten. Paris: Julliard, 1985. Claus, Hugo. Wonder. Translated by Michael Henry Heim. New York: Archipelago Books, 2009.

Cognetti, Paolo. De acht bergen. Vertaald door Yond Boeke en Patty Krone. Amsterdam: De Bezige Bij, 2017.

Collins, Suzanne. Spotgaai (De hongerspelen 3). Vertaald door Maria Postema. Amsterdam: Van Goor, 2010.

Collins, Suzanne. Flammender Zorn (Die Tribute von Panem 3). Übersetzt von Sylke Hachmeister \& Peter Klöss. Hamburg: Friedrich Oetinger, 2011.

Collins, Suzanne. L'ocell de la revolta (Els jocs de la fam 3). Traduit per Armand Carabén. Barcelona: Grup 62, 2013. 
Collins, Suzanne. Il canto della rivolta (Hunger Games 3). Tradotto da Simona Brogli. Milano: Mondadori, 2012.

Collins, Suzanne. La révolte (Hunger Games 3). Traduit par Guillaume Fournier. Paris: Pocket Jeunesse, 2012.

Collins, Suzanne. Sinsajo (Los juegos del hambre 3). Traducido por Pilar Ramírez Tello. Barcelona: RBA Libros, 2011.

Cortázar, Julio \& Carol Dunlop. De autonauten van de kosmosnelweg: of een tijdloze reis Parij-Marseille. Vertaald door Barber van de Pol. Amsterdam: Meulenhoff, 1986.

Cowper, William, The Iliad of Homer, Translated into Blank Verse, 1791. https://www.gutenberg.org/ files/16452/16452-h/16452-h.htm. Geraadpleegd 3 september 2018.

Dahl, Roald. Matilda. Vertaald door Huberte Vriesendorp. Utrecht: De Fontein, 1998.

Dahl, Roald. Matilda. Traduit par Henri Robillot. Paris: Gallimard Jeunesse, 1997.

Dahl, Roald. Matilda. Traducido por Pedro Barbadillo. Barcelona: Alfaguara, 2005.

Descartes, René. Bibliotheek Descartes, Band 3. Vertaald door Jeanne Holierhoek. Amsterdam: Boom, 2011.

Diesthemius, Petrus. Den spyeghel der saligheyt van Elckerlijc / De spiegel van de verlichting van de Iedereen. Vertaald en bewerkt door Erik Bindervoet. Amsterdam: De Harmonie, 2016.

Dylan, Bob. Liedteksten 1962-1973 en Liedteksten 1974-2001. Vertaald door Bindervoet en Henkes. Amsterdam: Nijgh \& Van Ditmar, 2016.

Dylan, Bob. Liedteksten 2002-2012. Vertaald door Bindervoet en Henkes. Amsterdam: Nijgh \& Van Ditmar, 2017.

Dylan, Bob. Tarantula. Vertaald door Bindervoet en Henkes. Amsterdam: Nijgh \& Van Ditmar, 2017. Edogawa, Ranpo. “Gifkruid”. Vertaald door Luk Van Haute in Liefdesdood in Kamara (2014), p. 114-118. Edogawa, Ranpo. "Poison Weeds". Vertaald door Seth Jacobowitz in The Edogawa Rampo Reader. Kurodahan Press, 2008, p. 35-41.

Eeden, Frederik van. Johannes Viator. Il libro dell'amore. Vertaald door Franco Paris. Roma: Tilopa, 1996. Fanon, Frantz. Zwarte huid, witte maskers. Vertaald door Jeanne Holierhoek. Amsterdam: Octavo, 2018. Foucault, Michel. De geboorte van de biopolitiek. Vertaald door Jeanne Holierhoek. Amsterdam: Boom, 2013 .

Foucault, Michel. Geschiedenis van de seksualiteit. Vertaald door Jeanne Holierhoek. Amsterdam: Boom, 2018.

Fredriksson, Marianne. Anna, Hanna en Johanna. Vertaald door Janny Middelbeek-Oortgiesen. Breda: De Geus, 1997.

French, Albert. Holly. Vertaald door Rien Verhoef. Amsterdam: Balans, 1996.

Gilliams, Maurice. Elias ou le combat contre les rossignols suivi de Monsieur Albéric. Traduit par Saint-Rémy. Antwerpen: Librairie des Arts, 1968.

Gilliams, Maurice. Elias, or The struggle with the nightingales. Translated by André Lefevere. Los Angeles: Sun \& Moon Press, 1995.

Ginzburg, Natalia. Familielexicon. Vertaald door J.H. Klinkert-Pötters Vos. Amsterdam: Meulenhoff. $1991 / 1988$.

Guène, Faïza. Morgen kifkif. Vertaald door Frans van Woerden. Amsterdam: Luitingh-Sijthoff, 2005. 
Guène, Faïza. Kiffe Kiffe Tomorrow. Translated by Sarah Adams. Boston: Houghton Mifflin Harcourt, 2006.

Guène, Faïza. Mañana será otro día. Traducido por Jordi Martín Lloret. Barcelona: Salamandra, 2006.

Hadewijch, Liefdesliederen. Vertaald door Jan Kuijper. Amsterdam: Athenaeum-Polak \& Van Gennep, 2010.

Harstad, Johan. Max, Mischa en het Tet-offensief. Vertaald door Edith Koenders en Paula Stevens. Amsterdam: Podium, 2017.

Hayashi, Fumiko. “Downtown”. Vertaald door Luk Van Haute in Liefdesdood in Kamara (2014), p. 170-184.

Hayashi, Fumiko. “Downtown”. Translated by Ivan Morris in Modern Japanese Stories. Charles E. Tuttle, 1962, p. 349-364.

Hiraide, Takashi. De kat. Vertaald door Luk Van Haute. Amsterdam: Meulenhoff, 2015.

Hiraide, Takashi. The Guest Cat. Translated by Eric Selland. New York: New Directions, 2014.

Hillesum, Etty. Les écrits d'Etty Hillesum. Journaux et lettres 1941-1943, édition intégrale, traduit du néerlandais et de l'allemand par Philippe Noble avec la collaboration d'Isabelle Rosselin. Paris: Seuil. 2008 p. 25-28.

Hooft, P.C. Nederlandse historiën in het kort. Samengesteld door Martinus Nijhoff. Amsterdam/ Brussel: Elsevier, 1947

Hooft, P.C. Uit de Nederlandse Historiën van P.C. Hooft. Bijeengebracht en bewerkt door A.C. Niemeyer en F.J. Schmit. Amsterdam: Meulenhoff, 1960.

Ichikawa, Takuji. Bij jou zijn. Vertaald door Geert van Bremen. Amsterdam: Contact, 2011.

Inoue, Yasushi. "Kroniek van de overtocht naar Fudaraku”. Vertaald door Luk Van Haute in Liefdesdood in Kamara (2014), p. 205-226.

Joyce, James. Dublinezen. Vertaald door Erik Bindervoet en Robbert-Jan Henkes. Amsterdam: Athenaeum, 2016.

Kawabata, Yasunari. Schoonheid en verdriet. Vertaald door Luk Van Haute. Amsterdam: Meulenhoff, 2005 .

Kawakami, Hiromi. De tas van de leraar. Vertaald door Luk Van Haute. Amsterdam: Atlas, 2010.

Kawakami, Hiromi. Der Himmel ist blau, die Erde ist weiß. Übersetzt von Ursula Gräfe \& Kimiko Nakayama-Ziegler. München: Carl Hanser Verlag 2008.

Kawakami, Hiromi. Les années douces. Vert. Elisabeth Suetsugu. Arles: Picquier 2005.

Kawakami, Hiromi. The Briefcase. Translated by Allison Markin Powell. Berkeley, CA: Counterpoint, 2012.

Kopland, Rutger. Songer à partir. Traduit par Paul Gellings. Paris: Gallimard, 1986.

Kraus, Karl. De laatste dagen der mensheid. Vertaald door Erik Bindervoet \& Robbert-Jan Henkes. Amsterdam: De Harmonie, 2008.

Kuijer, Guus. Das Glück kommt wie ein Donnerschlag. Übersetzt von Sylke Hachmeister. Hamburg: Friedrich Oetinger, 2003.

Kuijer, Guus. Le bonheur surgit sans prévenir. Traduit par Maurice Lomré. Paris: L'école des loisirs, 2009.

Kuijer, Guus. Poleke. La felicidad llega por sorpresa. Traducido por Goedele De Sterck. México D.F.: Castillo, 2017. 
Lamb, Charles en Mary. Sprookjes en vertellingen naar Shakespeare. Vertaald door H.I. Onnes-de Groot. Amsterdam/Brussel: Agon Elsevier, 1969.

Lawrence, D.H. De gevederde slang. Vertaald door H.W.J. Schaap. Amsterdam: Uitgeverij Contact, 1969.

Lekens, Frank. Shakespeares sonnetten; interpretatie en vertaling. http://fmlekens.home.xs4all.nl/ Q1609/. Geraadpleegd 15 januari 2019.

Lenoir, Frédéric. God? Vertaald door Jelle Noorman. Utrecht: Ten Have, 2013.

Lodge, David. La vie en sourdine. Traduit par Maurice et Yvonne Couturier. Paris: France loisirs, 2009.

Marías, Javier. Een hart zo blank: roman. Vertaald door Aline Glastra van Loon. Amsterdam: Meulenhoff, 1993.

Marías, Javier. Mein Herz so weiß. Übersetzt von Elke Wehr. Stuttgart: Klett-Cotta. 1996.

Mbembe, Achille. Kritiek van de zwarte rede. Vertaald door Jeanne Holierhoek en Katrien Vandenberghe. Amsterdam: Boom, 2015 .

Melville, Herman. Moby Dick. Vertaald door Emy Giphart. Amsterdam: L.J. Veen's Uitgeversmij N.V., [1961].

Melville, Herman. Moby Dick of de walvis. Vertaald door S. Westerdijk. Utrecht en Antwerpen: Spectrum, 1979 .

Melville, Herman. Moby Dick. Vertaald door Barber van de Pol (met verantwoording). Amsterdam: Athenaeum Polak \& Van Gennep, 2008.

Mitchell, David. De niet verhoorde gebeden van Jacob de Zoet. Vertaald door Harm Damsma en Niek Miedema. Amsterdam: Ailantus, 2010.

Multatuli. Max Havelaar: of de koffieveilingen van de Nederlandse Handelmaatschappij. Hertaald en bewerkt door Gijsbert van Es. [Rotterdam]: NRC Boeken, 2010.

Murakami Haruki. Dance Dance Dance. Translated by Alfred Birnbaum. Tokyo: Kodansha International, 1994 .

Murakami Haruki. Dans dans dans. Vertaald door Luk Van Haute. Amsterdam: Atlas, 2008.

Nietzsche, Friedrich. De genealogie van de moraal: een strijdschrift. Vertaald door Thomas Graftdijk; herzien, geannoteerd en van een nawoord voorzien door Hans Driessen. Amsterdam: Arbeiderspers, 2005 .

O’Connell, Mark. De mensmachine. Vertaald door Jelle Noorman. Amsterdam: Podium, 2018.

Ovidius Naso, Publius. De kunst der vrijage: twintig eeuwen oude maar niet verouderde liefdeswenken. Bewerkt door Jan Meihuizen. Amsterdam: Strengholt, 1941.

Ovidius Naso, Publius. De minnekunst \& Remedies tegen de liefde. Vertaald door Eddy de Laet. Antwerpen: Standaard Uitgeverij, [1978].

Ovidius Naso, Publius. Lessen in liefde. Vertaald door Marietje d'Hane-Scheltema. Amsterdam: Athenaeum-Polak \& Van Gennep, 2004.

Oz, Amos. Een verhaal van liefde en duisternis. Vertaald door Hilde Pach. Amsterdam: De Bezige $\mathrm{Bij}, 2006$.

Oz, Amos. Une histoire d'amour et de ténèbres. Traduit par Sylvie Cohen. Paris: Gallimard, 2004.

Perec, Georges.'t Manco. Vertaald door Guido van der Wiel. Amsterdam: De Arbeiderspers, 2009.

Porter, Max. Verdriet is het ding met veren. Vertaald door Saskia van der Lingen. Amsterdam: Bezige $\mathrm{Bij}, 2017$. 
Proust, Marcel. Swanns kant op. Vertaald en van een nawoord voorzien door Martin de Haan en Rokus Hofstede. Amsterdam: Atheneum Polak \& Van Gennep, 2015.

Proust, Marcel. In de schaduw van meisjes in bloei. Vertaald door Philippe Noble en Désirée Schyns. Amsterdam: De Bezige Bij, 2018.

Puett, Michael, Christine Gross-Loh. De Weg - Wat Chinese filosofen ons over het goede leven leren. Vertaald door Jelle Noorman. Utrecht: Ten Have, 2016.

Queneau, Raymond \& Umberto Eco. Esercizi di stile, Turin: Einaudi, 1983.

Rostand, Edmond. Cyrano de Bergerac. Vertaald door Laurens Spoor. Amsterdam: Bert Bakker, 2003.

Rostand, Edmond. Cyrano de Bergerac. Vertaald door Erik Bindervoet. Amsterdam: De Nieuwe Toneelbibliotheek, 2018.

Rot, Jan. Rot voor u. Hellevoetsluis: Stichting Okapi / Stichting Jan Rot, 2010.

Sartre, Jean-Paul. Het zijn en het niet. Vertaald door Frans de Haan. Rotterdam: Lemniscaat, 2003.

Saunders, George. Lincoln in de bardo. Vertaald door Harm Damsma en Niek Miedema. Amsterdam: De Geus, 2017.

Schutten, Jan Paul. Der Mensch oder Das Wunder unseres Körpers und seiner Billionen Bewohner. Übersetzt von Verena Kiefer. Hildesheim: Gerstenberg, 2016.

Schutten, Jan Paul. La respuesta eres tú y tus billones de habitantes. Traducido por Goedele De Sterck. Madrid: Maeva, 2019.

Shakespeare, William. Romeo \& Julia. Vertaald door Erik Bindervoet. Amsterdam: De Nieuwe Toneelbibliotheek, 2016.

Sollie, André. Deux par deux. Traduit par Isabelle Rosselin. Paris: Sarbacane, 2005.

Sollie, André. Doble Didi. Traducido por Goedele De Sterck. México D. F.: Fondo de Cultura Económica, 2007.

Swan, Susan. Genadeloze meisjes. Vertaald door Inge de Jong. Amsterdam: Arena, 1996.

Smith, Ali. Herfst. Vertaald door Karina van Santen en Martine Vosmaer. Amsterdam: Prometheus, 2018.

Smith, Ali. Winter. Vertaald door Karina van Santen en Martine Vosmaer. Amsterdam: Prometheus, 2018.

Tawada, Yoko. De Berghollander. Samenstelling, vertaling en nawoord door Bettina Brandt en Désirée Schyns. Amsterdam: Voetnoot, 2010.

Tsjechov, Anton. Meeuw. Bewerkt door Erik Bindervoet \& Ingejan Ligthart Schenk. Amsterdam: De Nieuwe Toneelbibliotheek, 2018.

Tsjechow, Anton. De Meeuw. In: Verzamelde Werken 6. Vertaald door Charles B. Timmer. Amsterdam: Van Oorschot, 1956.

Van Haute, Luk. Liefdesdood in Kamara en andere Japanse verhalen. Amsterdam: Atlas Contact, 2014. Wallace, David Foster. De bleke koning. Vertaald door Iannis Goerlandt en Daniël Rovers. Amsterdam: Meulenhoff, 2013.

Young, Damon. Afgeleid. Vertaald door Jelle Noorman. Utrecht: Ten Have, 2014.

Zweig, Stefan. De wereld van gisteren. Vertaald door Willem van Toorn. Amsterdam: Arbeiderspers, 2016/1990. 



\section{Bijlage II \\ Bioschetsen van de auteurs}

Erik Bindervoet is geboren in 1962 . Hij vertaalde met R.J. Henkes alle werken van James Joyce, The Beatles en Bob Dylan. Hij vertaalde solo onder meer Much Ado about Nothing en Romeo \& Julia van William Shakespeare en Cyrano de Bergerac van Rostand. Hij werkt momenteel aan een dichtbundel over dromen.

Henri Bloemen (1957) is hoofddocent aan KU Leuven Campus Antwerpen. Hij doceert daar vertaalwetenschap, vertaaltheorie, literair vertalen Duits-Nederlands en juridisch vertalen. Hij doet onderzoek naar en publiceert over de theorievorming in de vertaalwetenschap, de geschiedenis van het vertaaldiscours en de didactiek van het literair vertalen. Hij is medeauteur van het PETRA-E-framework, een Europees referentiekader voor de opleiding van literair vertalers, medeoprichter en voormalig codirecteur van het Expertisecentrum Literair Vertalen.

Paul Claes (Leuven 1943) studeerde klassieke talen, Nederlands en Engels en promoveerde tot doctor in de Letteren aan de Leuvense Universiteit. Hij doceerde aan de universiteiten van Nijmegen en Leuven en aan de hogescholen van Antwerpen en Gent. Behalve wetenschapper is hij romancier, dichter, essayist en bloemlezer. Hij vertaalde uit het Grieks, Latijn, Frans, Engels en Duits auteurs als Sappho, Catullus, Nerval, Mallarmé, Rimbaud, Bataille, Joyce, Pound, Eliot, Yeats en Rilke. In 1996 kreeg hij de Martinus Nijhoff Prijs voor vertaling. Zijn studie Gouden vertaalregels. Tips voor beginnende (en andere) vertalers (Nijmegen: Vantilt) verscheen in 2018.

Harm Damsma en Niek Miedema vormen al meer dan vijfentwintig jaar een hecht vertalersduo. Samen vertaalden zij, naast klassiekers als Ivanhoe, A Clockwork Orange en Lord of the Flies en veelbelovende debuten van Reif Larsen, Ayana Mathis, Tod Wodicka en Garth Risk Hallberg, onder meer werk van Jonathan Coe, Michel Faber, Hilary Mantel, David Mitchell, Joseph O'Connor, Richard Powers, George Saunders, Adam Thorpe en Colson Whitehead. In najaar 2019 verschijnt hun vertaling van The Great Believers van Rebecca Makkai. Harm en Niek zijn als docent verbonden aan de Vertalersvakschool in Amsterdam en Antwerpen, en hebben beiden met enige 
regelmaat meegewerkt aan cursussen van de Master Literair Vertalen in Utrecht. In 2016 ontvingen zij de Vertaalprijs van het Nederlands Letterenfonds.

Goedele De Sterck (1966) is gepromoveerd in de Spaanse Taalkunde en is verbonden aan de Universiteit van Salamanca als docente en onderzoekster binnen de vakgroep Vertalen en Tolken. Ze is al bijna twintig jaar werkzaam als literair vertaalster Nederlands-Spaans en heeft een honderdtal titels op haar naam staan, met name fictie, non-fictie en kinder- en jeugdliteratuur. Ze vertaalde onder meer werken van Bart Moeyaert, Lieve Joris, Guus Kuijer, Geert Mak, Erwin Mortier, Nescio, Frederik van Eeden, Paul van Ostaijen, Frank Westerman en Tommy Wieringa. Daarnaast schrijft ze over vertalen, houdt lezingen, modereert workshops, geeft onlinecursussen en treedt op als mentor van aankomende vertalers. In 2018 is ze bekroond met de Letterenfonds Vertalersprijs. Ze is nauw betrokken bij het PeTra-E Netwerk, MediterraNed en Small is Great (CEATL).

Nicolette Hoekmeijer (1962) studeerde Engelse Taal- en Letterkunde aan de Universiteit van Amsterdam en werkt inmiddels een kleine dertig jaar als literair vertaler Engels, waarvan de eerste zeventien jaar in combinatie met ondertitelwerk. Ze vertaalt onder meer Nathan Englander, Toni Morrison, Edward St Aubyn, Maggie Nelson en, samen met Molly van Gelder, Valeria Luiselli. Daarnaast vertaalt ze journalistieke teksten voor 360 magazine en De Groene Amsterdammer. Ze is docent aan de Vertalersvakschool in Amsterdam, verzorgt vertaalateliers voor onder meer de Master Literair Vertalen en mentort zo nu en dan beginnende vertalers. Sinds 2010 organiseert ze samen met collega Andrea Kluitmann en Hanneke Marttin van het Nederlands Letterenfonds de jaarlijkse Vertalersgeluktournee.

Jeanne Holierhoek (1947) stapte in de loop van haar vertaalleven geleidelijk over van literaire naar meer filosofische teksten. Ze vertaalde bijvoorbeeld romans van Michel Tournier, Jean Giono en Marie Ndiaye, maar ook filosofische teksten en essays van Montesquieu, Descartes, Malabou, Serres, Bergson, Foucault. Daarnaast gaf ze les in vertalen, onder andere aan de Hogeschool Maastricht, aan de Universiteit van Utrecht en aan de Vertalersvakschool, had ze zitting in verschillende jury's, schreef ze artikelen over vertalen, gaf ze lezingen, workshops en fungeerde ze als mentor voor in totaal een tiental beginnende vertalers. Haar vertaaloeuvre werd bekroond met de Dr. Elly Jaffé Prijs (2007) en met de Martinus Nijhoff Prijs (2018). 
Onno Kosters is dichter en vertaler en als docent-onderzoeker verbonden aan de opleiding Engels en de masterprogramma's Vertaalwetenschap en Literature Today van de Universiteit Utrecht. Hij promoveerde in 1999 op het werk van James Joyce (Ending in Progress: Final Sections in James Joyce's Prose Fictions). In 2007 ontving hij de Filter Vertaalprijs voor zijn vertaling van Samuel Becketts roman Watt. Hij publiceerde artikelen in Filter onder meer over vertalingen van The Waste Land, Omeros en Asterix en de Britten. Poëzievertalingen van zijn hand zijn Seamus Heaney, District en Circle (2013), Adam Foulds, Het gebroken woord (2014; beide met Han van der Vegt) en het lange prozagedicht van Patti Smith, Het nieuwe Jeruzalem (2018). In 2013 was hij de winnaar van de Turing Nationale Gedichtenprijs. Zijn meest recente dichtbundels zijn Vangst (2014) en Waarvan akte (2018). Hij is sinds 2018 als wetenschappelijk medewerker verbonden aan het Expertisecentrum Literair Vertalen (ELV). www.doelverdediger.nl.

Stella Linn is sinds 1990 verbonden aan de Rijksuniversiteit Groningen, waar zij over vertaalwetenschap en literatuur doceert. Daarvoor was zij drie jaar werkzaam als vertaalster bij de Europese Unie. Zij publiceerde diverse literaire vertalingen en is coauteur van de handboeken Vertalen uit het Frans, tekst en uitleg (Coutinho 2010, in samenwerking met Arie Molendijk) en Vertalen uit het Spaans, tekst en uitleg Spaans (Coutinho 2007, met Miel Slager). Zij heeft over uiteenlopende aspecten van het vertalen gepubliceerd en verdiept zich sinds enkele jaren vanuit verschillende academische invalshoeken in het fenomeen straattaal. Zie https://www.rug.nl/ staff/s.i.linn/ en https://www.researchgate.net/profile/Stella_Linn.

Janny Middelbeek-Oortgiesen studeerde Zweedse taal- en letterkunde, Algemene Literatuurwetenschap en Kunstgeschiedenis aan de Rijksuniversiteit Groningen.

Ze vertaalt Zweedse literatuur in het Nederlands, adviseert uitgevers en is als recensent verbonden aan Swedish Book Review. Voor het Expertise Centrum Literair verzorgt ze workshops Literair Vertalen Zweeds en treedt ze als mentor op. Middelbeek-Oortgiesen vertaalt zowel fictie als non-fictie en heeft ook een aantal toneelvertalingen op haar naam staan. Van de Zweedse Academie ontving ze in 2013 de Tolkningspriset voor haar gehele oeuvre. Uit handen van het Nederlands Letterenfonds nam ze in 2018 de Letterenfonds Vertaalprijs in ontvangst. In 2019 werd Middelbeek-Oortgiesen met De Polyglotte Geliefden, haar vertaling van de roman De Polyglotta Älskarna van de Zweedse auteur Lina Wolff, genomineerd voor de Europese Literatuurprijs. 
Philippe Noble (1949) studeerde klassieke talen, Frans en Nederlands in Parijs (Sorbonne) en Amsterdam (Universiteit van Amsterdam). Hij was van 1979 t/m 1992 universitair docent Nederlandse taal en letterkunde aan de Sorbonne en trad daarna in diplomatieke dienst. Als zodanig was hij onder meer directeur van het Frans cultureel instituut in Amsterdam, cultureel attaché bij de Franse ambassade in Den Haag en later in Wenen. Noble is literair vertaler en directeur de collection van de reeks vertaalde Nederlandstalige literatuur bij uitgeverij Actes Sud. Hij vertaalde een zestigtal werken uit het Nederlands in het Frans (o.a. van Multatuli, du Perron, Etty Hillesum, Mulisch, Nooteboom, David Van Reybrouck) en maakte samen met Désirée Schyns een hervertaling van À l'ombre des jeunes filles en fleurs in het Nederlands. Voor zijn vertaalwerk ontving hij onder meer de Nijhoffprijs en de Prix des Phares du Nord.

Jelle Noorman (1964) studeerde Franse taal- en letterkunde aan de Universiteit van Amsterdam. Hij is sinds 1987 werkzaam als literair vertaler uit het Engels, Frans Spaans en Portugees. Naast romans en verhalenbundels van onder anderen Richard Powers, Nick Hornby, Julian Barnes, Émile Zola, Alexandre Jardin en Jaime Bayly heeft hij de meest uiteenlopende (cultuur)historische, filosofische en essayistische non-fictiewerken vertaald van auteurs als Alain de Botton, Saul Bellow, Mark O’Connell, Roman Krznaric, Michael Puett en Christine Gross-Loh. Verder is hij de schrijver van twee essayistische werken over Frankrijk: De haan op de mesthoop: een culturele geschiedenis van Frankrijk (2001) en Mijn Frankrijk (2004). In 2014 verscheen zijn roman Geen tijd voor Proust.

Franco Paris is werkzaam als neerlandicus en literair vertaler. Hij doceert Nederlandse Taal- en Letterkunde aan de Università L'Orientale in Napels en coördineert vertaalworkshops op verschillende Europese universiteiten. Hij vertaalt poëzie, theater, jeugdboeken, fictie en non-fictie uit het Nederlands en uit het Engels in het Italiaans. In 2004 werd hij bekroond, als eerste laureaat, met de Vertalersprijs van het Nederlands Literair Productie- en Vertalingenfonds. Hij vertaalde werken van onder meer Ruusbroec, Beatrijs van Nazareth, Bredero (de enige integrale vertaling van het Groot-Liedboeck), Huizinga, Van Schendel, Van Eeden, Gandhi, Gibran, Claus, Krabbé, Haasse, Enquist, Nooteboom, Van der Zijl, Draaisma, Grunberg, Mak, Brijs, Van Reybrouck, Fabre, Lauwers en veel Vlaamse en Nederlandse dichters. Hij publiceert over Nederlandse en Italiaanse literatuur. Sinds 2008 is hij buitenlands erelid van de Koninklijke Academie voor Nederlandse Taal en Letteren (KANTL) te Gent. 
Désirée Schyns is als hoofddocent Vertalen Frans-Nederlands en Vertaalwetenschap verbonden aan de Faculteit Letteren en Wijsbegeerte van de Universiteit Gent en redacteur van Filter. Zij publiceert over vertaling in een postkoloniale context, getuigenis in vertaling en over memory studies en translation studies. Zij is de auteur van La mémoire littéraire de la guerre d'Algérie dans la fiction algérienne francophone (2012), co-editor van "Translation in Exile" (themanummer Cadernos de tradução, 2018) en van Denken over poëzie en vertalen. De dichter Cees Nooteboom in vertaling (2018, met Philippe Noble). Zij vertaalde werk van Assia Djebar, Nancy Huston, Malika Mokeddem, Sarah Kofman, Yoko Tawada (uit het Duits met Bettina Brandt) en recent À l'ombre des jeunes filles en fleurs van Marcel Proust (met Philippe Noble).

Carlo Van Baelen was veertig jaar actief in de boekensector als boekhandelaar, uitgever, importeur, beroepsfederatie vVB. Als directeur leidde hij het Vlaams Fonds voor de Letteren van 2000 tot 2011. Auteur van diverse rapporten en studies over economische, juridische en beleidsaspecten van het Nederlandse en Vlaamse Boekenvak. Docent aan de Bibliotheekopleiding vspw Gent en gastdocent aan de Universiteit Antwerpen, de Universiteit Gent, de KU Leuven, de Vrije Universiteit Brussel, de Universiteit Hasselt, het Plantin Genootschap en de Vakopleiding Boekenbranche Nederland. Bestuurder in literaire, culturele en maatschappelijke organisaties als vaV, fOLIO, CEGO vzw, Reprobel, Auvibel, vsPW-Gent.

Laura van Campenhout (1954) studeerde summa cum laude af in de Engelse taal- en letterkunde aan de Universiteit van Amsterdam en werkte als gerechtstolk in strafzaken. Haar overstap naar het boekenvak begon met tien jaar bureauredacteurschap bij uitgeverij De Geus. Daarna is ze aan de slag gegaan als zelfstandig boekvertaler, persklaarmaker en lector. Ze vertaalt literatuur en literaire non-fictie van het Engels naar het Nederlands en redigeert vertaald en oorspronkelijk werk van anderen. Ze geeft in Nederland en Vlaanderen lezingen en workshops over persklaar maken en corrigeren. Onder de naam Gertrudsdottir schrijft ze over de kunsten op haar blog Prent van de Week.

Jeroen Vandaele is hoofddocent Spaans aan de Universiteit Gent (vakgroep Vertalen, Tolken en Communicatie). Hij doceert er onder andere Spaanstalige Letterkunde, Literaire Vertaling, en een module over stijl in vertaling. Eerder was hij hoogleraar Spaans aan de Universiteit van Oslo, waar hij onder meer colleges Vertaalwetenschap en Cognitieve Literaire Theorie verzorgde. Zijn onderzoek richt zich op de 
snijpunten van vertaling, ideologie, narratieve retoriek, cognitie en humor. Enkele representatieve publicaties zijn het tweeluik "Narrative Humor" (Poetics Today, 2010 en 2012), de monografie Estados de Gracia. Billy Wilder y la censura franquista (Brill, 2015) en "The Philosophy Is in the Telling: How Narrativity Embodies Cogitation in Javier Marías's The Infatuations" (Neophilologus, 2018). Vandaele is lid van de Adviescommissie Vertalingen in het Nederlands (Vlaams Fonds voor de Letteren).

Chris Van de Poel is werkzaam aan de KU Leuven, Faculteit Letteren, Campus Antwerpen. Zij doceert vertaling uit het Spaans in de bachelor Toegepaste Taalkunde en de Master Vertalen en is coördinator van de opleiding literair vertalen. $\mathrm{Zij}$ publiceerde literaire vertalingen uit het Frans en het Spaans en promoveerde op zeventiende-eeuwse Nederlandse vertalingen van Spaanse satirische teksten. $\mathrm{Zij}$ is sinds 2015 wetenschappelijk medewerker bij het Expertisecentrum Literair Vertalen (ELV).

Barber van de Pol is schrijfster, essayist en vertaalster. $\mathrm{Zij}$ studeerde in Amsterdam, gaf vertaalcollege in Groningen, maar maakte alweer twintig jaar geleden de switch als docent naar de Schrijvers Vakschool Amsterdam. Zij vertaalde veel uit het Spaans, met Borges en Cortázar als Latijnsamerikaanse favorieten en Cervantes (Don Quichot) en Quevedo als de Spaanse. Met Maarten Steenmeijer samen vertaalt en bloemleest zij Spaanstalige dichters; met hem vertaalde zij ook La Regenta, de negentiende-eeuwse klassieker van Clarín. Los van het Spaanse taalgebied verscheen in 2008 haar vertolking van Melville's meesterwerk, Moby Dick, ook een grote favoriet. Als toneelvertaalster maakte ze vertalingen van onder meer Schiller (Mary Stuart), Hebbel, Kleist, Djuna Barnes. Zij schreef columns over vertalen voor Filter en De Groene en bracht haar vertaalopvattingen bijeen in de boeken Cervantes \& co, in plaats van voetnoten (2000) en Mobydickiana (2009). Ze ontving al jong de Martinus Nijhoffprijs.

Luk Van Haute (1963) studeerde Japanse literatuur aan de Universiteit van Tokio en promoveerde op het vroege werk van Nobelprijswinnaar Kenzaburo Oë. Naast Oë vertaalde hij onder meer Haruki Murakami, Soseki Natsume en Yasunari Kawabata. In 2015 ontving hij de Filter Vertaalprijs voor de door hem samengestelde bloemlezing Liefdesdood in Kamara en andere Japanse verhalen. Van Haute is ook auteur van de non-fictie boeken Japan: Schetsen uit het leven en Revival van de Japanse film, en hij schreef tal van artikelen over de Japanse cultuur en samenleving voor diverse kranten 
en tijdschriften. Hij heeft over die onderwerpen ook gedoceerd aan de Universiteiten van Leiden, Leuven en Gent.

Fedde van Santen (1959) kwam na een studie Spaanse Taal- en Letterkunde aan de Universiteit van Amsterdam min of meer bij toeval in het vertaalvak terecht. Eerst als zelfstandige, later als vertaler bij een grote Nederlandse instelling. Na 25 jaar en uitstapjes naar het toenmalige Literair Productie- en Vertalingenfonds en de Adviesraad van het Nederlands Fonds voor de Letteren leidde (weer) het toeval hem tot het vertaalonderwijs. Sinds meer dan tien jaar is hij op twee fronten actief: als lector toegepaste vertaaltheorie bij ITV Hogeschool voor Tolken en Vertalen in Utrecht en als directeur van de Vertalersvakschool, de academie voor literair vertalen in Amsterdam en Antwerpen.

Ine Willems (1971) studeerde in 1996 af in de specialisaties literatuurwetenschap en vertalen Engels aan de universiteit Utrecht en verhuisde vervolgens naar Groot-Brittannië, waar ze als inhouse-vertaler en meertalig klantencontact enige jaren voor Eurotunnel heeft gewerkt. Bij terugkomst in Nederland is ze met de Vertalerij teksten en vertalingen voor bedrijfsleven en overheid gaan verzorgen, en sinds 2003 werkt ze daarnaast als literair vertaler, met auteurs als Lawrence Hill, James Jones en Hilary Mantel in haar portfolio. Voor haar is literair vertalen een specialisatie die alle genres omvat, of ze nu commercieel zijn of tot de bellettrie behoren. In 2010 heeft ze het Literair Vertaalatelier opgericht, waarmee ze lezingen en cursussen geeft over verhaalanalyse, literair vertalen en persklaar maken \& correctie. Ze is als docent betrokken bij de Vertalersvakschool, begeleidt stages en afstudeeropdrachten literair vertalen en verzorgt gastlessen literair vertalen op middelbare scholen. 



\section{Namenregister}

Aalbrecht, Heidi 247 Abish, Walter 117, 119 ACE Traductores 236 Adams, Sarah 238, 261 Akihito (keizer) 94 Albers, Frank 101, 103 Albertus Magnus 183 Allen, Woody 145 Alvstad, Cecilia 142 Anbeek, Ton 153, 167 Antonopoulou, Eleni 138, 141 Aquino, Thomas van 183 Aristoteles 200, 206 Asscher, Maarten 182 Attwater, Juliet 172, 181 Atwoord, Margaret 49-50, 52 Austin, Liddie 52 Auteursbond 12, 236 Baardman, Gerda 63 Baars, Joost 56, 60, 259 Baelen, Carlo Van 11-18, 269 Baker, Mona 86 Bakhtin, Mikhail 121, 129 Baldwin, James 207, 209, 259 Barbadillo, Pedro 237, 260 Barthes, Roland 41 Battus (Hugo Brandt Corstius) 25, 27, 117, 119

Baudelaire, Charles 177-178, 181-182, 259

Bax, Marcel 181

Beatles, The 115, 119, 181, 259, 265

Beatrijs van Nazareth 144,268

Bee Gees, de 183

Belastingdienst 14

Bellay, Joachim du 79

Bellos, David 129, 131, 137, 141, 182

Benjamin, Walter 80, 84-85, 259

Bergh, Hans van den 138, 142

Bergson, Henri 200, 266

Berman, Antoine 80,85

Bernhardt, Sarah 43

Bernlef, J. 158, 167, 179, 181

Bernstein, Charles 182

Biesheuvel, Maarten 55-56
Bindervoet, Erik 63, 69, 114-115, 119, 181, 183-198, 259-261, 263, 265

Birckholz, Udo 160-161, 164-167, 259

Birnbaum, Alfred 95, 262

Blas de Roblès, Jean-Marie 69, 259

Bloemen, Henri 27, 73-86, 95 , 259, 265

Blok, W. 181-182

Bly, Robert 178-181

Boek.be 17

Boeke, Yond 63, 69, 259

Boland, Hans 56,60

Booth, Wayne C. 131, 133, 141

Borges, Jorge Luis 57, 60, 116, 259, 270

Bosch, Veerle Vanden 221, 238

Botton, Alain de 218-219, 259, 268

Boutens, P.C. 114

Brandt, Bettina 127, 129, 263, 269

Brassinga, Anneke 171, 181-182

Bremen, Geert van 93, 95, 261

Broeck, Raymond Van den $77-78,86,182$

Brogli, Simona 237, 260

Brône, Geert 141

Brosens, Koenraad 37

Brower, Reuben 85

Brown, Deborah 169, 181

Bruggen, Carry van 56, 61

Burgersdijk, L.A.J. 114

Burgess, Anthony 108-109, 119, 187

Buwalda, Peter 42, 45, 259

Buysse, Cyriel 160

Buysse, Maddy 160, 164-167, 259

Cairo, Edgar 113, 119

Campenhout, Laura van 241-247, 269

Cappelle, Wannes 112

Carabén, Armand 237, 259

Carroll, Lewis (Charles

Dodgson) 110-111, 119

Carroll, Noël 131, 141
Cash, Johnny 115

Catford, J.C. $80-82,85$

CEATL 235, 266

Celan, Paul 180-181, 259

Cervantes Saavedra, Miguel de $57-61,135,259,270$

Césaire, Aimé 199

Chandler, Raymond 138, 141

Chateaubriand, François-René de 40

Chiaro, Delia 131, 141

Chomsky, Noam 83

Cicero $77-78$

Claes, Paul 29, 37, 97, 103, 114, 143-149, 159, 167, 265

Clarac, Pierre 45

Claus, Hugo 124, 129, 148, 153, 159-162, 165-168, 259, 268

Cneut, Carll 227

Coenen, Frans 154, 167

Cognetti, Paolo 69, 259

Cohen, Sylvie 129, 262

Cohendy, Mireille 126, 129

Coillie, Jan Van 221, 238

Collège de France 203

Collins, Suzanne 233, 237, 259-260

Colmer, David 182

Coninck, Herman de 101, 103

Cormier, Monique 103

Cortázar, Julio 59, 61, 260, 270

Couturier, Maurice 141, 262

Couturier, Yvonne 141, 262

Cowper, William 172, 181, 260

Crugten, Alain Van 124, 129, 259

Cultuurloket 12

Cunin, Daniel 129

Dahl, Roald 230, 237, 260

Daisne, Johan 160

Dam, Cornelis Frans Adolf van $57,60,259$

Damsma, Harm 47, 63-69, 105-119, 207, 209, 259, 262, 263, 265

Dante Alighieri 154, 172 
Darbelnet, Jean 8o, 86

Davis, Lydia 114

DBNL 36, 167, 182

Debrabandere, Peter 247

Delabastita, Dirk 136-137, 141

Del Corral, Irene 134, 141

Delisle, Jean 102-103

De Roy van Zuydewijn, H.J. 114

Derrida, Jacques 56

Descartes, René 199, 201, 205, 208-209, 260, 266

Devoldere, Luc 160, 167

Deyssel, Lodewijk van 154

Diepenbrock, Alphons 154

Diesthemius, Petrus 198, 260

d'Hane-Scheltema, Marietje 145, 149, 262

D'Hertefelt, Margot 37

D'hulst, Lieven 7-8

Diamond, Neil 115

Dolet, Etienne 79

Doorslaer, Luc Van 86

Dorst, Aletta G. 103

Driessen, Hans 142, 262

Dryden, John 172-174, 180-181

Dunlop, Carol 61, 260

Duval, Jeanne 178

Dylan, Bob 114, 119, 260, 265

Eagleton, Terry 166-167

Eco, Umberto 41, 142, 263

Edogawa, Ranpo 90, 95, 260

Eeden, Frederik van 153-156, 159, $162,166-167,260,266,268$

Elsschot, Willem 11

Ensor, James 121

Es, Gijsbert van 59, 61, 262

Expertisecentrum Literair Vertalen (ELV) 8, 15, 18, 30-31,35

European Network for Literary Translation (ENLIT) 15

Fanon, Frantz 199, 202, 204-207, 209, 260

Fish, Stanley 133, 135, 141

Flaubert, Gustave 116

FOD Economie 12

Fontijn, Jan 154, 167

Foucault, Michel 199, 202-206, 208-209, 260, 266

Fournier, Guillaume 237, 260

Frank, Anne 22

Frank, Armin Paul 86, 141

Franzen, Jonathan 133-134, 141

Frauenfelder, Johan 115

Fredriksson, Marianne 251-252, 260
French, Albert 112, 119, 260

Freud, Adler 199

Freud, Anna 199

Freud, Sigmund 200

Frost, Robert 169

Gadda, Carlo Emilio 100

Gambier, Yves 86

García Lorca, Federico 98, 103

García Márquez, Gabriel 141

Gellings, Paul 103, 261

Gemert, Gerard van 226

Genette, Gérard 41

Gerbrandy, Piet 181

Gerritsen, Marinel 247

Gilliams, Maurice 153, 156, 158, $162,166-167,260$

Ginzburg, Natalia 122, 129, 260

Giphart, Emy 55-56, 61, 262

Glastra van Loon, Aline 142, 262

Godon, Ingrid 227

Goerlandt, Iannis 69, 263

Goethe, Johan Wolfgang von 183

Goffman, Erving 133, 141

Gräfe, Ursula 92, 95, 261

Graftdijk, Thomas 142, 262

Grass, Günter 161

Grave, Jaap 129, 160, 167

Greenall, Annjo 142

Greiner, Norbert 86,141

Grit, Diederik 87, 95, 99, 103

Groep Algemene Uitgeverijen (GAU) 12

Groot, Ger 206

Gross-Loh, Christine 219, 263, 268

Grunberg, Arnon 42, 268

Gruner, Charles R. 132, 141

Grutman, Rainier 123, 125, 129

Guène, Faïza 126, 234-235, 237-238, 260-261

Haan, Frans de 206, 209, 263

Haan, Martin de 123, 129, 177, 181, 209, 263

Hachmeister, Sylke 237-238, 259, 261

Hadewijch 59, 61, 261

Haeringen, Annemarie van 227

Hamburger, Michael 180-181, 259

Hannay, Mike 103

Harstad, Johan 49, 54, 69, 261

Haute, Luk Van 87-95, 260-263, 270

Hayashi, Fumiko 89, 95, 261

Hegel, Georg Wilhelm Friedrich 199

Heidegger, Martin 206
Heim, Michael Henry 161, 164-167, 259

Hendrickx, Ruud 247

Henkes, Robbert-Jan 63, 69, 114$115,119,181,198,259-261,265$

Hermans, Theo 85, 141

Hermans, Willem Frederik 160

Hertmans, Stefan 121, 124

Hertog, Erik 143

Hiëronymus $76,78,82$

Hild, Adelina 142

Hillenius, Dick 56, 61

Hillesum, Etty 125, 129, 261, 268

Hines, Barry 110, 119

Hiraide, Takashi 89, 95, 261

Hoekmeijer, Nicolette 47-54, 266

Hofstadter, Douglas 182

Hofstede, Rokus 123, 129, 263

Holierhoek, Jeanne 199-209, 260, 262, 266

Holmes, James S. 146, 149-170, 172-176, 180-181

Homerus 174

Hooft, P.C. 59, 61, 261

Hopman, Philip 227

Hopkins, Gerald Manley 56

Hugo, Daniel 124

Hugo, Victor 97

Hutcheon, Linda 133,141

Ichikawa, Takuji 93, 95, 261

Inoue, Yasushi 94-95, 261

Instituut voor de Nederlandse Taal (INT) 35

Jacobowitz, Seth 95, 260

Jakobson, Roman 74, 80-81, 85

James, Henry 217

Jansen, Hanne 142

Jansen, Theo A.J.M. 182

Janssens, Jacques 172

Jarmusch, Jim 169, 181

Johnson, Samuel 173, 182

Jones, Francis R. 179, 182

Jong, Inge de 119, 263

Jong, Martien J.G. de 156, 167

Jooken, Lieve 126, 129

Joyce, James 69, 114, 161, 184, 197, $261,265,267$

Kaas, Marianne 129

Kalla, Irena Barbara 221, 238

Kant, Immanuel 201

Kawabata, Yasunari 94-95, 261, 270

Kawakami, Hiromi 91, 95, 261

Kenny, Dorothy 86

Kiefer, Verena 238, 263

Kittel, Harald 86,141 
Klinkert-Pötters Vos, J.H. 122, 129,260

Kloos, Hans 182

Kloots, Hanne 126, 129

Klöss, Peter 237, 259

Koenders, Edith 49, 54, 69, 261

Kok, Marije 48

Koller, Werner 141

Komrij, Gerrit 188

Koolschijn, Gerard 58

Kopland, Rutger 101, 103, 261

Koster, Cees 7, 27, 85-86, 95, 182,259

Kosters, Onno 169-182, 267

Kowlier, Flip 112

Kousbroek, Rudy 25, 27

Kraus, Karl 194, 198, 261

Krone, Patty 63, 69, 259

Kuijer, Guus 230-231, 238, 261, 266

Kuijper, Jan 55, 59, 61, 261

Kundera, Milan 161

KVB Boekwerk 17

Laet, Eddy de 146, 149, 262

Lamartine, Alphonse de 40

Lamb, Charles 190, 198, 262

Lamb, Mary 190, 198, 262

Lambert, José 141

Landheer, Ronald 137, 141

Lanoye, Tom 121, 124

Larkin, Philip 170, 174, 176, 180

Lawrence, D.H. 205, 209, 262

Leal, Alice 86

Lebeau, Paul 157, 167

Leech, Geoffrey 153, 167

Lee-Jahnke, Hannelore 103

Lefevere, André 157-158, 167, 171, $175-176,178,180,182,260$

Lekens, Frank 114, 119, 262

Lemm, Robert 60

Lemmens, Marcel 103

Lemmens, Wendy 162, 168

Lennon, John 115

Lenoir, Frédéric 217, 219, 262

Lernout, Geert 184, 198

Leuven-Zwart, Kitty van 144, 149

Liddell, Alice 111

Lievois, Katrien 126, 129, 133, 141

Ligthart Schenk, Ingejan 198, 263

Lindo, Elvira 135, 138, 141

Lingen, Saskia van der 47, 54, 262

Linn, Stella 97-103, 267

Lira 14

Liszt, Franz 41, 108

Lodge, David 136-137, 141, 262
Logie, Ilse 127, 129

Lomré, Maurice 238, 261

Lowell, Robert 175

Mann, Thomas 100

Mannoni, Octave 205-206, 209

Marías, Javier 134-135, 142, 262, 270

Markin Powell, Allison 92, 95, 261

Marks, David F. 135, 142

Martín Lloret, Jordi 238, 261

Marx, Karl 201

Matsier, Nicolaas 110-111, 119

Mbembe, Achille 208-209, 262

McCartney, Paul 115

Meihuizen, Jan 145-146, 149, 262

Meijer, Caroline 27, 85-86, 95, 259

Melnick, David 175, 178, 182

Melville, Herman 55, 57, 61, 139-140, 142, 262, 270

Michiels, Ivo 160

Michiels, Shana 26-27

Middelbeek-Oortgiesen, Janny 249-252, 260, 267

Miedema, Niek 47, 63-69, 119, 262-263, 265

Milne, A.A. 111,119

Min, Neeltje Maria 55

Minne, Richard 22

Missinne, Lut 129, 161, 165, 167, 168

Mitchell, David 47-48, 110, 119, 262, 265

Moeyaert, Bart 236, 266

Molendijk, Arie 97, 102-103, 267

Mokeddem, Malika 126, 269

Montesquieu 200, 207, 266

Moody, Rick 107, 119

Mossop, Brian 247

Morris, Charles William 143, 149

Morris, Ivan 89, 95, 261

Mounin, Georges 80, 86

Mulisch, Harry 125-126, 129, 160,268

Multatuli 22, 59, 61, 262, 268

Munday, Jeremy 86

Murakami Haruki 89-90, 95, 262,270

Naaijkens, Ton 27, 39, 44-45, $85-86,95,103,179,181-182,259$

Nahed, Noureddine 126, 129

Nakayama-Ziegler, Kimiko 92, 95, 261

Neubert, Albrecht 86

Newmark, Peter 86

Nederlands Letterenfonds (NLF) $8,12,15,18,47,68,74$,
212, 223, 252, 253-257, 266-268, 271

Nida, Eugene $77,82-83,86$

Niemeyer, A.C. 59, 61, 261

Nietzsche, Friedrich 142, 262

Nijhoff, Martinus 59, 61, 182, 261

Nijmeijer, Peter 182

Nikiforidou, Kiki 138, 141

Noble, Philippe 39-45, 124-125, 129, 261, 263, 268-269

Noorduijn, Mirjam 221, 238

Noorman, Jelle 211-219, 259, 262-263, 268

Nooteboom, Cees 160, 167, 268-269

Norberg, Ulf 137, 142

Nord, Christiane 22, 27

O'Connell, Mark 217, 219, 262, 268

Onnes-de Groot, H.I. 198, 262

Oosterling, Henk 202

Op de Beeck, Griet 124

Ortega y Gasset, José 80

Ounanian, Arlette 45, 259

Ovidius Naso, Publius 143, 145 $146,148-149,173,181,262$

Oz, Amos 123-124, 129, 262

Pach, Hilde 123, 129, 262

Pammachius 78

Paris, Franco 153-168, 260, 268

Parks, Tim 135, 142, 161, 168

Parr, Tony 103

Paul, Fritz 141

Paz, Octavio 184,198

Peeters, Kris $197-198$

Perec, Georges 116-117, 119, 262

PETRA-E Network 19, 27, 39, 45,266

Pizzuto, Antonio 160

Plato 154, 199, 205

Poe, Edgar Allan 116

Poel, Chris Van de 7-8, 19-27, 29-37, 270

Pol, Barber van de 55-61, 259-26o, 262, 270

Pope, Alexander 174

Porter, Max 47, 54, 262

Postema, Maria 237, 259

Pound, Ezra 147-148, 177, 182, 265

Proust, Marcel 40, 43-45, 123, 129, 263, 268-269

Puett, Michael 214, 219, 263, 268

Pynchon, Thomas 50

Queneau, Raymond 25, 27, 136, 142,263

Raffel, Burton 172-173, 176, 179-180, 182 
Ramírez Tello, Pilar 237, 260

Refsum, Christian 136, 142

Règâhs, De 115

Renkema, Jan 247

Reprobel 14, 269

Reve, Gerard 145, 160

Rich, Nathaniel 53

Richardson, Joanna 178, 181, 259

Rilke, Rainer Maria 148, 179, 265

Robillot, Henri 237, 260

Rodenko, Paul 182

Romein-Verschoor, Annie 61

Rosselin, Isabelle 125, 129, 238, 261, 263

Rostand, Edmond 198, 263, 265

Rot, Jan 115, 119, 263

Rousseau, Jean-Jacques 40

Rovers, Daniël 69, 263

Saint-Rémy 157-158, 167, 260

Sallis, John 198

Sanders, Ewoud 21, 27, 37

Sánchez, María T. 86

Sanders, Mathijs 168

Santana López, Belén 134, 142

Santen, Fedde van 253-257, 271

Santen, Karina van 51-52, 54, 63, $69,259,263$

Sartre, Jean-Paul 200, 206, 209, 263

Saunders, George 69, 263, 265

Schaap, H.W.J. 209, 262

Schaapman, Karina 222

Schippers, K. 158, 167

Schleiermacher, Friedrich 79-80, 84-86

Schmidt, Annie M.G. 238

Schmit, F.J. 59, 61, 261

Schoentjes, Pierre 133, 141-142

Schutten, Jan Paul 231-232, 238, 263

Schyns, Désirée 45, 121-129, 263, 268-269

Schuurmans, Jitse 145

Scocchera, Giovanna 247

Segers, Winibert 143

Selland, Eric 95, 261

Senn, Fritz 184, 197

Serres, Michel 200, 266

Shakespeare, William 113-114, $119,137,141,146,190-191,198$, 262-263, 265

Shelley, Percy Bysshe 158, 168

Short, Mick 153, 167
Sijs, Nicoline van der 247

Simms, Karl 74, 77, 86

Simon, Paul 115

Sintobin, Tom 168

Skou-Hansen, Tage 160

Slager, Miel 100, 103, 267

Slauerhoff, J.J. 41, 45

Slocombe, Will 89, 95

Smeyers, Elies 124, 129

Smith, Ali 48, 50-52, 54, 263

Smith, Zadie 126

Snell-Hornby, Mary 83, 86

Sollie, André 229, 238, 263

Speelman, Dirk 27, 37

Spinoy, Erik 159-160, 168

Spit, Lize 124

Spoor, Laurens 193, 198, 263

St Aubyn, Edward 53, 266

Steenmeijer, Maarten 60, 166,

$$
\text { 168, 259, } 270
$$

Steenstra, Nanne 181

Sterck, Goedele De 221-238, 261, 263, 266

Stevens, Paula 49, 54, 69, 261

Stigen, Terje 160

Storm, Arie 168

Suetsugu, Elisabeth 92, 95, 261

Sundman, Per Olof 160

Swan, Susan 105, 119, 263

Swift, Graham 109, 119

Taalunie 8, 24, 27, 247

Taivalkoski-Shilov, Kristiina 142

Tanizaki, Jun'ichiro 89

Tawada, Yoko 127, 129, 263, 269

Tentije, Hans 179, 181

Tieck, Ludwig 58, 61, 259

Timmer, Charles B. $186,198,263$

Tiselius, Elisabet 142

Todorov, Tzvetan 41, 121, 128, 129

Toorn, Willem van 198, 263

Toury, Gideon 83-84, 86

Truyen, Fred 27, 37

Tsjechov, Anton 185-186, 198, 263

Tymoczko, Maria 133, 142

Universitaire Pers Leuven 8

Urland 185

Valentijn, Abraham 146

Valéry, Paul 148

Vandaele, Jeroen 131-142, 269-270

Van Dale Uitgevers 35

Vandenberghe, Katrien 208-209, 262

Veen, Herman van 232
Venuti, Lawrence $80,85-86$, 177-178, 182

Verhagen, Arie 153,167

Verheyde, Sylvie 98

Verhoef, Rien 119, 260

Verlaine, Paul 97

Verstegen, Peter 114

Vertalershuizen 18

Verwey, Albert 114, 154

Vigny, Alfred de 43

Vinay, Jean-Paul 80, 86

Vitalski 98

Vlaamse Auteursvereniging (VAV) 14

Vlaams Fonds voor de Letteren (VFL) 8, 12, 15, 18, 68, 74, 222, 251, 253-257, 269-270

Vos, Marjoleine de 60-61

Vosmaer, Martine 51-52, 54, 63, $69,259,263$

Vriesendorp, Huberte 237, 260

Wagenaar, Pyter 247

Wachter, Lieve De 37

Wallace, David Foster 69, 263

Warhol, Andy 105

Wehr, Elke 142, 262

Weisgerber, Jean 159, 168

Welsh, Irvine 108, 119

Weltens, Bert 103

Werumeus Buning, J.W.F. 57, 6o, 259

Westerbaen, Jacob 146

Westerdijk, S. 139-140, 142, 262

Weverbergh, Julien 159, 168

Wiel, Guido van der 119, 262

Wilamowitz-Moellendorff,

Ulrich 143,149

Wildschut, Mark 206

Willaert, Tom 27, 37

Willems, Ine 241-247, 271

Willemsen, August 172, 175, 179, 182

Wittgenstein, Ludwig 183

Woerden, Frans van 237, 260

Wood, James 50, 132, 142, 155, 168

Yamada, Isuzu 88

Young, Damon 217, 219, 263

Zeeman, Michaël 177, 182

Zukofsky 175,178

Zweig, Stefan 186, 198, 263 
Alles verandert altijd is een onmisbaar instrument voor de literair vertaler in opleiding en de beginnende en gevorderde professional bij het vertalen in en uit het Nederlands. Voor het eerst worden hier alle belangrijke aspecten van het literair vertalen helder en bevattelijk samengebracht: de zakelijke en financiële aspecten, de basiskennis en vaardigheden die deze activiteit veronderstelt, de algemene kernbegrippen en uitdagingen, het vertalen van de traditionele literaire genres, maar ook van kinder- en jeugdliteratuur, literaire non-fictie en filosofie, en de 'nazorg' in de vorm van revisie, marketing en promotie.

Het boek is een initiatief van het Expertisecentrum Literair Vertalen (ELV), en bevat bijdragen van 23 vertaalexperts (wetenschappers, opleiders en vertalers), onder eindredactie van Lieven D'hulst en Chris Van de Poel. Beiden zijn lid van het wetenschappelijk comité van het ELV, een partnerschap van de Taalunie, de $\mathrm{KU}$ Leuven en de Universiteit Utrecht, in samenwerking met het Nederlands Letterenfonds en het Vlaams Fonds voor de Letteren.

Lieven D'hulst is gewoon hoogleraar Franstalige letterkunde en vertaalwetenschap aan de Letterenfaculteit van de KU Leuven.

Chris Van de Poel is coördinator van de opleiding literair vertalen aan de Letterenfaculteit van de KU Leuven, campus Antwerpen. 